James E. Hatch Robert W. White

University of Western Ontario

\title{
Canadian Stocks, Bonds, Bills, and Inflation: 1950-1987
}

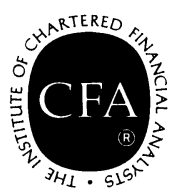

The Research Foundation of

The Institute of Chartered Financial Analysts 


\section{The Research Foundation of The Institute of Chartered Financial Analysts \\ Board of Trustees}

\author{
Chairman \\ James R. Vertin, CFA \\ Alpine Counselors \\ Vice Chairman \\ George W. Noyes, CFA \\ Standish, Ayer \& Wood \\ Research Director \\ Charles A. D'Ambrosio, CFA \\ University of Washington \\ President \\ Alfred C. Morley, CFA \\ The Institute of Chartered \\ Financial Analysts \\ Darwin M. Bayston, CFA \\ The Institute of Chartered \\ Financial Analysts
}

\author{
Thomas A. Bowman, CFA \\ The Institute of Chartered \\ Financial Analysts \\ Charles D. Ellis, CFA \\ Greenwich Associates \\ William F. Sharpe \\ Eugene C. Sit, CFA \\ Sit Investment Associates, Inc. \\ Walter P. Stern, CFA \\ Capital Research Co. \\ Donald L. Tuttle, CFA \\ Indiana University \\ James N. von Germeten, CFA \\ The Boston Company, Inc.
}

\section{Review Board}

Gerald O. Bierwag

University of Arizona

Charles A. D'Ambrosio, CFA

Research Director, RFICFA

Joanne M. Hill

Kidder Peabody \& Co. Inc.

\section{Editorial Staff}

Katrina F. Sherrerd

Assistant Vice President

Susan S. Brennan

Production Editor
Mark P. Kritzman, CFA

Windham Capital Management

Richard Roll

UCLA

Goldman, Sachs \& Co.

Gary G. Schlarbaum, CFA

Miller, Anderson \& Sherrerd

Ellen D. Goldlust Editorial Assistant

Diane B. Hamshar Administrative Assistant 
(C) 1988 The Research Foundation of the Institute of Chartered Financial Analysts

All rights reserved. No part of this publication may be reproduced, stored in a retrieval system, or transmitted, in any form or by any means, electronic, mechanical, photocopying, recording, or otherwise, without the prior written permission of the copyright holder.

This publication is designed to provide accurate and authoritative information in regard to the subject matter covered. It is sold with the understanding that the publisher is not engaged in rendering legal, accounting, or other professional service. If legal advice other expert assistance is required, the services of a competent professional should be sought.

From a Declaration of Principles jointly adopted by a Committee of the American Bar Association and a Committee of Publishers.

ISBN 10-digit: 0-943205-55-7 ISBN 13-digit: 978-0-943205-55-7

Printed in the United States of America 


\section{Mission}

The mission of the Research Foundation is to identify, fund and publish research material that:

- expands the body of relevant and useful knowledge available to practitioners;

- assists practitioners in understanding and applying this knowledge, and;

- enhances the investment management community's effectiveness in serving clients.

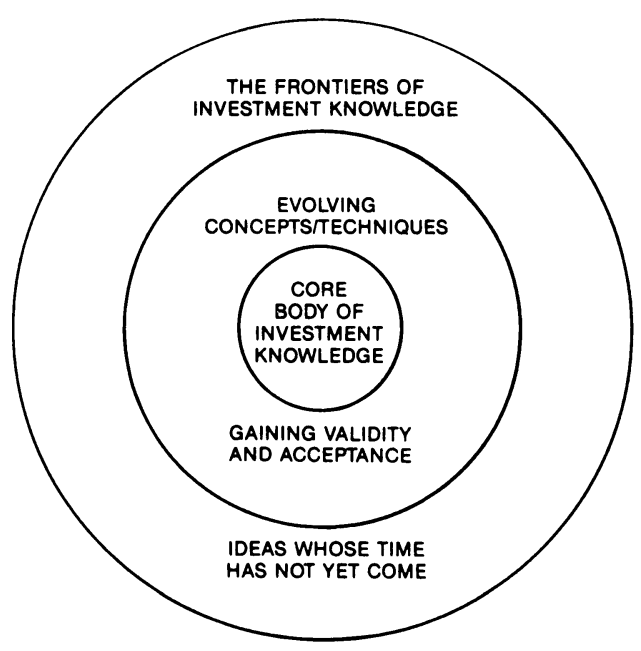

The Research Foundation of

The Institute of Chartered Financial Analysts P.O. Box 3665

Charlottesville, Virginia 22903 


\section{Table of Contents}

List of Tables $\ldots \ldots \ldots \ldots \ldots \ldots$ ix

List of Figures . . . . . . . . . . . . xv

Foreword $\ldots \ldots \ldots \ldots \ldots$. . . . . . . .

Acknowledgements . . . . . . . . . . . . xix

Chapter 1. Introduction and Summary .... 1

Chapter 2. The Canadian Capital Market. . . . . 15

Chapter 3. Taxation of Investment Income _. . 49

Chapter 4. Data Description and Sources . . . 67

Chapter 5. Data Presentation and Analysis _. . 85

Appendixes

Appendix A. Calculation of Treasury Bill Returns . . . . . . . . 201

Appendix B. Calculation of Long-Term

Government of Canada Bond Returns . . . . . . . . . 202

Appendix C. Calculation of Individual Stock Returns . . . . . . . . . 204

Appendix D. Calculation of Value-Weighted Total Return . . . . . . . . 2 210

Appendix E. Calculation of the Moving Standard Deviation . . . . . . . 215

Appendix F. Calculation of Real Returns . . . 216

Appendix G. Data Sources . . . . . . . . . 216

References. . . . . . . . . . . . . . 218 


\section{Tables}

Table 1-1 Characteristics of Selected Canadian and U.S. Annual Return Series for the Period January 1, 1950 -

December 31, 1987.

Table 1-2 Summary of Real Return, Inflation

Rate, Maturity Premiums, and

Default Premiums for Basic Return

Series Over the Period 1950-1987

Based on Geometric and Arithmetic

Annual Returns . . . . . . . . . . 12

Table 2-1 Distribution of Holdings of Selected

Government of Canada Debt

Instruments, 1952 to $1987 . \ldots . .20$

Table 2-2 Non-Government of Canada

Short-Term Paper Outstanding, 1961

to $1987 . \ldots \ldots \ldots \ldots$. . . . . 21

Table 2-3 Government of Canada Marketable

Bonds Outstanding, 1952 to 1987 . . 26

Table 2-4 Net New Bond Issues of Provincial and Municipal Governments, 1952 to $1987 \ldots \ldots \ldots \ldots$

Table 2-5 Net New Issues of Corporate Bonds, Preferred Stocks, and Common Stocks, 1961 to 1987 . . . . . . . 34

Table 2-6 Number of Shares and Dollar

Volume of Trading on the Toronto, Montreal, and Vancouver Stock

Exchanges, 1979 to 1987 . . . . . 39 


\section{Tables (continued)}

Table 3-1 Dividend Gross Up and Tax Credit System in Force, 1949 to $1986 . \quad$. . . 57

Table 5-1 Nominal Annual Returns for Basic Return Series, 1950 to 1987 . . . . 110

Table 5-2 Real Annual Returns for Basic Return Series, 1950 to 1987 . . . . 111

Table 5-3 Index of Nominal Wealth for Major Series, $1949=1.00,1950$ to $1987 \quad \ldots 112$

Table 5-4 Index of Real Wealth for Basic Return Series, $1949=1.00,1950$ to $1987 \ldots \ldots \ldots$. . . . . . . 113

Table 5-5 Treasury Bills: Total Returns; Rates of Return for Various Holding Periods from 1950 to 1987 . . . . . . 114

Table 5-6 Treasury Bills: Real Returns; Rates of Return for Various Holding Periods from 1950 to 1987 . . . . . 117

Table 5-7 Long Canada Bonds: Total Returns; Rates of Return for Various Holding Periods from 1950 to $1987 . \quad$. . . . . 120

Table 5-8 Long Canada Bonds: Real Returns; Rates of Return for Various Holding Periods from 1950 to 1987 . . . . . 123

Table 5-9 Provincial Bonds: Total Returns;

Rates of Return for Various Holding Periods from 1950 to 1987 . . . . . 126 


\section{Tables (Continued)}

Table 5-10 Provincial Bonds: Real Returns;

Rates of Return for Various Holding

Periods from 1950 to 1987 . . . . . 129

Table 5-11 Municipal Bonds: Total Returns;

Rates of Return for Various Holding

Periods from 1950 to 1987 . . . . . 132

Table 5-12 Municipal Bonds: Real Returns;

Rates of Return for Various Holding

Periods from 1950 to 1987 . . . . . 135

Table 5-13 Industrial Bonds: Total Returns;

Rates of Return for Various Holding

Periods from 1950 to 1987 . . . . . 138

Table 5-14 Industrial Bonds: Real Returns;

Rates of Return for Various Holding

Periods from 1950 to 1987 . . . . . 141

Table 5-15 Canadian Equities: Total Returns;

Rates of Return for Various Holding

Periods from 1950 to 1987 . . . . . . 144

Table 5-16 Canadian Equities: Real Returns;

Rates of Return for Various Holding

Periods from 1950 to 1987 . . . . . 147

Table 5-17 Consumer Price Index: Total

Returns; Rates of Return for Various

Holding Periods from 1950 to 1987. . 150

Table 5-18 U.S. CRSP Equities (Exchange Rate Adjusted): Total Returns; Rates of Return for Various Holding Periods from 1950 to 1986 . . . . . . . . 153 


\section{Tables (Continued)}

Table 5-19 Real U.S. CRSP Equities (Exchange Rate Adjusted): Total Returns; Rates of Return for Various Holding Periods from 1950 to 1986 . . . . 156

Table 5-20 Statistical Characteristics of Basic

Monthly Return Series for the Period 1950 to 1987 . . . . . . . 159

Table 5-21 Statistical Characteristics of Canadian and U.S. Monthly Return Series, 1950-1986. . . . . . . . . 160

Table 5-22 U.S. Monthly Return Series

(Ibbotson and Sinquefield), Exchange Rate Adjusted and Not Exchange Rate Adjusted, 1950 to $1986 \ldots \ldots \ldots 161$

Table 5-23 Correlations of Basic Monthly Return Series for the Period 1950 to 1987. . . . . . . . . . . . . . 162

Table 5-24 Correlations of Canadian and U.S. Monthly Return Series, 1950-1986 . 163

Table 5-25 Correlations of Canadian Returns in Month t with U.S. (Ibbotson and Sinquefield) Returns in Month t-1, Based on the Period 1950 to 1986 . 164 


\section{Tables (Continued)}

Table 5-26 Summary of Real Return, Inflation

Rate, Maturity Premiums and

Default Premiums for Basic Return

Series Over the Period 1950-1987

Based on Geometric and Arithmetic

Annual Returns . . . . . . . . . . 165

Table 5-27 Arithmetic Average Annual Return

Premiums, 1950 to 1986 . . . . . . 166

Table 5-28 Moving Standard Deviation of

Equity Returns, 12-Month Periods

1950-1987 . . . . . . . . . 167

Table 5-29 Summary Monthly Return Statistics

for the Large and Small Firm

Portfolios Using Value and Equal

Weighting, 1950101987 . . . . . 169

Table 5-30 Small Canadian Equities (Value

Weighted): Total Returns; Rates of

Return for Various Holding Periods

from 1950 to 1987 . . . . . . . 170

Table 5-31 Large Canadian Equities (Value

Weighted): Total Returns; Rates of

Return for Various Holding Periods

from 1950 to $1987 \ldots$. . . . . . 173

Table 5-32 Small Canadian Equities (Equal

Weighted): Total Returns; Rates of

Return for Various Holding Periods

from 1950 to $1987 \ldots$. . . . . . 176 


\section{Tables (Continued)}

Table 5-33 Large Canadian Equities (Equal Weighted): Total Returns; Rates of Return for Various Holding Periods from 1950 to 1987 . . . . . . . 179

Table 5-34 Market Sensitivities Regression Output Based on Log of Monthly Excess Returns, 1982 to 1987. . . . . 182

Table 5-35 Statistical Characteristics of the TSE 300 Subindexes for the Period February 1956 to December 1987 Employing Monthly Data . . . . . 194

Table 5-36 Betas and Related Characteristics of the TSE Price Subindexes Based on the 60 Months Ending December $31,1987 \ldots \ldots \ldots \ldots$

Table 5-37 Correlations Between the TSE 300

Subindexes Over the Period

February 1956-December 1987, Based on Monthly Data . . . . . 196

Table 5-38 Daily Closing Behavior of the TSE Price Index and the TSE Total Value Index During October $1987 . \quad \ldots$.

Table 5-39 Monthly Closing Behavior of the TSE 300 Price Index and the TSE 300 Total Value Index During 1987 and the First Two Months of $1988 \quad$. 199

Table 5-40 Percent Change of the TSE

Subindexes During Selected Days of 


\section{Figures}

Figure 1-1 Cumulative Wealth From a Dollar Invested in Equities, Treasury Bills, Industrial Bonds, and Federal Bonds As of December 31, 1949 Periods Ending 1950-1987 . . . . . . . . . 4

Figure 1-2 Cumulative Wealth From a Dollar Invested in a Portfolio of all Canadian Equities, Equities of Small Canadian Firms, Equities of Large Canadian Firms, and U.S. Equities as of December 31, 1949 Periods Ending 1950-1987 . . . . . . . . . 6

Figure 1-3 Cumulative Real Wealth From a

Dollar Invested in Equity, Treasury

Bills, Industrial Bonds, and

Federal Bonds as of December 31, 1949 Periods Ending 1950-1987 . . . 7

Figure 5-1 Frequency Distributions of

Canadian Equities, Industrial Bonds, and Treasury Bills Monthly Rates of Return ............ . 92 


\section{Foreword}

The Research Foundation of the Institute of Chartered Financial Analysts is committed to the task of identifying, funding, and publishing research that expands the body of knowledge available to practitioners. Stocks, Bonds, Bills, and Inflation - the United States edition by Roger Ibbotson and Rex Sinquefield and the Canadian edition by Jim Hatch and Bob White-exemplify this commitment. These studies provide the investment management community with information on historical returns and variability measures of several asset classes, as well as correlations among asset classes.

These information sources may be used to set investment policy, estimate future returns, and evaluate performance. As Robert Morrison pointed out in the Foreword to Canadian Stocks, Bonds, Bills, and Inflation: 1950-1983, the past data are important in the establishment of an investment policy for two reasons: the data provide a means of systematically determining the possible outcomes and implications of various investment policies and reviewing the past data may lead to a better understanding of the implications of a particular investment policy over time. Thus, returns, variability measures, and correlations are a powerful data for analysts, investment managers, and fund sponsors. The data also may be used to determine historical reference points, from which one may estimate future returns. Finally, the data provide the basis for performance evaluation relative to historical returns and to returns in other countries.

The Research Foundation takes great pride in publishing Canadian Stocks, Bonds, Bills, and Inflation: 1950-1987, a revision to the 1985 edition published by the Financial Analysts Research Foundation. This new publication 
updates the earlier study through 1987 and expands the number of issues represented in the database. For the benefit of investors who are not familiar with Canadian capital markets, the authors describe the operation of Canada's capital markets, with special emphasis on the types of securities traded, the trading mechanisms, and the factors which, over the past three decades, have influenced security returns. The authors also outline the tax environment in Canada.

The data in this study are already a valuable resource for investment professionals in Canada, they are destined to be important sources of information to investment professionals in other countries as the trend towards global investment continues. We are grateful to Dr. Hatch and Dr. White for their contribution to the body of knowledge.

Charles A. D'Ambrosio, CFA

Research Foundation of the Institute of Chartered Financial Analysts 


\section{Acknowledgements}

This study is the result of several years work in creating and "cleaning" the TSE/Western Database from which much of the empirical work is derived. We owe a debt of gratitude to John Grant at Wood Gundy and Peter Martin at McLeod, Young, Weir and Company who were early suppliers of data and advice. Since that time, many people at the Toronto Stock Exchange have made important contributions. Pearce Bunting, the late Huntly McKay, and Terry Popowich had the vision to support the concept of the TSE/Western Database; Marie-Josee Larocque, Steve Rider, Minique Lemky, John McDonald, and Mark VanRoon played major roles in its implementation. Innumberable months were spent at The University of Western Ontario, School of Business ensuring the accuracy and completion of the data. Much of this work was accomplished by students who have departed for careers in business and government. They include Barb Bramwell, Ben Butler, Jill Denham, Tom Hossfeld, Alex Kania, Craig MacKinlay, Maria Miele, Vince Ursini, Martin Osso, and Debbie Siess. The staff of the library at the School of Business including Elsie Brown, Jerry Mulcahy, Gail Begley, and Cheryl Jamieson were exceptionally cooperative and helpful in assisting us to track down missing data and complex intercorporate relationships.

Funding for the TSE/Western Database was provided by the University of Western Ontario, School of Business, Plan For Excellence and the Toronto Stock Exchange. The Research Foundation of the Institute of Chartered Financial Analysts (RFICFA) supplied a grant which enabled us to complete this work and sponsored its publication.

Several people at the RFICFA also helped in the production of the study. They were Charles D'Ambrosio, 
CFA, Katrina Sherrerd, Susan Brennan, Ellen Goldlust, Diane Hamshar, and Nina Hutchinson.

Typing of the manuscript at Western was completed by Linda Collins, Karen Katsiroumbas, and Connie Zrini. The interface with the Toronto Stock Exchange and the Financial Analysts Research Foundation was managed by Connie Zrini. 


\section{Introduction and Summary}

\section{INTRODUCTION}

In 1985, the Financial Analysts Research Foundation published Canadian Stocks, Bonds, Bills and Inflation: 1950-1983. This publication updates and expands that earlier monograph. The updating consists of adding data and a discussion of the tax environment pertaining to the years 1984-87. The expansion involves dramatically increasing the number of issues represented in the database and additional analyses such as a careful look at the October 1987 market crash and a discussion of the behavior of the major Toronto Stock Exchange (TSE) indexes.

This monograph addresses three key areas of concern to students of Canadian capital markets. First, the operation of Canada's capital markets is described, with special emphasis on the types of securities traded, the trading mechanisms, and the factors which, over the past three decades, have influenced security returns. This will benefit those unfamiliar with the Canadian capital market.

Second, because investors price securities with a view to obtaining reasonable risk-adjusted after-tax returns, the monograph outlines the tax environment in Canada from 1949-87. 
Third, the monograph describes the results of a thorough study of Canadian capital market returns over the period 1950-87 using portions of the TSE/Western Database. This database is located at The University of Western Ontario School of Business and has been developed jointly by the School of Business and the Toronto Stock Exchange. The study employs monthly total rate of return data for seven basic series: Treasury bills, Government of Canada long-term bonds, municipal bonds, provincial bonds, corporate bonds, equities, and the inflation rate. The Canadian equity monthly return series is derived from files containing monthly stock price, dividend, and outstanding share data for all TSE-listed equity securities during the 1975-87 period and for a significant subset of the most actively-traded securities over the 1950-74 period. The specific equity data set is described more fully in Chapter 4 .

The database also contains monthly return data for the United States over the period 1950-86 taken from Stocks, Bonds, Bills and Inflation: The Past and The Future, (Ibbotson and Sinquefield [14]), the subsequent publication of R.G. Ibbotson Associates, Inc. entitled Stocks, Bonds, Bills and Inflation: 1986 Yearbook [25] and the Center for Research in Security Prices (CRSP) Index. These U.S. return series include Treasury bills, U.S. Government long-term bonds, industrial bonds, equities, and the inflation rate. Additional U.S. equity return data for the period 1950-86 were obtained from data tapes supplied by CRSP. These data sources, as well as all computations, are described in detail in Chapter 4 and the Appendixes.

These basic return series were used to perform a variety of descriptive analyses, including the means and measures of variation for each return series in nominal and real terms; the cumulative nominal and real wealth from investment in each basic return series; annual return matrixes for all 
holding periods from $1950-87$ for all basic return series, and comparison of the statistical features of the Canadian and U.S. return series. The maturity and default premiums are measured for both the Canadian and U.S. series. This is followed by a discussion of the 12-month moving standard deviation of Canadian and U.S. equity returns. An analysis is made of the returns available (excluding transactions costs) from investing in small as opposed to large Canadian firms. Next, there is a discussion of the behavior of the TSE index, followed by an analysis of the impact of the October 1987 crash on security returns. Finally, betas are reported for a number of Canadian securities. The results of these data analyses are highlighted in the following section.

\section{SUMMARY OF RESULTS}

\section{Growth in Nominal Wealth}

Figure 1-1 shows how a dollar continuously invested since January 1, 1950, in equities, long-term Government of Canada bonds, long-term industrial bonds, or Treasury bills would have grown in value by December 31, 1987. For the purposes of this analysis, it is assumed that compounding takes place monthly, there are no transaction costs or taxes, and all dividends and interest are reinvested. This figure shows that the performance of equities has been far superior to that of fixed-income securities. Results for municipal, provincial, and industrial long-term bonds are quite similar to the results for the industrial and Government of Canada bonds. 


\section{FIGURE 1-1}

\section{CUMULATIVE WEALTH FROM A DOLLAR INVESTED IN EQUITIES, TREASURY BILLS, INDUSTRIAL BONDS, AND \\ FEDERAL BONDS AS OF DECEMBER 31, 1949 PERIODS ENDING 1950-1987}

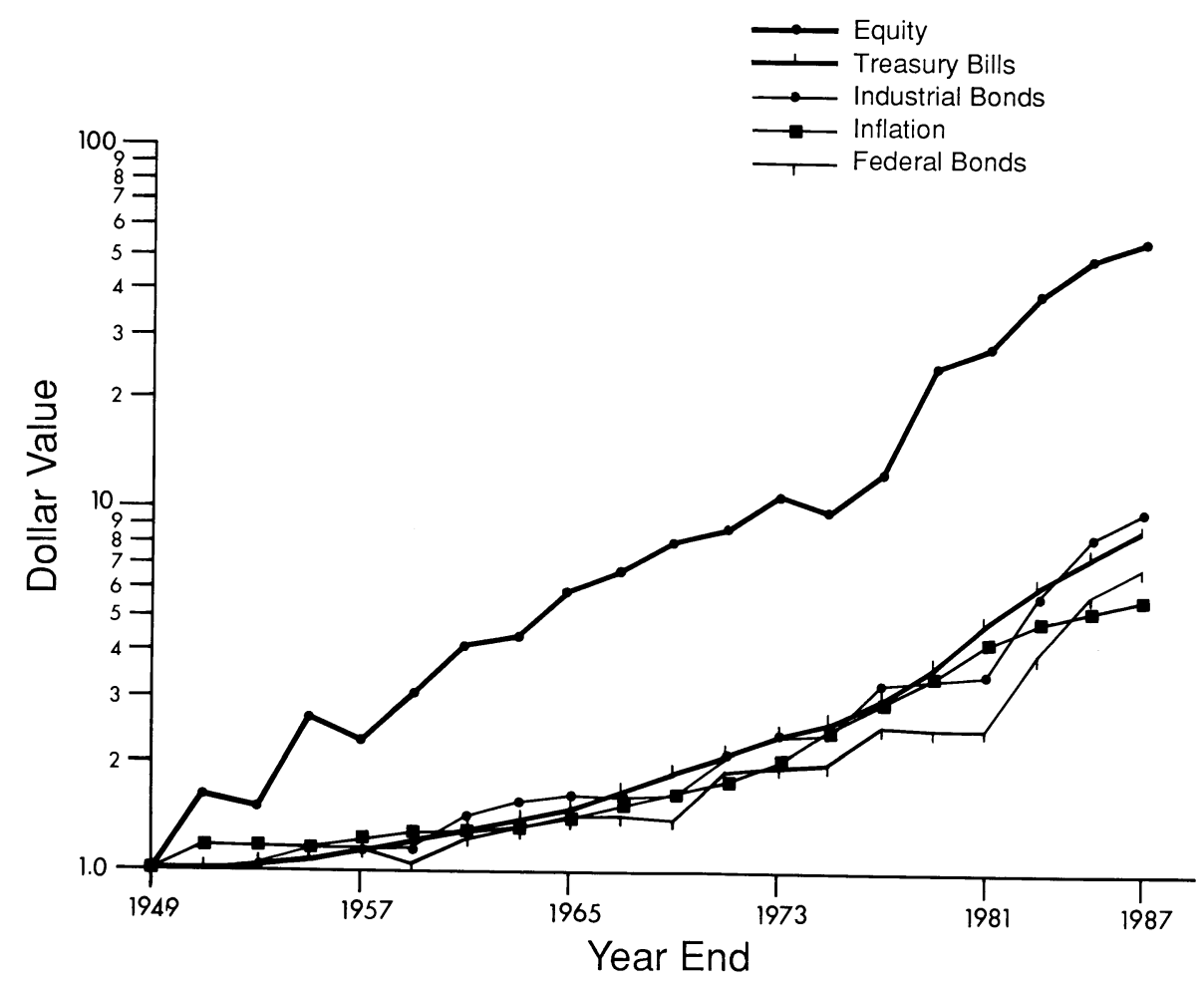




\section{Growth in Nominal Wealth Through}

\section{Equity Investment}

Figure $1-2$ is a similar analysis of cumulative wealth comparing Canadian equities with U.S. equities and with two subsamples of Canadian equities: small firms and large firms. The U.S. equity series is taken from the CRSP data file and consequently reflects New York Stock Exchange listed securities; however, the U.S. series was adjusted for changes in the value of the Canadian dollar to reflect the return available to a Canadian investing in the United States. The Canadian equity subsamples' returns were derived, first, by rank-ordering all firms from large to small based on the total dollar value of all outstanding shares for each firm and, second, by placing the top half of the group into the large firm category and the bottom half of the group into the small firm category. This process was repeated each year and the value-weighted return on each of these portfolios was observed.

The results in Figure 1-2 are somewhat surprising in that, for much of the period, the U.S. market provided greater wealth than the supposedly riskier Canadian market. The superiority of the return on the small-firm portfolio relative to the large-firm portfolio is dramatic and consistent with results already noted in the United States [14]. On the other hand, the standard deviation of monthly returns is substantially higher for the small firm portfolio than for the large firm portfolio, suggesting that this higher return may be partly attributed to higher risk.

\section{Growth in Real Wealth}

Figure 1-3 shows the growth in real wealth over the 1950-87 period from an investment of $\$ 1.00$ in Canadian equities, Government of Canada bonds, industrial bonds, or Treasury bills. The figure demonstrates that equities provided a substantial increase in real wealth, but the 


\section{FIGURE 1-2}

CUMULATIVE WEALTH FROM A DOLLAR INVESTED IN A PORTFOLIO OF ALL CANADIAN EQUITIES, EQUITIES OF SMALL CANADIAN FIRMS, EQUITIES OF LARGE CANADIAN FIRMS, AND U.S. EQUITIES AS OF DECEMBER 31, 1949 PERIODS ENDING 1950-1987

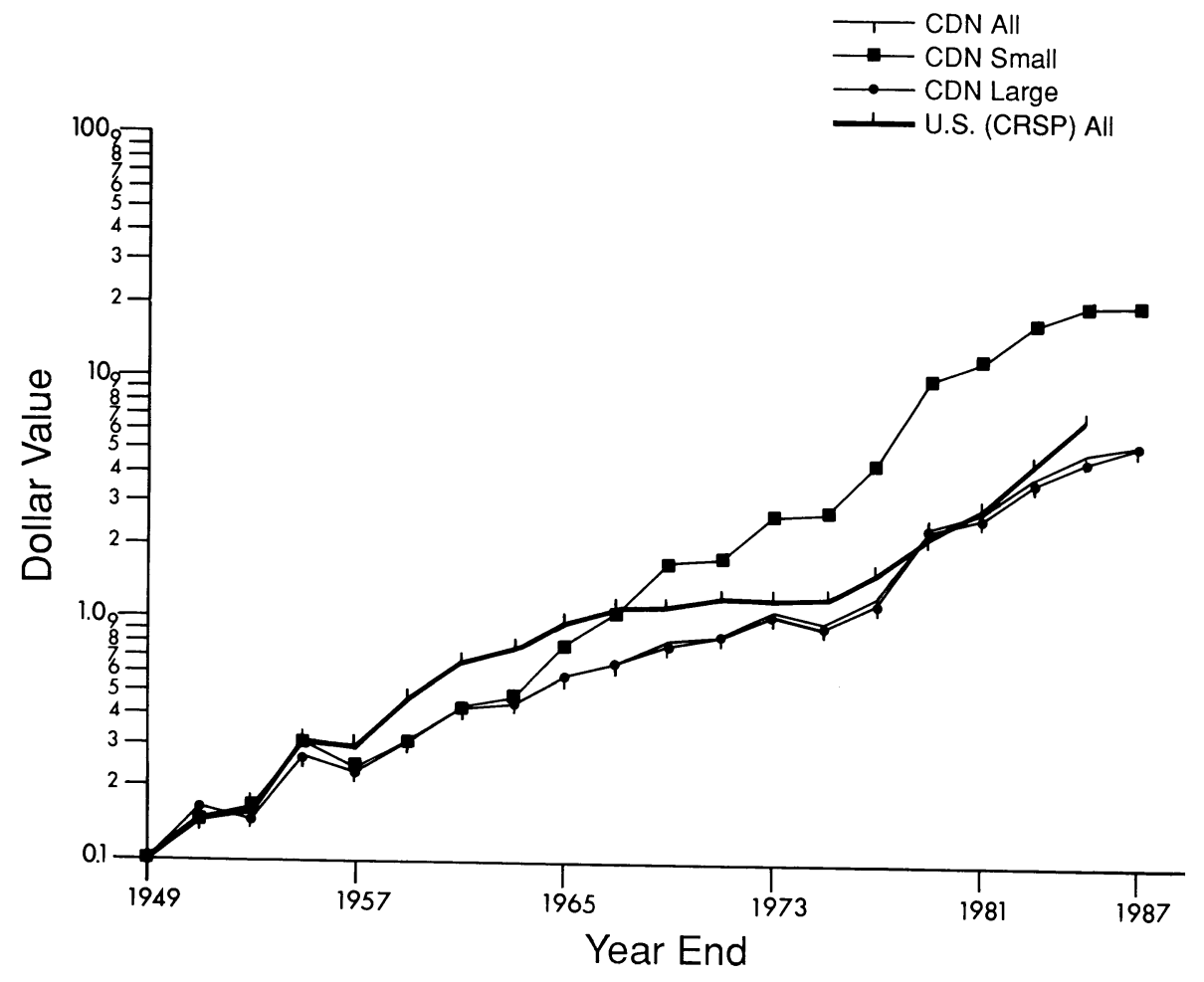


FIGURE 1-3

\section{CUMULATIVE REAL WEALTH FROM A DOLLAR INVESTED IN EQUITY, TREASURY BILLS, INDUSTRIAL BONDS, AND FEDERAL BONDS AS OF DECEMBER 31, 1949 PERIODS ENDING 1950-1987}

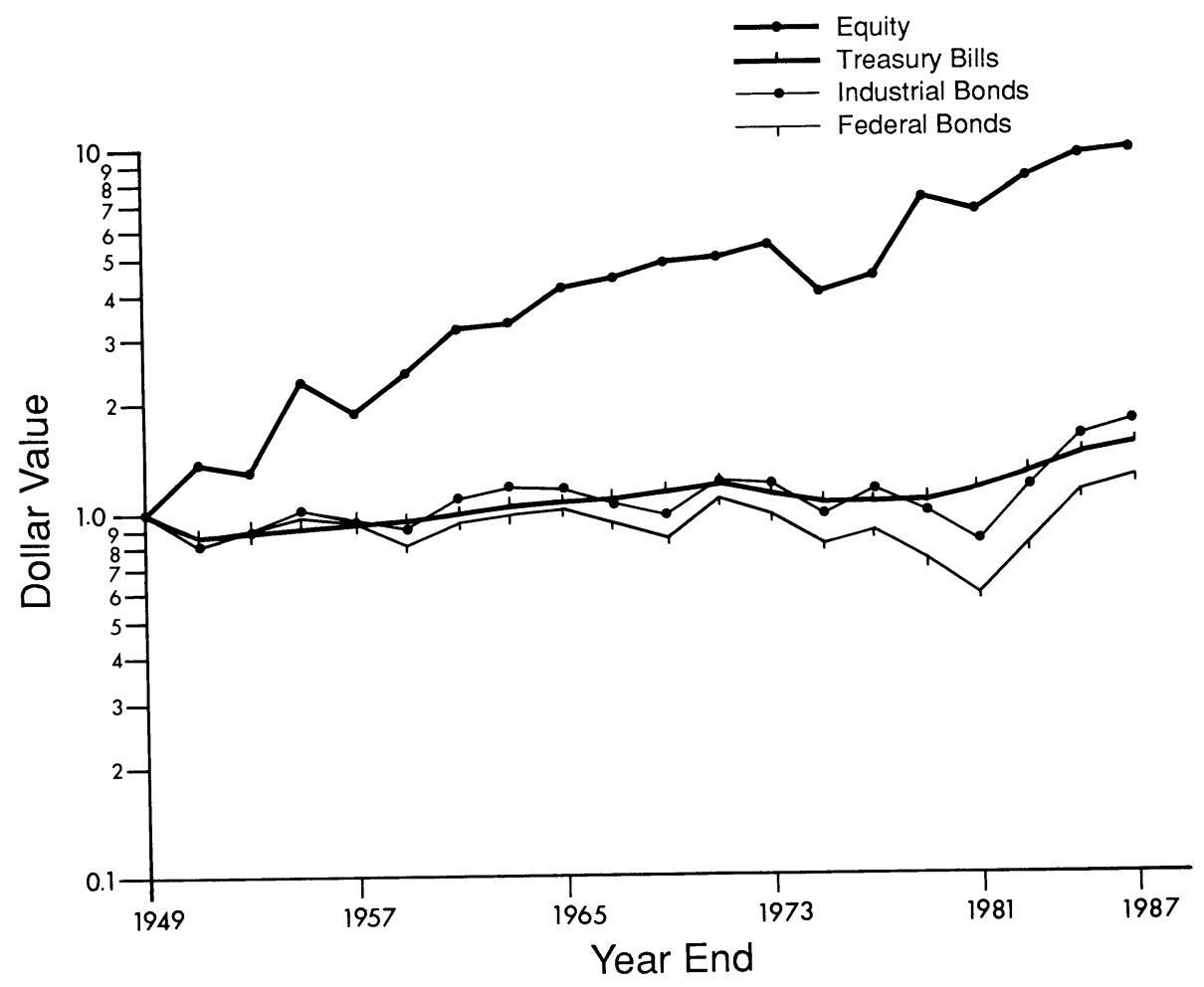


increase in real wealth from the fixed-income securities was small. If one assumes a reasonable (e.g., 25 percent) tax rate on the increase of nominal wealth, an investment in fixed-income securities would have led to a very modest increase in real wealth.

\section{Rates of Return}

Summary annual rate of return data for a variety of series covering the 1950-87 period are shown in Table 1-1. The geometric mean returns most accurately reflect the compound annual growth in wealth over the period, whereas the arithmetic returns provide the best estimate of the average return in any given year.

Within the Canadian series, it is apparent that equities exhibit the highest return. The rank ordering of returns from the fixed-income investments varies depending on whether one employs the geometric or arithmetic return measure. The relatively good performance of low-risk Treasury bills relative to long-term Government of Canada bonds is worth noting, however. As one would expect, the risk measures indicate higher risk for equities and lower risk for Treasury bills, with other investments falling in between.

As mentioned earlier, the sample of small Canadian firms provided a substantially higher equity return than the sample of large Canadian firms. This differential was most pronounced when the returns were equally weighted rather than value weighted.

Comparison of the Canadian and U.S. returns over the period 1950-86 shows that Canadian returns are higher for each category except equities. ${ }^{1}$ The variability of return is comparable in the two countries. The U.S. returns have been adjusted to reflect changes in the value of the Canadian

${ }^{1}$ At the time of writing, U.S. returns were not yet available beyond 1986. 


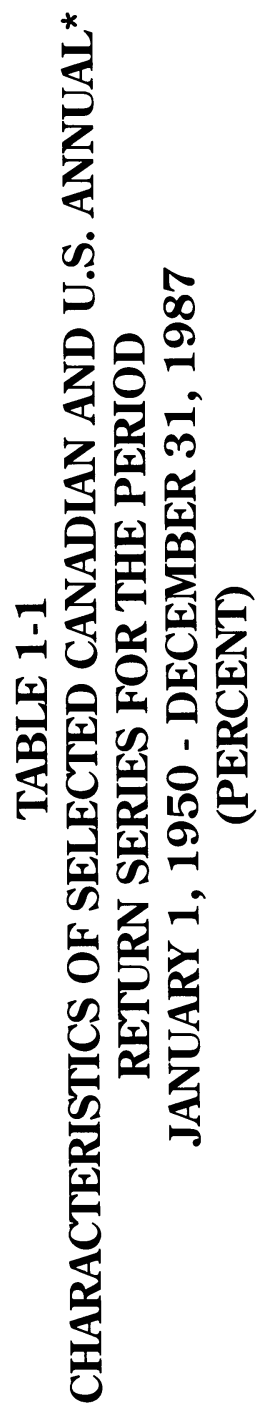

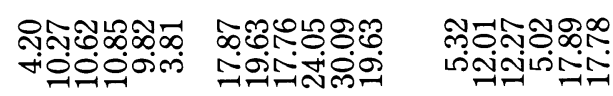

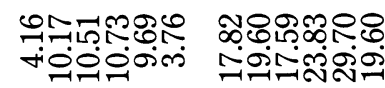

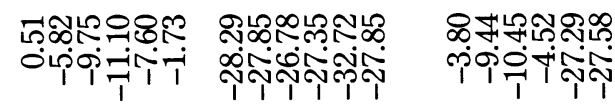

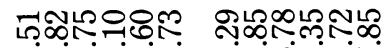

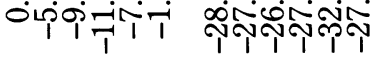

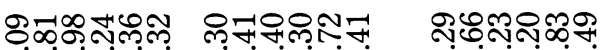

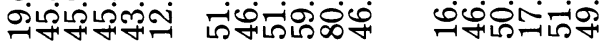

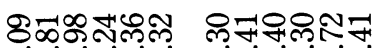

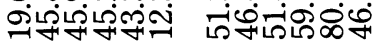

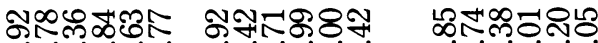

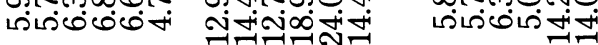

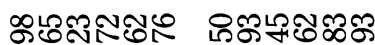

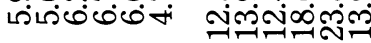

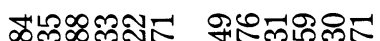

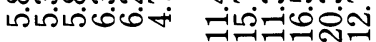

NAL5R5t

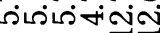

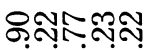

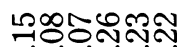

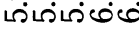

ปี่อี่อิ่า

政

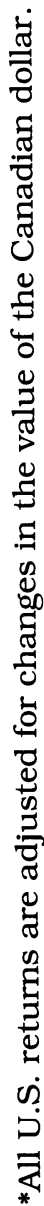

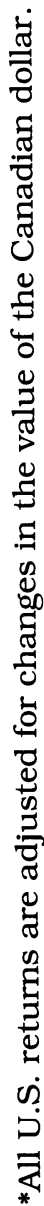

$\sum$

$\because \stackrel{\circ}{\theta}$

总

$\stackrel{\circ}{\circ}$
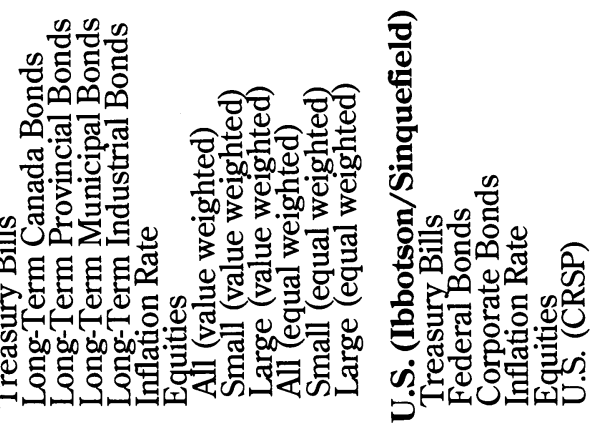
dollar, and therefore reflect the return earned by a Canadian investing in the U.S. market after adjusting for foreign exchange translation.

\section{Return Distributions}

A statistical analysis of the equity monthly return series showed that although returns were modestly skewed to the left and slightly peaked, their pattern was consistent with a normal distribution and was not consistent with a log-normal distribution. Fixed-income series returns were skewed to the right, had a high degree of kurtosis, and were not consistent with the normal distribution. Although several individual equity security series appeared to be normally distributed, many were not, and positive skewness was common. Positive skewness indicates that there is a greater chance of large positive returns than might be expected from a normal distribution. The economic explanation for this outcome is that equities offer the potential for large positive gains, but the maximum potential loss is limited.

\section{Correlation of Returns}

There was little serial correlation (correlation between this period's return and a previous period's return) in any of the series except for Treasury bills, which had a high degree of serial correlation.

The long-term bond series are all highly correlated but only modestly correlated $(0.27)$ with the equity return series. Treasury-bill returns are the only series that are highly correlated with the inflation rate. All Canadian return series exhibited a substantial correlation (e.g., 0.77 to 0.88 ) with their corresponding U.S. return series. U.S. returns were not a good monthly leading indicator of Canadian return series, however. In the case of Treasury bills, U.S. returns in period $\mathrm{t}-1$ were a modest leading indicator (correlation 0.35) for Canadian Treasury bills in period $t$. 


\section{Return Premiums}

It is common to think of security returns as consisting of a real return plus premiums for inflation, default risk, and maturity risk. Table 1-2 provides data on all of these premiums over the $1950-87$ period. Perhaps the only counterintuitive result is the apparently negative premium associated with term to maturity. These results are all quite comparable to those obtained with U.S. data.

\section{Moving Standard Deviation}

An interesting research question is whether the riskiness of the equity and debt markets has increased over time. To address this question, a 12-month moving standard deviation of equity returns was computed. The results suggest that in recent years, and particularly in the 1980-82 period and in 1987, return variability for both equities and debt securities has been higher than usual. Results for U.S. data were not as pronounced.

\section{Behavior of Subindexes}

An analysis was performed of the behavior of the 14 subindexes of the TSE 300. Since their inception, the highest return was earned by the Gold and Real Estate and Construction subindexes while the lowest return was earned by the Utilities subindex. As one might expect, the indexes recording the highest returns also tended to have the highest month-to-month variances in returns and the highest betas, although the relation was not perfect. The correlations among the subindexes were sufficiently low to promise substantial diversification by holding securities in more than one subindex. The most dramatic result was the virtually zero correlation between the Real Estate and Construction subindex and all other subindexes. 


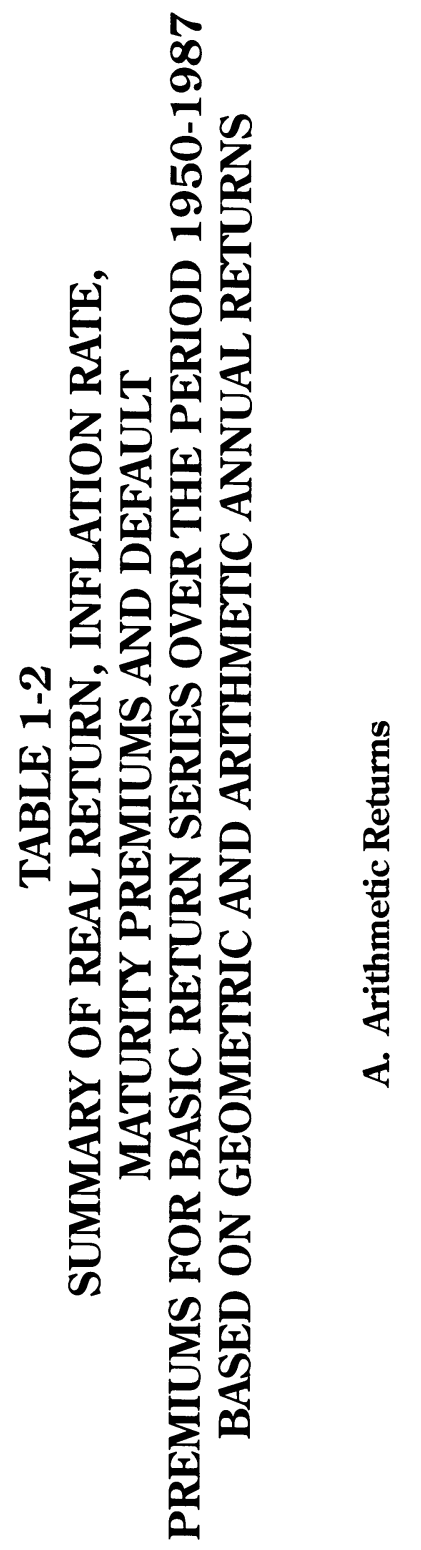

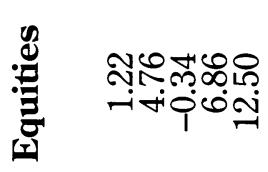

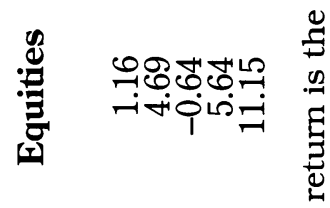

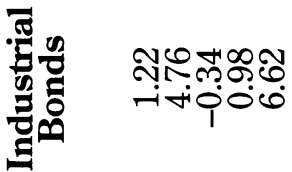

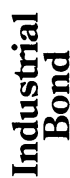

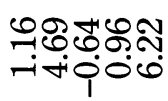

要

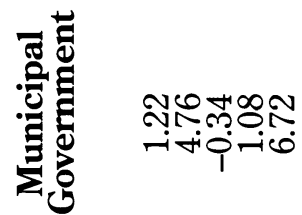

串苞苞

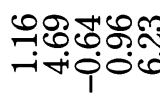

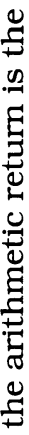

焉

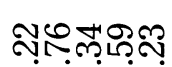

T+ípo

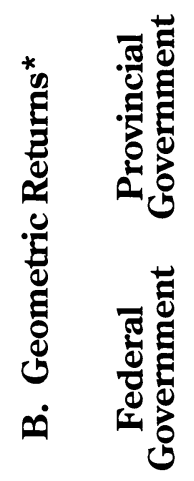

ใดูกิกิก

$\stackrel{\Xi}{\Xi}$

-ifipois

亏ें

E气

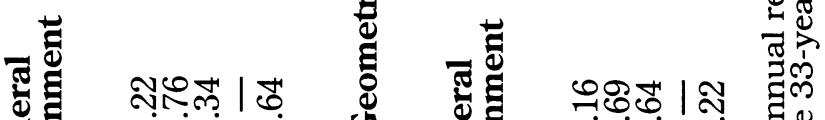

ifio

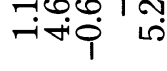

สิฐ

的

농

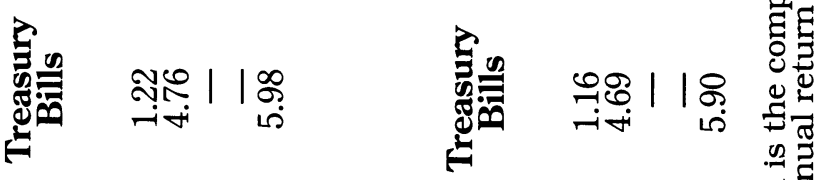

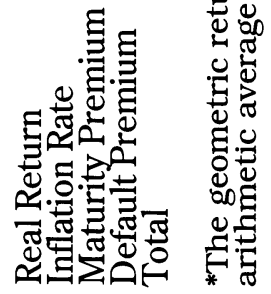




\section{The October Crash}

The TSE 300 price index fell 22.63 percent during the month of October 1987. While the market fell throughout the month the most severe impact was felt on Monday, October 19 (Black Monday) with a decline of 11.32 percent and the following day with a decline of 6.71 percent. The three industry groups most severely hit during the month were, Gold and Silver (-35.84 percent), Metals and Minerals (-30.62 percent) and Paper and Forest Products ( -29.34 percent). The group least severely affected was Utilities (-7.21 percent). 


\section{The Canadian Capital Market}

Many of the published studies of security returns devote a great deal of time to the discussion of statistics, but little time to explaining the marketplace from which the data were derived. This may lead to inappropriate inferences on the part of both the researcher and the reader. In the case of the U.S. market, a discussion of institutional arrangements is seldom necessary, because the capital markets are covered in a wide variety of other publications. In Canada, such information is not nearly as widely available. ${ }^{1}$ Consequently, we decided, for the benefit of both the Canadian and non-Canadian reader, to provide a descriptive overview of both the instruments and participants in the Canadian capital market. This section concludes with a discussion of the impact of such institutional developments on the interpretation of the returns data generated for this study.

\section{FIXED-INCOME SECURITIES}

It is common practice to divide the market for fixed-income securities into a money market and a bond market. The money market comprises the instruments, 
investors, borrowers, dealers, and institutional arrangements concerned with originating and trading short-term (one year or less) debt instruments. The bond market is concerned with debt instruments which have a remaining term to maturity in excess of one year. The one exception to this general definition is made by the Bank of Canada and certain dealers. The money and bond markets are closely related, having many of the same participants. Perhaps the most distinguishing features of the money market, in addition to the short term to maturity, are the generally high credit-worthiness of the borrowers and the high degree of marketability of the instruments.

\section{The Money Market}

Government of Canada Treasury Bills. The Canadian money market today is large and sophisticated, but is of relatively recent origin. Prior to 1934 , the only real money market securities were the Treasury bills issued sporadically by the Government of Canada. These bills, which had varying maturities, were purchased exclusively by the chartered banks which normally held them to maturity. ${ }^{2}$ Most chartered banks relied upon the New York call loan market for their liquidity needs.

The first Treasury bill auction took place in 1934 and biweekly auctions were introduced in 1937 . Stimulated by the need to finance World War II, the volume of Treasury bills outstanding increased throughout the early 1940s, but

\footnotetext{
${ }^{2}$ In the United States banks are classified as savings banks or commercial banks and may be incorporated under federal or state legislation. Branch banking is generally restricted, but these restrictions are gradually being removed. Commercial banks are permitted to take on trustee types of activities. In contrast, Canadian banks are federally chartered, have unlimited branch banking, and are not permitted to act as a trustee. Canadian trust companies take on a role similar to U.S savings banks, as well as conducting a wide range of estate, trust, and agency business.
} 
levelled off toward the end of that decade. Throughout this period, there was only a modest secondary market for bills, consisting of trades between chartered banks and the Bank of Canada. Although Treasury bills were used as an instrument of monetary policy by the central bank, they were not the primary vehicle for managing the liquidity needs of the chartered banks.

Beginning in 1953, the Canadian government took a variety of steps to create an active secondary market for money market instruments. Regular weekly auctions of three-month and nine-month bills were initiated. (In 1955 the auction of nine-month bills ceased, and in 1957 the government began to auction six-month bills.) The quantity of bills outstanding was also increased. To encourage dealers to hold inventories of securities, the Bank of Canada agreed to supply a limited number of dealers with purchase and resale privileges. Under this agreement, the Bank of Canada consented, if asked by the dealers, to purchase Government bonds, while at the same time agreeing to resell the securities to the dealers at a fixed price at some future date. The existence of such a purchase and resale facility encouraged dealers to carry an inventory, because the Bank of Canada always stood ready to purchase some of their excess holdings if required. In 1954, chartered banks began making day-to-day loans to selected dealers, which gave the dealers a major source of financing for their inventories of Government securities. Collateral for these loans took the form of the securities eligible for purchase and resale at the Bank of Canada. Finally, in late 1955, the chartered banks agreed to maintain a minimum level of secondary reserves to be held in the form of cash, day loans, and Treasury bills. As a result, the demand for Treasury bills began to grow at about the same rate as bank assets. 
All of the foregoing developments encouraged the growth of an active secondary market for Treasury bills. Investment dealers began to provide liquidity to market participants through their willingness to purchase and sell out of inventory. This ready market stimulated chartered banks to make greater use of Treasury bills to manage their liquidity, and encouraged other corporations to use Treasury bills as a vehicle for temporarily storing excess cash. Because this active secondary market did not begin until 1953, studies of Canadian money market returns typically use data beginning in the 1950s. As discussed in Chapter 4, this study utilizes Treasury bill return data beginning in January 1950.

Table 2-1 shows the dollar value and distribution of holdings of Treasury bills over the 1952-87 period. Initially, almost all bills were held within the banking system, but during the 1950s Treasury bills held by the general public (almost exclusively held by security dealers) increased dramatically. During the 1960s and early 1970s, chartered bank holdings of Treasury bills grew steadily, whereas public holdings languished. In the late 1970s and early 1980 s, however, public holdings of Treasury bills again became a major factor in the market. This time the investment dealers were joined by non-bank financial institutions, pension funds, and industrial corporations which provided a broadly based demand for this instrument. Some of this demand arose because investment dealers began offering "buybacks" to corporate customers similar to the buyback arrangements dealers had with the Bank of Canada. Under the buyback arrangement, dealers sold securities, such as Treasury bills, to corporations and agreed to buy them back at a fixed price at a particular future date. This arrangement allowed the corporate lender the opportunity to invest excess funds with a greater precision 
at higher yields than promised by chartered banks. Other major factors attracting the public sector to Treasury bills were the comparatively high rate of interest available, the greater level of sophistication of corporate cash managers, the comparatively poor performance of bond portfolios, and the introduction of a substantial number of money market mutual funds which proved attractive to the individual investor.

As of December 1987, Treasury bills, in bearer form only, were issued in denominations of $\$ 1,000, \$ 5,000, \$ 25,000$, $\$ 100,000$ and $\$ 1,000,000$ at a discount to mature at par. The quoted yield is computed as follows:

Yield $=\frac{100-\text { Price }}{\text { Price }} \times \frac{365 \times 100}{\text { term in days }}$

For those engaged in comparison between the U.S. and Canada, it is important to point out that the yield calculation for U.S. Treasury bills is based on a 360-day year. This means that quoted U.S. yields are systematically lower than Canadian yields. ${ }^{3}$

Short-Term Government Bonds. Table 2-1 shows the volume of outstanding Government of Canada bonds which have a maturity of three years or less. The nature of these and other Government of Canada bonds is discussed in detail in a subsequent section of this monograph.

Finance and Commercial Paper. A variety of short-term notes are issued by financial and nonfinancial corporations. Table 2-2 shows the dollar value of non-Government of Canada short-term paper, outstanding over the 1961-87 period. Beginning in the 1940s, finance companies began

\footnotetext{
${ }^{3}$ As an example of the size of this differential, a 91-day Canadian Treasury bill priced at 96 has a yield of 16.71 percent and the same U.S. Treasury bill has a yield of 16.48 percent.
} 
TABLE 2-1

DISTRIBUTION OF HOLDINGS OF SELECTED GOVERNMENT OF CANADA DEBT INSTRUMENTS

1952 to 1987 (\$ millions)

\begin{tabular}{|c|c|c|c|c|c|c|}
\hline \multirow[b]{2}{*}{$\begin{array}{l}\text { End of } \\
\text { Period } \\
\end{array}$} & \multirow[b]{2}{*}{$\begin{array}{l}\text { Bank of } \\
\text { Canada } \\
\end{array}$} & \multicolumn{4}{|c|}{ TREASURY BILLS } & \multirow{2}{*}{$\begin{array}{l}\text { BONDS } \\
3 \text { Years } \\
\text { and Under }\end{array}$} \\
\hline & & $\begin{array}{c}\text { Chartered } \\
\text { Banks }\end{array}$ & $\begin{array}{c}\text { Government } \\
\text { Accounts }\end{array}$ & $\begin{array}{l}\text { General } \\
\text { Public } \\
\end{array}$ & Total & \\
\hline 1952 & 283 & 139 & - & 28 & 450 & \\
\hline 1953 & 376 & 245 & 5 & 24 & $\begin{array}{l}450 \\
650\end{array}$ & \\
\hline 1954 & 169 & 363 & 41 & 208 & 780 & \\
\hline 1955 & 264 & 430 & 36 & 494 & 1,225 & 2,835 \\
\hline 1956 & 507 & 743 & 40 & 285 & 1,575 & 1,152 \\
\hline 1957 & 469 & 808 & 59 & 289 & 1,625 & 4,104 \\
\hline 1958 & 36 & 956 & 89 & 415 & 1,495 & 3,747 \\
\hline 1959 & 309 & 983 & 30 & 755 & 2,077 & 3,205 \\
\hline 1960 & 407 & 974 & 56 & 549 & 1,985 & 3,566 \\
\hline 1961 & 314 & 1,162 & 5 & 405 & 1.885 & 4.214 \\
\hline 1962 & 458 & 1,137 & 47 & 523 & 2,165 & $\begin{array}{l}4,214 \\
4,192\end{array}$ \\
\hline 1963 & 469 & 1,291 & 51 & 430 & 2,240 & 4.303 \\
\hline 1964 & 482 & 1,265 & 61 & 332 & 2,140 & 3,572 \\
\hline 1965 & 612 & 1,368 & 12 & 157 & 2,150 & 3,573 \\
\hline 1966 & 412 & 1,567 & 22 & 170 & 2,170 & 3,578 \\
\hline 1967 & 544 & 1,742 & 12 & 157 & 2,455 & 3,895 \\
\hline 1968 & 459 & 2,145 & 22 & 200 & 2,825 & 4,651 \\
\hline 1969 & 486 & 2,116 & 25 & 268 & 2,895 & 5,191 \\
\hline 1970 & 630 & 2,714 & 35 & 246 & 3,625 & 5,200 \\
\hline 1971 & 802 & 2,845 & 86 & 97 & 3,830 & 5,300 \\
\hline 1972 & 940 & 2,984 & 49 & 187 & 4,160 & 5,856 \\
\hline 1973 & 1,093 & 3,475 & 23 & 99 & 4,690 & 5,699 \\
\hline 1974 & 1,615 & 3,757 & 24 & 233 & 5,629 & 6,325 \\
\hline 1975 & 2,114 & 3,493 & 34 & 559 & 6,200 & 6,957 \\
\hline 1976 & 2,120 & 4,219 & 78 & 1,429 & 7,846 & 7,011 \\
\hline 1977 & 2,461 & 4,949 & 198 & 2,708 & 10,316 & 7,729 \\
\hline 1978 & 3,567 & 5,517 & 344 & 3,707 & 13,135 & 7,774 \\
\hline 1979 & 4,345 & 6,690 & 187 & 4,038 & 15,260 & 9,165 \\
\hline 1980 & 5,433 & 7,500 & 211 & 7,591 & 20,735 & 12,677 \\
\hline 1981 & 5,431 & 8,632 & 231 & 6,406 & 20,700 & 16,594 \\
\hline 1982 & 2,483 & 10,203 & 372 & 12,667 & 25,725 & 19,037 \\
\hline 1983 & 2,816 & 13,543 & 386 & 22,280 & 39,025 & 17,952 \\
\hline 1984 & 3,555 & 12,997 & 364 & 32,760 & 49,676 & 20,061 \\
\hline 198 & 4,060 & 12,629 & 354 & 42,357 & 59,400 & 19,744 \\
\hline 1986 & 7,967 & 15,161 & 252 & 46,319 & 69,700 & 23,956 \\
\hline 1987 & 9,847 & 11,503 & 235 & 52,617 & 74,202 & 26,701 \\
\hline
\end{tabular}

Source: Bank of Canada Review, various issues. 
TABLE 2-2

\section{NON-GOVERNMENT OF CANADA SHORT-TERM PAPER OUTSTANDING 1961 to 1987 (\$ millions)}

\begin{tabular}{|c|c|c|c|c|c|c|}
\hline Year & $\begin{array}{c}\text { Sales, } \\
\text { Finance } \\
\text { and } \\
\text { Consumer } \\
\text { Paper } \\
\end{array}$ & $\begin{array}{c}\text { Paper } \\
\text { Issued by } \\
\text { Other } \\
\text { Financial } \\
\text { Institutions }\end{array}$ & $\begin{array}{c}\text { Other } \\
\text { Commercial } \\
\text { Paper } \\
\end{array}$ & $\begin{array}{c}\text { Canadian } \\
\text { Dollar } \\
\text { Bankers' } \\
\text { Acceptances } \\
\end{array}$ & $\begin{array}{l}\text { Short-term } \\
\text { Paper of } \\
\text { Provincial } \\
\text { and } \\
\text { Municipal } \\
\text { Governments } \\
\text { and their } \\
\text { Enterprises } \\
\end{array}$ & Total \\
\hline 1961 & 491 & & 231 & 0 & & 722 \\
\hline 1962 & 635 & & 290 & 7 & & 931 \\
\hline 1963 & 801 & & 241 & 9 & & 1,051 \\
\hline 1964 & 1,060 & & 287 & 11 & & 1,358 \\
\hline 1965 & 842 & & 166 & 150 & & 1,158 \\
\hline 1966 & 927 & & 220 & 170 & & 1,137 \\
\hline 1967 & 912 & & 329 & 146 & & 1,386 \\
\hline 1968 & 1,219 & 167 & 187 & 116 & & 1,806 \\
\hline 1969 & 1,453 & 244 & 416 & 174 & 469 & 2,756 \\
\hline 1970 & 1,442 & 313 & 583 & 395 & 482 & 3,215 \\
\hline 1971 & 1,434 & 230 & 930 & 403 & 519 & 3,516 \\
\hline 1972 & 1,807 & 352 & 661 & 390 & 578 & 3,788 \\
\hline 1973 & 2,477 & 706 & 522 & 342 & 507 & 4,554 \\
\hline 1974 & 2,961 & 1,529 & 1,437 & 903 & 398 & 7,228 \\
\hline 1975 & 3,017 & 1,553 & 1,507 & 1,047 & 668 & 7,792 \\
\hline 1976 & 3,167 & 2,213 & 1,767 & 1,135 & 609 & 8,89 \\
\hline 1977 & 3,314 & 2,944 & 1,650 & 1,166 & 466 & 9,540 \\
\hline 1978 & 3,879 & 4,320 & 1,472 & 1,664 & 666 & 12,001 \\
\hline 1979 & 3,879 & 6,425 & 1,706 & 2,935 & 541 & 15,486 \\
\hline 1000 & 3,551 & 9,332 & 1,869 & 5,365 & 1,177 & 21,294 \\
\hline 19 & 3,501 & 6,793 & 2,521 & 6,561 & 1,347 & 21,443 \\
\hline I. & 1,821 & 5,341 & 2,355 & 12,666 & 3,903 & 26,08 \\
\hline & 2,372 & 6,673 & 3,106 & 13,858 & 5,297 & 31,306 \\
\hline & 2,975 & 7,104 & 3,986 & 13,606 & 6,950 & 34,621 \\
\hline & 4,049 & 6,189 & 3,790 & 17,593 & 7,418 & 39,039 \\
\hline 19 & 6,10 & 6,435 & 3,636 & 24,896 & 9,930 & 50,99 \\
\hline 198 & 7,335 & 7,393 & 4,465 & 31,457 & 11,119 & 61,769 \\
\hline
\end{tabular}

Source: Bank of Canada Review, various issues. 
to raise funds through notes for the purpose of extending credit to individuals to purchase items such as machinery, appliances, automobiles, and housing. For a number of years, finance paper represented the major investment alternative to government notes.

The rapid development of the market for Treasury bills after 1953 led to greater use of the money market by corporate borrowers. By the late 1950s, grain dealers and other nonfinancial corporations began to issue sizable numbers of short-term notes as an alternative to traditional short-term bank loans. These notes were attractive to borrowers because the interest rate was often lower than that available at banks. Lenders were willing to purchase these notes, because short-term interest rates were higher than those available on short-term bank deposits and Treasury bills.

When Atlantic Acceptance, a major finance company, defaulted on its liabilities in 1965, investor confidence was shaken, and the volume of finance paper issued temporarily plateaued. In 1967, the development of the secondary market in non-Government of Canada issues was aided by the introduction of "special" call loans to investment dealers. These were very short-term loans (same-day notice) similar to day loans made by chartered banks to money market dealers. They differed from day loans in that permitted collateral was expanded to include commercial and finance paper, provincial securities, and selected other short-term securities. As dealer inventories of paper grew, the demand for overnight financing increased, and the need was frequently met in part by loans from non-bank financial institutions, major corporations, and provincial agencies. These sources are called "offstreet financing."

The special call loan rate is significant among all short-term interest rates because it reflects current credit 
conditions. If banks have excess reserves, they tend to lower the rate charged on these loans to put their reserve imbalance to work on a temporary basis. This low-cost source of financing encourages dealers to borrow, using the proceeds to invest in other money market securities-an activity which lowers the yields on all money market instruments.

Bank Deposits. In response to the competition from governments, finance companies, and corporations for short-term funds, chartered banks began introducing a variety of new deposit instruments in the early 1960s. These deposit instruments had negotiated rates for a wide variety of fixed terms and were in bearer form. Issuance of these deposit instruments increased after the 1967 revision of the Bank Act, which removed the 6 percent ceiling on bank lending rates. By 1972 the chartered banks, faced with strong loan demand, were competing aggressively for funds. This forced commercial paper rates up and lowered the volume of such paper issued. To relieve some of this pressure, the Bank of Canada and the chartered banks agreed in 1972 to set a ceiling on the rates offered by chartered banks on large short-term deposit instruments. This became known as the Winnipeg Agreement and remained in effect until January 1975.

Canadian chartered banks also offer "swapped deposits," which are deposits made in a foreign capital market. The deposit is accepted in Canadian funds and is converted into a foreign (usually U.S.) currency deposit. Simultaneously, the bank arranges to convert the proceeds of the foreign currency deposit into Canadian dollars at a specified exchange rate on a specific future date. The result is a deposit bearing the foreign exchange hedging costs of the swap. These deposits are nontransferable and are for 
periods of one to six months. This lack of marketability makes them less desirable for investors.

Bankers'Acceptances. A banker's acceptance is a draft or promise to pay issued by a corporation and subsequently accepted or guaranteed by a chartered bank. An acceptance normally arises in the course of the sale of goods and, consequently, has a term to maturity of less than one year-most commonly 30 days. Bankers' acceptances are issued at a discount to mature at par and priced in the same manner as Treasury bills. The corporation pays a stamping fee to the bank ranging from 0.375 to 1.25 percent per annum, depending on competitive conditions. Because of the bank guarantee, the yield on acceptances tends to be lower than on commercial paper but higher than on Treasury bills. For high quality corporate borrowers, bankers' acceptances are considered to be an alternative to commercial paper, with the preferred vehicle depending on relative yields, stamping fees, and the cost of the standby line of credit associated with commercial paper issues.

The first bankers' acceptances were issued in 1962 and initially were largely held by investment dealers who were able to make a profit by financing their purchase through day loans. Growth in the market was slow until 1965, when the failure of Atlantic Acceptance caused several commercial and finance paper issuers to substitute bankers' acceptances. This switch also coincided with the lowering of stamping fees from 1.25 to 0.75 percent. From 1966 to 1969 there was no further growth. In 1969, the Bank of Canada limited the amount of day loan money that could be used by dealers to inventory acceptances. This led to higher yields on acceptances which, combined with tight money in 1969 and 1970, expanded the acceptance market to a broader base of borrowers and lenders. During the 1970 s, the bankers' acceptance market grew steadily as the 
banks began allowing clients to use this borrowing device in more innovative ways. By December 1980, the new Bank Act was able to remove the eligibility of bankers' acceptances as collateral for day loans without affecting the volume of business in this market which continues to grow in importance.

Affiliates of Foreign Banks. Beginning in the early 1970s, activity by the affiliates of foreign banks grew rapidly. These firms raise most of their funds in the money market by issuing notes which are usually guaranteed by their parent banks. The funds are then loaned to Canadian businesses.

Provincial and Municipal Governments. Because of the long-term nature of their commitments, provincial and municipal governments do most of their borrowing in the form of long-term debt issues. Short-term needs to accommodate such phenomena as seasonal tax collections are largely met through bank loans. All of the provinces, directly or through their agencies, and many of the larger municipalities, have tapped the short-term paper market, however. This paper is generally viewed as high quality and is available for a variety of terms and amounts.

\section{The Bond Market}

Government of Canada Bonds. Government of Canada bonds are issued at a price close to par value with a fixed annual interest rate payable semiannually. As market interest-rate conditions vary, the prices of these bonds fluctuate around par. The bonds are issued with original terms to maturity of 1 to 41 years, with an average remaining term to maturity of outstanding bonds (not including Treasury bills) at the end of 1986 at about 8.5 years. Table 2-3 shows the dollar value of outstanding Government of Canada marketable bond issues over the 1953-87 period. With a few exceptions, these bonds are typically 
TABLE 2-3

GOVERNMENT OF CANADA MARKETABLE BONDS OUTSTANDING

1952 to 1987 (\$ millions)

\begin{tabular}{|c|c|c|c|c|c|}
\hline Year & $\begin{array}{l}\text { Bank of } \\
\text { Canada }\end{array}$ & $\begin{array}{l}\text { Chartered } \\
\text { Banks }\end{array}$ & $\begin{array}{l}\text { General } \\
\text { Public }\end{array}$ & $\begin{array}{c}\text { Government } \\
\text { Accounts }\end{array}$ & Total \\
\hline 1952 & 1,988 & 2,767 & 7,631 & 1,101 & 13,487 \\
\hline 1953 & 1,946 & 2,617 & 7,483 & 1,309 & 13,355 \\
\hline 1954 & 2,098 & 2,003 & 6,331 & 1,163 & 12,595 \\
\hline 1955 & 2,151 & 2,694 & 6,042 & 1,455 & 12,342 \\
\hline 1956 & 1,919 & 1,781 & 5,940 & 1,478 & 11,118 \\
\hline 1957 & 1,994 & 1,883 & 5,756 & 1,308 & 10,891 \\
\hline 1958 & 2,634 & 2,565 & 5,658 & 1,170 & 12,207 \\
\hline 1959 & 2,368 & 1,827 & 6,758 & 893 & 11,846 \\
\hline 1960 & 2,337 & 2,084 & 6,937 & 810 & 12,168 \\
\hline 1961 & 2,563 & 2,631 & 6,838 & 640 & 12,672 \\
\hline 1962 & 2,478 & 2,234 & 7,329 & 623 & 12,664 \\
\hline 1963 & 2,622 & 2,642 & 7,173 & 465 & 12,902 \\
\hline 1964 & 2,633 & 2,439 & 7,199 & 708 & 12,979 \\
\hline 1965 & 2,860 & 2,355 & 6,906 & 544 & 12,665 \\
\hline 1966 & 3,061 & 2,324 & 6,641 & 826 & 12,852 \\
\hline 1967 & 3,263 & 2,888 & 6,284 & 802 & 13,237 \\
\hline 1968 & 3,483 & 3,429 & 6,498 & 963 & 14,373 \\
\hline 1969 & 3,627 & 2,977 & 6,713 & 1,008 & 14,325 \\
\hline 1970 & 3,665 & 3,889 & 6,198 & 971 & 14,723 \\
\hline 1971 & 3,972 & 4,608 & 5,433 & 518 & 14,531 \\
\hline 1972 & 4,512 & 4,148 & 5,379 & 562 & 14,601 \\
\hline 1973 & 4,931 & 3,816 & 4,989 & 585 & 14,321 \\
\hline 1974 & 5,423 & 4,364 & 4,702 & 656 & 15,145 \\
\hline 1975 & 5,766 & 4,278 & 5,134 & 707 & 15,885 \\
\hline 1976 & 6,333 & 4,424 & 6,186 & 774 & 17,717 \\
\hline 1977 & 7,844 & 4,587 & 8,308 & 867 & 21,606 \\
\hline 1978 & 8,479 & 4,303 & 13,901 & 845 & 27,528 \\
\hline 1979 & 9,409 & 3,378 & 21,507 & 720 & 35,014 \\
\hline 1980 & 10,660 & 2,451 & 28,331 & 764 & 42,206 \\
\hline 1981 & 11,787 & 1,593 & 32,521 & 901 & 46,802 \\
\hline 1982 & 13,059 & 1,673 & 36,936 & 1,089 & 52,757 \\
\hline 1983 & 14,367 & 2,958 & 41,010 & 1,255 & 59,590 \\
\hline 1984 & 13,756 & 2,128 & 53,543 & 1,360 & 70,787 \\
\hline & 11,746 & 2,357 & 71,246 & 1,655 & 87,004 \\
\hline 1986 & 10,455 & 2,180 & 87,344 & 2,351 & 102,330 \\
\hline & 10,565 & 3,387 & 95,960 & 3,442 & 113,354 \\
\hline
\end{tabular}

Source: Bank of Canada Review, various issues. 
non-callable and are subject to neither sinking funds nor purchase funds. A substantial number of issues are extendible at the option of the lender. Most issues are payable in Canadian currency, although issues have been made in U.S. dollars, Swiss francs, Deutsche marks, and Japanese yen.

The Bank of Canada acts as fiscal agent for the Government of Canada. Primary issue of bonds takes place through a large group of agencies including the Canadian chartered banks and major investment dealers, which receive a commission for their efforts. During the distribution period, primary distributors are not permitted to sell the bonds to investors below the issue price. The Bank of Canada generally is prepared to acquire all unsold bonds. New bond issues normally take place on the dates that old issues expire. The new issue is usually a package of several maturities such as a three-year, a five-year, and a twenty-five-year maturity. The total amount raised at any one time may vary from $\$ 500$ million to $\$ 1,500$ million.

In recent years, the federal government has increasingly sold its bonds by auction. Maturities in the range of two to five years have been auctioned regularly, and one issue with a maturity of seven years was also auctioned. Whether the government will eventually adopt the auction process for all of its long-term debt remains to be seen.

Government of Canada marketable bonds have a long history, beginning almost at the time of Confederation as the new government began to refund outstanding provincial obligations. Initially, government borrowing was modest and heavily dependent on the sterling market. Beginning with World War I, outstanding debt increased dramatically but then stabilized until the beginning of World War II. During this period, the capability of the domestic market to absorb the debt gradually expanded. During World War II, 
there was another dramatic increase in the volume of outstanding debt (from $\$ 1.5$ billion in 1939 to $\$ 15$ billion in 1945). These funds were raised in the domestic market through 11 different issues, most of which were long term. In the period following World War II, the volume of outstanding debt declined as new issues took place primarily to refund maturing debt. By 1958, the government had decided to increase outstanding debt but was faced with a large volume of wartime bonds maturing over the 1958-66 period. To facilitate future debt issues, the government decided to convert 90 percent of the outstanding issues into four new issues, which were to mature over the 1961-83 period. The result was a lengthening of the average maturity of the national debt from seven years to almost twelve years by September 30 , 1958. This action has come to be known as the Conversion Loan Program. One of the issues, the $4.5 \mathrm{~s}$ of 1983 , became known as a bellwether issue because of its large size and ready marketability. During the 1960s, much of the net new government borrowing took place through the increasingly popular Canada Savings Bonds and the expansion of the Treasury bill market. As a result, most long-term bonds were issued for refunding purposes and the average maturity of the debt declined again.

During the early 1970s, the debt of the Government of Canada grew at a moderate pace, but from 1975 to 1987 outstanding debt grew more quickly. This expansion in outstanding debt was achieved by increasing both the frequency and size of new issues, and by making greater use of the long-term end of the market. At the end of 1973, for example, bonds with 10 years or more to maturity made up only 12 percent of all marketable bonds (excluding Treasury bills). By December 1983, this had grown to 37 percent and by 1987 had declined to 29 percent. This 
increased volume of available long-term bonds made the bond market more liquid, but may have caused the average spread between government and corporate bonds to narrow.

Government of Canada bonds are held by a variety of investors, including chartered banks, the Bank of Canada, and the public. A breakdown of holdings by segments is shown in Table 2-3.

Provincial and Municipal Bonds. Provincial governments are responsible for such activities as health services, education, and highways. Funds to meet these needs are derived from provincial income taxes, sales taxes, and transfer payments from the federal government. The provinces also own a variety of enterprises such as hydro, transportation, and telephone companies. Municipal governments obtain revenues primarily from property taxes and transfer payments from other levels of government, and use these funds to meet such local needs as roads, waterworks, and sanitation.

Provincial governments issue marketable debt instruments in Canada and abroad. They also raise funds directly by placing nonmarketable securities with the Canada Pension Plan and various provincial accounts. Municipal governments issue some public debt and place other issues with provincial government agencies. Net new provincial and municipal financing over the $1952-87$ period is displayed in Table 2-4.

Because most of the needs of provincial and municipal governments and their enterprises are long term, these governments have emphasized the long end of the bond market. Most municipalities issue their debt in Canada, whereas the provinces have made substantial use of foreign capital markets. Use of foreign rather than domestic markets depends on the domestic availability of appropriate 
TABLE 2-4

NET NEW BOND ISSUES OF PROVINCIAL AND

MUNICIPAL GOVERNMENT

1952 to 1987

(par value, $\$$ millions)

\begin{tabular}{|c|c|c|c|c|c|c|}
\hline \multirow[b]{2}{*}{ Year } & \multicolumn{3}{|c|}{ PROVINCIAL $^{a}$} & \multicolumn{3}{|c|}{ MUNICIPAL $^{\mathbf{b}}$} \\
\hline & Canada & Abroad & Total & Canada & Abroad & Total \\
\hline 1952 & 253 & 58 & 311 & 108 & 41 & 149 \\
\hline 1953 & 160 & 112 & 272 & 126 & 56 & 182 \\
\hline 1954 & 247 & 47 & 294 & 222 & 18 & 240 \\
\hline 1955 & 261 & (50) & 211 & 217 & 17 & 234 \\
\hline 1956 & 348 & 192 & 540 & 135 & 89 & 224 \\
\hline 1957 & 504 & 44 & 548 & 176 & 103 & 279 \\
\hline 1958 & 438 & 153 & 591 & 199 & 149 & 348 \\
\hline 1959 & 327 & 239 & 566 & 218 & 84 & 302 \\
\hline 1960 & 462 & 17 & 479 & 277 & 89 & 366 \\
\hline $1961^{\mathrm{c}}$ & 933 & 5 & 938 & 337 & (20) & 317 \\
\hline 1962 & 598 & 98 & 696 & 223 & 20 & 243 \\
\hline 1963 & 610 & 283 & 893 & 300 & 2 & 302 \\
\hline 1964 & 584 & 356 & 940 & 285 & 115 & 400 \\
\hline 1965 & 512 & 246 & 758 & 226 & 21 & 247 \\
\hline 1966 & 1,211 & 355 & 1,566 & 280 & 69 & 349 \\
\hline 1967 & 1,359 & 690 & 2,049 & 358 & 108 & 466 \\
\hline 1968 & 1,114 & 832 & 1,946 & 224 & 73 & 297 \\
\hline 1969 & 974 & 975 & 1,949 & 193 & 45 & 238 \\
\hline 1970 & 1,681 & 385 & 2,066 & 265 & (26) & 239 \\
\hline 1971 & 2,246 & 324 & 2,570 & 366 & (50) & 316 \\
\hline 1972 & 2,046 & 843 & 2,889 & 332 & 70 & 402 \\
\hline 1973 & 2,101 & 573 & 2,674 & 370 & 28 & 398 \\
\hline 1974 & 2,321 & 1,441 & 3,762 & 393 & 149 & 542 \\
\hline 1975 & 3,911 & 2,924 & 6,835 & 632 & 466 & 1,098 \\
\hline 1976 & 4,719 & 4,631 & 9,350 & 539 & 697 & 1,237 \\
\hline 1977 & 4,744 & 2,724 & 7,468 & 922 & 280 & 1,201 \\
\hline 1978 & 5,537 & 1,658 & 7,195 & 704 & (49) & 656 \\
\hline 1979 & 5,274 & 1,606 & 6,880 & 697 & (110) & 587 \\
\hline 1980 & 8,474 & 305 & 8,779 & 613 & (174) & 439 \\
\hline 1981 & 7,641 & 5,282 & 12,923 & 259 & 102 & 361 \\
\hline 1982 & 9,295 & 5,365 & 14,659 & 517 & 460 & 977 \\
\hline 1983 & 8,580 & 3,904 & 12,484 & 498 & 267 & 765 \\
\hline 1984 & 8,249 & 2,736 & 10,985 & 375 & 662 & 1,037 \\
\hline 1985 & 6,920 & 2,902 & 9,822 & 216 & 333 & 549 \\
\hline
\end{tabular}




\section{TABLE 2-4 (Continued)}

\begin{tabular}{cccccccc} 
& \multicolumn{3}{c}{ PROVINCIAL $^{\mathbf{a}}$} & & \multicolumn{3}{c}{ MUNICIPAL $^{\mathbf{b}}$} \\
\cline { 2 - 3 } Year & Canada & Abroad & Total & & Canada & Abroad & Total \\
1986 & 8,069 & 6,361 & 14,430 & & 452 & 464 & 917 \\
1987 & 4,396 & 2,389 & 6,785 & & 598 & 145 & 743
\end{tabular}

Note: Net values exclude payments into sinking funds.

a. Provincial bonds include issues purchased by provincial accounts and with Quebec Pension Plan Funds.

b. Municipal bonds do not include issues guaranteed by the provinces (which are already included in provincial bonds) and issues sold directly to the provinces.

c. Includes \$104 million bonds guaranteed by Province of British Columbia which were issued in exchange for preferred stock of B.C. Electric.

Source: Bank of Canada Review, various issues. 
maturities and issue sizes, as well as the relative costs of financing. Combined provincial and municipal debt issues doubled during the $1960 \mathrm{~s}$, spurred by rapid economic growth and greater government financing needs. A good portion of these needs was met by the Canada Pension Plan and the Quebec Pension Plan. These plans, introduced in 1965 , provided that any funds available after taking care of plan needs could be loaned to the provinces in proportion to the plan contributions from those provinces. These nonmarketable loans normally had a 20-year term and a yield equal to the Government of Canada rate at the time of issue. Because Canadian interest rates were higher than foreign rates throughout the $1960 \mathrm{~s}$, foreign borrowing grew dramatically in both absolute and relative terms. By 1969, foreign loans represented over 40 percent of all provincial financing, and the provinces were expanding their horizons beyond the United States to Europe. Many of these foreign issues were for larger amounts and longer terms than domestic issues. In fact, because of the general unwillingness of lenders to provide longer maturities, many of the new issues in the late 1960s and 1970s were made extendible or retractable.

Prior to 1970 , the value of the Canadian dollar was fixed relative to the U.S. dollar. In 1970, the value of the Canadian dollar was allowed to float in response to market forces. It soon began to rise in price relative to the currency of its major trading partners. Consequently, the Canadian government asked the provinces to consider placing their issues in the domestic market rather than offshore, to keep the Canadian dollar from rising further. Although this action lessened the level of foreign borrowing for a time, the major activities of government enterprises, such as the James Bay Hydroelectric Project, soon expanded the need for both foreign and domestic borrowing. In the latter half 
of the 1970s, the need for provincial financing declined at the same time that two new sources of funds came to be utilized: direct international placement of loans through bank syndicates, and the "heritage funds" of some of the western provinces built up through energy taxes. The bank loans were typically floating-rate, seven- to ten-year loans arranged in the Eurodollar market.

With the approach of the 1980s, provincial borrowing rose dramatically. This increased borrowing was attributable to large capital expenditure programs and deficits run by most of the provinces to combat the recession. To meet these growing needs, the provinces continued to borrow from a broad range of countries and to issue securities with a variety of maturities.

Corporate Bonds. Canadian corporations regularly issue bonds in both the Canadian and foreign capital markets. These bonds may represent public offerings underwritten by an investment dealer or they may be privately placed. Table 2-5 shows the net new issues of bonds by Canadian financial and nonfinancial corporations over the 1961-87 period.

Although the volume of new corporate bond issues has generally increased over the past decade, its overall significance relative to the level of government financing has changed dramatically from one period to another. For example, in 1972 net new debt issues by the three levels of government were $\$ 4.6$ billion relative to corporate issues of $\$ 1.6$ billion, a ratio of 2.8 times. By 1982 , governments were carrying large deficits and corporations were facing a recession. During that year, net new issues by the three levels of government had risen to $\$ 29.6$ billion, whereas corporate issues had increased to $\$ 4.5$ billion, a ratio of 6.3 times. By 1986, there had been a number of years of economic growth and corporations began to enter the bond 
TABLE 2-5

NET NEW ISSUES OF CORPORATE BONDS, PREFERRED STOCKS, AND COMMON STOCKS

1961 to 1987

(\$ millions)

\begin{tabular}{|c|c|c|c|c|c|c|c|c|}
\hline \multicolumn{7}{|c|}{ Corporate Bonds } & \multicolumn{2}{|c|}{ Equity } \\
\hline & & & No & cial ( & 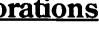 & & & \\
\hline In Canada & Abroad & Total & In Canada & Abroad & Total & $\begin{array}{l}\text { Total } \\
\text { Bonds }\end{array}$ & $\begin{array}{l}\text { Preferred } \\
\text { Stock } \\
\end{array}$ & $\begin{array}{c}\text { Common } \\
\text { Stock }\end{array}$ \\
\hline & & & & & & 369 & (65) & 294 \\
\hline & & & & & & 443 & 64 & 257 \\
\hline & & & & & & 691 & 49 & (96) \\
\hline 185 & 36 & 221 & 388 & 177 & 566 & 787 & 38 & 269 \\
\hline 274 & 12 & 286 & 639 & 410 & 1,049 & 1,335 & 149 & 289 \\
\hline 30 & 82 & 112 & 375 & 485 & 859 & 972 & 177 & 388 \\
\hline 96 & (8) & 88 & 604 & 162 & 766 & 854 & 180 & 269 \\
\hline 29 & 28 & 57 & 393 & 270 & 663 & 720 & 122 & 435 \\
\hline 83 & 16 & 99 & 369 & 366 & 735 & 834 & 143 & 851 \\
\hline 157 & (1) & 155 & 978 & 364 & 1,342 & 1,497 & 101 & 250 \\
\hline 401 & (48) & 353 & 1,389 & 96 & 1,485 & 1,839 & 111 & 230 \\
\hline 647 & 71 & 717 & 954 & 0 & 954 & 1,672 & 199 & 417 \\
\hline 822 & (1) & 821 & 800 & (5) & 795 & 1,617 & 89 & 509 \\
\hline 544 & 70 & 614 & 1,091 & 178 & 1,269 & 1,884 & 453 & 279 \\
\hline 396 & 290 & 687 & 1,823 & 316 & 2,139 & 2,826 & 710 & 547 \\
\hline 211 & 1,451 & 1,662 & 986 & 1,343 & 2,329 & 3,991 & 684 & 591 \\
\hline 778 & 628 & 1,407 & 2,325 & 1,368 & 3,693 & 5,100 & 2,445 & 698 \\
\hline 933 & 479 & 1,413 & 2,260 & 1,014 & 3,274 & 4,687 & 5,726 & 1,097 \\
\hline 807 & 808 & 1,615 & 393 & 748 & 1,140 & 2,755 & 1,648 & 2,873 \\
\hline 418 & 1,119 & 1,538 & 1,095 & 1,125 & 2,220 & 3,758 & 2,580 & 2,812 \\
\hline 748 & 1,300 & 2,049 & 831 & 3,115 & 3,952 & 6,001 & 4,224 & 2,916 \\
\hline (492) & 1,274 & 783 & 567 & 3,134 & 3,700 & 4,483 & 2,922 & 3,758 \\
\hline (294) & 1,000 & 706 & 749 & 976 & 1,725 & 2,431 & 2,310 & 7,508 \\
\hline (75) & 682 & 606 & 457 & 881 & 1,339 & 1,945 & 4,732 & 4,430 \\
\hline 311 & 2,847 & 3,158 & 1,030 & 1,342 & 2,372 & 5,530 & 5,776 & 6,114 \\
\hline 1,528 & 6,591 & 8,119 & 2,083 & 2,194 & 4,277 & 12,396 & 4,095 & 10,045 \\
\hline 340 & 3,227 & 3,568 & 3,092 & 2,700 & 5,792 & 9,360 & 3,079 & 9,324 \\
\hline
\end{tabular}

Source: Bank of Canada Review, various issues. 
market in greater numbers. Net new issues of government securities in 1986 amounted to $\$ 24.6$ billion and new issues by corporations $\$ 13.3$ billion, a ratio of 1.8 times. ${ }^{4}$

The need for funds by corporations depends on their level of investment in fixed plant and equipment, as well as in working capital items such as accounts receivable and inventories. A substantial amount of this need is normally met through the retention of profits, but there is usually a significant shortfall which is met through borrowing, the issue of new equity, or drawing down excess liquid balances. Regarding debt, corporations have three broad choices: to borrow from a financial institution such as a bank, to issue short-term notes, or to issue long-term debt instruments. It is this issue of long-term debt that is noted in Table 2-5. Corporations have tended to follow a pattern of increasing their short-term borrowing (money market and bank loans) substantially during periods of rapid economic growth. Then, when the economy slows somewhat, much of the short-term debt is replaced by long-term debt issues. The increase in long-term debt issues in 1975 is partly attributed to this phenomenon. A related reason for increased long-term debt issues is interest-rate expectations. Continually rising interest rates through the 1970s led many corporate treasurers to borrow in the short end of the market. In 1977, long-term rates temporarily declined, causing many corporations to increase long-term debt to build up their liquidity positions and pay off current liabilities. Other phenomena may affect the level of debt issues as well. For example, in 1981 there was a large increase in takeover activity in Canada, partly as a result of the National Energy Program. Much of this activity was financed through long-term debt issues.

${ }^{4}$ Bank of Canada Review, December 1986, pp. S84-S86. 
Long-term debt issues may take place in the Canadian or foreign markets. Although a number of factors influence this choice, the primary factor is the relative level of interest rates in Canada and abroad. The year 1976 provides a good example of a heavy move toward foreign borrowing when interest rates in other countries were substantially lower than those in Canada.

In contrast with the Government bonds discussed earlier, corporate bonds may have a wide range of features. Corporate bonds may be backed by a specific collateral security (mortgage bonds), or by the general earning power of the business (debentures); they may even have a subordinated position to other creditors (subordinated debentures). Bonds may be repayable at maturity or may involve gradual repayment (serial bonds, sinking fund bonds). More and more frequently, corporate bonds provide an option to the lender which permits modification of the term to maturity (extendible, retractable) or receipt of repayment in some form other than straight interest or principal payments (convertible). The types of features popular at any given time depend a great deal on current economic conditions and the tax environment. For example, in 1978 a high proportion of corporate debt issues took the form of income debentures. These debentures were issued because they represented a low after-tax cost of funds for certain types of corporations. The tax advantage was expected to be eliminated in the November 1978 budget, however, so there was a last flurry of this type of security issued in that year.

Two factors present themselves when attempting to measure available returns from corporate bonds. First, the wide variety of features of individual bonds makes comparison between bond issues quite difficult. Second, in spite of the large volume of corporate bonds outstanding, 
relatively few issues, such as Bell Canada's, are available in sufficient volume and are well enough known to be very actively traded. The result is a rather "thin market" for all but a few bonds, and any return series based on "market" prices should be interpreted carefully.

\section{EQUITIES}

\section{New Issues of Common and Preferred Shares}

Table 2-5 illustrates that new issues of common and preferred shares are an important source of financing for Canadian business. The dollar volume of these issues depends on the overall need of corporations for funds, as well as their retained profits and target debt-to-equity ratios. Preferred stock issues peaked in 1978 with a heavy volume of sales of term preferred shares. As discussed with income bonds earlier, this high level of activity was stimulated by the knowledge that the favorable tax treatment of the instruments would be curtailed in the November 1978 budget. In the years following 1978, preferred share sales continued to be strong. The shares commonly had some form of option (convertible, retractable) attached.

Sales of new common shares grew over the 1978-82 period as a result of a general growth in companies' funding needs. Corporate short-term borrowing was growing even more rapidly, however, leading to excessive leverage on the part of many corporations. Beginning in 1983, the volume of new equity issues grew even more rapidly, partly as a result of corporations attempting to strengthen their balance sheets, and partly because of a very buoyant stock market.

\section{Stock Exchanges}

There are five stock exchanges in Canada: the Toronto Stock Exchange (TSE), the Vancouver Stock Exchange 
(VSE), the Montreal Exchange (ME), the Alberta Stock Exchange, and the Winnipeg Stock Exchange. The TSE dominates all others in terms of dollar volume of trading (about three-fourths) and dollar value of shares listed. The $\mathrm{ME}$ and VSE are also significant players, and in recent years they have alternated as the second and third largest exchanges behind the TSE. Of these two exchanges, the VSE has pushed hardest to include the more speculative natural resource and venture capital firms, whereas the ME has retained its traditional emphasis on more established firms. All three of these exchanges have aggressively introduced the trading of such new financial instruments as options and futures. The Alberta Stock Exchange has grown modestly in recent years, in step with the Alberta economy, but it represents a minor level of trading activity, largely confined to regional firms and energy stocks. The Winnipeg Stock Exchange is virtually inactive. Table 2-6 compares the level of activity in Canada's three major exchanges over the 1979-87 period.

\section{Trading Arrangements}

The stock trading system in Canada is changing rapidly. As a result, trading in 1987 involved a blend of traditional methods and more recently implemented computerassisted trading.

Under the traditional system, orders to purchase or sell shares are placed with brokers across Canada and abroad. The brokers transmit their orders to traders located on the floor, of the exchange who act as agents for the broker's clients. Traders who are interested in buying or selling a particular stock gather at a designated area of the floor and proceed by public outcry to bid for or offer the shares. When a transaction between two traders occurs, it is 


\section{TABLE 2-6 \\ NUMBER OF SHARES AND DOLLAR VOLUME OF TRADING ON THE TORONTO, MONTREAL, AND VANCOUVER STOCK EXCHANGES 1979 to 1987}

\begin{tabular}{|c|c|c|c|}
\hline \multicolumn{4}{|c|}{ (volume in 000,000 's of shares) } \\
\hline & $\begin{array}{c}\text { Toronto } \\
\text { Stock } \\
\text { Exchange }\end{array}$ & $\begin{array}{l}\text { Montreal } \\
\text { Exchange }\end{array}$ & $\begin{array}{c}\text { Vancouver } \\
\text { Stock } \\
\text { Exchange }\end{array}$ \\
\hline 1979 & 1,390 & 177 & 912 \\
\hline 1980 & 2,009 & 299 & 1,718 \\
\hline 1981 & 1,150 & 204 & 1,574 \\
\hline 1982 & 1,576 & 208 & 1,445 \\
\hline 1983 & 2,440 & 316 & 3,116 \\
\hline 1984 & 2,124 & 401 & 2,260 \\
\hline 1985 & 3,298 & 643 & 2,753 \\
\hline 1986 & 4,907 & 1,096 & 3,493 \\
\hline 1987 & 7,394 & 2,022 & 4,795 \\
\hline \multicolumn{4}{|c|}{ (value in $\$ 000,000$ 's) } \\
\hline & $\begin{array}{c}\text { Toronto } \\
\text { Stock } \\
\text { Exchange } \\
\end{array}$ & $\begin{array}{l}\text { Montreal } \\
\text { Exchange }\end{array}$ & $\begin{array}{c}\text { Vancouver } \\
\text { Stock } \\
\text { Exchange }\end{array}$ \\
\hline 1979 & 18,726 & 2,675 & 1,467 \\
\hline 1980 & 29,514 & 3,856 & 4,419 \\
\hline 1981 & 25,094 & 3,328 & 3,859 \\
\hline 1982 & 17,670 & 2,773 & 1,559 \\
\hline 1983 & 30,193 & 5,088 & 3,962 \\
\hline 1984 & 26,682 & 7,014 & 2,232 \\
\hline 1985 & 44,197 & 10,553 & 2,719 \\
\hline 1986 & 63,684 & 15,983 & 4,485 \\
\hline 1987 & 100,224 & 21,876 & 6,650 \\
\hline
\end{tabular}

Source: Toronto Stock Exchange Official Trading Statistics. 
recorded and all other market participants are informed through electronic means (the "ticker tape").

The Toronto Stock Exchange permits special floor traders (called marketmakers or registered traders) to trade on behalf of their own firms. Out of approximately 500 floor traders at the TSE, approximately 160 are registered traders. In return for the privilege of trading for the firm's own account, each registered trader is assigned responsibilities for certain shares. Nearly all stocks listed on the TSE have been assigned in this way to some registered trader. The trader is expected to engage in stabilizing transactions, which are purchases at prices below, or sales at prices above, the last preceding different-price trade. In addition, the registered trader must be prepared to fill orders for odd lots of shares of the designated stocks.

This system of registered traders differs from the system commonly used in the United States, in which there are the equivalent of traders for the public, traders for firm accounts, and a third group called specialists. The specialist remains at a specific post on the floor of the exchange and deals exclusively in certain stock issues. He carries an inventory of the stock and stands ready to trade with others out of his own account. Floor traders always have the option of dealing with each other or with the specialist. The primary role of the specialist is to maintain and stabilize the market for a stock. It is often asserted that the existence of a specialist makes it possible for the public to make a trade easily and quickly at a price which is not far from the previous price. On the New York Stock Exchange, about one-fourth of the members are specialists. The ME introduced specialists in 1983, and by early 1987 there were 58 equity specialists. The TSE has considered similar action from time to time, but currently retains the registered trader 
system for its equities. Both exchanges employ specialists for options trading.

According to a study by Tinic and West [31], the existence of specialists in the U.S. market causes it, all other things being equal, to have lower bid-ask spreads and lower share-price variability than would be found on the TSE. They assert that the return on Canadian securities, given this higher variability, is higher than on securities traded on the U.S. exchanges even after adjusting for the inherent differences in risk of stocks in the two markets. We return to this notion in Chapter 5 , in which the variability of equity returns in the two markets is compared.

Traditional methods of trading securities are quickly giving way to automated trading. The TSE has three different mechanisms to facilitate trading; these are known as MOST, LOTS, and CATS.

The Market Order System of Trading (MOST) is an efficient method of handling small market orders. The MOST system automatically fills orders for up to 599 shares for all listed stocks and up to 1,099 shares for other interlisted issues. The orders are filled by the registered traders of the respective stocks at the bid or offer prices in effect. The orders are then reallocated to floor traders to allow them to participate in the market. The MOST system is accessed through terminals on the floor of the exchange or located in member dealer offices. The Montreal Exchange uses a similar system called the Montreal Exchange Registered Representative Order Routing and Execution System (MORRE), which automatically allows orders of less than 1,000 shares to be filled at the best market price. The specialist on the trading floor is responsible for taking a position on the transaction.

The Limit Order Trading System (LOTS) is similar to MOST in that it automatically records orders received 
electronically, but the orders may be outside the current market. Unlike MOST, there is no restriction on either the size or the limit price. All orders are filled chronologically as the limit price is reached. All odd-lot limit orders are filled by the registered traders, and other orders are filled by floor traders from offsetting client orders.

The Computer Assisted Trading System (CATS) has been in place since 1978. Subscribers use CATS terminals located in their offices and on the floor of the exchange to enter orders, monitor the status of the market, and receive confirmation of trades. Orders are executed automatically according to a strict priority. This system handles over 800 TSE-listed stocks and represents approximately 20 percent of TSE trading volume.

\section{Size of Listed Companies}

Although it is difficult to prove from available data, it appears reasonable to suppose that the average firm listed on the NYSE is larger than the average firm listed on the TSE. Some support is provided for this proposition when one notes that the minimum listing requirements on the NYSE are larger in terms of assets ( $\$ 16$ million versus $\$ 1$ million) and market value of listed shares ( $\$ 8$ million versus $\$ 350,000)$. Because the TSE/Western equity data base is heavily oriented toward TSE equities and the U.S. data bases used in this study are oriented toward the NYSE, any return comparison between the two markets may reflect different firm sizes in the two markets.

\section{Thin Trading}

Thin trading of a stock is said to occur when the stock is not continuously traded. This means that for extended periods of time (days, weeks, or even months), no trade is recorded on the stock exchange. Such thin trading is 
usually viewed as an indication of a general lack of liquidity for a stock and of an inability to purchase or sell the stock in meaningful quantities without a major price change. Stock exchanges supply the most recent price for each stock listed on the exchange, but in the case of thinly-traded stocks, the price may be for a trade that was consummated some time in the past. For example, the month-end closing stock price for a monthly return-series may be a price from a trade three weeks or more old. As a result of this phenomenon, rate of return calculations for individual stocks may not be representative of the true rate of return available to the investor, and comparison between the rates of return of various stocks may not be valid. In addition, data derived from thinly-traded stocks may cause difficulties for researchers testing stock-pricing models.

Much of the research on thin trading in Canada has been done by Fowler, Rorke, and Jog [7]. These authors analyzed the trading history for all securities listed on the Toronto Stock Exchange at any time during the period January 1, 1970 to December 31, 1979. A number of indicators of thin-trading were devised, but one measure suffices to indicate the severity of the thin trading problem on the TSE. Of 1,800 stocks continuously listed for at least 12 months, 1,043 , or 58 percent, were not traded for one or more months.

\section{Over-The-Counter Market}

An over-the-counter (OTC) market is used for those securities which exist outside of a formal securities exchange. It is sometimes called an unlisted market. Trades are generally conducted over the telephone between securities dealers who may or may not be members of an exchange. The Canadian bond market is a good example of an OTC market. 
The OTC market for common shares comprises three different groups of stocks. In the first group are the shares of large, relatively successful firms which have chosen not to list their shares on an exchange because of the small float or because of a desire to avoid the disclosure requirements. It also includes the shares of firms which have recently gone public and which intend to become listed on one of the stock exchanges in the near future. A second group of stocks are those issued by firms that are reasonably well known, but whose prospects are speculative and which cannot meet the cost or other disclosure requirements of being listed on the exchange. The third group of stocks are speculative issues distributed by broker-dealers on behalf of companies. In these cases, the dealer often has a significant ownership of the shares and the market is very thin.

Historical data on the size of the OTC market is very difficult to obtain. Beginning in 1969, the Quebec Securities Commission began collecting data on OTC trades in Quebec, and in 1970 the Investment Dealers Association of Canada and the Ontario Securities Commission began collecting data on selected unlisted stocks traded in Ontario. By 1984, this list had grown to over 1,500 securities. Of these, only about 100 to 200 traded on a given day.

In April 1986, the Ontario Securities Commission officially introduced a 24-hour computerized information system to assist dealers in trading OTC stocks. The Canadian Over the Counter Automated Trading System (COATS) does not allow subscribers to trade automatically. Instead, it provides information such as bid and ask prices, the last sale price, and the volume of the previous day's trading. Those who wish to trade with each other must still make contact directly. All trades in Ontario through a registered dealer must be reported on COATS. Shares listed on a Canadian exchange are not eligible for COATS, 
but any other shares traded in Canada are eligible, provided the firm whose stock is traded has issued shares to the public and regularly files financial information with the Ontario Securities Commission.

It is apparent that the OTC market in Canada is neither as well-organized nor proportionately as large as the OTC market in the United States. Canada has no equivalent to the National Association of Securities Dealers Automated Quotations (NASDAQ) system which provides a computerized link to OTC traders, complete with current bid-and-ask quotations for a variety of stocks. The lack of such a system in Canada means that many stocks likely are listed in Canada which would be traded over the counter in the United States.

\section{Individual and Institutional Trading}

The trend toward institutional, as opposed to individual, share trading observed in the United States has also occurred in Canada. For example, in 1965 individuals transacted 55 percent of all share trades conducted on the TSE; the proportion had fallen to just over 40 percent by 1986. In spite of accounting for a lower proportion of trades, the proportion of Canadians owning shares in a publicly-traded company or stock mutual fund grew dramatically from 13 percent of the adult population in 1983 to 18 percent of the adult population in 1986. [4]

\section{IMPLICATIONS FOR RATE OF RETURN STUDIES}

The preceding discussion of the evolution of the Canadian capital market suggests that a number of identifiable factors were at work; this may explain the observed returns outlined in Chapter 5. Some of these factors are: 
(1) Active trading of Treasury bills did not begin until at least 1950 and perhaps as late as 1956. Data for the preceding period must be interpreted with caution.

(2) Short-term interest rates tend to move together; consequently, one series adequately captures the behavior of short-term returns. Government of Canada Treasury bill yields are heavily influenced by chartered bank reserve requirements and direct intervention by the Bank of Canada. Their marketability and long history of trading, however, makes them the best choice as a representative short-term return series.

(3) Long-term interest rates also tend to move together; however, they frequently behave differently from short-term rates. For example, short-term rates tend to be more volatile. This suggests that long-term returns may be captured adequately by a single series. Once again Government of Canada long-term bonds are the most desirable choice because of the volume outstanding, ready marketability, and simplicity of the instrument. Because the market is likely to demand a risk premium for them, one would expect other long-term bond return series such as provincial, municipal, and corporate bonds to have a modestly different return.

(4) In contrast with money market securities, a variety of classes of long-term bonds have been traded for an extended period of time. Consequently, it is both desirable and possible to generate return series for municipal, provincial, and industrial 
bonds in addition to the Government of Canada long-term bond return series.

(5) Because a variety of features, such as default risk, callability, extendibility, and pledged collateral, affect bond yields, any bond return index must be designed carefully to identify and allow for changes in these features over time. The number and complexity of these features seems particularly pronounced in recent years.

(6) The marketability of Canadian securities appears to have increased substantially over the past 30 years because of a series of Bank of Canada activities, a greater number of market participants, and a larger volume of outstanding securities. All other things being equal, this marketability may lower returns accepted by investors.

(7) A variety of specific events have affected the supply, demand, and price of Canadian securities. Some of these events include:

- the removal of the 6 percent ceiling on bank loans;

- the Winnipeg Agreement;

- moral suasion or specified interest-rate policies by the Bank of Canada to reduce or encourage domestic borrowing;

- the entry of a greater number of foreign banks into Canada;

- the introduction of major suppliers of capital such as heritage funds and the Canada Pension Plan; and

- the massive refunding of Canada's wartime debt. 
(8) The Canadian equity market appears to be somewhat different from its American counterpart. Some of the differences include:

- smaller firms listed on the major exchange;

- a relatively small over-the-counter market;

- lack of specialists until very recently; and

- thin trading of a large number of stocks.

The impact of these factors could mean higher average stock returns and higher variability of such returns in Canada. 


\section{Taxation of Investment Income}

The rates of return reported in this study were calculated on a before-tax basis. Investors are primarily concerned, however, with after-tax returns. If the tax system changes, the before-tax return required by investors is likely to change as well. Thus, any analysis of observed returns over an extended time period should properly take into account changing tax environments. This chapter focuses on the major tax changes affecting investments in Treasury bills, bonds, and common shares over the period covered by the return data, 1950-86. Where appropriate, we also point out the proposed changes in the tax system as a result of the June 1987 White Paper on Tax Reform [33] and the Notice of Ways and Means Motion to amend the Income Tax Act tabled in Parliament on December 16, 1987.

\section{TAX LEGISLATION}

In Canada, investment income is determined in accordance with rules set by the federal authorities. The Department of Finance initiates the government's tax policy, and the Minister of Finance introduces tax legislation into Parliament, usually as part of an overall budget. Following debate in Parliament, which often results in amendments, the proposed legislation is passed into law. 
The law is administered by the Department of National Revenue Taxation. Once taxable income has been determined, the federal government applies a tax rate which is uniform across the country. Then each province imposes an additional tax on the taxable income. Provincial tax rates vary, but the computation of taxable income is reasonably consistent throughout the country.

The Income Tax Act, a federal statute passed in January 1949, was the major legislation affecting the taxation of investment income until the end of 1971. Effective January 1,1972 , the Income Tax Act was extensively revised and this legislation, with modifications, has remained in place until the present time. This major revision in 1972 has come to be known as Tax Reform. A series of amendments to the Act, as well as changes in regulations which have affected the taxation of investment income, have been added since 1972. On June 18, 1987, the Government of Canada put forth a White Paper on Tax Reform. This paper proposed a number of changes in the system of taxation, some of which were immediate and others of which were to be implemented over a period of one or more years.

The following discussion involves the taxation of earnings obtained from trading the securities of concern to this study. These earnings include capital gains, dividends, and interest income.

\section{TAXABLE INVESTMENT INCOME}

\section{Calculation of Taxable Income}

Under the Canadian tax system, the calculation of individual tax begins with the identification of income from sources such as employment, pensions, and investments. The individual is then permitted to make deductions for a variety of items, such as dependents and charitable 
donations, to derive taxable income. A preliminary calculation of tax is made on this income using a progressive tax system. The individual is then permitted to deduct a number of tax credits which lower the tax payable. Over time, various governments have modified the set of income which is taxable, the size and availability of exemptions, the tax rates and categories of income to which they applied, and the availability of tax credits. A key feature of the 1987 White Paper was that the Government of Canada proposed to convert many of the existing exemptions into tax credits, thereby ensuring that the tax benefits would fall equally on persons in all tax brackets. Another significant proposal was to decrease the number of tax brackets from 10 to 3 effective January 1, 1988.

\section{Capital Gains}

One of the most significant results of Tax Reform was the introduction of a tax on capital gains beginning in January 1972. A capital gain occurs at the disposition of an asset. The amount of the capital gain is the difference between the selling price and the "adjusted cost base" of the asset. The adjusted cost base is the purchase price of the asset adjusted for such items as brokerage charges, which are presumed to have added to, or lessened, the cost of the asset.

In Canada, capital gains are not taxed at a special rate. Instead, the taxpayer simply adds one-half of the capital gain (usually called the taxable capital gain) to taxable income. The tax payable is then computed on all taxable income at the taxpayer's regular income tax rate.

In general, one-half of the capital losses (usually called allowable capital losses) must be deducted from capital gains before computing taxable capital gains. If allowable capital losses exceed taxable capital gains, and if the taxpayer is a corporation, the net allowable capital loss is not 
deductible from other taxable income. Instead, the net allowable capital loss may be carried back one year and carried forward an unlimited number of years for purposes of offsetting taxable capital gains. For individuals (as opposed to corporations) the capital gains tax rules changed in 1985. From 1972 to 1981, a net allowable capital loss could be deducted from other taxable income up to $\$ 1,000$ in any one year. Any net allowable capital losses above this $\$ 1,000$ yearly limit could be offset against the past year's taxable income or could be carried forward indefinitely. From 1982 to 1985, the same rules were in place but the net allowable capital loss was raised to $\$ 2,000$. The new rules applying to the period since 1985 are discussed below.

To accommodate the transition from nontaxable to taxable capital gains, it was necessary for investors to place a value on all capital assets, applicable to the beginning of 1972. For this purpose, December 22, 1971, was declared "valuation day" for all publicly-traded securities. Subject to certain transitional rules, the value of securities as of that day became the deemed cost of these securities for purposes of subsequent capital gains calculations.

As a general rule, individuals and corporations are subject to capital gains taxes if their income is taxable at all. A significant exception to the rule applies to individuals or businesses considered to be actively carrying out the business of security trading. In such cases, all capital gains or losses are deemed to be business gains or losses, and are subject to normal income tax rules.

The introduction of the capital gains tax in Canada in 1972 led to the phenomenon of tax-loss selling, which was already popular in the United States. Tax-loss selling takes place if an investor holds a security which has fallen in price, the sale of which will lead to a capital loss. Tax-loss selling may occur near the end of the calendar year so that the tax 
benefit is immediate rather than deferred several months. In Canada, a sale is only deemed to have taken place on the settlement date of the transaction, which usually occurs five business days after the actual transaction. Consequently, there is likely to be tax-loss selling pressure during the first three weeks of December, but none during the final week. Frequently, investors repurchase the same stock at a later date because they believe the stock is a good investment. If this repurchase occurs within thirty days after the sale date, the Income Tax Act deems the capital loss to have been superficial and not allowable for tax purposes. Consequently, investors typically are advised to delay repurchase for thirty days, or switch to equivalent securities or to options of the sold security.

In May 1985, the federal government introduced a lifetime capital gains exemption of $\$ 500,000$ ( $\$ 250,000$ of taxable income) for gains realized at any time after 1984 . This exemption was to be phased in over six years as follows:

$\begin{array}{lc}\text { End of } & \text { Cumulative Limit } \\ 1985 & \$ 20,000 \\ 1986 & 50,000 \\ 1987 & 100,000 \\ 1988 & 200,000 \\ 1989 & 300,000 \\ 1990 & 500,000\end{array}$

The investor had the option of using or not using part of the cumulative limit for any given capital gain or loss. During the phase-in period, capital gains realized in a given year exceeding the cumulative limit could not be deferred to future years. 
Example. Suppose that 10,000 shares were purchased for $\$ 50,000$ including transaction costs and were sold in 1985 for $\$ 80,000$. The taxable capital gain calculation follows. (Assume that the investor has not claimed any previous capital gains, and wishes to apply the appropriate exemption.)

$\begin{array}{ll}\text { Proceeds } & \$ 80,000 \\ \text { Cost } & \$ 50,000 \\ \text { Capital Gain } & \$ 30,000 \\ \text { Exemption } & \$ 20,000 \\ \text { Remainder } & \$ 10,000\end{array}$

Taxable Capital Gain $\$ 10,000$ x $0.5=\$ 5,000$.

Beginning in 1985, net capital losses could not be deducted from other income. Instead, the investor could elect to increase his lifetime capital gains exemption by the amount of the net capital loss.

When a number of equivalent securities are purchased at various prices the adjusted cost base is the average cost of all securities purchased.

Example. Suppose 1,000 shares of a company are purchased for $\$ 5$ each. One month later, another 2,000 shares are purchased for $\$ 6.50$ each. Two months later 500 of the shares are sold for $\$ 7$ each. The capital gain on the sale, assuming the investor has exceeded the capital gains exemption limit, is as follows. 
Value of first purchase $(1,000 \times \$ 5)=\quad \$ 5,000$

Value of second purchase $(2,000 \times \$ 6.50)=\$ 3,000$

Total Value of shares $=$

$\$ 18,000$

Cost per share $(\$ 18,000 / 3,000=\$ 6.00)$

Proceeds of Sale $(500 \times \$ 7.00)=$

$\$ 3,500$

Adjusted Cost Base of shares sold
$(500 \times \$ 6.00)=$
$\underline{\$ 3,000}$
Capital Gain
$\$ 500$

The 1987 White Paper introduced a number of changes in the taxation of capital gains. The lifetime capital gains exemption for individual investors was decreased to $\$ 100,000$, except when the gain was the result of the sale of qualified farm property or the shares of small business corporations, both of which continue to qualify for the $\$ 500,000$ limit. Because the original $\$ 500,000$ limit was being phased in, and the 1987 limit was $\$ 100,000$, no special adjustments are required. The proportion of capital gains to be included in a taxpayer's income was increased from 50 percent in 1987 to 66.67 percent in 1988 and 1989, and to 75 percent in 1990 and beyond. The amount of capital gains eligible for the capital gains exemption was to be reduced by cumulative investment losses including interest expense claimed after 1987.

\section{Cash Dividends}

In general, dividends received from public corporations must be included in taxable income. Tax authorities have long recognized that this could lead to double taxation, however, as profits are taxed in the hands of the corporation and again in the hands of the shareholder when dividends 
are received. It could even lead to triple taxation if dividends paid between corporations were subject to tax. To eliminate or at least ameliorate this problem, the government has, over the years, devised a number of expense deduction and tax credit mechanisms.

Over the entire 1949-86 period, dividends received by Canadian corporations from another taxable Canadian corporation were to be included in taxable income. An expense deduction was allowed equal to the dividend received, however. The net impact of this rule was to make such dividends nontaxable in the hands of the recipient corporation.

From 1949 to 1972, an individual taxpayer was required to include dividends in taxable income but was permitted to deduct 20 percent of such dividends from tax payable as a tax credit. This had the effect of making dividends tax-free to individuals in the 20 percent tax bracket or below, and lowered the effective tax rate on dividends received by those in higher tax brackets. Beginning in January 1973, this procedure was replaced by a "gross up" and tax credit system. Under the new system the shareholder was required to increase dividends by one-third, and this grossed-up amount was added to taxable income. Then the shareholder was permitted to deduct 20 percent of this grossed-up amount directly from tax payable. This introduction of the gross up system resulted in a lower effective tax rate for those in lower tax brackets. Since that time, the amount of the gross-up and tax credit have been changed a number of times. These changes are summarized in Table 3-1. As of the end of 1986, the gross up was 33.33 percent and the tax credit was 16.67 percent. ${ }^{1}$

${ }^{1}$ There is sometimes confusion surrounding the tax credit because it can be expressed as 16.67 percent of the grossed-up dividend or 22.22 percent of the actual dividend received. 


\section{Table 3-1 \\ Dividend Gross Up and Tax Credit System \\ in Force \\ 1949 to 1986}

Calendar Years

1949-72

1973-78

$1979-81$

1982-85

1986

\section{Gross Up (\%) Tax Credit (\%)}

An example of the current computation follows.

Cash dividend received

Gross up (33 1/3\%)

Taxable income

Assumed marginal federal tax rate ${ }^{a}$

Federal tax payable $(0.34)(\$ 1,333)$

Tax credit (16 2/3\% of $\$ 1,333$ )

Net federal tax payable

Assumed provincial tax rate ${ }^{\mathrm{b}}$

Provincial tax payable (0.50)(\$231)

Total tax payable on dividend $(\$ 231.00+\$ 115.50)$

Effective federal tax rate

Effective federal and provincial tax
$\$ 1,000$

333

$\$ 1,333$

$34 \%$

453

222

$\$ 231$

$50 \%$

$\$ 115.50$

$\$ 346.50$

$23.1 \%$

$34.6 \%$

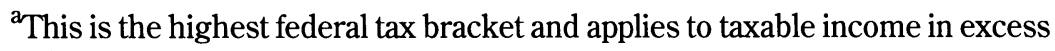
of $\$ 62,657$.

${ }^{\mathrm{b}}$ This is the rate in Ontario. Other provinces have rates ranging from 43 to 60 percent.

The 1987 White Paper proposed the reduction of the dividend gross up from 33.33 percent in 1987 to 25 percent in 1988 , and a reduction of the tax credit from 16.67 percent 
of the grossed-up amount to 13.33 percent of the grossed-up amount.

\section{Comparisons of Capital Gains and Dividend Tax}

During the 1949-72 period, the absence of a tax on capital gains meant that dividends, in spite of the special tax credit, were taxed at a higher marginal rate than capital gains for all taxpayers above the 20 percent tax bracket. With the introduction of the capital gains tax in 1972, dividend income had a lower effective tax than capital gains for taxpayers in the 32 percent or lower marginal federal tax bracket. Above this level, capital gains had a lower effective tax rate. Several authors [1,16] have noted that these tax changes created a greater overall investor preference for dividends. The relative prices of high dividend-paying stocks rose after the tax change.

The more generous gross-up and tax credit introduced in 1979 raised the break-even marginal tax rate to 37.5 percent. In that year the maximum federal rate was 43 percent and began at taxable income of $\$ 60,000$. Consequently, a reasonably substantial group of taxpayers still favored capital gains over dividends. The 1982 gross-up change lowered the break-even marginal tax rate to 34 percent but at the same time the highest marginal federal tax bracket was lowered to 34 percent at a taxable income of $\$ 56,578$. As a result, from 1982 to 1984 dividend income for all investors was taxed at a rate less than or equal to capital gains. This situation changed abruptly in 1985 , with the introduction of the lifetime capital gains exemption and changes which made the dividend tax credit less attractive. After 1985, all investors who had not used up their exemption would either clearly favor capital gains, or be indifferent between capital gains and dividends. Those investors who had used up their capital gains exemption 
would either favor dividend income or capital gains, depending on their tax brackets.

As a result of the decreased rate of tax on dividends and the increased rate of tax on capital gains proposed in the June 1987 White Paper, the existing preference for capital gains was removed.

In summary, the preceding discussion points out that the federal government has pursued a very ambiguous strategy regarding the relative desirability of dividends and capital gains over the years. At some times, capital gains have been favored over dividends; during other periods the reverse has been true. For much of the period discussed, lower-income taxpayers have preferred one type of income, and higher-income taxpayers have preferred a different form of income, but the tax bracket dividing these two groups has changed over time.

\section{Pre-1972 Surplus}

With the introduction of Tax Reform in 1972, corporations were permitted to distribute surplus already on hand at somewhat reduced tax rates. Surplus that could have been distributed without tax prior to 1972 was called "capital surplus on hand," and surplus that could only have been distributed as a taxable dividend was called "1971 undistributed income on hand." Under the revised Act, corporations were allowed to pay a 15 percent tax on 1971 undistributed income on hand, and pay the remainder to shareholders in the form of a nontaxable dividend. Furthermore, all capital surplus on hand could be paid to shareholders as a non-taxable dividend. Although these two types of dividends were not taxed as dividends in the hands of the recipients, they did decrease the adjusted cost base by the amount of the dividend, thereby creating a potential for a capital gains tax. Effective January 1, 1979, the right of 
corporations to distribute these special surpluses was discontinued. This action meant that during 1977 and 1978, there was some stimulus for the corporations to distribute large amounts of tax-paid dividends before the right to do so expired.

As a result of this special tax treatment of certain dividends, many corporations created two classes of shares-one which paid out taxable dividends, and another which paid out tax-paid dividends. These latter tax-paid dividends were to be paid out as long as the tax-paid undistributed surplus lasted. The shares were typically interconvertible at the option of the shareholder. With the introduction of the two classes of shares (usually labeled class A and class B), shareholders were faced with deciding which shares to hold in their portfolios. Although this choice was quite complex, it essentially hinged on the marginal tax bracket of the investor and how long he intended to hold the shares. In general, investors with low combined federal and provincial marginal tax rates (less than 40 percent) preferred regular dividends, whereas those in high tax brackets (greater than 56 percent) preferred tax-paid dividends. Those who had a marginal tax rate of 40 to 56 percent would tend to prefer regular dividends if they expected to retain their investment a relatively short time, and tax-deferred dividends if they intended to hold the shares a relatively long time. Tax-exempt organizations such as charities and pension funds preferred regular dividends, as these were larger on an after-tax basis.

\section{Stock Dividends}

A stock dividend occurs when some dollar amount is transferred from the earned surplus (retained earnings) account of a corporation into the share capital account. New 
shares (the stock dividend) are normally created and distributed to existing shareholders to reflect this transfer.

The Income War Tax Act provided that such stock dividends were taxable in the same fashion as regular cash dividends, with the deemed dollar value of the dividend received equal to the dollar value transferred into capital stock, divided by the number of new shares issued. This remained in effect until March 1977, after which time any stock dividends received were no longer taxable. Currently, however, stock dividends are assigned a deemed value of zero, and are included in the adjusted cost base of shares owned. As a result, when the shares are ultimately sold they may result in a capital gain.

\section{Interest Income}

Interest income is generally taxable in the same way as other income.

\section{OTHER TAX CONSIDERATIONS}

A number of bodies are exempt from income tax. The most important are governments, certain governmentowned corporations, and pension funds. Other entities, such as mortgage investment companies and mutual fund trusts, act as conduits allowing capital gains, interest, and dividends to flow through the entity free of tax, as if the securities were owned directly by the investor. The taxation of insurance companies is much more complex and has been subject to much change since Tax Reform.

At a personal level, the first $\$ 1,000$ of interest income or grossed-up dividends is tax-free in any given year. This investment income deduction was initiated in 1975. Until the introduction of the lifetime capital gains exemption in 1985 , taxable capital gains also qualified for the $\$ 1,000$ 
investment income deduction. Individuals may set aside certain amounts each year in Registered Retirement Savings Plans (RRSPs). The amounts set aside may be deducted from taxable income. The maximum allowable amount increases each year beginning in 1989. The effect of the White Paper in June 1987 was to slow down the rate at which these annual increases would occur. The plan's income is not taxed as earned, and, consequently, no distinction is made between capital gains, interest, and dividends. When the RRSP is deregistered, any lump sum or periodic amounts received by the investor are taxed as regular income. This means that for purposes of such funds, all forms of income are taxed equally. To the extent that the current tax structure favors dividends and capital gains, the taxable investor may begin to see fixed-income interest-earning securities in a more favorable light. Because these pools of funds are growing, they may be expected to have an increasing impact on the prices of securities.

The 1987 White Paper eliminated the $\$ 1,000$ investment income deduction for interest and grossed-up dividends as of 1988.

\section{Indexed Security Investment Plans}

With the rapid acceleration of the inflation rate in the 1970 s, it became increasingly apparent that taxation of nominal returns left investors with a declining after-tax real return. In an effort to preserve the real purchasing power of investors, the federal government introduced an Indexed Security Investment Plan (ISIP), effective October 1, 1983. Under this plan, investors who set their funds aside in a registered ISIP would pay tax only on the real returns experienced after adjusting for inflation. The ISIPs could be sold by a wide variety of financial institutions to Canadian 
investors. An ISIP had to contain qualified securities which generally included most listed common shares of Canadian corporations. With the introduction of the lifetime capital gains exemption in 1985, these plans were repealed.

\section{Implications for Rate of Return Studies}

The preceding discussion clearly points out that the rules for taxation of Canadian investment income are both complex and constantly changing. It is useful to highlight how these changing rules may affect observed capital market returns.

(1) The inflation rate increased steadily over the 1950-83 period. Given that investors seek to earn a real return, nominal returns should have increased over this period as well. Moreover, because taxes are levied on nominal returns, one would expect these returns to rise over time to accommodate increasing taxes. This impact could be somewhat offset by changing tax rates on investment income.

(2) The capital gains tax imposed for the first time in 1972 should have caused investors in some tax brackets to shift their preference away from capital gains and toward other types of returns. As a result, the before-tax return demanded from securities promising a capital gain should have increased. ${ }^{2}$

(3) Because of their favorable tax treatment, both dividends and capital gains should be preferred over interest income by tax-paying investors.

${ }^{2}$ For studies that partially address this issue see Morgan [20], Booth and Johnston [3], and Lakonishok and Vermaelen [16]. 
(4) For many years the substantial dividend tax credit favored dividend-paying stocks over nondividendpaying stocks for a large part of the investor population. Because of changing regulations, this favoritism was extended over time to a growing group of potential investors. With the introduction of the lifetime capital gains exemption, this situation has been reversed for a substantial number of investors, particularly those with modest amounts of wealth.

(5) The preference for dividends over capital gains in Canada (for those who have used up their lifetime capital gains exemption) is opposite to the situation in the United States, where capital gains are favored. (In the United States, long-term capital gains and dividends are currently taxed as ordinary income.)

(6) The lack of taxation of certain financial institutions (e.g., pension funds) and of certain individual accounts (RRSPs) means that for tax reasons, the market is made up of those who tend to prefer interest income and those who do not.

(7) The designation of pre-1972 surplus led to the creation of new types of shares with tax-paid dividends and another without tax-paid dividends. These shares appealed to investors in differing tax brackets. Multiple classes of shares have been created for a variety of other reasons as well, such as the preservation of control and the facilitation of dividend reinvestment plans.

(8) The system of capital gains taxes introduced in Canada in 1972 may have led to the same December tax-loss selling activity reputed to occur in the 
United States. ${ }^{3}$ The lifetime capital gains exemption introduced in 1985 , however, may have decreased the frequency of tax-loss selling. 


\section{Data Description and Sources}

This chapter describes each of the major types of data employed in the study. The data include returns on Treasury bills; federal, municipal, provincial, and industrial bonds; and equities. An inflation-rate series is also created. Before we begin, however, a discussion of how and why we resolved some concerns is in order.

One of our first concerns was the availability of the proper data for the proper intervals used in this study. For most types of research work the differencing interval should be as short as possible. Ideally, this means that data on every trade should be utilized. In our case, individual trade data were not available, and although daily stock-price data could have been obtained, it would have been very costly. ${ }^{1}$ Moreover, the shortest differencing interval readily available for all nonequity securities was monthly. Consequently, monthly returns were utilized.

A second concern was the time period over which returns should be measured. Stock-price data were available for some stocks going back to January 1950. Although we could have gone further back in time, costs would have been

\footnotetext{
${ }^{1}$ Daily stock price data are available through the TSE/Western database, but it covers only the period since 1975 and the purpose of this study is to focus on a more extended period.
} 
high, data less readily available, and the benefits of observing the wartime period dubious. Further, as discussed earlier, money market and bond market data before 1950 are somewhat suspect. As a result, December 31, 1949 was taken as the starting point. December 31, 1987, was chosen as the end point to include the October 1987 market crash.

The method employed to determine rates of return was the third concern. Consider a portfolio whose value increases from $\$ 100$ to $\$ 120$ in the first period, then falls to $\$ 96$ in the second period. The rate of return in the first period is 20 percent and in the second period is minus 20 percent for an arithmetic average return of zero. For some purposes, this arithmetic return is appropriate, such as when asking the question, "What is my best guess of next period's expected rate of return?" On the other hand, it is clear that the wealth of the investor has actually fallen over the two periods from $\$ 100$ to $\$ 96$. The geometric return of -2.02 percent per year $\left\{[(1.20)(0.80)]^{1 / 2}-1\right\}$ accurately reflects the change in wealth over time. Recognizing these two different expository objectives, it was decided that many of the results would be reported in the form of both arithmetic and geometric returns.

\section{TREASURY BILLS}

Each week the Government of Canada sells by tender a quantity of 91-day Treasury bills. These non-couponbearing bills are sold at a discount to mature at par. A monthly series of the average yield of these newly-issued Treasury bills was obtained from Statistics Canada (Cansim Number B14007), and formed the base for our subsequent calculations. The particular series chosen was the average yield at tender on the last Wednesday of the month. 
Because the series represented ex ante quoted yields to maturity for 91 days rather than the desired one-month return, it had to be converted. For each month, the ex post return was computed by determining the hypothetical Treasury bill price at the beginning of the month and at the end of the month. The return was then computed as the percentage increase in price during the month in question. The price at the beginning of the month was the price at which a Treasury bill, maturing in 91 days, would have to trade to generate the annual yield to maturity for the month provided by Statistics Canada. The price at the end of the month was the price at which a Treasury bill, maturing in 61 days, would have to trade to generate the same annual yield to maturity as the most recently issued Treasury bills. These calculations are expressed mathematically in Appendix A.

This method of deriving a monthly rate of return makes at least two implicit assumptions which should be noted. First, it assumes that there was a ready market for these bills. In the early years, there is some question whether this was true. Our preceding discussion of the Treasury bill market pointed out that there was little trading before at least 1953 and perhaps as late as 1956. Second, it assumes that the yield curve for all Treasury bills with a maturity of 91 days or less is flat.

Two alternative approaches to generating a monthly return series would have been theoretically more satisfying: namely, to gather monthly Treasury bill price quotes from actual trades, or to obtain a series of 31-day yields from tender sales. Unfortunately, neither type of data was available. 


\section{BONDS}

\section{Bond Returns in General}

Most studies of capital market returns are concerned with the rate of return that is available from bonds in a given risk class. To estimate this rate of return, ex post returns for a sample of bonds are measured over successive time periods, usually assuming that these observations are periodic drawings from some underlying stable distribution of returns. To make these successive observed returns comparable, the characteristics of the bonds whose returns are being measured must be as identical as possible from one period to the next.

One of the major factors known to affect bond yields is the term to maturity. Because virtually all bonds have a specific expiry date, their term to maturity decreases with the passage of time. Consequently, successive observed returns for a given bond capture not only the return demanded in the market for the level of default risk, but also a changing term structure effect. To adjust for this effect, it is common for researchers to measure the returns for bonds with some initial term to maturity, such as 15 years, and as time passes, to replace these bonds with new bonds whose term to maturity is within the original 15-year target range.

Other factors affect bond yields as well. These include the default risk, collateral security, marketability, coupon, and any options attached to the bond such as convertibility, extendibility, retractability, and callability. As the bonds in a sample are regularly replaced over time, they should be replaced by bonds which are identical along all of these dimensions to accommodate the problem of changing term. In practice, because it is not possible to find perfect substitutes, any bonds chosen are, at best, approximations to the ideal. 
The rate of return for a given period is typically the average return across several securities. This raises another computational issue: namely, how much weight to give each security when computing the average. One alternative is to give equal weight to each bond issue by computing the arithmetic average return over all bonds in each sample period. The disadvantage of this method is that it gives equal weight to securities of small issuers (such as the province of Prince Edward Island) and large issuers (such as the province of Quebec). A preferred solution is to compute a value-weighted return for all bonds in the default risk class. In addition to being representative of available yields, this method of computation reflects the change in wealth available to investors whose funds were tied up in the given class of securities over the period under consideration.

In summary, the most appropriate measure of ex post bond returns is a value-weighted average return derived from a continuously changing sample of bonds which are identical over time in all respects. The following discussion outlines how well these general principles were applied in generating monthly long bond return series.

\section{Government of Canada Bond Returns}

The Bank of Canada has collected monthly bond-yield data for Government of Canada bonds with one to three, three to five, five to ten, and over ten years to maturity. For each series, the monthly yields are the arithmetic average of the yield to maturity of all bonds which in the given month had a maturity date within the specified range. They encompass all marketable bonds including extendibles, but excluding perpetuals and Canada Savings Bonds.

We decided to report rates of return derived from the over 10 years series (Cansim B14013), rather than the shorter 
maturity series for three major reasons: (1) the term structure effect is lowest; (2) the bias caused by the existence of the extendibles is minimal; and (3) the series compares well with other bond series used in this and other studies.

As discussed earlier, the term to maturity has an effect on a bond's yield. For all of the Government of Canada yield series, the average term to maturity is constantly changing because of the passage of time and the issue of new bonds by the federal government. Data on the average term to maturity within each of these series are not readily available. Observation of typical term structure curves suggests, however, that for longer-term bonds the yield curve is quite flat regardless of the steepness of the slope for shorter-term bonds. This suggests that a changing average term to maturity within the class of longer-term bonds would introduce less error into the calculation of returns than a changing average term to maturity for shorter-term bonds.

The inclusion of extendible bonds may cause bonds to be, in a sense, allocated to an incorrect maturity class. This might occur because, although bonds may have an initial maturity of, say, two years, the market could expect to extend the bond, pricing it as if it were a much longer-term bond. The net effect is that some bonds that the market treats as long term are included within the short-term bond category, biasing the observed average yield. Discussions with the Bank of Canada disclosed that for short-term bonds, the exclusion of all extendible bonds changed the average yield of the published series in some months by over 100 basis points. On the other hand, deleting all extendible and retractable bonds from among long-term bond series has virtually no impact on the reported average yield. 
The third, and perhaps most important, reason for concentrating on long-term bonds is to make the results comparable with the available industrial, provincial, and municipal bond series, all of which are long term.

Having decided to use the yield series based on bonds with a term to maturity of over 10 years, the next step was to convert the series into monthly returns. This was accomplished by first assuming that an investor bought a bond at par at the beginning of each month, and sold the same bond one month later at a price determined by end-of-month interest rates. To this capital gain or loss was added one-twelfth of the yield promised at the beginning of the month to account for deemed interest income. To derive a bond price at the end of each month, it was necessary to assume some term to maturity for the bond being sold. Observation of the average maturity structure of long-term Government of Canada bonds over several years suggested that an assumed term of 17 years was reasonable. Subsequent replication of the research with a range of other assumed terms changed the results only a modest amount. The specific calculation methods are outlined in Appendix B.

\section{McLeod, Young, Weir Bond Returns}

The best-known bond index in Canada is the McLeod, Young, Weir (MYW) 40 Bond Index. The 40 Bond Index comprises four different groups of bonds: 10 utilities, 10 municipals, 10 provincials, and 10 industrials. These four yield series, created in December 1947 and updated monthly since then, have provided the basic data for virtually all studies of Canadian bond returns. Because they represent the best available data over the 1950-87 period, we have chosen to use these four series as well. 
The MYW 40 Index has a number of limitations. First, the yield on the index and each subindex is simply the arithmetic average of the yields on the component bonds. A value-weighted index is preferred. Second, the bonds in the 40 Index are not controlled, except ad hoc, for changes in quality over time. Third, periodic thinness of some sectors of the Canadian bond market made it difficult to keep the average term to maturity constant and keep other factors such as coupon, call features, and the like constant. To address these issues more effectively, MYW created a number of new indexes, including the Weighted 50 Long Bond Index (1976), Weighted Mid-Term Bond Index (1979), Weighted Short-Term Bond Index (1986), and all-maturity Universe Bond Index (1986). Although these indexes are superior in some respects to the MYW 40, we decided not to use them because of the short time period covered.

\section{COMMON SHARES}

The common share data employed for this study were derived from a newly-created database called the Toronto Stock Exchange/University of Western Ontario Database. We refer to it as the TSE/Western Database. This equity database contains daily and monthly prices, shares outstanding, split, and dividend data for a sample of Canadian stocks. (The actual number of stocks varies from period to period as listed companies appear and disappear. The maximum number of issues, including warrants, rights, equity, and installment receipts, for any period is 3,685 .) Monthly data are available for the period December 1949-December 1987 inclusive, and daily data 
are available for the period January 1, 1975-December 31,1987 inclusive. $^{2}$

The TSE/Western database began with a block of data provided by Wood Gundy, was expanded substantially by the authors at the School of Business Administration at The University of Western Ontario, and then verified and further expanded through a cooperative arrangement with the Toronto Stock Exchange.

\section{The Wood Gundy Database}

The Wood Gundy stocks were primarily from firms listed on the TSE, but also included stocks listed on the ME and VSE, depending on Wood Gundy's needs. For that reason, the TSE/Western database still contains a few non-TSE listed securities. Although the Wood Gundy data generally pertained to the January 1950-December 1982 period, there were many gaps. For example, prices for shares of Bethlehem Copper were only provided for the December 1963-December 1969 period, necessitating the gathering of data back to 1950 and after 1969 . These gaps were filled, and wherever possible, data on predecessor and successor companies were gathered as well. For example Agnico-Eagle Ltd. was formed in 1972 by the merger of Agnico Mines Ltd. and Eagle Gold Mines Ltd. Data on these two pre-merger companies were gathered as far back as possible. Information on these and other predecessor firms was located through the Financial Post Corporation Service cards, and the price and other data were gathered from back issues of the TSE Review. Only those predecessors listed on the TSE were included. Furthermore, predecessor companies were included if the successor was formed by

\footnotetext{
${ }^{2}$ For additional information on the availability of this database contact the Economics Department of the Toronto Stock Exchange.
} 
merger, but not if the company was acquired through a cash purchase.

Missing data on shares outstanding at the end of each month were derived from the stock exchange monthly reviews, and verified using Financial Post cards. Discrepancies between the two sources were identified and corrections made. Stock-split data were obtained largely from Financial Post Corporation Cards, and dividend data were obtained from the Financial Post Corporation Dividend Record.

The Wood Gundy database was found to contain modest errors, largely related to mistakes in data entry. These, of course, are common to any database and can only be detected and removed through careful cleaning and repeated use.

\section{Addition of TSE Data}

The preceding data formed the basis for our original study, Canadian Stocks, Bonds, Bills, and Inflation: 1950-1983. Following publication of that work, we formed a relation with the Toronto Stock Exchange which enabled us to expand greatly the size of the database. The database now includes all stocks which were in the original database over the 1950-75 period, plus all stocks that were ever listed on the Toronto Stock Exchange over the January 1, 1976-December 31, 1987 period. The cooperation of the TSE not only added to the size of the database, but also permitted us to perform additional checks on the original data provided by Wood Gundy and Western and allowed us to obtain dividend and capital change data directly from the TSE. 


\section{Contents of The 1949-1975 Subsample}

As already indicated, from 1975 to 1987 the database contains all stocks traded on the TSE. Similar data were not readily available for the period preceding 1975 . Therefore, a decision had to be made regarding which stocks to include.

Early in the data-gathering exercise, it was decided that the database should, at a minimum, include all stocks which had ever belonged to the TSE 300 Index. This would permit, in the future, a variety of research projects centering on the representativeness of the index as a measure of Canadian security returns. Wherever possible we also gathered data on all firms which were predecessors to those in the TSE Index. For example, if two firms merged and the surviving firm became part of the index, data were gathered on the two predecessor firms as well.

The TSE Index is quite different from all other North American stock-price indexes. Beginning in 1976, the TSE computed, for each listed stock, the total value of all outstanding shares less the value of shares held as large blocks (prior to 1976 the size of identified blocks was 50 percent or more of outstanding shares, after 1976 the blocks consisted of 20 percent or more of outstanding shares). The stocks were then ranked in accordance with the dollar value of the float outstanding, and the top 300 by value were included in the index. Since that time, mergers, acquisitions, and share-price changes caused some stocks to be added to the top 300 and others deleted. (The number of stock changes varied from a low of 18 in 1982 to a high of 52 in 1981.) As a result, the shares of far more than 300 companies have at one time or another been included in the TSE 300. The price index itself is a value-weighted index based on the value of the float outstanding for each of the top 300 securities. The TSE Index was generated back to 
1956 by observing the returns earned only on the stocks in the original 1976 top 300 for all years back to 1956. Many of these stocks were not listed as far back as 1956. Consequently, for the years preceding 1976, the TSE 300 actually consists of far fewer than 300 stocks.

\section{Classes of Stock}

If there was more than one class of stock in a company, the general rule was to include only the stock with the most junior claim on earnings. Although the TSE/Western database includes data on preferred shares, warrants, rights, and other types of issues, the rate of return calculations in this study include only equities.

As discussed earlier, special tax rules during the 1972-78 period caused the introduction of a large number of class $A$ and class B common shares. Wherever possible, both classes were included in the database because, in a number of circumstances, the shares were interconvertible. The data indicate that when two of these share classes are outstanding, only one class tends to trade actively.

\section{Mergers}

The general convention followed in the case of mergers was to treat the company resulting from the merger as if it were a new company. This means that the data series on the merging companies ends on the date of the merger and a new single series begins.

\section{Stock Splits}

If there were a stock split, a split factor was noted in the file. For example, if the stock split two for one, the split factor was two. The effective date of the split was noted. 


\section{Dividends}

All cash dividends were recorded as of the ex-dividend date. This is in contrast with some databases which have recorded dividends as of the payment date. Stock dividends were treated like stock splits, using a quasi-split factor to reflect the increase in shares outstanding. If a dividend were paid in another class of stock, the cash value of the dividend was estimated and entered as a cash dividend on the ex-dividend date. In some cases, the investor had a choice of a cash dividend or a stock dividend. In these cases, we utilized a cash dividend reflecting the dollar amount of cash paid out, as well as a quasi-split factor to reflect the increase in outstanding shares.

\section{Canadian Currency}

Prices are generally in Canadian dollars. For those firms with dividends quoted in U.S. dollars, an exchange rate was used to convert the data into Canadian dollar equivalents. The exchange-rate series employed was the average of noon spot rates obtained from Statistics Canada (Cansim B3400).

\section{Securities Not Traded}

If a stock was not traded, we did not insert some other value such as the mid-point of the bid-ask quote.

\section{Cleaning the Data}

Data from secondary sources were gathered on code sheets and visually inspected for accuracy and reasonableness. These data were entered twice and the two data sets compared for equivalence. A preliminary check was made of each stock to see if monthly observations were present for the entire 1950-86 period. If there was a gap in the data, our files were checked to see if the cause was a 
bankruptcy, a delisting, a merger, or some other explainable event. If not, further research was conducted to gather the missing data. If no price could be obtained, a missing value was indicated rather than a price constructed through bid-ask data.

Changes in outstanding shares were compared with data on stock splits for consistency in amount and timing. Perhaps the most effective screen was to compute the rate of return for individual securities in two ways: employing the stock-split factors and employing the total shares outstanding, and then comparing them for consistency. Computer screens were run on share prices noting unusual price changes and unexpected prices. Another effective screen was to seek out unusually large dividend changes and unusual changes in rate of return. When these were discovered, data on individual securities were manually traced back to the original source to verify accuracy.

Although some errors may remain in the database, we are satisfied that it is very clean and can be used with a high degree of confidence.

\section{Sources of U.S. Data}

U.S. data used in this study were derived from two sources, a study by Ibbotson and Sinquefield and tapes from the Center for Research in Security Prices (CRSP).

Ibbotson and Sinquefield have produced a series of publications dealing with historical rates of return in U.S. capital markets $[14,25]$. These publications provide monthly returns for the 1926-86 period for common stocks, long-term U.S government bonds, long-term corporate bonds, and U.S. Treasury bills. They also provide data on the inflation rate in the United States. The common stock total returns provided by Ibbotson and Sinquefield are based on the Standard \& Poor's Composite Index, which 
includes both stock price changes and dividends. This index is a market value weighted average return of 500 of the largest companies (in terms of market value) in the United States. Before 1957 it was made up of 90 of the largest stocks.

CRSP data files were developed by the Center for Research in Security Prices at the Graduate School of Business of the University of Chicago. For the purposes of this study we employed the monthly equity index which is based on the monthly return for all stocks listed on the New York Stock Exchange. The index assumes reinvestment of dividends and is market-value weighted. The CRSP data were chosen for a number of Canadian/U.S. comparisons, because the Canadian series corresponds closely to it. It was also available for the entire 1950-86 period used in this study. Readers comparing the results of this study with the results published in our previous study will find that the CRSP data have undergone some changes. This is the result of periodic modifications made by CRSP as problems with their data are uncovered and new information is added. ${ }^{3}$

From time to time in the study we use either the Ibbotson and Sinquefield data or the CRSP data. In each case the source of the U.S. data is clearly noted.

\section{The Equity Total Return Series}

For the purposes of this study, it was decided to create a monthly equity total return index from among all stocks in the database. The securities included each month were those for which a beginning and ending price, dividends paid, and shares outstanding were available. Thus, the

${ }^{3}$ For a discussion of the development, accuracy, and changes in the CRSP files, see [26]. 
number of securities included varies from month to month, depending on data availability. It was decided to determine the monthly rate of return on a value-weighted basis. That is, the return for each security was weighted according to the relative market value of all outstanding shares of the security, compared with the total market value of all outstanding shares of all available securities. A value-weighted, as opposed to an equal-weighted, index was chosen because it more appropriately reflects changes in wealth of all equity investors as a group. 4

\section{INFLATION}

The real rate of return on an investment is the nominal return adjusted for changes in purchasing power over a period of time. The behavior of real rates of return are of concern to both investors and public policy analysts. Investors commonly seek out securities which will provide a hedge against inflation. In other words, they look for securities for which the return earned will be at least some real level, regardless of the general rate of inflation. Real returns are also used for model-building and economic forecasting purposes, for many types of investor and consumer behavior are related to real rather than nominal returns.

Both investors and economists are concerned about expected future (ex ante) real returns rather than historical (ex post) real returns. Unfortunately, it is very difficult to measure the expectations of investors. Consequently, economists typically make the simplifying assumption that realized returns are, on average, equal to the returns which investors expected. This leads to such comments as "investors are currently demanding a real return of 6

${ }^{4}$ See Lorie and Hamilton [17] for a detailed discussion of the types of choices involved in the creation of an index. 
percent," from analysts who have just observed that the ex post real rate for some recent period was 6 percent. An equally plausible explanation of this same phenomenon is that investors expected a real rate of 10 percent but inflation was 4 percent higher than anticipated, so the realized real rate was 6 percent. This notion of unanticipated inflation is increasingly being used by economists to explain observed real returns $[6,19]$.

A major consideration in measuring ex post real returns is the index used to measure changes in purchasing power. As a rule, a basket of goods and services is chosen, and the weighted-average price of purchasing this basket of goods is periodically measured. An index is created out of this series of weighted-average prices with some base period equal to 100. To represent price changes for purposes of this study, we chose the Canadian Consumer Price Index (CPI). This index measures the changes in retail prices of a basket of goods and services purchased by a representative cross section of the Canadian population. The CPI was chosen, rather than broader measures of prices, on the grounds that investors are ultimately concerned with the prices of goods they expect to purchase in the current period, rather than the prices of other items such as sheet steel or wheat. Fortunately, the various price indexes are highly correlated, so the real returns obtained are only slightly affected by the price index chosen. The CPI was obtained from Statistics Canada (Cansim D130000). It has a base of $1981=100$.

The rate of inflation for a given month was derived from the CPI as the ratio of the price index value in month $t$ to the price index in month $t-1$ and subtracting one. For example, if the index value was 102 at the end of month $t$, and the price index value at the end of month $t-1$ was 100 , the rate of inflation during the month would be $102 / 100-$ 
$1=.02$ or 2 percent. The inflation rate was derived from the $\mathrm{CPI}$ in this way for each month over the period January 1950-December 1987 inclusive. 


\section{Data Presentation and Analysis}

This chapter presents and analyzes the historical rates of return for several basic and derived series observed in Canada's capital market over the $1950-87$ period. A number of comparisons are made with rates of return in the U.S. market over the period 1950-86. This discussion is divided into the following sections:

Summary Return Data: nominal and real annual returns for all basic return series (Treasury bills, long-term Government of Canada bonds, provincial bonds, corporate bonds, municipal bonds, and equities).

Holding Period Returns: nominal and real return matrixes for all holding periods 1950-87 inclusive for all basic series.

U.S. Equity Holding Period Returns: nominal and real equity return matrixes for all holding periods 1950-86 inclusive, derived from CRSP and New York Stock Exchange data.

Statistical Characteristics of Basic Return Series: mean, high, low, standard deviation, skewness, and kurtosis of each basic return series and a comparison with U.S. return series. 
Correlations of Canadian Return Series: correlation between all pairs of basic return series.

Correlations of Canadian and U.S. Return Series Market Risk Premiums: inflation, default, and maturity premiums for all basic return series; comparison with U.S. premiums.

Standard Deviation of Equity Returns: 12-month moving standard deviation of equity returns from December 1950 to December 1987; comparison with U.S moving standard deviation of equity returns.

Returns of Small and Large Canadian Firms.

Canadian Betas: betas for a large sample of Canadian firms based on the five years ended December 31, 1987.

Behavior of TSE Subindexes: distribution of annual returns; correlations between subindexes; betas for subindexes.

The October 1987 Crash: daily returns for October; daily returns for 1987; subindex behavior during October.

\section{SUMMARY RETURN DATA}

\section{Annual Returns}

Table $5-1^{1}$ contains nominal annual return data for the six basic series as well as the Consumer Price Index for the 1950-87 period. Following the Korean War, the CPI exhibited a pattern of relatively low but slowly growing price inflation. In the 1970s, fueled by the OPEC oil crisis, prices accelerated rather dramatically. After peaking in 1981,

\footnotetext{
${ }^{1}$ Because of the large amount of data contained in the tables to this chapter, the tables are presented at the end of the chapter to facilitate the exposition.
} 
price increases slowed again to a relatively stable rate of approximately 4 percent.

It is apparent from the table that Treasury bill returns generally rose over the period along with the price level. The relation between security returns and the price level is not as clearcut for the other series.

Annual Treasury bill returns were all positive (only one of themonthly observations was negative), whereas all other securities had a negative return in at least one year. Although all bond series returns tend to move together, there is no obvious pattern to the timing of the years containing negative returns. Casual observation of the bond returns suggests that very large individual year returns were somewhat more prevalent after 1970 than in the two decades preceding 1970, but this pattern is not as apparent for equities. The $1975-80$ period was one of unprecedented substantial returns for equities, unmatched by other types of securities. No doubt many managers of diversified portfolios were hard pressed to justify a high proportion of bonds in their portfolios during that period. Conversely, the 1982-86 period was a bull market for bonds, whereas equity returns were somewhat erratic.

Real annual returns for each of the basic return series are contained in Table 5-2. Real returns are nominal returns deflated by the CPI. ${ }^{2}$

A number of significant patterns may be observed. First, Treasury bill real returns have gone through long periods of being positive (1959-70) and negative (1971-75). The ex post real return on Treasury bills has clearly increased in recent years. Over the 31-year period from 1950 to 1980 , the compound average real return was 0.23 percent,

\footnotetext{
${ }^{2}$ The computation of real returns is described in Appendix F.
} 
whereas it was 5.36 percent over the most recent seven years from 1981 to 1987.

Second, long-term bonds were a poor hedge against inflation over the late 1960 s and 1970 s. Over the 17 -year period from 1965 to 1981, real returns were negative in 14 years and positive only three times. Clearly this situation has improved in recent years, but it will be some time before fixed-income investors forget the erosion in real value that can occur in times of inflation. Some argue that this experience partially accounts for the high ex ante real returns currently demanded by fixed-income investors. Equities have been modestly more consistent in providing a positive real return. Comparison of Table 5-2 with the inflation rates in Table 5-1 indicates that negative real debt security returns seemed more likely to occur in years when there was an abnormally large increase in the rate of inflation (e.g., 1950, 1951, 1956, 1973, 1974, and 1977). This provides intuitive support for the notion that investors experience negative real returns if inflation occurs unexpectedly.

\section{Wealth Index}

Table 5-3 shows the amount to which a dollar invested as of December 1949 would have grown if it had been invested in each of the basic series. These calculations assume that all dividends or interest are reinvested, that there are no transaction costs associated with the reinvestment, and that no taxes are paid. From the table it is apparent that investment in equities would have provided the greatest growth in wealth, followed by investment in municipal bonds. When this study was last performed employing data up to 1983, Treasury bills recorded the second best performance, but the remarkable returns in the long bond market in recent years have resulted in an overall 
performance for municipal and industrial bonds which surpassed Treasury bills.

Table 5-4 shows real growth of a dollar invested in each of the basic series in December 1949. Note that for all but equities the increase in real wealth over the period was quite modest. In the 35-year period ending in 1984, there was a decline in the real wealth of an investor in only long-term Government of Canada bonds. Remember, these calculations are made on a before-tax basis.

Returning to Table 5-2, recall that the total nominal wealth from an investment in Treasury bills increased from $\$ 1.00$ to $\$ 8.83$ by the end of 1987 . If the tax rate on the $\$ 7.83$ increase in wealth from the Treasury bill portfolio was 25 percent in 1987, the real wealth increase from holding Treasury bills would have been close to zero. Of course, this example oversimplifies the tax situation, but illustrates that a modest level of taxes would have eliminated any real return from the Canadian fixed-income security markets.

\section{HOLDING PERIOD RETURNS}

Tables 5-5 to 5-17 contain compound annual rate of return data for various holding periods from 1950 to 1987 inclusive. Table 5-5 may be used to illustrate how to read these tables. The rate of return on Government of Canada Treasury bills over the one-year period January 1, 1950, to December 31, 1950 was 0.51 percent. The assumptions underlying this annual return calculation are discussed in Chapter 4 . Similarly, the annual return for 1951 was 0.71 percent and for 1952 was 0.95 percent. The table also allows the reader to see the compound annual rate of return (as opposed to the simple average annual return) for holding periods longer than one year. For example, the compound annual return over the period January 1, 1954, to December 31, 1982 was 5.98 percent. 
For each of the basic return series, a return matrix is provided in both nominal and real terms.

\section{U.S. EQUITY HOLDING PERIOD RETURNS}

Tables 5-18 and 5-19 display compound annual rate of return data for the U.S. equity market for holding periods from 1950 to 1986 inclusive. ${ }^{3}$ Table 5-18 contains nominal returns and Table 5-19 real returns. The data were derived from CRSP files. All returns were from the perspective of a Canadian investing in the United States, so they are adjusted for fluctuations in the value of the Canadian dollar. The data in Table 5-19 were adjusted using the Canadian CPI.

\section{STATISTICAL CHARACTERISTICS OF MONTHLY RETURN SERIES}

The key statistical features of each of the basic monthly return series are seen in Table 5-20. As one might expect, the equity series had a substantially higher mean and also a higher standard deviation and range than all of the other series. As also expected, the Treasury bill series had the lowest standard deviation and range. The high Treasury bill average yield relative to the Government of Canada long-term bond series was somewhat surprising, because it is commonly assumed that Treasury bills are associated with lower risk, and therefore should earn a lower equilibrium return than long-term bonds. ${ }^{4}$ These statistical

\footnotetext{
${ }^{3}$ The data end at 1986 because 1987 data were not available at the time of writing.

${ }^{4}$ Recall that our computation of Government of Canada Bond returns assumed a term of maturity of 17 years. Table $5-20$ shows that this assumption led to a standard deviation of the long Canada bond series of 0.0239 . Replication of the bond return computation assuming maturities varying from 14 to 25 years showed that there was no change in the mean bond return, but as the assumed maturity lengthened, the standard deviation grew from 0.0188 at 10 years to 0.0269 at 25 , thus leaving our conclusions essentially unchanged.
} 
properties are illustrated graphically for three of the basic series in Figure 5-1. This exhibit shows that as the mean return grows, the dispersion of monthly outcomes also grows.

It has frequently been observed that the distribution of returns on U.S. equity portfolios is approximately normal [4]. An analysis was conducted to see if this conclusion applied to the equity return series as well. Based on the observed mean and variance of the series, a theoretical normal distribution was created. Next, 10 equal intervals were created which encompassed all theoretical return values. Using these same intervals, the number of actual observations in each interval was noted. Then the cumulative probability distribution of the theoretical distribution was compared with the cumulative probability distribution of the actual observations. The point of maximum deviation between the theoretical and observed value was identified, and the size of the difference was noted. A Kolmogorov-Smirnov test of this difference was conducted to test the hypothesis that the two distributions were the same; in other words, to test the hypothesis that the observed values were normally distributed. Because the null hypothesis could not be rejected at the 5 percent level of significance, we are to conclude that the returns were consistent with a normal distribution. Nonetheless, the data in Table 5-20 suggest that returns on the portfolio of equities are modestly skewed to the left, which means that extremely low returns are observed more frequently than are extremely high returns. Also, the equity return data seem to have a greater kurtosis (peakedness) than expected from a normal distribution. A follow-up analysis similar to the one above rejected the hypothesis that the equity return series was log-normally distributed. It is important to note that this conclusion relates to the 


\section{FIGURE 5-1}

\section{FREQUENCY DISTRIBUTIONS OF CANADIAN EQUITIES, INDUSTRIAL BONDS, AND TREASURY BILIS MONTHLY RATES OF RETURN}

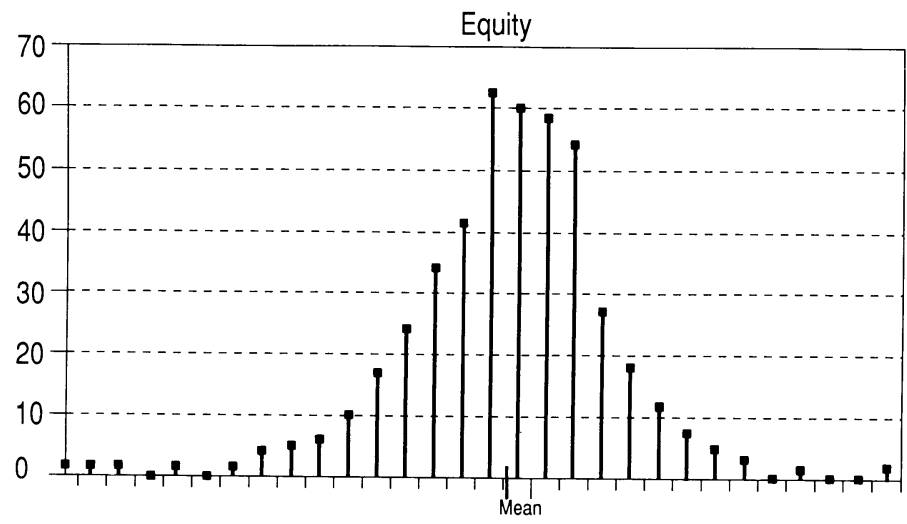

-0.20 to 0.19 by increments of 0.013

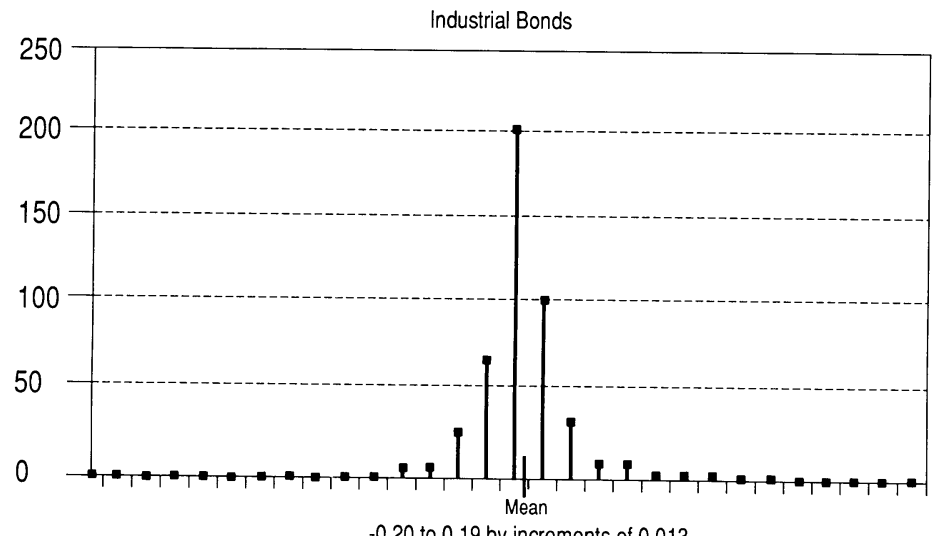

-0.20 to 0.19 by increments of 0.013

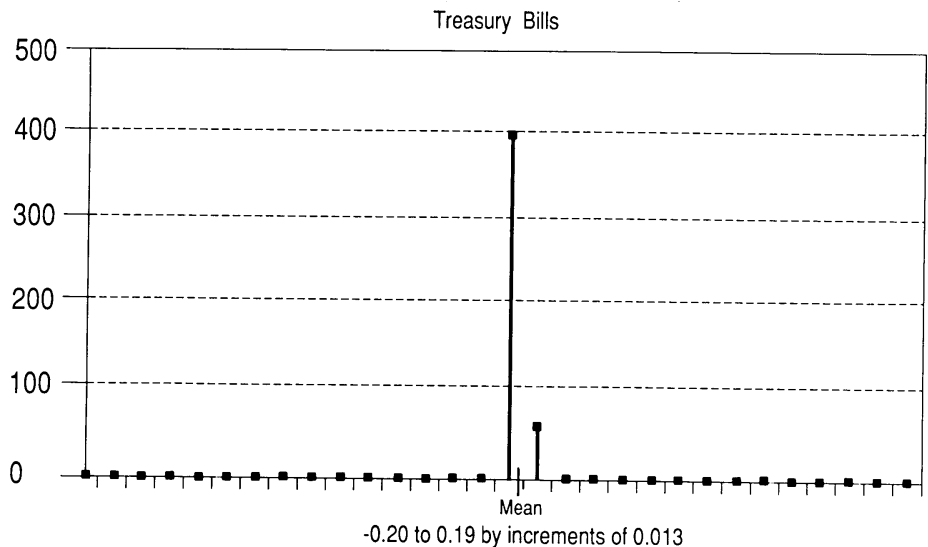


distribution of returns of a portfolio rather than the distribution of individual security returns.

Turning to the fixed-income series, it was apparent that all of these series had a much higher level of skewness (to the right in this case) and kurtosis, than the equity series. For all of these series, as well as the inflation rate series, the hypothesis of an underlying normal distribution was rejected.

Although portfolio equity returns may be normally distributed, it has been asserted that the returns on individual equities are slightly skewed to the right, and have fatter tails than expected from a normal distribution [4]. To address this issue, the monthly return distributions of 728 stocks in the data base were observed. These stocks were selected based on one simple criterion: the availability of at least 100 monthly return observations. Using the Kolmogorov-Smirnov test described earlier, it was determined that at the 5 percent significance level, the hypothesis of normality for 612 of the 728 stocks was rejected.

Monthly return data for the United States over the period 1950 to 1986 were available from the Ibbotson-Sinquefield studies discussed in Chapter 4. ${ }^{5}$ Table 5-21 compares the basic Canadian monthly return series with these data. To allow proper comparison, all U.S. returns were adjusted for changes in the exchange rate between the Canadian and U.S. dollar. This means that the realized returns are for a Canadian investor purchasing U.S. securities with Canadian dollars at the beginning of the period, and selling them for Canadian dollars at the end of the period.

${ }^{5}$ It is important to note that this equity series is different from the CRSP series discussed in Chapter 4. 
The data in Table 5-21 show a very similar mean return for the equity markets in the two countries. On an annualized basis, the Canadian arithmetic average return is 12.92 percent whereas the U.S. return is 14.20 percent. The higher U.S. return was somewhat surprising, as the U.S. market is generally thought to be less risky than the Canadian market. ${ }^{6}$ This notion of lower risk in the U.S. was supported by the lower range and standard deviation of the U.S. equity return series. The mean rates of return for the debt series were all higher in Canada, perhaps reflecting Canada's commonly-espoused need to keep interest rates high to attract capital. Note, however, that inflation rates were very similar in the two countries.

An interesting question at this point is: Has the exchange-rate adjustment significantly affected the characteristics of the U.S. return series? To answer this question, the analysis in Table 5-21 was repeated for the U.S. data without the exchange adjustment. The results are shown in Table 5-22. In general, the exchange-adjustment calculation had the effect of increasing both the mean return and the standard deviation of each series. The increase in standard deviation was particularly pronounced for the Treasury bill and CPI series.

\section{CORRELATIONS BETWEEN CANADIAN RETURN SERIES}

Table 5-23 contains a correlation matrix for the basic monthly return series over the $1950-87$ period. As one would expect, the four long-term bond series were highly correlated with each other. Equity returns were modestly

\footnotetext{
${ }^{6}$ One should be cautious in concluding that returns in Canada are either greater or less than those in the United States, because empirical results depend significantly on the time period examined and the type of index chosen.
} 
correlated with long-term bond returns, but not with the price level or Treasury bill returns. Of all the series, Treasury bills had the highest correlation with the inflation rate.

For each of the basic series, the serial correlations (that is, correlation between the current value of the series and some past value of the series) were computed. Lags of from one to twelve periods were used. In general, the results for equities, along with Government of Canada, industrial, municipal, and provincial bonds, suggested little serial correlation for all lags. The correlations were sometimes positive and sometimes negative, but there was no apparent pattern. The largest coefficient for each period was approximately plus or minus 0.10 . The CPI return series exhibited positive serial correlation for all twelve lags. The highest correlation coefficient was 0.46 for a twelve-month and a one-month lag; the smallest was 0.32. By far the greatest serial correlation was exhibited in the Treasury bill return series. The correlation was large and positive for all lags. The maximum correlation of 0.94 occurred with a lag of one month, and the lowest serial correlation was 0.77 with a lag of twelve months. This result was somewhat surprising, but indicative of a strong trend in the data.

\section{CORRELATIONS BETWEEN U.S. AND CANADIAN RETURN SERIES}

Table 5-24 illustrates the results of computing the correlations between U.S. (Ibbotson-Sinquefield and CRSP) and Canadian monthly return series. The time period covered for all series was 1950-86. As expected, each Canadian series was positively correlated with its comparable U.S. series. For example, U.S. and Canadian bond returns were correlated, as were the returns on U.S. and Canadian Treasury bills. The lowest correlation 
between such pairs of series was between U.S. and Canadian inflation rates at 0.22 , and the highest correlation was between U.S. (CRSP) and Canadian equities at 0.75 . This correlation was similar to the correlation of 0.71 obtained by Ibbotson, Carr, and Robinson [13] in a study covering the $1960-80$ period.

Both Canadian and U.S. equity returns are modestly positively correlated with long-term bond returns in their respective countries, and had a low correlation with the inflation rate. In both the U.S. and Canada, the two long-term bond series (governments and industrials) were correlated with each other; in both the U.S. and Canada, the long-term bond series were positively correlated with Treasury bill returns. The only series which was substantially correlated with inflation in each country was the Treasury bill return series. The two U.S. equity return series (Ibbotson-Sinquefield and CRSP) were highly correlated. Consequently, results from the two series were quite similar.

To gauge the impact of the exchange-rate adjustment on the pattern of correlations the correlation matrix in Table 5-24 was recomputed without the exchange-rate adjustment. The results were generally quite similar. For example, the correlation between U.S. and Canadian equity returns rose from 0.75 to 0.77 when the exchange-rate adjustment was removed. An exception to this pattern was with Treasury bills. The correlation between U.S. and Canadian Treasury bills rose dramatically from 0.29 to 0.88 when the exchange-rate adjustment was removed.

It is quite common for analysts to assume that prices, and therefore returns, in the Canadian capital market lag behind those in the United States. As a preliminary test of this hypothesis, a correlation matrix was estimated for all series of the current month's Canadian return with the return in 
the immediately preceding month in the United States. The results are shown in Table 5-25.

Consistent with a random walk notion, there was very little correlation between the lagged values of most series. For example, the correlation between the U.S. equity market in period $\mathrm{t}-1$ and the Canadian equity market in period $t$ was -0.01 . On the other hand, both the Treasury bill and CPI series was somewhat correlated at 0.20 and 0.22 respectively. As noted earlier, this is consistent with the general upward trend of these series for the period under consideration.

Because these correlations were estimated using monthly data, they are not a strong test of the hypothesis that U.S. return series lead Canadian return series. Most analysts would say that if the two capital markets move in tandem, they do so on an hourly or daily basis, and monthly data are perhaps too gross to capture this relation.

\section{CANADIAN MARKET RISK PREMIUMS}

It is common to think of the return on a security as made up of several components-the real rate, the expected level of inflation, a maturity premium, and a default premium. Table 5-26 provides an ex post measure of these four components for the basic series based on both the annual arithmetic mean return and the annual geometric mean return. Most of the following discussion employs arithmetic average returns.

The real rate of return is commonly measured by subtracting the ex post inflation rate from the ex post Treasury bill return. The average annual inflation rate over the $1950-76$ period was 4.76 percent, and the average annual 
Treasury bill rate was 5.98 percent, making the average real rate 1.22 percent. $^{7}$

It is commonly assumed that the return on a long-term investment is normally higher than the rate of return on a short-term investment. To measure this maturity premium, the rate of return on short-term Government of Canada bonds was subtracted from the rate of return on long-term Government of Canada bonds. As shown in Table 5-26, this maturity premium was a negative 0.34 percent. This negative maturity premium is not a recent phenomenon. Over other periods, the maturity premium was also negative. An interesting question for future study is whether the maturity premium rose following the Government of Canada debt refunding operation of 1958, which increased the supply of long-term bonds in the market.

The greater the default risk, the greater the premium demanded by the market. In Table 5-26, this default premium was measured by subtracting the return on the presumably default-free long Canada bonds from the return on other securities, which presumably have some possibility of default. The table shows that the default premium for provincial bonds was 0.59 percent and, consistent with expectations, was higher, 1.08 percent, for municipal bonds. The 0.98 risk premium for industrial bonds was modestly lower. Also, as one might expect, the

${ }^{7}$ Strictly speaking, the real rate of return is obtained as follows:

Real Rate $=\frac{1+\text { Nominal Rate }}{1+\text { Inflation Rate }}-1$

Thus, in this illustration we are only approximating the real rate which, calculated as above for Treasury bills, would be 1.16 percent. 
equity risk premium of 6.86 percent was higher than the risk premium for any of the fixed-income instruments.

Although the average equity risk premium was substantial over a 38-year period, it is also apparent that in some periods the ex post equity risk premium has been negative, and that good years have tended to offset bad years in the equity market. How long would one have to commit funds to the equity market to be quite confident that the equity risk premium would be positive (that is, that equities would provide a higher return than long-term Government of Canada bonds)? To provide a partial answer to this question, the five-year compound annual return on Government of Canada bonds was compared to the five-year compound average return on equities for all five-year periods ending December 31, 1954-December 31, 1987. For these 34 observations, the equity default risk premium was positive in all but seven of the five-year periods: 1969-73 $(-0.73), 1970-74(-7.71), 1972-76(-0.78), 1973-77(-4.22)$, $1980-84(-3.03), 1981-85(-7.99)$, and 1982-86 (-7.13). Thus, it seems that if the past is representative of the future, a buy-and-hold investor with a horizon of five years or more would have a relatively high probability of achieving an equal or superior return from an equity portfolio compared with a government bond portfolio.

Table 5-27 provides a comparison of U.S. and Canadian premiums over the 1950-86 period using arithmetic returns. The U.S. data were taken from Ibbotson and Sinquefield and adjusted for changes in the value of the Canadian dollar. The series show similar inflation rates and real returns. The equity risk premiums were quite different between the two countries. Recall that the Canadian equity risk premium was defined as the difference between the long government return and the equity return in each country. Ibbotson and Sinquefield, in their publications, compute this premium 
somewhat differently, by subtracting the Treasury bill return from the equity return. Using this measure, the Canadian equity risk premium was 7.00, whereas the U.S. equity risk premium was 8.35 .

\section{STANDARD DEVIATION OF EQUITY RETURNS}

As we have seen, investors are concerned with both expected return and the risk surrounding it. For holders of diversified portfolios, a measure of risk is the standard deviation. A common research question posed (Fama, Officer, and others) is whether the variability of equity returns has changed over time. To shed light on this question, a 12-month moving average standard deviation of monthly stock returns was computed. ${ }^{8}$ Table $5-28$ provides the results for the 12-month period ending in December for each year from 1950 to 1987. Casual observation of the results suggests that the standard deviation of monthly returns was high by historical standards in the 1980s. The dramatic increase in the standard deviation in 1987 may likely be attributed to the October market crash.

As a further check on these results, a similar 12-month moving average standard deviation was calculated for U.S. data for the December 1950-December 1986 period using the CRSP market value index and the Ibbotson-Sinquefield market value index described in Chapter 4 . These results are also contained in Table 5-28. Comparison of the three series showed that they moved together and that except for 1985 and 1986, the Canadian standard deviation appeared marginally higher than that for the U.S. data.

A classic study (Officer [22]) of U.S. return variability covering the period 1897-1969 demonstrated that the standard deviation of equity returns increased dramatically 
during the depression and pre-World War II years, but returned to more normal levels after the war. Comparison of U.S. results with Officer's revealed that, whereas in the 1970s and 1980s the standard deviation appeared high relative to the 1950-70 period, it was still much lower than during the peak pre-war period.

An analysis of moving standard deviations was conducted using the Canadian debt series. The results were similar to those for the Canadian equity series, with 1980-82 standard deviations reaching abnormally high levels relative to other observations over the $1950-87$ period.

\section{RETURNS OF SMALL AND LARGE FIRMS}

Recent capital market research suggests that the returns obtained from the equities of small firms are larger than those from the equities of large firms [13]. Moreover, it appears that the extra return provided by small firms more than compensates the investor for the extra risk taken. To shed additional light on this controversy, a detailed analysis was conducted of the return of a sample of small and large firms in the data base.

The analysis was conducted on all stocks in the data base covering the period February 1, 1950-December 31, 1987. For a given year, such as the year ended December 1949, the total dollar value of each outstanding security as of the end of the year (price per share times number of shares outstanding) was computed. Two portfolios were then formed, the first consisting of the 50 percent of all stocks which had the highest dollar value outstanding, and the second consisting of the remaining stocks which had the lowest dollar value outstanding. The first group was the large-firm portfolio and the second was the small-firm portfolio. The monthly rate of return for each portfolio was then computed over the following one-year period. For 
example, if data at the end of December 1949 were used to identify the securities as large or small, then the year over which the actual monthly return was measured was $1950 .^{9}$ In the second year (for example, 1951) the firms were all reclassified as large or small and the monthly returns were again calculated. Through a repetition of this process, a series of 456 monthly returns was derived for each of the two portfolios.

The rates of return on the two portfolios for each month were derived in two different ways: employing both market-value weights and equal-value weights. Table 5-29 provides summary statistics for the two portfolios under each computational technique.

The argument in favor of market-value weights for a rate of return series is that the series best reflects the impact on the wealth of all investors as a group. Part A of Table 5-29 shows the key monthly return characteristics of the value-weighted series. It is apparent from the data that the small firms as a group earned a higher average return and had a higher degree of month-to-month variability of return than was exhibited by the large-firm portfolio. As one would expect, because of the use of value weights, the large firm and total equity series are very comparable.

Part B of the table gives the results derived from the use of equal weights for all securities. Because small firms seem to have higher returns than large firms, it is not surprising to find that equal weighting provided a portfolio return higher than value weighting. Furthermore, the superiority of the small-firm portfolio over the large-firm portfolio was even more pronounced.

\footnotetext{
${ }^{9}$ This approach was used to avoid a potential bias which could have been introduced if data from the same or immediately adjoining years had been used both to classify the stocks and to measure the observed return.
} 
The data in both panels suggest that the skewness of the two portfolios was modest, but the large-firm portfolio tended to be skewed to the left and the small-firm portfolio tended to be skewed to the right. The small-firm portfolios generally exhibited greater kurtosis. There was little evidence of serial correlation for either sample.

A matrix of holding-period returns for small- and large-firm portfolios using value weights is contained in Tables 5-30 and 5-31; the returns using equal weights are in Tables 5-32 and 5-33.

\section{BETAS}

With the development of modern portfolio theory, it has become increasingly apparent that the standard deviation may be an inadequate measure of the riskiness of individual securities. An alternative measure commonly proposed is a stock's beta derived by regressing the return of the stock on the observed market return. ${ }^{10}$ Betas are not widely available in Canada; therefore it was decided to generate betas for a subset of the stocks in the data base.

Because betas may be computed in a number of ways, it is important to specify how the following betas were calculated. To make the results as current as possible, betas were computed based on the 60 -month period ending in December 1987. Betas were calculated for any stock for which there were no more than 12 missing observations over that time period. For each of the qualifying stocks a regression was run of the form:

$\ln \left(1+R_{s, t}-R_{f, t}\right)=A_{s}+B_{s}\left[\ln \left(1+R_{m, t}-R_{f, t}\right)\right]+e_{s, t} ; t=1, \ldots, 60$

\footnotetext{
${ }^{10}$ For a discussion of the conceptual framework underlying the derivation and usefulness of beta, see James E. Hatch and Michael Robinson [11].
} 
where

$$
\begin{aligned}
\mathrm{R}_{\mathrm{s}, \mathrm{t}}= & \text { rate of return on security } \mathrm{s} \text { for month } \mathrm{t} ; \\
\mathrm{R}_{\mathrm{f}, \mathrm{t}}= & \text { the monthly Treasury bill rate of return for period } \\
\mathrm{t} ; & \\
\mathrm{R}_{\mathrm{m}, \mathrm{t}}= & \text { the market-weighted average rate of return on all } \\
& \begin{array}{l}
\text { stocks in the data base for period } \mathrm{t} \text { computed as } \\
\text { described in the Appendix; }
\end{array}
\end{aligned}
$$

$$
\begin{aligned}
& A_{s}, B_{s}=\text { regression parameters for each security, } s ; \text { and } \\
& e_{s, t}=\text { residual or firm-specific component of returns. }
\end{aligned}
$$

The quantities $R_{s, t}-R_{f, t}$ and $R_{m, t}-R_{f, t}$ are, respectively, the excess returns of the individual stocks and of the market. The results of these regressions are presented in Table 5-34.

The first data column gives the average monthly total rate of return for the security. Thus, the average monthly rate of return for Abitibi-Price over the 60-month period 1983-87 was 0.039 percent or roughly 58 percent per year. The average monthly value for all stocks in this sample was 0.0165 , so Abitibi earned an above-average return by a substantial margin.

The second column contains the beta or market sensitivity of the stock. It is simply the slope of the linear regression ( $\mathrm{B}_{\mathrm{S}}$ in the preceding equation). Abitibi's beta of 0.698 was below the sample average, which was 1.020 , and below the average beta for all securities in the data base.

The third column contains the standard error of the beta. The standard error is used to assess statistical significance and to establish confidence intervals for the estimated beta. 
If the returns data are normally distributed, there is a 95 percent chance that the true beta lies within plus or minus two standard errors of the estimated beta. Of course, all other things being equal, the smaller the standard error, the smaller the range for a given confidence level. In the case of Abitibi-Price, the standard error was 0.329. This means that there is a 95 percent chance that the true beta lies within two standard errors $(2 \times 0.329=0.658)$ of 0.698 ; that is, we are confident the true beta lies somewhere in the range $0.698 \pm 0.658$, or between 0.040 and 1.356 . Clearly this is a very broad confidence interval, and should leave us uncomfortable about using 0.698 as our estimate of the true beta for this stock.

The fourth column contains the coefficient of determination-usually labelled R-squared. This statistic indicates how much of the variation in the individual stock's return is explained by variation in the market's return. For example, in the case of Abitibi-Price, 0.073 or 7.3 percent of the variation in monthly excess return is explained by movement in the overall market, whereas 92.7 percent of the monthly excess return variation remains unexplained. The explained variation is often called systematic risk, and the unexplained variation is known as unsystematic or diversifiable risk. The average $\mathrm{R}$-squared for all stocks in the sample was 0.185 . This value was much lower than that computed using data over the 1982-86 period, for which it was 0.364 and lower than that reported in U.S. studies. We believe these results are attributable to the October crash.

The last column contains the variance for each stock. It reflects the spread of observed individual stock returns away from the average return for that stock and is used as a measure of total risk. The variance for Abitibi was 0.00903 whereas the average variance for all stocks in the sample was 0.02264 . 


\section{TORONTO STOCK EXCHANGE SUBINDEXES}

To this point, the study has been concerned exclusively with the characteristics of the TSE/Western data base. Many investors, however, rely on the various indexes produced by the Toronto Stock Exchange as indicators of market conditions. The purpose of this section is to provide selected data on the TSE 300 price index and its 14 subindexes.

The TSE 300 price index system was created in January 1977. ${ }^{11}$ It is a composite index of 300 stocks subdivided into 14 group subindexes on the basis of Standard Industrial Classification codes. From among all stocks listed on the exchange, stocks were chosen that belonged to Canadian firms, which were listed over three years, had a total market value of float ${ }^{12}$ or at least $\$ 3$ million, had an annual trading volume of at least 25,000 shares, and had a total market value of trading of at least $\$ 1$ million per year. From among this set of stocks, the exchange selected the top 300 stocks chosen on the basis of total market value of outstanding float. Using these stocks, the exchange computes a market float-weighted price index and a market float-weighted total value index. Once a year, the stocks in the index are reassessed for eligibility and a number of changes are made. When this index system was created in 1977, the exchange gathered data on the stocks in the various indexes back to February 1956 . This was accomplished by taking the stocks in the index as of 1977 and tracing them in time until they disappeared. Because of new listings, mergers, and other

\footnotetext{
${ }^{11}$ For a detailed description of the TSE Index System, see [11].

${ }^{12}$ The float is defined for purposes of this index as the total shares outstanding after removal of all control blocks. A control block is defined as a holding of over 20 percent of outstanding shares.
} 
events, the number of stocks in the indexes in earlier years was substantially less than 300 .

Table 5-35 shows the statistical characteristics of the TSE 300 price index and its 14 subindexes over the period 1956-87. These results must be interpreted with care, because (1) of the method of creating the indexes described above is flawed; (2) in the early years there were fewer stocks in the TSE 300; and (3) some of the subindexes contained relatively few stocks. The lowest average return over this period was realized by Utilities and the highest return was attained by the Gold \& Silver stocks, followed closely by Real Estate \& Construction. As one might have expected, the groups registering the highest returns also tended to have the greatest month-to-month variability: Gold \& Real Estate had the highest standard deviations and Utilities the lowest. As befits its high degree of diversification, the TSE 300 records one of the lowest degrees of variability.

Market timers often argue that stocks, in particular industry groups, go through phases when they may be expected to outperform the market, and phases when they may be expected to underperform the market. The movement of the stocks in an industry class relative to the market may be represented by its beta. The betas for various industries based on the 60 months ending in December 1987 are shown in Table 5-36. These data show that industries such as Metals \& Minerals (beta 1.44) and Paper \& Forest Products (beta 1.27) tended to outperform the market when the market as a whole was rising, whereas industries such as Pipelines (beta 0.72) and Financial Services (beta 0.80 ) tended to lag behind. Conversely, in a down market, the industries with a high beta tended to do worse than the market, and industries with a low beta 
tended to do better. In this sense, the low-beta industries may be viewed as defensive.

Some of the subindexes tended to move together whereas others did not. Table 5-37 contains a correlation matrix showing the co-movement of the returns of the various indexes. One of the most noticeable aspects of the table is that Gold \& Silver and Real Estate \& Construction had a low correlation with the TSE 300 . Indeed, Real Estate \& Construction had an extremely low correlation with all other industry groups. Gold \& Silver was another industry which was only modestly correlated with the other industries.

\section{THE OCTOBER 1987 CRASH}

No discussion of market returns would be complete without providing data on the October 1987 stock market crash and Black Monday.

As seen in Table 5-38, the TSE 300 price index declined steadily throughout the month of October 1987, culminating in a decline of 11.32 percent on Monday, October 19. This was followed by a decline of almost 7 percent on the following day for a two-day total of 18 percent. During the month, declining days exceeded rising days by a margin of 16 to 5 .

Table 5-39 places the crash into a longer-run perspective. It shows that returns were generally positive in the first seven months of 1987, with the market climbing over 25 percent. The market then weakened somewhat in August and September before its dramatic decline in October. By the end of the year, the market had recovered somewhat, so that the year as a whole registered a slightly positive return. Results for January and February of 1988 were quite flat. 
An interesting question in light of the preceding discussion is how the various industry sectors behaved during the crash. As seen in Table 5-40, the subindexes which fell most dramatically on Black Monday were Management Companies (-17.20 percent) and Transportation (-17.17 percent), with Paper \& Forest Products (-14.47) and Metals \& Minerals (-14.83) big losers as well. On Tuesday, Metals \& Minerals (-14.34) continued its steep decline, but was outpaced by a dramatic decline in the Gold \& Silver index $(-19.97)$. For the month as a whole, the biggest loser was Gold \& Silver, which lost over 35 percent of its value, followed by Metals \& Minerals $(-30.62)$ and Forest Products (-29.34). The sector which resisted the decline most effectively was Utilities $(-7.21)$, whereas Pipelines (-16.90) and Financial Services (-18.81) also were standouts. In general, the industry groups which had low betas in the period preceding the market decline performed the best, and those with high betas performed the worst. 
TABLE 5-1

NOMINAL ANNUAL RETURNS FOR BASIC RETURN SERIES 1950 TO 1987

\begin{tabular}{|c|c|c|c|c|c|c|c|}
\hline Year & $\begin{array}{c}\text { Treasury } \\
\text { Bills } \\
\end{array}$ & $\begin{array}{l}\text { Long } \\
\text { Canada } \\
\text { Bonds }\end{array}$ & $\begin{array}{c}\text { Provincial } \\
\text { Bonds }\end{array}$ & $\begin{array}{c}\text { Municipal } \\
\text { Bonds }\end{array}$ & $\begin{array}{c}\text { Industrial } \\
\text { Bonds }\end{array}$ & Equities & C.P.I. \\
\hline 1950 & 0.51 & -0.11 & -0.00 & 3.39 & 2.68 & 27.91 & 6.10 \\
\hline 1951 & 0.71 & -3.01 & -7.92 & -10.36 & -6.44 & 25.50 & 10.73 \\
\hline 1952 & 0.95 & 2.05 & 4.92 & 6.58 & 4.49 & 1.17 & -1.73 \\
\hline 1953 & 1.54 & 3.76 & 5.24 & 6.00 & 3.99 & -8.28 & -0.00 \\
\hline 1954 & 1.62 & 9.78 & 13.43 & 13.83 & 10.34 & 43.61 & 0.35 \\
\hline 1955 & 1.22 & -0.43 & -2.65 & 0.14 & 2.18 & 24.11 & 0.35 \\
\hline 1956 & 2.63 & -3.54 & -9.75 & -11.10 & -7.58 & 8.81 & 3.15 \\
\hline 1957 & 3.76 & 6.60 & 10.40 & 9.52 & 7.58 & -20.64 & 2.03 \\
\hline 1958 & 2.27 & -5.82 & -1.47 & 2.24 & 2.99 & 30.67 & 2.66 \\
\hline 1959 & 4.39 & -4.44 & -4.94 & -6.74 & -4.28 & 2.28 & 1.29 \\
\hline 1960 & 3.66 & 6.88 & 10.84 & 13.26 & 11.94 & 1.49 & 1.28 \\
\hline 1961 & 2.86 & 9.75 & 9.35 & 10.97 & 8.91 & 34.09 & 0.32 \\
\hline 1962 & 3.81 & 3.16 & 4.66 & 5.09 & 4.95 & -7.56 & 1.57 \\
\hline 1963 & 3.58 & 4.59 & 4.50 & 4.77 & 5.38 & 14.18 & 1.86 \\
\hline 1964 & 3.73 & 6.74 & 7.08 & 6.97 & 4.71 & 24.69 & 1.82 \\
\hline 1965 & 3.79 & 1.04 & 0.26 & 0.81 & -0.58 & 5.75 & 2.98 \\
\hline 1966 & 4.89 & 1.72 & -1.32 & -0.79 & -1.53 & -5.24 & 3.48 \\
\hline 1967 & 4.38 & -2.27 & 0.12 & -1.11 & -0.34 & 20.29 & 4.20 \\
\hline 1968 & 6.22 & -0.62 & 1.58 & 2.19 & 2.43 & 23.55 & 4.03 \\
\hline 1969 & 6.83 & -2.36 & -2.87 & -4.40 & -1.04 & -1.32 & 4.65 \\
\hline 1970 & 6.89 & 22.70 & 18.77 & 18.97 & 13.97 & -2.65 & 1.48 \\
\hline 1971 & 3.86 & 11.79 & 13.33 & 17.54 & 14.48 & 11.27 & 4.87 \\
\hline 1972 & 3.44 & 1.59 & 6.85 & 5.47 & 9.51 & 30.16 & 5.10 \\
\hline 1973 & 4.78 & 1.96 & 1.01 & 2.48 & 2.40 & -3.72 & 9.27 \\
\hline 1974 & 7.68 & -0.98 & -2.43 & -4.17 & -5.86 & -27.02 & 12.32 \\
\hline 1975 & 7.05 & 2.74 & 7.14 & 7.10 & 8.35 & 22.18 & 9.53 \\
\hline 1976 & 9.10 & 19.65 & 21.35 & 25.00 & 23.32 & 11.72 & 5.91 \\
\hline 1977 & 7.64 & 6.19 & 9.02 & 8.50 & 10.58 & 15.44 & 9.46 \\
\hline 1978 & 7.90 & 1.47 & 3.77 & 5.00 & 5.16 & 29.36 & 8.36 \\
\hline 1979 & 11.05 & -2.77 & -2.87 & -2.20 & -1.55 & 50.56 & 9.80 \\
\hline 1980 & 12.16 & 2.46 & 2.97 & 1.58 & 2.93 & 28.05 & 11.19 \\
\hline 1981 & 19.09 & -2.02 & -2.37 & 0.51 & -0.78 & -10.89 & 12.10 \\
\hline 1982 & 15.25 & 45.81 & 45.99 & 45.23 & 43.35 & 4.07 & 9.26 \\
\hline 1983 & 9.45 & 9.69 & 10.47 & 10.86 & 13.89 & 36.04 & 4.55 \\
\hline 1984 & 11.21 & 16.43 & 18.11 & 18.99 & 18.86 & 0.37 & 3.76 \\
\hline 1985 & 9.71 & 26.10 & 26.07 & 24.32 & 24.25 & 24.79 & 4.35 \\
\hline 1986 & 9.34 & 17.70 & 16.55 & 16.50 & 11.59 & 12.19 & 4.17 \\
\hline 1987 & 8.17 & 0.59 & 1.66 & 2.31 & 6.19 & -0.28 & 4.15 \\
\hline
\end{tabular}


TABLE 5-2

\section{REAL ANNUAL RETURNS FOR BASIC RETURN SERIES 1950 TO 1987}

\begin{tabular}{|c|c|c|c|c|c|c|}
\hline Year & $\begin{array}{c}\text { Treasury } \\
\text { Bills } \\
\end{array}$ & $\begin{array}{l}\text { Long } \\
\text { Canada } \\
\text { Bonds } \\
\end{array}$ & $\begin{array}{c}\text { Provincial } \\
\text { Bonds }\end{array}$ & $\begin{array}{c}\text { Municipal } \\
\text { Bonds }\end{array}$ & $\begin{array}{c}\text { Industrial } \\
\text { Bonds }\end{array}$ & Equities \\
\hline 1950 & -5.26 & -5.85 & -5.75 & -2.55 & -3.22 & 20.56 \\
\hline 1951 & -9.04 & -12.41 & -16.84 & -19.05 & -15.51 & 13.34 \\
\hline 1952 & 2.73 & 3.84 & 6.77 & 8.45 & 6.33 & 2.95 \\
\hline 1953 & 1.54 & 3.76 & 5.24 & 6.00 & 3.99 & -8.28 \\
\hline 1954 & 1.26 & 9.40 & 13.03 & 13.43 & 9.95 & 43.10 \\
\hline 1955 & 0.87 & -0.78 & -2.99 & -0.21 & 1.82 & 23.68 \\
\hline 1956 & -0.05 & -6.49 & -12.50 & -13.81 & -10.40 & 5.49 \\
\hline 1957 & 1.69 & 4.48 & 8.20 & 7.34 & 5.44 & -22.22 \\
\hline 1958 & -0.38 & -8.25 & -4.02 & -0.41 & 0.32 & 27.29 \\
\hline 1959 & 3.05 & -5.66 & -6.15 & -7.94 & -5.50 & 0.97 \\
\hline 1960 & 2.35 & 5.53 & 9.44 & 11.83 & 10.53 & 0.21 \\
\hline 1961 & 2.54 & 9.41 & 9.01 & 10.62 & 8.57 & 33.67 \\
\hline 1962 & 2.20 & 1.56 & 3.04 & 3.46 & 3.32 & -8.99 \\
\hline 1963 & 1.69 & 2.68 & 2.59 & 2.86 & 3.46 & 12.10 \\
\hline 1964 & 1.87 & 4.83 & 5.16 & 5.05 & 2.84 & 22.46 \\
\hline 1965 & 0.78 & -1.89 & -2.65 & -2.11 & -3.47 & 2.68 \\
\hline 1966 & 1.36 & -1.70 & -4.64 & -4.12 & -4.84 & -8.42 \\
\hline 1967 & 0.17 & -6.21 & -3.92 & -5.09 & -4.36 & 15.44 \\
\hline 1968 & 2.10 & -4.48 & -2.36 & -1.77 & -1.54 & 18.77 \\
\hline 1969 & 2.08 & -6.70 & -7.19 & -8.65 & -5.44 & -5.70 \\
\hline 1970 & 5.33 & 20.91 & 17.04 & 17.23 & 12.31 & -4.07 \\
\hline 1971 & -0.96 & 6.61 & 8.07 & 12.09 & 9.16 & 6.11 \\
\hline 1972 & -1.59 & -3.34 & 1.66 & 0.35 & 4.19 & 23.84 \\
\hline 1973 & -4.11 & -6.69 & -7.56 & -6.22 & -6.29 & -11.89 \\
\hline 1974 & -4.13 & -11.85 & -13.13 & -14.69 & -16.19 & -35.02 \\
\hline 1975 & -2.27 & -6.20 & -2.18 & -2.22 & -1.08 & 11.55 \\
\hline 1976 & 3.01 & 12.97 & 14.57 & 18.02 & 16.44 & 5.49 \\
\hline 1977 & -1.66 & -2.99 & -0.40 & -0.87 & 1.02 & 5.46 \\
\hline 1978 & -0.42 & -6.36 & -4.23 & -3.10 & -2.95 & 19.39 \\
\hline 1979 & 1.13 & -11.45 & -11.55 & -10.93 & -10.34 & 37.12 \\
\hline 1980 & 0.87 & -7.85 & -7.39 & -8.64 & -7.43 & 15.16 \\
\hline 1981 & 6.24 & -12.60 & -12.91 & -10.34 & -11.49 & -20.51 \\
\hline 1982 & 5.47 & 33.44 & 33.61 & 32.92 & 31.19 & -4.76 \\
\hline 1983 & 4.69 & 4.93 & 5.67 & 6.04 & 8.94 & 30.12 \\
\hline 1984 & 7.18 & 12.21 & 13.82 & 14.68 & 14.55 & -3.27 \\
\hline 1985 & 5.14 & 20.85 & 20.81 & 19.13 & 19.07 & 19.59 \\
\hline 1986 & 4.96 & 12.98 & 11.88 & 11.84 & 7.12 & 7.70 \\
\hline 1987 & 3.86 & -3.42 & -2.39 & -1.77 & 1.96 & -4.26 \\
\hline
\end{tabular}


TABLE 5-3

\section{INDEX OF NOMINAL WEALTH FOR MAJOR SERIES, $1949=1.00$ 1950 TO 1987}

\begin{tabular}{|c|c|c|c|c|c|c|c|}
\hline Year & $\begin{array}{c}\text { Treasury } \\
\text { Bills }\end{array}$ & $\begin{array}{l}\text { Long } \\
\text { Canada } \\
\text { Bonds } \\
\end{array}$ & $\begin{array}{c}\text { Provincial } \\
\text { Bonds } \\
\end{array}$ & $\begin{array}{c}\text { Municipal } \\
\text { Bonds }\end{array}$ & $\begin{array}{c}\text { Industrial } \\
\text { Bonds }\end{array}$ & $\underline{\text { Equities }}$ & C.P.I. \\
\hline 1950 & 1.0051 & 0.9989 & 1.0000 & 1.0341 & 1.0267 & 1.2770 & 1.0610 \\
\hline 1951 & 1.0123 & 0.9688 & 0.9205 & 0.9267 & 0.9607 & 1.6178 & 1.1748 \\
\hline 1952 & 1.0219 & 0.9886 & 0.9659 & 0.9875 & 1.0033 & 1.6338 & 1.1545 \\
\hline 1953 & 1.0377 & 1.0258 & 1.0163 & 1.0466 & 1.0434 & 1.4889 & 1.1545 \\
\hline 1954 & 1.0546 & 1.1262 & 1.1527 & 1.1915 & 1.1512 & 2.1292 & 1.1585 \\
\hline 1955 & 1.0675 & 1.1213 & 1.1222 & 1.1932 & 1.1763 & 2.6312 & 1.1626 \\
\hline 1956 & 1.0955 & 1.0816 & 1.0128 & 1.0608 & 1.0869 & 2.8979 & 1.1992 \\
\hline 1957 & 1.1367 & 1.1530 & 1.1186 & 1.1624 & 1.1696 & 2.2865 & 1.2236 \\
\hline 1958 & 1.1625 & 1.0860 & 1.1023 & 1.1882 & 1.2047 & 2.9659 & 1.2561 \\
\hline 1959 & 1.2135 & 1.0378 & 1.0476 & 1.1082 & 1.1529 & 3.0442 & 1.2724 \\
\hline 1960 & 1.2579 & 1.1092 & 1.1605 & 1.2548 & 1.2907 & 3.1062 & 1.2886 \\
\hline 1961 & 1.2939 & 1.2174 & 1.2692 & 1.3930 & 1.4060 & 4.1725 & 1.2927 \\
\hline 1962 & 1.3432 & 1.2559 & 1.3288 & 1.4638 & 1.4754 & 3.8565 & 1.3130 \\
\hline 1963 & 1.3913 & 1.3136 & 1.3885 & 1.5337 & 1.5547 & 4.3942 & 1.3374 \\
\hline 1964 & 1.4431 & 1.4021 & 1.4865 & 1.6403 & 1.6282 & 5.4748 & 1.3618 \\
\hline 1965 & 1.4978 & 1.4168 & 1.4908 & 1.6536 & 1.6182 & 5.7737 & 1.4024 \\
\hline 1966 & 1.5710 & 1.4412 & 1.4709 & 1.6403 & 1.5940 & 5.5217 & 1.4512 \\
\hline 1967 & 1.6399 & 1.4085 & 1.4723 & 1.6220 & 1.5881 & 6.6574 & 1.5122 \\
\hline 1968 & 1.7418 & 1.3997 & 1.4957 & 1.6578 & 1.6266 & 8.2027 & 1.5732 \\
\hline 1969 & 1.8607 & 1.3666 & 1.4524 & 1.5845 & 1.6099 & 8.1451 & 1.6463 \\
\hline 1970 & 1.9889 & 1.6769 & 1.7259 & 1.8859 & 1.8354 & 7.9181 & 1.6707 \\
\hline 1971 & 2.0657 & 1.8747 & 1.9560 & 2.2165 & 2.1003 & 8.8293 & 1.7520 \\
\hline 1972 & 2.1367 & 1.9045 & 2.0895 & 2.3372 & 2.3008 & 11.4223 & 1.8415 \\
\hline 1973 & 2.2388 & 1.9419 & 2.1108 & 2.3955 & 2.3559 & 11.0002 & 2.0122 \\
\hline 1974 & 2.4108 & 1.9228 & 2.0597 & 2.2956 & 2.2180 & 7.8886 & 2.2602 \\
\hline 1975 & 2.5807 & 1.9755 & 2.2067 & 2.4580 & 2.4027 & 9.5774 & 2.4756 \\
\hline 1976 & 2.8156 & 2.3637 & 2.6776 & 3.0733 & 2.9632 & 10.7196 & 2.6220 \\
\hline 1977 & 3.0306 & 2.5099 & 2.9190 & 3.3339 & 3.2765 & 12.2808 & 2.8699 \\
\hline 1978 & 3.2699 & 2.5468 & 3.0291 & 3.5012 & 3.4453 & 15.9709 & 3.1098 \\
\hline 1979 & 3.6311 & 2.4762 & 2.9425 & 3.4238 & 3.3926 & 24.1641 & 3.4146 \\
\hline 1980 & 4.0727 & 2.5372 & 3.0298 & 3.4779 & 3.4921 & 30.5389 & 3.7967 \\
\hline 1981 & 4.8502 & 2.4859 & 2.9581 & 3.4954 & 3.4645 & 27.2986 & 4.2561 \\
\hline 1982 & 5.5897 & 3.6246 & 4.3182 & 5.0766 & 4.9666 & 28.3860 & 4.6504 \\
\hline 1983 & 6.1181 & 3.9760 & 4.7699 & 5.6286 & 5.6566 & 39.0746 & 4.8618 \\
\hline 1984 & 6.8042 & 4.6293 & 5.6335 & 6.6978 & 6.7235 & 39.4530 & 5.0447 \\
\hline 1985 & 7.4649 & 5.8377 & 7.1023 & 8.3264 & 8.3542 & 49.4892 & 5.2642 \\
\hline 1986 & 8.1619 & 6.8707 & 8.2777 & 9.7003 & 9.3225 & 55.9132 & 5.4837 \\
\hline 1987 & 8.8291 & 6.9111 & 8.4155 & 9.9242 & 9.8997 & 54.0962 & 5.7114 \\
\hline
\end{tabular}




\section{TABLE 5-4}

\section{INDEX OF REAL WEALTH FOR BASIC RETURN SERIES, 1949 = 1.00 1950 TO 1987}

\begin{tabular}{|c|c|c|c|c|c|c|}
\hline Year & $\begin{array}{c}\text { Treasury } \\
\text { Bills }\end{array}$ & $\begin{array}{l}\text { Long } \\
\text { Canada } \\
\text { Bonds }\end{array}$ & $\begin{array}{c}\begin{array}{c}\text { Provincial } \\
\text { Bonds }\end{array} \\
\end{array}$ & $\begin{array}{c}\text { Municipal } \\
\text { Bonds }\end{array}$ & $\begin{array}{c}\text { Industrial } \\
\text { Bonds }\end{array}$ & Equities \\
\hline 1950 & 0.9474 & 0.9415 & 0.9425 & 0.9747 & 0.9677 & 1.2036 \\
\hline 1951 & 0.8617 & 0.8247 & 0.7835 & 0.7888 & 0.8178 & 1.3771 \\
\hline 1952 & 0.8852 & 0.8564 & 0.8367 & 0.8554 & 0.8691 & 1.4153 \\
\hline 1953 & 0.8989 & 0.8886 & 0.8803 & 0.9066 & 0.9038 & 1.2897 \\
\hline 1954 & 0.9103 & 0.9721 & 0.9950 & 1.0285 & 0.9937 & 1.8379 \\
\hline 1955 & 0.9182 & 0.9645 & 0.9652 & 1.0263 & 1.0118 & 2.2633 \\
\hline 1956 & 0.9135 & 0.9020 & 0.8446 & 0.8846 & 0.9064 & 2.4166 \\
\hline 1957 & 0.9290 & 0.9423 & 0.9142 & 0.9500 & 0.9559 & 1.8688 \\
\hline 1958 & 0.9255 & 0.8646 & 0.8775 & 0.9459 & 0.9591 & 2.3613 \\
\hline 1959 & 0.9537 & 0.8157 & 0.8233 & 0.8710 & 0.9061 & 2.3927 \\
\hline 1960 & 0.9762 & 0.8608 & 0.9006 & 0.9737 & 1.0016 & 2.4106 \\
\hline 1961 & 1.0010 & 0.9418 & 0.9818 & 1.0776 & 1.0877 & 3.2280 \\
\hline 1962 & 1.0230 & 0.9565 & 1.0121 & 1.1148 & 1.1236 & 2.9374 \\
\hline 1963 & 1.0403 & 0.9822 & 1.0382 & 1.1468 & 1.1625 & 3.2859 \\
\hline 1964 & 1.0597 & 1.0296 & 1.0916 & 1.2045 & 1.1957 & 4.0207 \\
\hline 1965 & 1.0680 & 1.0102 & 1.0630 & 1.1791 & 1.1539 & 4.1173 \\
\hline 1966 & 1.0826 & 0.9931 & 1.0135 & 1.1303 & 1.0984 & 3.8052 \\
\hline 1967 & 1.0844 & 0.9314 & 0.9736 & 1.0726 & 1.0502 & 4.4029 \\
\hline 1968 & 1.1072 & 0.8897 & 0.9508 & 1.0538 & 1.0339 & 5.2147 \\
\hline 1969 & 1.1302 & 0.8301 & 0.8822 & 0.9624 & 0.9778 & 4.9480 \\
\hline 1970 & 1.1904 & 1.0037 & 1.0330 & 1.1288 & 1.0986 & 4.7399 \\
\hline 1971 & 1.1791 & 1.0700 & 1.1164 & 1.2651 & 1.1988 & 5.0401 \\
\hline 1972 & 1.1603 & 1.0342 & 1.1347 & 1.2692 & 1.2494 & 6.2036 \\
\hline 1973 & 1.1126 & 0.9651 & 1.0490 & 1.1905 & 1.1708 & 5.4675 \\
\hline 1974 & 1.0667 & 0.8508 & 0.9113 & 1.0157 & 0.9814 & 3.4908 \\
\hline 1975 & 1.0425 & 0.7980 & 0.8914 & 0.9929 & 0.9705 & 3.8692 \\
\hline 1976 & 1.0738 & 0.9015 & 1.0212 & 1.1721 & 1.1302 & 4.0890 \\
\hline 1977 & 1.0560 & 0.8746 & 1.0171 & 1.1617 & 1.1417 & 4.2798 \\
\hline 1978 & 1.0515 & 0.8190 & 0.9741 & 1.1259 & 1.1079 & 5.1365 \\
\hline 1979 & 1.0634 & 0.7252 & 0.8617 & 1.0027 & 0.9936 & 7.0777 \\
\hline 1980 & 1.0727 & 0.6683 & 0.7980 & 0.9160 & 0.9197 & 8.0448 \\
\hline 1981 & 1.1396 & 0.5841 & 0.6950 & 0.8213 & 0.8140 & 6.4151 \\
\hline 1982 & 1.2020 & 0.7794 & 0.9286 & 1.0916 & 1.0680 & 6.1051 \\
\hline 1983 & 1.2584 & 0.8178 & 0.9811 & 1.1577 & 1.1635 & 8.0386 \\
\hline 1984 & 1.3488 & 0.9177 & 1.1167 & 1.3277 & 1.3328 & 7.8222 \\
\hline 1985 & 1.4180 & 1.1089 & 1.3492 & 1.5817 & 1.5870 & 9.4029 \\
\hline 1986 & 1.4884 & 1.2529 & 1.5095 & 1.7689 & 1.7000 & 10.1982 \\
\hline 1987 & 1.5459 & 1.2101 & 1.4735 & 1.7376 & 1.7333 & 9.4736 \\
\hline
\end{tabular}


TABLE 5-5

TREASURY BILLS: TOTAL RETURNS

RATES OF RETURN FOR VARIOUS HOLDING PERIODS FROM 1950 TO 1987

\begin{tabular}{|c|c|c|c|c|c|c|c|c|c|}
\hline $\begin{array}{l}\text { TO THE } \\
\text { END OF }\end{array}$ & $\begin{array}{l}\text { FROM } \\
1950\end{array}$ & $\begin{array}{l}\text { IE BEGI } \\
1951\end{array}$ & $\begin{array}{l}\text { NING OF } \\
1952\end{array}$ & 1953 & 1954 & 1955 & 1956 & 1957 & 1958 \\
\hline 1950 & 0.51 & & & & & & & & \\
\hline $\begin{array}{l}1951 \\
1952\end{array}$ & 0.61 & 0.71 & & & & & & & \\
\hline $\begin{array}{l}1952 \\
1953\end{array}$ & $\begin{array}{l}0.73 \\
0.93\end{array}$ & 0.83 & 0.95 & & & & & & \\
\hline $\begin{array}{l}1953 \\
1954\end{array}$ & 0.93 & 1.07 & 1.25 & $\begin{array}{l}1.54 \\
1.58\end{array}$ & 1.62 & & & & \\
\hline $\begin{array}{l}1954 \\
1955\end{array}$ & 1.07 & 1.21 & 1.37 & 1.58 & & & & & \\
\hline $\begin{array}{l}1955 \\
1956\end{array}$ & 1.09 & 1.21 & 1.34 & 1.46 & 1.42 & 1.22 & & & \\
\hline 1956 & 1.31 & 1.45 & 1.59 & 1.75 & 1.82 & 1.92 & 2.63 & & \\
\hline 1957 & 1.61 & 1.77 & 1.95 & 2.15 & 2.30 & 2.53 & 3.19 & 3.76 & \\
\hline 1958 & 1.69 & 1.83 & 2.00 & 2.17 & 2.30 & 2.47 & 2.88 & 3.01 & 2.27 \\
\hline 1959 & 1.95 & 2.12 & 2.29 & 2.48 & 2.64 & 2.85 & 3.26 & 3.47 & 3.32 \\
\hline 1960 & 2.11 & 2.27 & 2.44 & 2.63 & 2.79 & 2.98 & 3.34 & 3.52 & 3.44 \\
\hline 1961 & 2.17 & 2.32 & 2.49 & 2.66 & 2.80 & 2.97 & 3.26 & 3.39 & 3.29 \\
\hline 1962 & 2.30 & 2.45 & 2.60 & 2.77 & 2.91 & 3.07 & 3.34 & 3.46 & 3.39 \\
\hline 1963 & 2.39 & 2.53 & 2.69 & 2.84 & 2.98 & 3.13 & 3.37 & 3.47 & 3.43 \\
\hline 1964 & 2.48 & 2.62 & 2.77 & 2.92 & 3.04 & 3.19 & 3.41 & 3.51 & 3.47 \\
\hline 1965 & 2.56 & 2.70 & 2.84 & 2.98 & 3.11 & 3.24 & 3.45 & 3.54 & 3.51 \\
\hline 1966 & 2.69 & 2.83 & 2.97 & 3.12 & 3.24 & 3.38 & 3.58 & 3.67 & 3.66 \\
\hline 1967 & 2.79 & 2.92 & 3.06 & 3.20 & 3.32 & 3.45 & 3.64 & 3.74 & 3.73 \\
\hline 1968 & 2.96 & 3.10 & 3.24 & 3.39 & 3.51 & 3.65 & 3.84 & 3.94 & 3.96 \\
\hline 1969 & 3.15 & 3.29 & 3.44 & 3.59 & 3.72 & 3.86 & 4.05 & 4.16 & 4.19 \\
\hline 1970 & 3.33 & 3.47 & 3.62 & 3.77 & 3.90 & 4.05 & 4.24 & 4.35 & 4.40 \\
\hline 1971 & 3.35 & 3.49 & 3.63 & 3.77 & 3.90 & 4.03 & 4.21 & 4.32 & 4.36 \\
\hline 1972 & 3.36 & 3.49 & 3.62 & 3.76 & 3.87 & 4.00 & 4.17 & 4.26 & 4.30 \\
\hline 1973 & 3.42 & 3.54 & 3.67 & 3.81 & 3.92 & 4.04 & 4.20 & 4.29 & 4.33 \\
\hline 1974 & 3.58 & 3.71 & 3.84 & 3.98 & 4.10 & 4.22 & 4.38 & 4.48 & 4.52 \\
\hline 1975 & 3.71 & 3.84 & 3.98 & 4.11 & 4.23 & 4.35 & 4.51 & 4.61 & 4.66 \\
\hline 1976 & 3.91 & 4.04 & 4.18 & 4.31 & 4.44 & 4.56 & 4.73 & 4.83 & 4.89 \\
\hline 1977 & 4.04 & 4.17 & 4.31 & 4.44 & 4.57 & 4.70 & 4.86 & 4.96 & 5.03 \\
\hline 1978 & 4.17 & 4.30 & 4.44 & 4.57 & 4.70 & 4.83 & 4.99 & 5.10 & 5.16 \\
\hline 1979 & 4.39 & 4.53 & 4.67 & 4.81 & 4.94 & 5.07 & 5.23 & 5.35 & 5.42 \\
\hline 1980 & 4.63 & 4.77 & 4.92 & 5.06 & 5.19 & 5.33 & 5.50 & 5.62 & 5.71 \\
\hline 1981 & 5.06 & 5.21 & 5.36 & 5.52 & 5.66 & 5.81 & 5.99 & 6.13 & 6.23 \\
\hline 1982 & 5.35 & 5.51 & 5.67 & 5.83 & 5.98 & 6.14 & 6.32 & 6.47 & 6.58 \\
\hline 1983 & 5.47 & 5.63 & 5.78 & 5.94 & 6.09 & 6.25 & 6.43 & 6.58 & 6.69 \\
\hline 1984 & 5.63 & 5.79 & 5.94 & 6.10 & 6.25 & 6.41 & 6.60 & 6.74 & 6.85 \\
\hline 1985 & 5.74 & 5.90 & 6.05 & 6.21 & 6.36 & 6.52 & 6.70 & 6.84 & 6.95 \\
\hline 1986 & 5.84 & 5.99 & 6.15 & 6.30 & 6.45 & 6.60 & 6.78 & 6.92 & 7.03 \\
\hline 1987 & 5.90 & 6.05 & 6.20 & 6.35 & 6.50 & 6.65 & 6.83 & 6.96 & 7.07 \\
\hline
\end{tabular}


TABLE 5-5 (Continued)

\begin{tabular}{lllllllllll} 
TO THE & \multicolumn{2}{l}{ FROM THE BEGINNING OF } & & & & & \\
END OF & $\mathbf{1 9 5 9}$ & $\mathbf{1 9 6 0}$ & $\mathbf{1 9 6 1}$ & $\mathbf{1 9 6 2}$ & $\mathbf{1 9 6 3}$ & $\mathbf{1 9 6 4}$ & $\mathbf{1 9 6 5}$ & $\mathbf{1 9 6 6}$ & $\mathbf{1 9 6 7}$ & $\mathbf{1 9 6 8}$ \\
& & & & & & & & & & \\
1959 & 4.39 & & & & & & & & & \\
1960 & 4.02 & 3.66 & & & & & & & & \\
1961 & 3.64 & 3.26 & 2.86 & & & & & & & \\
1962 & 3.68 & 3.44 & 3.33 & 3.81 & & & & & & \\
1963 & 3.66 & 3.48 & 3.42 & 3.69 & 3.58 & & & & & \\
1964 & 3.67 & 3.53 & 3.49 & 3.70 & 3.65 & 3.73 & & & & \\
1965 & 3.69 & 3.57 & 3.55 & 3.73 & 3.70 & 3.76 & 3.79 & & & \\
1966 & 3.84 & 3.76 & 3.77 & 3.96 & 4.00 & 4.13 & 4.34 & 4.89 & & \\
1967 & 3.90 & 3.84 & 3.86 & 4.03 & 4.07 & 4.20 & 4.35 & 4.64 & 4.38 & \\
1968 & 4.13 & 4.10 & 4.15 & 4.34 & 4.43 & 4.60 & 4.82 & 5.16 & 5.30 & 6.22 \\
1969 & 4.37 & 4.37 & 4.45 & 4.65 & 4.77 & 4.97 & 5.21 & 5.57 & 5.80 & 6.52 \\
1970 & 4.58 & 4.59 & 4.69 & 4.89 & 5.03 & 5.24 & 5.49 & 5.84 & 6.07 & 6.64 \\
1971 & 4.52 & 4.53 & 4.61 & 4.79 & 4.90 & 5.06 & 5.26 & 5.50 & 5.63 & 5.94 \\
1972 & 4.44 & 4.45 & 4.51 & 4.67 & 4.75 & 4.88 & 5.03 & 5.21 & 5.26 & 5.44 \\
1973 & 4.47 & 4.47 & 4.53 & 4.67 & 4.75 & 4.87 & 5.00 & 5.15 & 5.19 & 5.33 \\
1974 & 4.66 & 4.68 & 4.76 & 4.90 & 5.00 & 5.12 & 5.27 & 5.43 & 5.50 & 5.66 \\
1975 & 4.80 & 4.83 & 4.91 & 5.05 & 5.15 & 5.28 & 5.43 & 5.59 & 5.67 & 5.83 \\
1976 & 5.04 & 5.08 & 5.16 & 5.32 & 5.43 & 5.57 & 5.73 & 5.91 & 6.01 & 6.19 \\
1977 & 5.17 & 5.22 & 5.31 & 5.46 & 5.57 & 5.72 & 5.87 & 6.05 & 6.15 & 6.33 \\
1978 & 5.31 & 5.36 & 5.45 & 5.60 & 5.72 & 5.86 & 6.02 & 6.19 & 6.30 & 6.47 \\
1979 & 5.57 & 5.63 & 5.74 & 5.90 & 6.02 & 6.18 & 6.34 & 6.53 & 6.66 & 6.85 \\
1980 & 5.86 & 5.94 & 6.05 & 6.22 & 6.36 & 6.52 & 6.70 & 6.90 & 7.04 & 7.25 \\
1981 & 6.41 & 6.50 & 6.64 & 6.83 & 6.99 & 7.18 & 7.39 & 7.62 & 7.80 & 8.05 \\
1982 & 6.76 & 6.87 & 7.01 & 7.22 & 7.39 & 7.59 & 7.81 & 8.05 & 8.26 & 8.52 \\
1983 & 6.87 & 6.97 & 7.12 & 7.32 & 7.49 & 7.69 & 7.90 & 8.13 & 8.33 & 8.58 \\
1984 & 7.03 & 7.14 & 7.29 & 7.48 & 7.65 & 7.85 & 8.06 & 8.29 & 8.48 & 8.73 \\
1985 & 7.13 & 7.24 & 7.38 & 7.58 & 7.74 & 7.94 & 8.14 & 8.36 & 8.55 & 8.78 \\
1986 & 7.21 & 7.31 & 7.46 & 7.65 & 7.81 & 8.00 & 8.19 & 8.41 & 8.59 & 8.81 \\
1987 & 7.24 & 7.34 & 7.48 & 7.67 & 7.82 & 8.00 & 8.19 & 8.40 & 8.57 & 8.78
\end{tabular}




\section{TABLE 5-5 (Continued)}

\begin{tabular}{|c|c|c|c|c|c|c|c|c|c|}
\hline $\begin{array}{l}\text { TO THE } \\
\text { END OF }\end{array}$ & $\begin{array}{l}\text { FROM } \\
1969\end{array}$ & $\begin{array}{c}\text { HE BEC } \\
1970\end{array}$ & $\underset{1971}{\text { NING OF }}$ & 1972 & 1973 & 1974 & 1975 & 1976 & 1977 \\
\hline 1969 & 6.83 & & & & & & & & \\
\hline 1970 & 6.86 & 6.89 & & & & & & & \\
\hline 1971 & 5.85 & 5.37 & 3.86 & & & & & & \\
\hline 1972 & 5.24 & 4.72 & 3.65 & 3.44 & & & & & \\
\hline 1973 & 5.15 & 4.73 & 4.02 & 4.10 & 4.78 & & & & \\
\hline 1974 & 5.57 & 5.32 & 4.93 & 5.28 & 6.22 & 7.68 & & & \\
\hline 1975 & 5.78 & 5.60 & 5.35 & 5.72 & 6.50 & 7.36 & 7.05 & & \\
\hline 1976 & 6.19 & 6.10 & 5.96 & 6.39 & 7.14 & 7.94 & 8.07 & 9.10 & \\
\hline 1977 & 6.35 & 6.29 & 6.20 & 6.60 & 7.24 & 7.86 & 7.92 & 8.37 & 7.64 \\
\hline 1978 & 6.50 & 6.46 & 6.41 & 6.78 & 7.35 & 7.87 & 7.92 & 8.21 & 7.77 \\
\hline 1979 & 6.91 & 6.91 & 6.92 & 7.30 & 7.87 & 8.39 & 8.54 & 8.91 & 8.85 \\
\hline 1980 & 7.33 & 7.38 & 7.43 & 7.83 & 8.40 & 8.92 & 9.13 & 9.55 & 9.67 \\
\hline 1981 & 8.20 & 8.31 & 8.44 & 8.91 & 9.54 & 10.15 & 10.50 & 11.09 & 11.49 \\
\hline 1982 & 8.69 & 8.83 & 8.99 & 9.47 & 10.09 & 10.70 & 11.08 & 11.67 & 12.11 \\
\hline 1983 & 8.74 & 8.87 & 9.03 & 9.47 & 10.04 & 10.58 & 10.90 & 11.39 & 11.72 \\
\hline 1984 & 8.89 & 9.03 & 9.18 & 9.60 & 10.13 & 10.63 & 10.93 & 11.37 & 11.66 \\
\hline 1985 & 8.94 & 9.07 & 9.22 & 9.61 & 10.10 & 10.56 & 10.82 & 11.21 & 11.44 \\
\hline 1986 & 8.96 & 9.09 & 9.23 & 9.59 & 10.05 & 10.46 & 10.70 & 11.03 & 11.23 \\
\hline 1987 & 8.92 & 9.04 & 9.16 & 9.50 & 9.92 & 10.30 & 10.50 & 10.79 & 10.95 \\
\hline
\end{tabular}

TO THE FROM THE BEGINNING OF

$\begin{array}{lrrrrrrrrrr}\text { END OF } & \mathbf{1 9 7 8} & \mathbf{1 9 7 9} & \mathbf{1 9 8 0} & \mathbf{1 9 8 1} & \mathbf{1 9 8 2} & \mathbf{1 9 8 3} & \mathbf{1 9 8 4} & \mathbf{1 9 8 5} & \mathbf{1 9 8 6} & \mathbf{1 9 8 7} \\ 1978 & 7.90 & & & & & & & & & \\ 1979 & 9.46 & 11.05 & & & & & & & & \\ 1980 & 10.35 & 11.60 & 12.16 & & & & & & & \\ 1981 & 12.48 & 14.04 & 15.58 & 19.09 & & & & & & \\ 1982 & 13.02 & 14.34 & 15.47 & 17.15 & 15.25 & & & & \\ 1983 & 12.42 & 13.35 & 13.93 & 14.53 & 12.31 & 9.45 & & & & \\ 1984 & 12.25 & 12.99 & 13.38 & 13.69 & 11.94 & 10.33 & 11.21 & & & \\ 1985 & 11.93 & 12.52 & 12.76 & 12.88 & 11.38 & 10.12 & 10.46 & 9.71 & & \\ 1986 & 11.64 & 12.11 & 12.27 & 12.28 & 10.97 & 9.93 & 10.08 & 9.52 & 9.34 & \\ 1987 & 11.29 & 11.67 & 11.75 & 11.69 & 10.50 & 9.57 & 9.60 & 9.07 & 8.75 & 8.17\end{array}$


TABLE 5-6

TREASURY BILLS: REAL RETURNS

RATES OF RETURN FOR VARIOUS HOLDING PERIODS FROM 1950 TO 1987

\begin{tabular}{|c|c|c|c|c|c|c|c|c|c|}
\hline $\begin{array}{l}\text { TO THE } \\
\text { END OF }\end{array}$ & $\begin{array}{l}\text { FROM } \\
1950\end{array}$ & $\begin{array}{c}\text { HE BEG } \\
1951\end{array}$ & $\begin{array}{l}\text { NING OF } \\
1952\end{array}$ & 1953 & 1954 & 1955 & 1956 & 1957 & 1958 \\
\hline 1950 & -5.26 & & & & & & & & \\
\hline 1951 & -7.17 & -9.04 & & & & & & & \\
\hline 1952 & -3.98 & -3.34 & 2.73 & & & & & & \\
\hline 1953 & -2.63 & -1.74 & 2.14 & 1.54 & & & & & \\
\hline 1954 & -1.86 & -0.99 & 1.85 & 1.40 & 1.26 & & & & \\
\hline 1955 & -1.41 & -0.62 & 1.60 & 1.23 & 1.07 & 0.87 & & & \\
\hline 1956 & -1.28 & -0.60 & 1.18 & 0.79 & 0.54 & 0.18 & -0.50 & & \\
\hline 1957 & -0.92 & -0.28 & 1.26 & 0.97 & 0.83 & 0.68 & 0.59 & 1.69 & \\
\hline 1958 & -0.86 & -0.29 & 1.03 & 0.74 & 0.58 & 0.42 & 0.26 & 0.65 & -0.38 \\
\hline 1959 & -0.47 & 0.07 & 1.28 & 1.07 & 0.99 & 0.94 & 0.95 & 1.45 & 1.32 \\
\hline 1960 & -0.22 & 0.30 & 1.40 & 1.23 & 1.19 & 1.17 & 1.23 & 1.67 & 1.67 \\
\hline 1961 & 0.01 & 0.50 & 1.51 & 1.37 & 1.35 & 1.37 & 1.45 & 1.84 & 1.88 \\
\hline 1962 & 0.17 & 0.64 & 1.57 & 1.46 & 1.45 & 1.47 & 1.56 & 1.90 & 1.95 \\
\hline 1963 & 0.28 & 0.72 & 1.58 & 1.48 & 1.47 & 1.49 & 1.57 & 1.87 & 1.90 \\
\hline 1964 & 0.39 & 0.80 & 1.60 & 1.51 & 1.51 & 1.53 & 1.61 & 1.87 & 1.90 \\
\hline 1965 & 0.41 & 0.80 & 1.55 & 1.45 & 1.45 & 1.46 & 1.52 & 1.75 & 1.76 \\
\hline 1966 & 0.47 & 0.84 & 1.53 & 1.45 & 1.44 & 1.46 & 1.51 & 1.71 & 1.71 \\
\hline 1967 & 0.45 & 0.80 & 1.45 & 1.36 & 1.35 & 1.36 & 1.40 & 1.57 & 1.56 \\
\hline 1968 & 0.54 & 0.87 & 1.49 & 1.41 & 1.40 & 1.41 & 1.45 & 1.62 & 1.61 \\
\hline 1969 & 0.61 & 0.93 & 1.52 & 1.45 & 1.44 & 1.45 & 1.50 & 1.65 & 1.65 \\
\hline 1970 & 0.83 & 1.15 & 1.72 & 1.66 & 1.67 & 1.69 & 1.75 & 1.91 & 1.93 \\
\hline 1971 & 0.75 & 1.05 & 1.58 & 1.52 & 1.52 & 1.53 & 1.58 & 1.72 & 1.72 \\
\hline 1972 & 0.65 & 0.93 & 1.43 & 1.36 & 1.35 & 1.36 & 1.39 & 1.51 & 1.49 \\
\hline 1973 & 0.45 & 0.70 & 1.17 & 1.09 & 1.07 & 1.06 & 1.07 & 1.17 & 1.13 \\
\hline 1974 & 0.26 & 0.50 & 0.93 & 0.85 & 0.82 & 0.80 & 0.79 & 0.86 & 0.82 \\
\hline 1975 & 0.16 & 0.38 & 0.80 & 0.71 & 0.68 & 0.65 & 0.64 & 0.70 & 0.64 \\
\hline 1976 & 0.26 & 0.48 & 0.88 & 0.81 & 0.78 & 0.75 & 0.75 & 0.81 & 0.77 \\
\hline 1977 & 0.19 & 0.40 & 0.79 & 0.71 & 0.67 & 0.65 & 0.64 & 0.69 & 0.64 \\
\hline 1978 & 0.17 & 0.37 & 0.74 & 0.66 & 0.63 & 0.60 & 0.59 & 0.64 & 0.59 \\
\hline 1979 & 0.21 & 0.40 & 0.75 & 0.68 & 0.65 & 0.62 & 0.61 & 0.66 & 0.62 \\
\hline 1980 & 0.23 & 0.42 & 0.76 & 0.69 & 0.66 & 0.63 & 0.62 & 0.67 & 0.63 \\
\hline 1981 & 0.41 & 0.60 & 0.94 & 0.87 & 0.85 & 0.84 & 0.83 & 0.89 & 0.86 \\
\hline 1982 & 0.56 & 0.75 & 1.08 & 1.02 & 1.01 & 1.00 & 1.00 & 1.06 & 1.04 \\
\hline 1983 & 0.68 & 0.86 & 1.19 & 1.14 & 1.13 & 1.12 & 1.13 & 1.19 & 1.17 \\
\hline 1984 & 0.86 & 1.04 & 1.37 & 1.32 & 1.32 & 1.32 & 1.33 & 1.40 & 1.39 \\
\hline 1985 & 0.97 & 1.16 & 1.48 & 1.44 & 1.43 & 1.44 & 1.46 & 1.53 & 1.52 \\
\hline 1986 & 1.08 & 1.26 & 1.57 & 1.54 & 1.54 & 1.55 & 1.57 & 1.64 & 1.64 \\
\hline 1987 & 1.15 & 1.33 & 1.64 & 1.61 & 1.61 & 1.62 & 1.64 & 1.71 & 1.71 \\
\hline
\end{tabular}


TABLE 5-6 (Continued)

\begin{tabular}{|c|c|c|c|c|c|c|c|c|c|c|}
\hline TO THE & FROM & THE BI & INN & & & & & & & \\
\hline END OF & 1959 & 1960 & 1961 & 1962 & 1963 & 1964 & 1965 & 1966 & 1967 & 1968 \\
\hline 1959 & 3.05 & & & & & & & & & \\
\hline 1960 & 2.70 & 2.35 & & & & & & & & \\
\hline 1961 & 2.65 & 2.45 & 2.54 & & & & & & & \\
\hline 1962 & 2.54 & 2.36 & 2.37 & 2.20 & & & & & & \\
\hline 1963 & 2.37 & 2.20 & 2.14 & 1.95 & 1.69 & & & & & \\
\hline 1964 & 2.28 & 2.13 & 2.07 & 1.92 & 1.78 & 1.87 & & & & \\
\hline 1965 & 2.07 & 1.90 & 1.81 & 1.63 & 1.45 & 1.32 & 0.78 & & & \\
\hline 1966 & 1.98 & 1.83 & 1.74 & 1.58 & 1.43 & 1.34 & 1.07 & 1.36 & & \\
\hline 1967 & 1.78 & 1.62 & 1.51 & 1.34 & 1.17 & 1.04 & 0.77 & 0.77 & 0.17 & \\
\hline 1968 & 1.81 & 1.67 & 1.59 & 1.45 & 1.33 & 1.25 & 1.10 & 1.21 & 1.13 & 2.10 \\
\hline 1969 & 1.83 & 1.71 & 1.64 & 1.53 & 1.43 & 1.39 & 1.30 & 1.43 & 1.45 & 2.09 \\
\hline 1970 & 2.12 & 2.04 & 2.00 & 1.94 & 1.91 & 1.94 & 1.96 & 2.19 & 2.40 & 3.16 \\
\hline 1971 & 1.88 & 1.78 & 1.73 & 1.65 & 1.59 & 1.58 & 1.54 & 1.66 & 1.72 & 2.11 \\
\hline 1972 & 1.63 & 1.52 & 1.45 & 1.35 & 1.27 & 1.22 & 1.14 & 1.19 & 1.16 & 1.36 \\
\hline 1973 & 1.24 & 1.11 & 1.01 & 0.89 & 0.77 & 0.67 & 0.54 & 0.51 & 0.39 & 0.43 \\
\hline 1974 & 0.89 & 0.75 & 0.64 & 0.49 & 0.35 & 0.23 & 0.07 & -0.01 & -0.18 & -0.24 \\
\hline 1975 & 0.70 & 0.56 & 0.44 & 0.29 & 0.15 & 0.02 & -0.15 & -0.24 & -0.42 & -0.49 \\
\hline 1976 & 0.83 & 0.70 & 0.60 & 0.47 & 0.35 & 0.24 & 0.11 & 0.05 & -0.08 & -0.11 \\
\hline 1977 & 0.70 & 0.57 & 0.46 & 0.33 & 0.21 & 0.11 & -0.03 & -0.09 & -0.23 & -0.27 \\
\hline 1978 & 0.64 & 0.51 & 0.41 & 0.29 & 0.17 & 0.07 & -0.06 & -0.12 & -0.24 & -0.28 \\
\hline 1979 & 0.66 & 0.55 & 0.45 & 0.34 & 0.23 & 0.14 & 0.02 & -0.03 & -0.14 & -0.16 \\
\hline 1980 & 0.67 & 0.56 & 0.47 & 0.36 & 0.26 & 0.18 & 0.08 & 0.03 & -0.07 & -0.08 \\
\hline 1981 & 0.91 & 0.81 & 0.74 & 0.65 & 0.57 & 0.51 & 0.43 & 0.41 & 0.34 & 0.36 \\
\hline 1982 & 1.10 & 1.01 & 0.95 & 0.88 & 0.81 & 0.76 & 0.70 & 0.70 & 0.66 & 0.69 \\
\hline 1983 & 1.24 & 1.16 & 1.11 & 1.05 & 0.99 & 0.96 & 0.91 & 0.92 & 0.89 & 0.93 \\
\hline 1984 & 1.46 & 1.40 & 1.36 & 1.31 & 1.26 & 1.24 & 1.21 & 1.24 & 1.23 & 1.29 \\
\hline 1985 & 1.59 & 1.54 & 1.50 & 1.46 & 1.43 & 1.42 & 1.40 & 1.43 & 1.43 & 1.50 \\
\hline 1986 & 1.71 & 1.66 & 1.64 & 1.60 & 1.57 & 1.57 & 1.56 & 1.59 & 1.60 & 1.68 \\
\hline 1987 & 1.78 & 1.74 & 1.72 & 1.69 & 1.67 & 1.66 & 1.66 & 1.70 & 1.71 & 1.79 \\
\hline
\end{tabular}


TABLE 5-6 (Continued)

\begin{tabular}{llllllllll} 
TO THE & \multicolumn{2}{l}{ FROM THE BEGINNING OF } & & & & & \\
END OF & $\mathbf{1 9 6 9}$ & $\mathbf{1 9 7 0}$ & $\mathbf{1 9 7 1}$ & $\mathbf{1 9 7 2}$ & $\mathbf{1 9 7 3}$ & $\mathbf{1 9 7 4}$ & $\mathbf{1 9 7 5}$ & $\mathbf{1 9 7 6}$ & $\mathbf{1 9 7 7}$ \\
1969 & 2.08 & & & & & & & & \\
1970 & 3.69 & 5.33 & & & & & & & \\
1971 & 2.12 & 2.14 & -0.96 & & & & & & \\
1972 & 1.18 & 0.88 & -1.27 & -1.59 & & & & & \\
1973 & 0.10 & -0.39 & -2.23 & -2.86 & -4.11 & & & & \\
1974 & -0.62 & -1.15 & -2.71 & -3.28 & -4.12 & -4.13 & & & \\
1975 & -0.86 & -1.34 & -2.62 & -3.03 & -3.51 & -3.20 & -2.27 & & \\
1976 & -0.38 & -0.73 & -1.70 & -1.85 & -1.92 & -1.18 & 0.34 & 3.01 & \\
1977 & -0.52 & -0.85 & -1.70 & -1.82 & -1.87 & -1.30 & -0.33 & 0.65 & -1.66 \\
1978 & -0.51 & -0.80 & -1.54 & -1.62 & -1.63 & -1.12 & -0.36 & 0.29 & -1.05 \\
1979 & -0.37 & -0.61 & -1.25 & -1.28 & -1.24 & -0.75 & -0.06 & 0.50 & -0.33 \\
1980 & -0.26 & -0.47 & -1.04 & -1.05 & -0.98 & -0.52 & 0.09 & 0.57 & -0.03 \\
1981 & 0.22 & 0.07 & -0.40 & -0.34 & -0.20 & 0.30 & 0.95 & 1.50 & 1.20 \\
1982 & 0.59 & 0.47 & 0.08 & 0.18 & 0.35 & 0.86 & 1.50 & 2.06 & 1.90 \\
1983 & 0.86 & 0.77 & 0.43 & 0.54 & 0.74 & 1.24 & 1.85 & 2.38 & 2.29 \\
1984 & 1.24 & 1.19 & 0.90 & 1.04 & 1.26 & 1.77 & 2.37 & 2.90 & 2.89 \\
1985 & 1.47 & 1.43 & 1.17 & 1.33 & 1.55 & 2.04 & 2.62 & 3.12 & 3.14 \\
1986 & 1.66 & 1.63 & 1.41 & 1.57 & 1.79 & 2.26 & 2.82 & 3.29 & 3.32 \\
1987 & 1.77 & 1.76 & 1.55 & 1.71 & 1.93 & 2.38 & 2.90 & 3.34 & 3.37
\end{tabular}

\begin{tabular}{lcccccccccc} 
TO THE & \multicolumn{2}{c}{ FROM THE BEGINNING OF } & & & & & \\
END OF & $\mathbf{1 9 7 8}$ & $\mathbf{1 9 7 9}$ & $\mathbf{1 9 8 0}$ & $\mathbf{1 9 8 1}$ & $\mathbf{1 9 8 2}$ & $\mathbf{1 9 8 3}$ & $\mathbf{1 9 8 4}$ & $\mathbf{1 9 8 5}$ & $\mathbf{1 9 8 6}$ & $\mathbf{1 9 8 7}$ \\
1978 & -0.42 & & & & & & & & & \\
1979 & 0.35 & 1.13 & & & & & & & & \\
1980 & 0.52 & 1.00 & 0.87 & & & & & & & \\
1981 & 1.92 & 2.72 & 3.52 & 6.24 & & & & & & \\
1982 & 2.62 & 3.40 & 4.17 & 5.86 & 5.47 & & & & & \\
1983 & 2.97 & 3.66 & 4.30 & 5.47 & 5.08 & 4.69 & & & & \\
1984 & 3.56 & 4.24 & 4.87 & 5.89 & 5.78 & 5.93 & 7.18 & & & \\
1985 & 3.75 & 4.36 & 4.91 & 5.74 & 5.62 & 5.66 & 6.15 & 5.14 & & \\
1986 & 3.89 & 4.44 & 4.92 & 5.61 & 5.49 & 5.49 & 5.75 & 5.05 & 4.96 & \\
1987 & 3.88 & 4.38 & 4.79 & 5.36 & 5.21 & 5.16 & 5.28 & 4.65 & 4.41 & 3.86
\end{tabular}


TABLE 5-7

LONG CANADA BONDS: TOTAL RETURNS RATES OF RETURN FOR VARIOUS HOLDING PERIODS FROM 1950 TO 1987

\begin{tabular}{|c|c|c|c|c|c|c|c|c|c|}
\hline $\begin{array}{l}\text { TO THE } \\
\text { END OF }\end{array}$ & $\begin{array}{l}\text { FROM } \\
1950\end{array}$ & $\underset{1951}{\text { HE BEGI }}$ & $\begin{array}{l}\text { NING OF } \\
1952\end{array}$ & 1953 & 1954 & 1955 & 1956 & 1957 & 1958 \\
\hline $\begin{array}{l}1950 \\
1951\end{array}$ & $\begin{array}{l}-0.11 \\
-1.57\end{array}$ & & & & & & & & \\
\hline $\begin{array}{l}1951 \\
1952\end{array}$ & $\begin{array}{l}-1.57 \\
-0.38\end{array}$ & $\begin{array}{l}-3.01 \\
-0.51\end{array}$ & 2.05 & & & & & & \\
\hline 1953 & 0.64 & 0.89 & 2.90 & 3.76 & & & & & \\
\hline 1954 & 2.41 & 3.04 & 5.14 & 6.73 & 9.78 & & & & \\
\hline 1955 & 1.93 & 2.34 & 3.72 & 4.29 & 4.55 & -0.43 & & & \\
\hline 1956 & 1.13 & 1.33 & 2.23 & 2.27 & 1.78 & -2.00 & -3.54 & & \\
\hline 1957 & 1.80 & 2.07 & 2.94 & 3.12 & 2.96 & 0.79 & 1.40 & 6.60 & \\
\hline 1958 & 0.92 & 1.05 & 1.64 & 1.58 & 1.15 & -0.90 & -1.06 & 0.20 & -5.82 \\
\hline 1959 & 0.37 & 0.43 & 0.86 & 0.70 & 0.19 & -1.62 & -1.92 & -1.37 & -5.13 \\
\hline 1960 & 0.95 & 1.05 & 1.52 & 1.45 & 1.12 & -0.25 & -0.22 & 0.63 & -1.28 \\
\hline 1961 & 1.65 & 1.81 & 2.31 & 2.34 & 2.16 & 1.12 & 1.38 & 2.39 & 1.37 \\
\hline 1962 & 1.77 & 1.93 & 2.39 & 2.42 & 2.27 & 1.37 & 1.63 & 2.52 & 1.72 \\
\hline 1963 & 1.97 & 2.13 & 2.57 & 2.62 & 2.50 & 1.72 & 2.00 & 2.81 & 2.20 \\
\hline 1964 & 2.28 & 2.45 & 2.88 & 2.95 & 2.88 & 2.22 & 2.51 & 3.30 & 2.83 \\
\hline 1965 & 2.20 & 2.36 & 2.75 & 2.81 & 2.73 & 2.11 & 2.37 & 3.04 & 2.61 \\
\hline 1966 & 2.17 & 2.32 & 2.68 & 2.73 & 2.65 & 2.08 & 2.31 & 2.91 & 2.51 \\
\hline 1967 & 1.92 & 2.04 & 2.37 & 2.39 & 2.29 & 1.74 & 1.92 & 2.43 & 2.02 \\
\hline 1968 & 1.79 & 1.89 & 2.19 & 2.20 & 2.09 & 1.57 & 1.72 & 2.17 & 1.78 \\
\hline 1969 & 1.57 & 1.66 & 1.93 & 1.92 & 1.81 & 1.30 & 1.42 & 1.82 & 1.43 \\
\hline 1970 & 2.49 & 2.62 & 2.93 & 2.98 & 2.93 & 2.52 & 2.72 & 3.18 & 2.92 \\
\hline 1971 & 2.90 & 3.04 & 3.36 & 3.43 & 3.41 & 3.04 & 3.26 & 3.73 & 3.53 \\
\hline 1972 & 2.84 & 2.98 & 3.27 & 3.33 & 3.31 & 2.96 & 3.16 & 3.60 & 3.40 \\
\hline 1973 & 2.80 & 2.93 & 3.21 & 3.27 & 3.24 & 2.91 & 3.10 & 3.50 & 3.31 \\
\hline 1974 & 2.65 & 2.77 & 3.03 & 3.07 & 3.04 & 2.71 & 2.88 & 3.25 & 3.05 \\
\hline 1975 & 2.65 & 2.77 & 3.01 & 3.06 & 3.02 & 2.71 & 2.87 & 3.22 & 3.04 \\
\hline 1976 & 3.24 & 3.37 & 3.63 & 3.70 & 3.70 & 3.43 & 3.61 & 3.99 & 3.85 \\
\hline 1977 & 3.34 & 3.47 & 3.73 & 3.80 & 3.80 & 3.55 & 3.73 & 4.09 & 3.97 \\
\hline 1978 & 3.28 & 3.40 & 3.64 & 3.71 & 3.70 & 3.46 & 3.63 & 3.97 & 3.85 \\
\hline 1979 & 3.07 & 3.18 & 3.41 & 3.46 & 3.45 & 3.20 & 3.36 & 3.67 & 3.54 \\
\hline 1980 & 3.05 & 3.16 & 3.38 & 3.42 & 3.41 & 3.17 & 3.32 & 3.62 & 3.49 \\
\hline 1981 & 2.89 & 2.98 & 3.19 & 3.23 & 3.21 & 2.98 & 3.11 & 3.38 & 3.25 \\
\hline 1982 & 3.98 & 4.11 & 4.35 & 4.43 & 4.45 & 4.26 & 4.44 & 4.76 & 4.69 \\
\hline 1983 & 4.14 & 4.27 & 4.51 & 4.59 & 4.62 & 4.45 & 4.62 & 4.94 & 4.88 \\
\hline 1984 & 4.48 & 4.61 & 4.85 & 4.94 & 4.98 & 4.82 & 5.01 & 5.33 & 5.28 \\
\hline 1985 & 5.02 & 5.17 & 5.42 & 5.53 & 5.58 & 5.45 & 5.65 & 5.99 & 5.96 \\
\hline 1986 & 5.35 & 5.50 & 5.76 & 5.87 & 5.93 & 5.81 & 6.02 & 6.36 & 6.35 \\
\hline 1987 & 5.22 & 5.37 & 5.61 & 5.71 & 5.77 & 5.65 & 5.85 & 6.17 & 6.15 \\
\hline
\end{tabular}


TABLE 5-7 (Continued)

\begin{tabular}{|c|c|c|c|c|c|c|c|c|c|c|}
\hline TO THE & FROM & THE BI & INNIN & OF & & & & & & \\
\hline END OF & & 1960 & & 1962 & 1963 & 1964 & 1965 & 1966 & 1967 & 1968 \\
\hline 1959 & -4.44 & & & & & & & & & \\
\hline 1960 & 1.06 & 6.88 & & & & & & & & \\
\hline 1961 & 3.88 & 8.31 & 9.75 & & & & & & & \\
\hline 1962 & 3.70 & 6.56 & 6.41 & 3.16 & & & & & & \\
\hline 1963 & 3.88 & 6.07 & 5.80 & 3.87 & 4.59 & & & & & \\
\hline 1964 & 4.35 & 6.20 & 6.03 & 4.82 & 5.66 & 6.74 & & & & \\
\hline 1965 & 3.87 & 5.32 & 5.02 & 3.86 & 4.10 & 3.85 & 1.04 & & & \\
\hline 1966 & 3.60 & 4.80 & 4.46 & 3.43 & 3.50 & 3.14 & 1.38 & 1.72 & & \\
\hline 1967 & 2.93 & 3.89 & 3.47 & 2.46 & 2.32 & 1.76 & 0.15 & -0.29 & -2.27 & \\
\hline 1968 & 2.57 & 3.38 & 2.95 & 2.01 & 1.82 & 1.28 & -0.04 & -0.40 & -1.45 & -0.62 \\
\hline 1969 & 2.11 & 2.79 & 2.35 & 1.46 & 1.21 & 0.66 & -0.51 & -0.90 & -1.75 & -1.50 \\
\hline 1970 & 3.69 & 4.46 & 4.22 & 3.62 & 3.68 & 3.55 & 3.03 & 3.43 & 3.86 & 5.99 \\
\hline 1971 & 4.29 & 5.05 & 4.89 & 4.41 & 4.55 & 4.55 & 4.24 & 4.78 & 5.40 & 7.41 \\
\hline 1972 & 4.09 & 4.78 & 4.61 & 4.15 & 4.25 & 4.21 & 3.90 & 4.32 & 4.76 & 6.22 \\
\hline 1973 & 3.95 & 4.58 & 4.40 & 3.97 & 4.04 & 3.99 & 3.68 & 4.02 & 4.35 & 5.50 \\
\hline 1974 & 3.64 & 4.20 & 4.01 & 3.58 & 3.61 & 3.52 & 3.21 & 3.45 & 3.67 & 4.55 \\
\hline 1975 & 3.58 & 4.11 & 3.92 & 3.52 & 3.55 & 3.46 & 3.17 & 3.38 & 3.57 & 4.32 \\
\hline 1976 & 4.42 & 4.96 & 4.84 & 4.52 & 4.62 & 4.62 & 4.45 & 4.76 & 5.07 & 5.92 \\
\hline 1977 & 4.51 & 5.03 & 4.92 & 4.63 & 4.72 & 4.73 & 4.58 & 4.88 & 5.17 & 5.95 \\
\hline 1978 & 4.35 & 4.84 & 4.73 & 4.44 & 4.52 & 4.51 & 4.36 & 4.61 & 4.86 & 5.53 \\
\hline 1979 & 4.00 & 4.44 & 4.32 & 4.02 & 4.07 & 4.04 & 3.86 & 4.07 & 4.25 & 4.81 \\
\hline 1980 & 3.93 & 4.35 & 4.22 & 3.94 & 3.98 & 3.95 & 3.78 & 3.96 & 4.12 & 4.63 \\
\hline 1981 & 3.67 & 4.05 & 3.92 & 3.63 & 3.66 & 3.61 & 3.43 & 3.58 & 3.70 & 4.14 \\
\hline 1982 & 5.15 & 5.59 & 5.53 & 5.33 & 5.44 & 5.49 & 5.42 & 5.68 & 5.93 & 6.50 \\
\hline 1983 & 5.33 & 5.76 & 5.71 & 5.53 & 5.64 & 5.69 & 5.64 & 5.90 & 6.15 & 6.70 \\
\hline 1984 & 5.74 & 6.16 & 6.13 & 5.98 & 6.11 & 6.18 & 6.15 & 6.43 & 6.70 & 7.25 \\
\hline 1985 & 6.43 & 6.87 & 6.87 & 6.75 & 6.91 & 7.02 & 7.03 & 7.34 & 7.64 & 8.22 \\
\hline 1986 & 6.81 & 7.25 & 7.27 & 7.17 & 7.34 & 7.46 & 7.49 & 7.81 & 8.12 & 8.70 \\
\hline 1987 & 6.59 & 7.01 & 7.01 & 6.91 & 7.06 & 7.16 & 7.18 & 7.47 & 7.75 & 8.28 \\
\hline
\end{tabular}




\section{TABLE 5-7 (Continued)}

\begin{tabular}{|c|c|c|c|c|c|c|c|c|c|}
\hline $\begin{array}{l}\text { TO THE } \\
\text { END OF }\end{array}$ & $\begin{array}{l}\text { FROM } \\
1969\end{array}$ & $\begin{array}{c}\text { HE BEG } \\
1970\end{array}$ & $\begin{array}{l}\text { JNING OF } \\
1971\end{array}$ & 1972 & 1973 & 1974 & 1975 & 1976 & 1977 \\
\hline 1969 & -2.36 & & & & & & & & \\
\hline 1970 & 9.46 & 22.70 & & & & & & & \\
\hline 1971 & 10.23 & 17.12 & 11.79 & & & & & & \\
\hline 1972 & 8.00 & 11.70 & 6.57 & 1.59 & & & & & \\
\hline 1973 & 6.77 & 9.18 & 5.01 & 1.78 & 1.96 & & & & \\
\hline 1974 & 5.44 & 7.07 & 3.48 & 0.85 & 0.48 & -0.98 & & & \\
\hline 1975 & 5.05 & 6.33 & 3.33 & 1.32 & 1.23 & 0.86 & 2.74 & & \\
\hline 1976 & 6.77 & 8.14 & 5.89 & 4.74 & 5.55 & 6.77 & 10.87 & 19.65 & \\
\hline 1977 & 6.70 & 7.90 & 5.93 & 4.98 & 5.68 & 6.62 & 9.29 & 12.72 & 6.19 \\
\hline 1978 & 6.17 & 7.16 & 5.36 & 4.47 & 4.96 & 5.57 & 7.28 & 8.84 & 3.80 \\
\hline 1979 & 5.32 & 6.12 & 4.43 & 3.54 & 3.82 & 4.13 & 5.19 & 5.81 & 1.56 \\
\hline 1980 & 5.08 & 5.79 & 4.23 & 3.42 & 3.65 & 3.89 & 4.73 & 5.13 & 1.79 \\
\hline 1981 & 4.52 & 5.11 & 3.64 & 2.86 & 3.00 & 3.14 & 3.74 & 3.90 & 1.01 \\
\hline 1982 & 7.03 & 7.79 & 6.63 & 6.18 & 6.65 & 7.18 & 8.25 & 9.06 & 7.39 \\
\hline 1983 & 7.21 & 7.93 & 6.87 & 6.47 & 6.92 & 7.43 & 8.41 & 9.14 & 7.71 \\
\hline 1984 & 7.76 & 8.47 & 7.52 & 7.20 & 7.68 & 8.22 & 9.18 & 9.92 & 8.77 \\
\hline 1985 & 8.76 & 9.50 & 8.67 & 8.45 & 9.00 & 9.61 & 10.62 & 11.44 & 10.57 \\
\hline 1986 & 9.24 & 9.97 & 9.21 & 9.04 & 9.60 & 10.21 & 11.20 & 12.00 & 11.26 \\
\hline 1987 & 8.77 & 9.42 & 8.69 & 8.50 & 8.97 & 9.49 & 10.34 & 11.00 & 10.25 \\
\hline
\end{tabular}

\begin{tabular}{lrrrrrrrrrr} 
TO THE & \multicolumn{2}{c}{ FROM THE BEGINNING OF } & & & & & & \\
END OF & $\mathbf{1 9 7 8}$ & $\mathbf{1 9 7 9}$ & $\mathbf{1 9 8 0}$ & $\mathbf{1 9 8 1}$ & $\mathbf{1 9 8 2}$ & $\mathbf{1 9 8 3}$ & $\mathbf{1 9 8 4}$ & $\mathbf{1 9 8 5}$ & $\mathbf{1 9 8 6}$ & $\mathbf{1 9 8 7}$ \\
1978 & 1.47 & & & & & & & & & \\
1979 & -0.67 & -2.77 & & & & & & & & \\
1980 & 0.36 & -0.19 & 2.46 & & & & & & & \\
1981 & -0.24 & -0.80 & 0.20 & -2.02 & & & & & & \\
1982 & 7.63 & 9.22 & 13.54 & 19.52 & 45.81 & & & & & \\
1983 & 7.97 & 9.32 & 12.57 & 16.15 & 26.47 & 9.69 & & & & \\
1984 & 9.14 & 10.47 & 13.33 & 16.22 & 23.03 & 13.01 & 16.43 & & & \\
1985 & 11.13 & 12.58 & 15.37 & 18.13 & 23.79 & 17.22 & 21.17 & 26.10 & & \\
1986 & 11.84 & 13.21 & 15.70 & 18.06 & 22.55 & 17.34 & 20.00 & 21.83 & 17.70 & \\
1987 & 10.66 & 11.73 & 13.69 & 15.39 & 18.58 & 13.78 & 14.82 & 14.29 & 8.81 & 0.59
\end{tabular}


TABLE 5-8

LONG CANADA BONDS: REAL RETURNS RATES OF RETURN FOR VARIOUS HOLDING PERIODS FROM 1950 TO 1987

\begin{tabular}{|c|c|c|c|c|c|c|c|c|c|}
\hline $\begin{array}{l}\text { TO THE } \\
\text { END OF }\end{array}$ & $\begin{array}{l}\text { FROM } \\
1950\end{array}$ & $\underset{1951}{\text { THE BEG }}$ & $\begin{array}{l}1952 \\
\text { NNING OF }\end{array}$ & 1953 & 1954 & 1955 & 1956 & 1957 & 1958 \\
\hline 1950 & -5.85 & & & & & & & & \\
\hline 1951 & -9.19 & -12.41 & & & & & & & \\
\hline 1952 & -5.04 & -4.63 & 3.84 & & & & & & \\
\hline 1953 & -2.91 & -1.91 & 3.80 & 3.76 & & & & & \\
\hline 1954 & -0.56 & 0.80 & 5.63 & 6.54 & 9.40 & & & & \\
\hline 1955 & -0.60 & 0.48 & 3.99 & 4.04 & 4.18 & -0.78 & & & \\
\hline 1956 & -1.46 & -0.71 & 1.81 & 1.31 & 0.50 & -3.67 & -6.49 & & \\
\hline 1957 & -0.74 & 0.01 & 2.25 & 1.93 & 1.48 & -1.03 & -1.16 & 4.48 & \\
\hline 1958 & -1.60 & -1.06 & 0.68 & 0.16 & -0.55 & -2.89 & -3.58 & -2.09 & -8.25 \\
\hline 1959 & -2.02 & -1.58 & -0.14 & -0.69 & -1.42 & -3.45 & -4.10 & -3.30 & -6.96 \\
\hline 1960 & -1.35 & -0.89 & 0.48 & 0.06 & -0.45 & -2.01 & -2.25 & -1.16 & -2.97 \\
\hline 1961 & -0.50 & 0.00 & 1.34 & 1.06 & 0.73 & -0.45 & -0.40 & 0.87 & -0.02 \\
\hline 1962 & -0.34 & 0.13 & 1.36 & 1.11 & 0.82 & -0.20 & -0.12 & 0.98 & 0.30 \\
\hline 1963 & -0.13 & 0.33 & 1.47 & 1.25 & 1.01 & 0.11 & 0.23 & 1.22 & 0.69 \\
\hline 1964 & 0.19 & 0.64 & 1.72 & 1.55 & 1.35 & 0.58 & 0.73 & 1.67 & 1.27 \\
\hline 1965 & 0.06 & 0.47 & 1.46 & 1.28 & 1.07 & 0.35 & 0.46 & 1.27 & 0.87 \\
\hline 1966 & -0.04 & 0.33 & 1.25 & 1.06 & 0.86 & 0.18 & 0.27 & 0.97 & 0.58 \\
\hline 1967 & -0.39 & -0.06 & 0.76 & 0.56 & 0.34 & -0.33 & -0.29 & 0.29 & -0.12 \\
\hline 1968 & -0.61 & -0.31 & 0.45 & 0.24 & 0.01 & -0.63 & -0.62 & -0.11 & -0.52 \\
\hline 1969 & -0.93 & -0.66 & 0.04 & -0.18 & -0.42 & -1.05 & -1.07 & -0.64 & -1.05 \\
\hline 1970 & 0.02 & 0.32 & 1.04 & 0.89 & 0.72 & 0.20 & 0.27 & 0.77 & 0.49 \\
\hline 1971 & 0.31 & 0.61 & 1.31 & 1.18 & 1.04 & 0.57 & 0.65 & 1.15 & 0.91 \\
\hline 1972 & 0.15 & 0.43 & 1.08 & 0.95 & 0.80 & 0.34 & 0.41 & 0.86 & 0.62 \\
\hline 1973 & -0.15 & 0.11 & 0.72 & 0.57 & 0.41 & -0.04 & 0.00 & 0.40 & 0.15 \\
\hline 1974 & -0.64 & -0.42 & 0.14 & -0.03 & -0.21 & -0.66 & -0.66 & -0.32 & -0.60 \\
\hline 1975 & -0.86 & -0.66 & -0.14 & -0.31 & -0.49 & -0.94 & -0.94 & -0.64 & -0.92 \\
\hline 1976 & -0.38 & -0.17 & 0.36 & 0.21 & 0.06 & -0.34 & -0.32 & 0.00 & -0.23 \\
\hline 1977 & -0.48 & -0.27 & 0.23 & 0.08 & -0.07 & -0.46 & -0.44 & -0.15 & -0.37 \\
\hline 1978 & -0.69 & -0.50 & -0.03 & -0.17 & -0.33 & -0.71 & -0.71 & -0.44 & -0.67 \\
\hline 1979 & -1.07 & -0.90 & -0.46 & -0.61 & -0.78 & -1.17 & -1.18 & -0.94 & -1.18 \\
\hline 1980 & -1.29 & -1.14 & -0.72 & -0.88 & -1.05 & -1.43 & -1.46 & -1.24 & -1.48 \\
\hline 1981 & -1.67 & -1.53 & -1.14 & -1.31 & -1.49 & -1.87 & -1.91 & -1.72 & -1.97 \\
\hline 1982 & -0.75 & -0.59 & -0.18 & -0.31 & -0.45 & -0.79 & -0.79 & -0.56 & -0.76 \\
\hline 1983 & -0.59 & -0.43 & -0.03 & -0.15 & -0.28 & -0.59 & -0.59 & -0.36 & -0.54 \\
\hline 1984 & -0.25 & -0.08 & 0.32 & 0.22 & 0.10 & -0.19 & -0.17 & 0.06 & -0.10 \\
\hline 1985 & 0.29 & 0.47 & 0.87 & 0.79 & 0.69 & 0.43 & 0.47 & 0.71 & 0.58 \\
\hline 1986 & 0.61 & 0.80 & 1.20 & 1.13 & 1.05 & 0.80 & 0.85 & 1.10 & 0.99 \\
\hline 1987 & 0.50 & 0.68 & 1.07 & 0.99 & 0.91 & 0.67 & 0.71 & 0.95 & 0.84 \\
\hline
\end{tabular}




\section{TABLE 5-8 (Continued)}

\begin{tabular}{|c|c|c|c|c|c|c|c|c|c|c|}
\hline TO THE & FROM & THE BI & GINNIN & & & & & & & \\
\hline END OF & 1959 & 1960 & 1961 & 1962 & 1963 & 1964 & 1965 & 1966 & 1967 & 1968 \\
\hline 1959 & -5.66 & & & & & & & & & \\
\hline 1960 & -0.22 & 5.53 & & & & & & & & \\
\hline 1961 & 2.89 & 7.45 & 9.41 & & & & & & & \\
\hline 1962 & 2.56 & 5.45 & 5.41 & 1.56 & & & & & & \\
\hline 1963 & 2.58 & 4.75 & 4.50 & 2.12 & 2.68 & & & & & \\
\hline 1964 & 2.96 & 4.77 & 4.58 & 3.02 & 3.75 & 4.83 & & & & \\
\hline 1965 & 2.25 & 3.63 & 3.25 & 1.77 & 1.84 & 1.42 & -1.89 & & & \\
\hline 1966 & 1.75 & 2.85 & 2.41 & 1.07 & 0.94 & 0.37 & -1.79 & -1.70 & & \\
\hline 1967 & 0.83 & 1.67 & 1.13 & -0.18 & -0.53 & -1.32 & -3.29 & -3.98 & -6.21 & \\
\hline 1968 & 0.29 & 0.97 & 0.41 & -0.81 & -1.20 & -1.96 & -3.59 & -4.15 & -5.35 & -4.48 \\
\hline 1969 & -0.37 & 0.18 & -0.40 & -1.57 & -2.00 & -2.76 & -4.22 & -4.79 & -5.80 & -5.60 \\
\hline 1970 & 1.25 & 1.90 & 1.55 & 0.71 & 0.60 & 0.31 & -0.42 & -0.13 & 0.27 & 2.52 \\
\hline 1971 & 1.65 & 2.29 & 2.00 & 1.28 & 1.25 & 1.08 & 0.55 & 0.96 & 1.50 & 3.53 \\
\hline 1972 & 1.29 & 1.84 & 1.54 & 0.86 & 0.78 & 0.58 & 0.06 & 0.34 & 0.68 & 2.12 \\
\hline 1973 & 0.74 & 1.21 & 0.88 & 0.20 & 0.08 & -0.18 & -0.72 & -0.57 & -0.41 & 0.59 \\
\hline 1974 & -0.10 & 0.28 & -0.08 & -0.78 & -0.97 & -1.30 & -1.89 & -1.89 & -1.91 & -1.29 \\
\hline 1975 & -0.47 & -0.14 & -0.50 & -1.18 & -1.38 & -1.72 & -2.29 & -2.33 & -2.40 & -1.91 \\
\hline 1976 & 0.23 & 0.59 & 0.29 & -0.29 & -0.42 & -0.66 & -1.10 & -1.03 & -0.96 & -0.36 \\
\hline 1977 & 0.06 & 0.39 & 0.09 & -0.46 & -0.60 & -0.83 & -1.25 & -1.19 & -1.15 & -0.63 \\
\hline 1978 & -0.27 & 0.02 & -0.28 & -0.82 & -0.97 & -1.20 & -1.62 & -1.60 & -1.59 & -1.16 \\
\hline 1979 & -0.83 & -0.59 & -0.90 & -1.44 & -1.62 & -1.88 & -2.31 & -2.34 & -2.39 & -2.06 \\
\hline 1980 & -1.16 & -0.94 & -1.26 & -1.79 & -1.97 & -2.24 & -2.67 & -2.72 & -2.79 & -2.52 \\
\hline 1981 & -1.69 & -1.51 & -1.83 & -2.36 & -2.56 & -2.85 & -3.28 & -3.37 & -3.48 & -3.28 \\
\hline 1982 & -0.43 & -0.20 & -0.45 & -0.90 & -1.02 & -1.21 & -1.53 & -1.51 & -1.50 & -1.18 \\
\hline 1983 & -0.22 & 0.01 & -0.22 & -0.64 & -0.74 & -0.91 & -1.20 & -1.17 & -1.14 & -0.81 \\
\hline 1984 & 0.23 & 0.47 & 0.27 & -0.11 & -0.19 & -0.32 & -0.57 & -0.50 & -0.44 & -0.09 \\
\hline 1985 & 0.93 & 1.19 & 1.02 & 0.68 & 0.65 & 0.55 & 0.35 & 0.47 & 0.58 & 0.97 \\
\hline 1986 & 1.33 & 1.60 & 1.45 & 1.15 & 1.13 & 1.06 & 0.90 & 1.03 & 1.17 & 1.57 \\
\hline 1987 & 1.17 & 1.42 & 1.27 & 0.97 & 0.95 & 0.87 & 0.70 & 0.82 & 0.95 & 1.32 \\
\hline
\end{tabular}




\section{TABLE 5-8 (Continued)}

\begin{tabular}{|c|c|c|c|c|c|c|c|c|c|}
\hline TO THE & FROM & IE BEC & NING OF & & & & & & \\
\hline END UF & & 1970 & 1971 & 1972 & 1973 & 1974 & 1975 & 1976 & 1977 \\
\hline 1969 & -6.70 & & & & & & & & \\
\hline 1970 & 6.21 & 20.91 & & & & & & & \\
\hline 1971 & 6.34 & 13.53 & 6.61 & & & & & & \\
\hline 1972 & 3.83 & 7.60 & 1.51 & -3.34 & & & & & \\
\hline 1973 & 1.64 & 3.84 & -1.30 & -5.03 & -6.69 & & & & \\
\hline 1974 & -0.74 & 0.49 & -4.05 & -7.36 & -9.30 & -11.85 & & & \\
\hline 1975 & -1.54 & -0.66 & -4.48 & -7.07 & -8.28 & -9.07 & -6.20 & & \\
\hline 1976 & 0.16 & 1.19 & -1.77 & -3.37 & -3.38 & -2.25 & 2.94 & 12.97 & \\
\hline 1977 & -0.19 & 0.65 & -1.95 & -3.31 & -3.30 & -2.43 & 0.92 & 4.69 & -2.99 \\
\hline 1978 & -0.83 & -0.15 & -2.51 & -3.75 & -3.81 & -3.23 & -0.95 & 0.87 & -4.69 \\
\hline 1979 & -1.84 & -1.34 & -3.55 & -4.75 & -4.95 & -4.65 & -3.14 & -2.36 & -7.00 \\
\hline 1980 & -2.36 & -1.95 & -3.99 & -5.10 & -5.31 & -5.12 & -3.94 & -3.49 & -7.21 \\
\hline 1981 & -3.19 & -2.89 & -4.80 & -5.87 & -6.15 & -6.08 & -5.23 & -5.07 & -8.31 \\
\hline 1982 & -0.94 & -0.48 & -2.09 & -2.84 & -2.79 & -2.35 & -1.09 & -0.34 & -2.40 \\
\hline 1983 & -0.56 & -0.11 & -1.56 & -2.22 & -2.11 & -1.64 & -0.44 & 0.31 & -1.38 \\
\hline 1984 & 0.19 & 0.67 & -0.64 & -1.17 & -0.99 & -0.46 & 0.76 & 1.56 & 0.22 \\
\hline 1985 & 1.30 & 1.83 & 0.67 & 0.26 & 0.54 & 1.16 & 2.44 & 3.35 & 2.33 \\
\hline 1986 & 1.92 & 2.45 & 1.40 & 1.06 & 1.38 & 2.03 & 3.28 & 4.19 & 3.35 \\
\hline 1987 & 1.63 & 2.12 & 1.11 & 0.77 & 1.05 & 1.63 & 2.75 & 3.53 & 2.71 \\
\hline
\end{tabular}

\begin{tabular}{|c|c|c|c|c|c|c|c|c|c|c|}
\hline TO THE & FROM & THE B & GINNIN & $\mathrm{OF}$ & & & & & & \\
\hline END OF & 1978 & 1979 & 1980 & 1981 & 1982 & 1983 & 1984 & 1985 & 1986 & 1987 \\
\hline 1978 & -6.36 & & & & & & & & & \\
\hline 1979 & -8.94 & -11.45 & & & & & & & & \\
\hline 1980 & -8.58 & -9.67 & -7.85 & & & & & & & \\
\hline 1981 & -9.60 & -10.66 & -10.25 & -12.60 & & & & & & \\
\hline 1982 & -2.28 & -1.23 & 2.43 & 8.00 & 33.44 & & & & & \\
\hline 1983 & -1.11 & -0.03 & 3.05 & 6.96 & 18.33 & 4.93 & & & & \\
\hline 1984 & 0.69 & 1.91 & 4.82 & 8.25 & 16.25 & 8.51 & 12.21 & & & \\
\hline 1985 & 3.01 & 4.43 & 7.34 & 10.66 & 17.38 & 12.47 & 16.45 & 20.85 & & \\
\hline 1986 & 4.08 & 5.46 & 8.12 & 11.04 & 16.49 & 12.60 & 15.28 & 16.85 & 12.98 & \\
\hline 1987 & 3.30 & 4.43 & 6.61 & 8.85 & 12.91 & 9.20 & 10.29 & 9.66 & 4.46 & -3.42 \\
\hline
\end{tabular}


TABLE 5-9

PROVINCIAL BONDS: TOTAL RETURNS RATES OF RETURN FOR VARIOUS HOLDING PERIODS FROM 1950 TO 1987

\begin{tabular}{|c|c|c|c|c|c|c|c|c|c|}
\hline $\begin{array}{l}\text { TO THE } \\
\text { END OF }\end{array}$ & $\begin{array}{l}\text { FROM } \\
1950\end{array}$ & $\begin{array}{c}\text { HE BEC } \\
1951\end{array}$ & $\begin{array}{l}\text { NING OF } \\
1952\end{array}$ & 1953 & 1954 & 1955 & 1956 & 1957 & 1958 \\
\hline 1950 & 0.00 & & & & & & & & \\
\hline 1951 & -4.06 & -7.95 & & & & & & & \\
\hline 1952 & -1.15 & -1.72 & 4.94 & & & & & & \\
\hline 1953 & 0.41 & 0.54 & 5.08 & 5.22 & & & & & \\
\hline 1954 & 2.88 & 3.62 & 7.79 & 9.24 & 13.42 & & & & \\
\hline 1955 & 1.94 & 2.33 & 5.08 & 5.12 & 5.08 & -2.65 & & & \\
\hline 1956 & 0.18 & 0.21 & 1.93 & 1.19 & -0.12 & -6.27 & -9.75 & & \\
\hline 1957 & 1.41 & 1.61 & 3.30 & 2.98 & 2.43 & -1.00 & -0.16 & 10.45 & \\
\hline 1958 & 1.09 & 1.22 & 2.61 & 2.22 & 1.64 & -1.11 & -0.59 & 4.32 & -1.46 \\
\hline 1959 & 0.47 & 0.52 & 1.63 & 1.17 & 0.51 & -1.89 & -1.70 & 1.13 & -3.23 \\
\hline 1960 & 1.36 & 1.50 & 2.61 & 2.32 & 1.91 & 0.11 & 0.67 & 3.46 & 1.23 \\
\hline 1961 & 2.01 & 2.19 & 3.26 & 3.08 & 2.82 & 1.38 & 2.07 & 4.62 & 3.21 \\
\hline 1962 & 2.21 & 2.40 & 3.39 & 3.24 & 3.02 & 1.79 & 2.44 & 4.63 & 3.50 \\
\hline 1963 & 2.37 & 2.56 & 3.48 & 3.35 & 3.17 & 2.09 & 2.70 & 4.61 & 3.67 \\
\hline 1964 & 2.68 & 2.87 & 3.76 & 3.66 & 3.52 & 2.58 & 3.17 & 4.91 & 4.15 \\
\hline 1965 & 2.53 & 2.70 & 3.50 & 3.39 & 3.24 & 2.37 & 2.88 & 4.39 & 3.65 \\
\hline 1966 & 2.30 & 2.44 & 3.17 & 3.05 & 2.88 & 2.05 & 2.49 & 3.80 & 3.09 \\
\hline 1967 & 2.17 & 2.30 & 2.98 & 2.85 & 2.68 & 1.90 & 2.29 & 3.46 & 2.79 \\
\hline 1968 & 2.14 & 2.26 & 2.90 & 2.77 & 2.61 & 1.88 & 2.23 & 3.30 & 2.68 \\
\hline 1969 & 1.88 & 1.98 & 2.57 & 2.43 & 2.26 & 1.55 & 1.86 & 2.81 & 2.20 \\
\hline 1970 & 2.63 & 2.77 & 3.36 & 3.28 & 3.16 & 2.55 & 2.91 & 3.88 & 3.39 \\
\hline 1971 & 3.10 & 3.25 & 3.84 & 3.78 & 3.70 & 3.16 & 3.53 & 4.49 & 4.07 \\
\hline 1972 & 3.26 & 3.41 & 3.98 & 3.93 & 3.87 & 3.36 & 3.72 & 4.63 & 4.25 \\
\hline 1973 & 3.16 & 3.30 & 3.84 & 3.79 & 3.72 & 3.23 & 3.57 & 4.41 & 4.05 \\
\hline 1974 & 2.93 & 3.06 & 3.56 & 3.50 & 3.42 & 2.94 & 3.25 & 4.02 & 3.66 \\
\hline 1975 & 3.09 & 3.22 & 3.71 & 3.66 & 3.59 & 3.14 & 3.44 & 4.18 & 3.85 \\
\hline 1976 & 3.71 & 3.86 & 4.36 & 4.34 & 4.30 & 3.90 & 4.23 & 4.98 & 4.70 \\
\hline 1977 & 3.90 & 4.05 & 4.54 & 4.52 & 4.49 & 4.12 & 4.44 & 5.17 & 4.91 \\
\hline 1978 & 3.90 & 4.04 & 4.51 & 4.49 & 4.46 & 4.11 & 4.41 & 5.11 & 4.86 \\
\hline 1979 & 3.66 & 3.79 & 4.24 & 4.21 & 4.17 & 3.82 & 4.10 & 4.75 & 4.49 \\
\hline 1980 & 3.64 & 3.76 & 4.19 & 4.17 & 4.13 & 3.79 & 4.05 & 4.67 & 4.43 \\
\hline 1981 & 3.45 & 3.56 & 3.97 & 3.93 & 3.89 & 3.55 & 3.80 & 4.38 & 4.13 \\
\hline 1982 & 4.53 & 4.68 & 5.11 & 5.12 & 5.11 & 4.83 & 5.12 & 5.74 & 5.55 \\
\hline 1983 & 4.70 & 4.85 & 5.28 & 5.29 & 5.29 & 5.02 & 5.30 & 5.91 & 5.74 \\
\hline 1984 & 5.06 & 5.22 & 5.64 & 5.66 & 5.68 & 5.43 & 5.72 & 6.32 & 6.17 \\
\hline 1985 & 5.60 & 5.76 & 6.19 & 6.23 & 6.26 & 6.04 & 6.34 & 6.95 & 6.82 \\
\hline 1986 & 5.88 & 6.05 & 6.48 & 6.52 & 6.56 & 6.35 & 6.66 & 7.25 & 7.14 \\
\hline 1987 & 5.77 & 5.93 & 6.34 & 6.38 & 6.41 & 6.21 & 6.50 & 7.07 & 6.96 \\
\hline
\end{tabular}


TABLE 5-9 (Continued)

\begin{tabular}{|c|c|c|c|c|c|c|c|c|c|c|}
\hline TO THE & FROM & THE B & IINNIN & OF & & & & & & \\
\hline END OF & 1959 & 1960 & 1961 & 1962 & 1963 & 1964 & 1965 & 1966 & 1967 & 1968 \\
\hline 1959 & -4.96 & & & & & & & & & \\
\hline 1960 & 2.61 & 10.78 & & & & & & & & \\
\hline 1961 & 4.81 & 10.07 & 9.36 & & & & & & & \\
\hline 1962 & 4.78 & 8.25 & 7.01 & 4.70 & & & & & & \\
\hline 1963 & 4.72 & 7.30 & 6.16 & 4.59 & 4.49 & & & & & \\
\hline 1964 & 5.11 & 7.25 & 6.38 & 5.41 & 5.77 & 7.06 & & & & \\
\hline 1965 & 4.41 & 6.06 & 5.14 & 4.10 & 3.91 & 3.62 & 0.29 & & & \\
\hline 1966 & 3.67 & 4.97 & 4.03 & 2.99 & 2.57 & 1.94 & -0.53 & -1.33 & & \\
\hline 1967 & 3.27 & 4.35 & 3.46 & 2.50 & 2.07 & 1.48 & -0.32 & -0.62 & 0.10 & \\
\hline 1968 & 3.10 & 4.04 & 3.22 & 2.37 & 1.99 & 1.50 & 0.15 & 0.11 & 0.84 & 1.59 \\
\hline 1969 & 2.54 & 3.32 & 2.52 & 1.70 & 1.28 & 0.75 & -0.46 & -0.65 & -0.42 & -0.68 \\
\hline 1970 & 3.81 & 4.64 & 4.05 & 3.47 & 3.32 & 3.16 & 2.52 & 2.97 & 4.08 & 5.44 \\
\hline 1971 & 4.51 & 5.34 & 4.86 & 4.42 & 4.39 & 4.38 & 4.00 & 4.63 & 5.87 & 7.36 \\
\hline 1972 & 4.67 & 5.45 & 5.02 & 4.64 & 4.63 & 4.65 & 4.35 & 4.94 & 6.03 & 7.25 \\
\hline 1973 & 4.43 & 5.13 & 4.71 & 4.33 & 4.30 & 4.28 & 3.97 & 4.44 & 5.30 & 6.19 \\
\hline 1974 & 3.98 & 4.61 & 4.18 & 3.79 & 3.72 & 3.65 & 3.31 & 3.66 & 4.30 & 4.91 \\
\hline 1975 & 4.17 & 4.77 & 4.38 & 4.03 & 3.98 & 3.94 & 3.66 & 4.00 & 4.61 & 5.19 \\
\hline 1976 & 5.05 & 5.67 & 5.36 & 5.10 & 5.13 & 5.18 & 5.03 & 5.47 & 6.17 & 6.87 \\
\hline 1977 & 5.26 & 5.86 & 5.58 & 5.34 & 5.39 & 5.45 & 5.33 & 5.76 & 6.43 & 7.08 \\
\hline 1978 & 5.18 & 5.75 & 5.47 & 5.25 & 5.28 & 5.34 & 5.22 & 5.60 & 6.20 & 6.78 \\
\hline 1979 & 4.79 & 5.30 & 5.02 & 4.78 & 4.79 & 4.81 & 4.66 & 4.98 & 5.48 & 5.94 \\
\hline 1980 & 4.70 & 5.19 & 4.91 & 4.69 & 4.68 & 4.70 & 4.55 & 4.84 & 5.30 & 5.71 \\
\hline 1981 & 4.39 & 4.83 & 4.56 & 4.32 & 4.30 & 4.29 & 4.13 & 4.38 & 4.77 & 5.11 \\
\hline 1982 & 5.85 & 6.35 & 6.15 & 6.00 & 6.07 & 6.15 & 6.10 & 6.46 & 6.96 & 7.44 \\
\hline 1983 & 6.03 & 6.52 & 6.34 & 6.20 & 6.27 & 6.36 & 6.33 & 6.67 & 7.16 & 7.62 \\
\hline 1984 & 6.48 & 6.96 & 6.80 & 6.69 & 6.79 & 6.90 & 6.89 & 7.25 & 7.75 & 8.21 \\
\hline 1985 & 7.14 & 7.64 & 7.51 & 7.44 & 7.56 & 7.70 & 7.73 & 8.12 & 8.64 & 9.14 \\
\hline 1986 & 7.47 & 7.96 & 7.85 & 7.79 & 7.92 & 8.07 & 8.12 & 8.51 & 9.02 & 9.51 \\
\hline 1987 & 7.26 & 7.72 & 7.61 & 7.55 & 7.66 & 7.80 & 7.83 & 8.18 & 8.66 & 9.11 \\
\hline
\end{tabular}




\section{TABLE 5-9 (Continued)}

\begin{tabular}{|c|c|c|c|c|c|c|c|c|c|}
\hline TO THE & FROM & HE BEG & JNING OF & & & & & & \\
\hline END OF & 1969 & 1970 & 1971 & 1972 & 1973 & 1974 & 1975 & 1976 & 1977 \\
\hline 1969 & -2.90 & & & & & & & & \\
\hline 1970 & 7.42 & 18.83 & & & & & & & \\
\hline 1971 & 9.35 & 16.05 & 13.33 & & & & & & \\
\hline 1972 & 8.72 & 12.89 & 10.03 & 6.83 & & & & & \\
\hline 1973 & 7.13 & 9.80 & 6.94 & 3.88 & 1.02 & & & & \\
\hline 1974 & 5.48 & 7.24 & 4.52 & 1.74 & -0.72 & -2.42 & & & \\
\hline 1975 & 5.71 & 7.22 & 5.04 & 3.06 & 1.84 & 2.25 & 7.14 & & \\
\hline 1976 & 7.55 & 9.13 & 7.59 & 6.48 & 6.40 & 8.25 & 14.02 & 21.34 & \\
\hline 1977 & 7.71 & 9.12 & 7.80 & 6.90 & 6.91 & 8.44 & 12.33 & 15.01 & 9.02 \\
\hline 1978 & 7.31 & 8.51 & 7.28 & 6.45 & 6.38 & 7.49 & 10.12 & 11.14 & 6.36 \\
\hline 1979 & 6.34 & 7.31 & 6.11 & 5.24 & 5.01 & 5.69 & 7.39 & 7.46 & 3.19 \\
\hline 1980 & 6.06 & 6.91 & 5.79 & 4.98 & 4.75 & 5.30 & 6.64 & 6.55 & 3.14 \\
\hline 1981 & 5.39 & 6.11 & 5.02 & 4.22 & 3.94 & 4.31 & 5.31 & 5.01 & 2.01 \\
\hline 1982 & 7.87 & 8.74 & 7.94 & 7.46 & 7.53 & 8.28 & 9.69 & 10.07 & 8.29 \\
\hline 1983 & 8.04 & 8.86 & 8.13 & 7.71 & 7.79 & 8.49 & 9.78 & 10.11 & 8.60 \\
\hline 1984 & 8.64 & 9.46 & 8.82 & 8.48 & 8.62 & 9.33 & 10.59 & 10.97 & 9.74 \\
\hline 1985 & 9.60 & 10.43 & 9.89 & 9.65 & 9.87 & 10.64 & 11.91 & 12.40 & 11.45 \\
\hline 1986 & 9.97 & 10.78 & 10.29 & 10.10 & 10.33 & 11.08 & 12.29 & 12.77 & 11.95 \\
\hline 1987 & 9.52 & 10.25 & 9.77 & 9.55 & 9.73 & 10.38 & 11.43 & 11.80 & 10.97 \\
\hline
\end{tabular}

TO THE FROM THE BEGINNING OF

$\begin{array}{lrrrrrrrrrr}\text { END OF } & \mathbf{1 9 7 8} & \mathbf{1 9 7 9} & \mathbf{1 9 8 0} & \mathbf{1 9 8 1} & \mathbf{1 9 8 2} & \mathbf{1 9 8 3} & \mathbf{1 9 8 4} & \mathbf{1 9 8 5} & \mathbf{1 9 8 6} & \mathbf{1 9 8 7} \\ 1978 & 3.77 & & & & & & & & & \\ 1979 & 0.40 & -2.86 & & & & & & & & \\ 1980 & 1.25 & 0.01 & 2.97 & & & & & & & \\ 1981 & 0.33 & -0.79 & 0.27 & -2.37 & & & & & & \\ 1982 & 8.15 & 9.27 & 13.64 & 19.38 & 45.98 & & & & & \\ 1983 & 8.53 & 9.51 & 12.84 & 16.33 & 26.98 & 10.46 & & & & \\ 1984 & 9.85 & 10.89 & 13.87 & 16.77 & 23.95 & 14.22 & 18.11 & & & \\ 1985 & 11.76 & 12.95 & 15.82 & 18.58 & 24.48 & 18.04 & 22.02 & 26.07 & & \\ 1986 & 12.28 & 13.39 & 15.92 & 18.24 & 22.85 & 17.67 & 20.17 & 21.22 & 16.55 & \\ 1987 & 11.17 & 12.02 & 14.04 & 15.71 & 19.04 & 14.28 & 15.25 & 14.31 & 8.85 & 1.66\end{array}$


TABLE 5-10

PROVINCIAL BONDS: REAL RETURNS RATES OF RETURN FOR VARIOUS HOLDING PERIODS FROM 1950 TO 1987

\begin{tabular}{|c|c|c|c|c|c|c|c|c|c|}
\hline $\begin{array}{l}\text { TO THE } \\
\text { END OF }\end{array}$ & $\begin{array}{l}\text { FROM ' } \\
1950\end{array}$ & $\begin{array}{c}\text { IHE BEG } \\
1951\end{array}$ & $\begin{array}{l}\text { NING OF } \\
1952\end{array}$ & 1953 & 1954 & 1955 & 1956 & 1957 & 1958 \\
\hline 1950 & -5.75 & & & & & & & & \\
\hline 1951 & -11.48 & -16.87 & & & & & & & \\
\hline 1952 & -5.77 & -5.78 & 6.79 & & & & & & \\
\hline 1953 & -3.14 & -2.25 & 6.00 & 5.22 & & & & & \\
\hline 1954 & -0.10 & 1.36 & 8.29 & 9.05 & 13.02 & & & & \\
\hline 1955 & -0.59 & 0.48 & 5.35 & 4.88 & 4.71 & -2.99 & & & \\
\hline 1956 & -2.38 & -1.81 & 1.51 & 0.23 & -1.37 & -7.87 & -12.50 & & \\
\hline 1957 & -1.11 & -0.43 & 2.60 & 1.79 & 0.95 & -2.78 & -2.68 & 8.25 & \\
\hline 1958 & -1.44 & -0.89 & 1.63 & 0.80 & -0.06 & -3.09 & -3.12 & 1.93 & -4.01 \\
\hline 1959 & -1.93 & -1.49 & 0.62 & -0.23 & -1.11 & -3.72 & -3.90 & -0.84 & -5.10 \\
\hline 1960 & -0.95 & -0.45 & 1.56 & 0.92 & 0.33 & -1.65 & -1.38 & 1.62 & -0.50 \\
\hline 1961 & -0.15 & 0.37 & 2.28 & 1.79 & 1.37 & -0.19 & 0.28 & 3.06 & 1.80 \\
\hline 1962 & 0.09 & 0.59 & 2.35 & 1.92 & 1.56 & 0.21 & 0.68 & 3.06 & 2.05 \\
\hline 1963 & 0.27 & 0.75 & 2.37 & 1.98 & 1.66 & 0.47 & 0.92 & 2.99 & 2.14 \\
\hline 1964 & 0.59 & 1.05 & 2.58 & 2.24 & 1.97 & 0.93 & 1.38 & 3.26 & 2.57 \\
\hline 1965 & 0.38 & 0.81 & 2.20 & 1.86 & 1.58 & 0.60 & 0.97 & 2.59 & 1.90 \\
\hline 1966 & 0.08 & 0.46 & 1.73 & 1.38 & 1.09 & 0.15 & 0.45 & 1.84 & 1.15 \\
\hline 1967 & -0.15 & 0.19 & 1.37 & 1.02 & 0.72 & -0.17 & 0.07 & 1.30 & 0.63 \\
\hline 1968 & -0.27 & 0.05 & 1.14 & 0.80 & 0.51 & -0.32 & -0.12 & 0.99 & 0.36 \\
\hline 1969 & -0.62 & -0.35 & 0.66 & 0.31 & 0.01 & -0.80 & -0.64 & 0.34 & -0.30 \\
\hline 1970 & 0.15 & 0.46 & 1.47 & 1.18 & 0.95 & 0.23 & 0.45 & 1.45 & 0.94 \\
\hline 1971 & 0.50 & 0.81 & 1.79 & 1.53 & 1.33 & 0.68 & 0.91 & 1.88 & 1.44 \\
\hline 1972 & 0.55 & 0.85 & 1.78 & 1.54 & 1.34 & 0.73 & 0.96 & 1.86 & 1.45 \\
\hline 1973 & 0.20 & 0.47 & 1.34 & 1.08 & 0.88 & 0.28 & 0.46 & 1.28 & 0.86 \\
\hline 1974 & -0.37 & -0.14 & 0.66 & 0.39 & 0.16 & -0.44 & -0.30 & 0.42 & -0.02 \\
\hline 1975 & -0.44 & -0.22 & 0.54 & 0.28 & 0.06 & -0.52 & -0.40 & 0.28 & -0.14 \\
\hline 1976 & 0.08 & 0.31 & 1.07 & 0.83 & 0.65 & 0.12 & 0.27 & 0.95 & 0.58 \\
\hline 1977 & 0.06 & 0.28 & 1.01 & 0.78 & 0.60 & 0.10 & 0.24 & 0.89 & 0.53 \\
\hline 1978 & -0.09 & 0.12 & 0.81 & 0.59 & 0.41 & -0.09 & 0.04 & 0.65 & 0.30 \\
\hline 1979 & -0.49 & -0.31 & 0.34 & 0.11 & -0.08 & -0.57 & -0.47 & 0.09 & -0.27 \\
\hline 1980 & -0.73 & -0.55 & 0.06 & -0.17 & -0.36 & -0.84 & -0.76 & -0.24 & -0.59 \\
\hline 1981 & -1.13 & -0.98 & -0.40 & -0.64 & -0.84 & -1.32 & -1.26 & -0.78 & -1.14 \\
\hline 1982 & -0.22 & -0.05 & 0.55 & 0.35 & 0.18 & -0.25 & -0.14 & 0.37 & 0.06 \\
\hline 1983 & -0.06 & 0.12 & 0.71 & 0.52 & 0.36 & -0.05 & 0.06 & 0.56 & 0.27 \\
\hline 1984 & 0.32 & 0.50 & 1.08 & 0.91 & 0.77 & 0.39 & 0.50 & 1.00 & 0.74 \\
\hline 1985 & 0.84 & 1.03 & 1.61 & 1.46 & 1.34 & 0.99 & 1.12 & 1.63 & 1.40 \\
\hline 1986 & 1.12 & 1.32 & 1.89 & 1.75 & 1.65 & 1.31 & 1.45 & 1.95 & 1.74 \\
\hline 1987 & 1.03 & 1.21 & 1.77 & 1.63 & 1.53 & 1.20 & 1.33 & 1.81 & 1.60 \\
\hline
\end{tabular}


TABLE 5-10 (Continued)

\begin{tabular}{|c|c|c|c|c|c|c|c|c|c|c|}
\hline TO THE & FROM & THE B & GINNI & 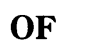 & & & & & & \\
\hline END OF & 1959 & 1960 & 1961 & 1962 & 1963 & 1964 & 1965 & 1966 & 1967 & 1968 \\
\hline 1959 & -6.18 & & & & & & & & & \\
\hline 1960 & 1.30 & 9.38 & & & & & & & & \\
\hline 1961 & 3.81 & 9.20 & 9.02 & & & & & & & \\
\hline 1962 & 3.63 & 7.12 & 6.01 & 3.08 & & & & & & \\
\hline 1963 & 3.42 & 5.97 & 4.85 & 2.83 & 2.58 & & & & & \\
\hline 1964 & 3.70 & 5.80 & 4.93 & 3.60 & 3.85 & 5.14 & & & & \\
\hline 1965 & 2.78 & 4.35 & 3.37 & 2.01 & 1.65 & 1.19 & -2.62 & & & \\
\hline 1966 & 1.82 & 3.01 & 1.99 & 0.64 & 0.04 & -0.80 & -3.64 & -4.65 & & \\
\hline 1967 & 1.16 & 2.12 & 1.12 & -0.14 & -0.77 & -1.59 & -3.74 & -4.30 & -3.94 & \\
\hline 1968 & 0.80 & 1.61 & 0.68 & -0.46 & -1.04 & -1.74 & -3.39 & -3.65 & -3.15 & -2.35 \\
\hline 1969 & 0.05 & 0.69 & -0.23 & -1.33 & -1.94 & -2.68 & -4.17 & -4.55 & -4.52 & -4.81 \\
\hline 1970 & 1.37 & 2.08 & 1.38 & 0.57 & 0.26 & -0.07 & -0.92 & -0.57 & 0.48 & 1.99 \\
\hline 1971 & 1.87 & 2.57 & 1.97 & 1.29 & 1.10 & 0.91 & 0.32 & 0.82 & 1.95 & 3.48 \\
\hline 1972 & 1.85 & 2.50 & 1.94 & 1.32 & 1.15 & 0.99 & 0.49 & 0.94 & 1.90 & 3.11 \\
\hline 1973 & 1.20 & 1.75 & 1.18 & 0.55 & 0.33 & 0.10 & -0.44 & -0.17 & 0.49 & 1.25 \\
\hline 1974 & 0.24 & 0.68 & 0.08 & -0.57 & -0.87 & -1.18 & -1.79 & -1.70 & -1.32 & -0.94 \\
\hline 1975 & 0.09 & 0.50 & -0.07 & -0.69 & -0.97 & -1.26 & -1.83 & -1.75 & -1.42 & -1.10 \\
\hline 1976 & 0.85 & 1.27 & 0.79 & 0.26 & 0.06 & -0.13 & -0.55 & -0.36 & 0.08 & 0.53 \\
\hline 1977 & 0.78 & 1.18 & 0.72 & 0.22 & 0.03 & -0.15 & -0.54 & -0.37 & 0.03 & 0.44 \\
\hline 1978 & 0.52 & 0.89 & 0.44 & -0.05 & -0.24 & -0.42 & -0.81 & -0.67 & -0.33 & 0.00 \\
\hline 1979 & -0.09 & 0.23 & -0.23 & -0.72 & -0.94 & -1.16 & -1.56 & -1.49 & -1.24 & -1.01 \\
\hline 1980 & -0.43 & -0.15 & -0.60 & -1.09 & -1.31 & -1.54 & -1.94 & -1.89 & -1.69 & -1.52 \\
\hline 1981 & -1.01 & -0.77 & -1.23 & -1.71 & -1.96 & -2.20 & -2.62 & -2.62 & -2.48 & -2.38 \\
\hline 1982 & 0.24 & 0.52 & 0.14 & -0.27 & -0.43 & -0.59 & -0.89 & -0.79 & -0.55 & -0.32 \\
\hline 1983 & 0.45 & 0.73 & 0.37 & 0.00 & -0.15 & -0.28 & -0.56 & -0.44 & -0.19 & 0.05 \\
\hline 1984 & 0.93 & 1.23 & 0.90 & 0.56 & 0.45 & 0.35 & 0.11 & 0.26 & 0.54 & 0.81 \\
\hline 1985 & 1.61 & 1.92 & 1.63 & 1.33 & 1.26 & 1.20 & 1.01 & 1.20 & 1.52 & 1.83 \\
\hline 1986 & 1.96 & 2.27 & 2.01 & 1.74 & 1.68 & 1.64 & 1.48 & 1.68 & 2.01 & 2.33 \\
\hline 1987 & 1.80 & 2.10 & 1.84 & 1.57 & 1.51 & 1.47 & 1.31 & 1.50 & 1.80 & 2.09 \\
\hline
\end{tabular}




\section{TABLE 5-10 (Continued)}

\begin{tabular}{|c|c|c|c|c|c|c|c|c|c|}
\hline $\begin{array}{l}\text { TO THE } \\
\text { END OF }\end{array}$ & $\begin{array}{l}\text { FROM } \\
1969\end{array}$ & $\begin{array}{l}\text { HE BEG } \\
1970\end{array}$ & $\underset{1971}{\text { JNING OF }}$ & 1972 & 1973 & 1974 & 1975 & 1976 & 1977 \\
\hline 1969 & -7.21 & & & & & & & & \\
\hline 1970 & 4.23 & 17.09 & & & & & & & \\
\hline 1971 & 5.50 & 12.49 & 8.07 & & & & & & \\
\hline 1972 & 4.52 & 8.75 & 4.81 & 1.64 & & & & & \\
\hline 1973 & 1.99 & 4.42 & 0.51 & -3.07 & -7.55 & & & & \\
\hline 1974 & -0.70 & 0.65 & -3.09 & -6.54 & -10.38 & -13.13 & & & \\
\hline 1975 & -0.92 & 0.17 & -2.91 & -5.47 & -7.73 & -7.82 & -2.19 & & \\
\hline 1976 & 0.90 & 2.11 & -0.19 & -1.77 & -2.60 & -0.89 & 5.86 & 14.57 & \\
\hline 1977 & 0.75 & 1.79 & -0.22 & -1.54 & -2.16 & -0.77 & 3.73 & 6.82 & -0.40 \\
\hline 1978 & 0.24 & 1.11 & -0.73 & -1.93 & -2.51 & -1.47 & 1.68 & 3.00 & -2.34 \\
\hline 1979 & -0.89 & -0.23 & -1.99 & -3.18 & -3.85 & -3.22 & -1.11 & -0.84 & -5.50 \\
\hline 1980 & -1.45 & -0.91 & -2.55 & -3.66 & -4.30 & -3.83 & -2.19 & -2.19 & -5.98 \\
\hline 1981 & -2.38 & -1.97 & -3.54 & -4.63 & -5.30 & -5.02 & -3.80 & -4.06 & -7.41 \\
\hline 1982 & -0.17 & 0.39 & -0.88 & -1.66 & -1.98 & -1.35 & 0.23 & 0.59 & -1.57 \\
\hline 1983 & 0.21 & 0.76 & -0.40 & -1.07 & -1.31 & -0.67 & 0.82 & 1.21 & -0.57 \\
\hline 1984 & 1.01 & 1.58 & 0.56 & 0.00 & -0.13 & 0.57 & 2.05 & 2.54 & 1.12 \\
\hline 1985 & 2.08 & 2.69 & 1.80 & 1.36 & 1.34 & 2.12 & 3.63 & 4.23 & 3.14 \\
\hline 1986 & 2.60 & 3.21 & 2.40 & 2.03 & 2.06 & 2.84 & 4.30 & 4.91 & 3.99 \\
\hline 1987 & 2.33 & 2.89 & 2.11 & 1.75 & 1.76 & 2.46 & 3.77 & 4.28 & 3.39 \\
\hline
\end{tabular}

TO THE FROM THE BEGINNING OF

$\begin{array}{lllllllllll}\text { END OF } & 1978 & 1979 & 1980 & 1981 & 1982 & 1983 & 1984 & 1985 & 1986 & 1987\end{array}$

$\begin{array}{rrrrrrrrrrr}1978 & -4.23 & & & & & & & & & \\ 1979 & -7.96 & -11.53 & & & & & & & \\ 1980 & -7.77 & -9.49 & -7.39 & & & & & & \\ 1981 & -9.08 & -10.64 & -10.19 & -12.90 & & & & & \\ 1982 & -1.81 & -1.19 & 2.52 & 7.87 & 33.60 & & & & \\ 1983 & -0.60 & 0.14 & 3.30 & 7.13 & 18.81 & 5.66 & & & \\ 1984 & 1.34 & 2.30 & 5.32 & 8.76 & 17.12 & 9.66 & 13.82 & & \\ 1985 & 3.59 & 4.76 & 7.76 & 11.07 & 18.04 & 13.26 & 17.27 & 20.81 & \\ 1986 & 4.48 & 5.63 & 8.34 & 11.21 & 16.78 & 12.92 & 15.44 & 16.26 & 11.88 & \\ 1987 & 3.78 & 4.71 & 6.94 & 9.16 & 13.34 & 9.67 & 10.70 & 9.68 & 4.50 & -2.39\end{array}$


TABLE 5-11

MUNICIPAL BONDS: TOTAL RETURNS RATES OF RETURN FOR VARIOUS HOLDING PERIODS FROM 1950 TO 1987

\begin{tabular}{|c|c|c|c|c|c|c|c|c|c|}
\hline $\begin{array}{l}\text { TO THE } \\
\text { END OF }\end{array}$ & $\begin{array}{l}\text { FROM } \\
1950\end{array}$ & $\underset{1951}{\text { THE BEG }}$ & $\begin{array}{l}\text { NING OF } \\
1952\end{array}$ & 1953 & 1954 & 1955 & 1956 & 1957 & 1958 \\
\hline 1950 & 3.41 & & & & & & & & \\
\hline $\begin{array}{l}1951 \\
1952\end{array}$ & $\begin{array}{l}-3.73 \\
-0.42\end{array}$ & $\begin{array}{r}-10.39 \\
-2.28\end{array}$ & 6.56 & & & & & & \\
\hline $\begin{array}{l}1952 \\
1953\end{array}$ & 1.15 & 0.40 & 6.27 & 5.99 & & & & & \\
\hline 1954 & 3.57 & 3.60 & 8.74 & 9.84 & 13.84 & & & & \\
\hline 1955 & 2.99 & 2.90 & 6.52 & 6.51 & 6.77 & 0.14 & & & \\
\hline 1956 & 0.85 & 0.42 & 2.74 & 1.80 & 0.45 & -5.65 & -11.10 & & \\
\hline 1957 & 1.90 & 1.68 & 3.85 & 3.31 & 2.66 & -0.82 & -1.30 & 9.58 & \\
\hline 1958 & 1.93 & 1.75 & 3.61 & 3.13 & 2.57 & -0.07 & -0.14 & 5.83 & 2.22 \\
\hline 1959 & 1.03 & 0.77 & 2.26 & 1.66 & 0.96 & -1.44 & -1.83 & 1.47 & -2.36 \\
\hline 1960 & 2.08 & 1.95 & 3.42 & 3.04 & 2.62 & 0.87 & 1.01 & 4.29 & 2.58 \\
\hline 1961 & 2.80 & 2.74 & 4.16 & 3.90 & 3.64 & 2.26 & 2.61 & 5.60 & 4.63 \\
\hline 1962 & 2.97 & 2.94 & 4.24 & 4.01 & 3.80 & 2.61 & 2.96 & 5.51 & 4.72 \\
\hline 1963 & 3.10 & 3.08 & 4.29 & 4.08 & 3.89 & 2.84 & 3.19 & 5.41 & 4.73 \\
\hline 1964 & 3.35 & 3.35 & 4.49 & 4.32 & 4.17 & 3.25 & 3.60 & 5.60 & 5.04 \\
\hline 1965 & 3.19 & 3.18 & 4.22 & 4.04 & 3.88 & 3.02 & 3.32 & 5.06 & 4.50 \\
\hline 1966 & 2.95 & 2.92 & 3.88 & 3.69 & 3.52 & 2.70 & 2.94 & 4.45 & 3.90 \\
\hline 1967 & 2.72 & 2.68 & 3.56 & 3.36 & 3.18 & 2.40 & 2.59 & 3.94 & 3.39 \\
\hline 1968 & 2.70 & 2.66 & 3.48 & 3.29 & 3.11 & 2.39 & 2.56 & 3.79 & 3.28 \\
\hline 1969 & 2.33 & 2.27 & 3.02 & 2.82 & 2.63 & 1.92 & 2.05 & 3.13 & 2.61 \\
\hline 1970 & 3.07 & 3.05 & 3.81 & 3.66 & 3.52 & 2.91 & 3.10 & 4.20 & 3.79 \\
\hline 1971 & 3.68 & 3.70 & 4.46 & 4.35 & 4.26 & 3.72 & 3.95 & 5.03 & 4.72 \\
\hline 1972 & 3.76 & 3.78 & 4.50 & 4.40 & 4.32 & 3.81 & 4.03 & 5.06 & 4.77 \\
\hline 1973 & 3.71 & 3.72 & 4.41 & 4.31 & 4.23 & 3.74 & 3.95 & 4.91 & 4.62 \\
\hline 1974 & 3.38 & 3.38 & 4.02 & 3.91 & 3.81 & 3.33 & 3.50 & 4.38 & 4.08 \\
\hline 1975 & 3.52 & 3.52 & 4.15 & 4.04 & 3.96 & 3.51 & 3.68 & 4.52 & 4.25 \\
\hline 1976 & 4.25 & 4.28 & 4.91 & 4.84 & 4.79 & 4.40 & 4.61 & 5.46 & $\begin{array}{l}4.20 \\
5.25\end{array}$ \\
\hline 1977 & 4.39 & 4.43 & 5.05 & 4.99 & 4.95 & 4.57 & 4.78 & 5.60 & 5.41 \\
\hline 1978 & 4.42 & 4.45 & 5.05 & 4.99 & 4.95 & 4.59 & 4.79 & 5.58 & $\begin{array}{l}0.41 \\
5.39\end{array}$ \\
\hline 1979 & 4.19 & 4.21 & 4.78 & 4.71 & 4.66 & 4.31 & 4.49 & 5.23 & $\begin{array}{l}0.07 \\
5.03\end{array}$ \\
\hline 1980 & 4.10 & 4.13 & 4.67 & 4.60 & 4.55 & 4.21 & 4.37 & 5.07 & $\begin{array}{l}5.03 \\
4.88\end{array}$ \\
\hline 1981 & 3.99 & 4.01 & 4.52 & 4.45 & 4.40 & 4.07 & 4.22 & 4.88 & 4.69 \\
\hline 1982 & 5.05 & 5.10 & 5.64 & 5.61 & 5.60 & 5.31 & 5.51 & 6.21 & 6.07 \\
\hline 1983 & 5.21 & 5.27 & 5.80 & 5.77 & 5.77 & 5.50 & 5.70 & 6.38 & 6.25 \\
\hline 1984 & 5.58 & 5.65 & 6.18 & 6.16 & 6.17 & 5.92 & 6.13 & 6.80 & 6.70 \\
\hline 1985 & 6.06 & 6.14 & 6.67 & 6.67 & 6.69 & 6.47 & 6.69 & 7.36 & 7.28 \\
\hline 1986 & 6.33 & 6.42 & 6.94 & 6.95 & 6.98 & 6.77 & 6.99 & 7.66 & 7.59 \\
\hline 1987 & 6.23 & 6.30 & 6.81 & 6.81 & 6.84 & 6.63 & 6.84 & 7.48 & 7.41 \\
\hline
\end{tabular}




\section{TABLE 5-11 (Continued)}

\begin{tabular}{|c|c|c|c|c|c|c|c|c|c|c|}
\hline TO THE & FROM & THE B & INNI & & & & & & & \\
\hline END OF & 1959 & 1960 & 1961 & 1962 & 1963 & 1964 & 1965 & 1966 & 1967 & 1968 \\
\hline 1959 & -6.73 & & & & & & & & & \\
\hline 1960 & 2.76 & 13.22 & & & & & & & & \\
\hline 1961 & 5.44 & 12.11 & 11.01 & & & & & & & \\
\hline 1962 & 5.35 & 9.72 & 8.01 & 5.08 & & & & & & \\
\hline 1963 & 5.24 & 8.46 & 6.92 & 4.93 & 4.78 & & & & & \\
\hline 1964 & 5.52 & 8.16 & 6.93 & 5.60 & 5.86 & 6.95 & & & & \\
\hline 1965 & 4.83 & 6.90 & 5.67 & 4.38 & 4.15 & 3.83 & 0.81 & & & \\
\hline 1966 & 4.11 & 5.76 & 4.57 & 3.32 & 2.89 & 2.26 & 0.00 & -0.81 & & \\
\hline 1967 & 3.52 & 4.88 & 3.73 & 2.57 & 2.07 & 1.41 & -0.37 & -0.96 & -1.12 & \\
\hline 1968 & 3.39 & 4.58 & 3.54 & 2.52 & 2.10 & 1.57 & 0.26 & 0.08 & 0.53 & 2.21 \\
\hline 1969 & 2.65 & 3.64 & 2.63 & 1.62 & 1.14 & 0.54 & -0.69 & -1.06 & -1.15 & -1.16 \\
\hline 1970 & 3.92 & 4.95 & 4.16 & 3.42 & 3.22 & 3.00 & 2.35 & 2.66 & 3.55 & 5.15 \\
\hline 1971 & 4.91 & 5.95 & 5.31 & 4.75 & 4.72 & 4.71 & 4.39 & 5.00 & 6.21 & 8.12 \\
\hline 1972 & 4.95 & 5.91 & 5.32 & 4.82 & 4.79 & 4.79 & 4.53 & 5.07 & 6.08 & 7.58 \\
\hline 1973 & 4.79 & 5.66 & 5.10 & 4.62 & 4.58 & 4.56 & 4.30 & 4.74 & 5.56 & 6.71 \\
\hline 1974 & 4.20 & 4.97 & 4.41 & 3.92 & 3.82 & 3.73 & 3.42 & 3.71 & 4.29 & 5.09 \\
\hline 1975 & 4.37 & 5.10 & 4.58 & 4.14 & 4.07 & 4.01 & 3.74 & 4.04 & 4.60 & 5.33 \\
\hline 1976 & 5.42 & 6.18 & 5.76 & 5.42 & 5.44 & 5.49 & 5.37 & 5.80 & 6.48 & 7.36 \\
\hline 1977 & 5.58 & 6.31 & 5.92 & 5.61 & 5.64 & 5.70 & 5.61 & 6.02 & 6.66 & 7.47 \\
\hline 1978 & 5.55 & 6.24 & 5.87 & 5.57 & 5.60 & 5.66 & 5.56 & 5.94 & 6.52 & 7.25 \\
\hline 1979 & 5.17 & 5.80 & 5.42 & 5.12 & 5.12 & 5.15 & 5.03 & 5.34 & 5.82 & 6.42 \\
\hline 1980 & 5.00 & 5.60 & 5.23 & 4.93 & 4.92 & 4.93 & 4.81 & 5.08 & 5.51 & 6.04 \\
\hline 1981 & 4.80 & 5.36 & 5.00 & 4.71 & 4.69 & 4.68 & 4.55 & 4.79 & 5.17 & 5.64 \\
\hline 1982 & 6.24 & 6.84 & 6.56 & 6.35 & 6.42 & 6.50 & 6.48 & 6.82 & 7.32 & 7.90 \\
\hline 1983 & 6.42 & 7.01 & 6.74 & 6.55 & 6.62 & 6.72 & 6.70 & 7.04 & 7.52 & 8.09 \\
\hline 1984 & 6.88 & 7.46 & 7.23 & 7.07 & 7.16 & 7.27 & 7.29 & 7.64 & 8.13 & 8.70 \\
\hline 1985 & 7.48 & 8.06 & 7.86 & 7.73 & 7.85 & 7.99 & 8.04 & 8.42 & 8.93 & 9.51 \\
\hline 1986 & 7.79 & 8.37 & 8.18 & 8.07 & 8.20 & 8.35 & 8.41 & 8.79 & 9.29 & 9.87 \\
\hline 1987 & 7.59 & 8.14 & 7.96 & 7.84 & 7.96 & 8.09 & 8.14 & 8.49 & 8.95 & 9.48 \\
\hline
\end{tabular}




\section{TABLE 5-11 (Continued)}

\begin{tabular}{|c|c|c|c|c|c|c|c|c|c|}
\hline $\begin{array}{l}\text { TO THE } \\
\text { END OF }\end{array}$ & $\begin{array}{l}\text { FROM } \\
1969\end{array}$ & $\begin{array}{c}\text { HE BEG } \\
1970\end{array}$ & $\begin{array}{l}\text { JNING OF } \\
1971\end{array}$ & 1972 & 1973 & 1974 & 1975 & 1976 & 1977 \\
\hline 1969 & -4.42 & & & & & & & & \\
\hline 1970 & 6.66 & 19.02 & & & & & & & \\
\hline 1971 & 10.17 & 18.27 & 17.53 & & & & & & \\
\hline 1972 & 8.97 & 13.83 & 11.32 & 5.45 & & & & & \\
\hline 1973 & 7.64 & 10.89 & 8.30 & 3.96 & 2.49 & & & & \\
\hline 1974 & 5.57 & 7.70 & 5.04 & 1.18 & -0.89 & -4.17 & & & \\
\hline 1975 & 5.79 & 7.59 & 5.44 & 2.62 & 1.69 & 1.29 & 7.07 & & \\
\hline 1976 & 8.02 & 9.93 & 8.48 & 6.75 & 7.08 & 8.66 & 15.70 & 25.03 & \\
\hline 1977 & 8.07 & 9.74 & 8.48 & 7.04 & 7.36 & 8.61 & 13.24 & 16.46 & 8.48 \\
\hline 1978 & 7.76 & 9.21 & 8.04 & 6.75 & 6.97 & 7.89 & 11.13 & 12.52 & 6.74 \\
\hline 1979 & 6.82 & 8.01 & 6.85 & 5.59 & 5.61 & 6.13 & 8.32 & 8.64 & 3.67 \\
\hline 1980 & 6.37 & 7.41 & 6.31 & 5.13 & 5.09 & 5.47 & 7.17 & 7.19 & 3.14 \\
\hline 1981 & 5.91 & 6.81 & 5.77 & 4.66 & 4.57 & 4.84 & 6.19 & 6.04 & 2.61 \\
\hline 1982 & 8.32 & 9.37 & 8.60 & 7.82 & 8.07 & 8.70 & 10.43 & 10.92 & 8.72 \\
\hline 1983 & 8.49 & 9.48 & 8.77 & 8.08 & 8.32 & 8.92 & 10.48 & 10.91 & 9.03 \\
\hline 1984 & 9.12 & 10.09 & 9.47 & 8.88 & 9.17 & 9.80 & 11.30 & 11.78 & 10.23 \\
\hline 1985 & 9.96 & 10.93 & 10.41 & 9.91 & 10.27 & 10.94 & 12.43 & 12.98 & 11.71 \\
\hline 1986 & 10.31 & 11.25 & 10.78 & 10.34 & 10.70 & 11.36 & 12.76 & 13.29 & 12.18 \\
\hline 1987 & 9.88 & 10.73 & 10.26 & 9.82 & 10.12 & 10.69 & 11.92 & 12.33 & 11.24 \\
\hline
\end{tabular}

TO THE FROM THE BEGINNING OF

$\begin{array}{lrrrrrrrrrr}\text { END OF } & \mathbf{1 9 7 8} & \mathbf{1 9 7 9} & \mathbf{1 9 8 0} & \mathbf{1 9 8 1} & \mathbf{1 9 8 2} & \mathbf{1 9 8 3} & \mathbf{1 9 8 4} & \mathbf{1 9 8 5} & \mathbf{1 9 8 6} & \mathbf{1 9 8 7} \\ 1978 & 5.02 & & & & & & & & & \\ 1979 & 1.34 & -2.21 & & & & & & & & \\ 1980 & 1.42 & -0.33 & 1.58 & & & & & & & \\ 1981 & 1.19 & -0.06 & 1.04 & 0.50 & & & & & & \\ 1982 & 8.77 & 9.73 & 14.03 & 20.82 & 45.24 & & & & & \\ 1983 & 9.12 & 9.96 & 13.23 & 17.41 & 26.90 & 10.87 & & & & \\ 1984 & 10.48 & 11.42 & 14.36 & 17.80 & 24.21 & 14.86 & 18.99 & & & \\ 1985 & 12.12 & 13.17 & 15.96 & 19.08 & 24.23 & 17.93 & 21.63 & 24.32 & & \\ 1986 & 12.60 & 13.58 & 16.04 & 18.64 & 22.65 & 17.57 & 19.89 & 20.34 & 16.50 & \\ 1987 & 11.53 & 12.27 & 14.23 & 16.16 & 19.00 & 14.35 & 15.23 & 14.00 & 9.17 & 2.31\end{array}$


TABLE 5-12

MUNICIPAL BONDS: REAL RETURNS RATES OF RETURN FOR VARIOUS HOLDING PERIODS FROM 1950 TO 1987

\begin{tabular}{|c|c|c|c|c|c|c|c|c|c|}
\hline $\begin{array}{l}\text { TO THE } \\
\text { END OF }\end{array}$ & $\begin{array}{l}\text { FROM } \\
1950\end{array}$ & $\begin{array}{c}\text { THE BEG } \\
1951\end{array}$ & $\begin{array}{l}\text { NING OF } \\
1952\end{array}$ & 1953 & 1954 & 1955 & 1956 & 1957 & 1958 \\
\hline 1950 & -2.53 & & & & & & & & \\
\hline 1951 & -11.18 & -19.07 & & & & & & & \\
\hline 1952 & -5.07 & -6.32 & 8.43 & & & & & & \\
\hline 1953 & -2.42 & -2.39 & 7.20 & 5.99 & & & & & \\
\hline 1954 & 0.56 & 1.35 & 9.24 & 9.65 & 13.44 & & & & \\
\hline 1955 & 0.43 & 1.04 & 6.80 & 6.26 & 6.40 & -0.21 & & & \\
\hline 1956 & -1.74 & -1.60 & 2.32 & 0.84 & -0.82 & -7.26 & -13.81 & & \\
\hline 1957 & -0.64 & -0.37 & 3.15 & 2.12 & 1.18 & -2.61 & -3.79 & 7.39 & \\
\hline 1958 & -0.62 & -0.37 & 2.63 & 1.69 & 0.85 & -2.07 & -2.68 & 3.41 & -0.43 \\
\hline 1959 & -1.37 & -1.24 & 1.25 & 0.26 & -0.66 & -3.27 & -4.02 & -0.51 & -4.25 \\
\hline 1960 & -0.24 & -0.01 & 2.37 & 1.63 & 1.03 & -0.91 & -1.05 & 2.43 & 0.83 \\
\hline 1961 & 0.62 & 0.92 & 3.17 & 2.60 & 2.18 & 0.67 & 0.82 & 4.03 & 3.20 \\
\hline 1962 & 0.84 & 1.13 & 3.19 & 2.68 & 2.32 & 1.01 & 1.19 & 3.93 & 3.25 \\
\hline 1963 & 0.98 & 1.26 & 3.17 & 2.70 & 2.38 & 1.22 & 1.40 & 3.78 & 3.19 \\
\hline 1964 & 1.25 & 1.52 & 3.31 & 2.89 & 2.62 & 1.59 & 1.80 & 3.93 & 3.45 \\
\hline 1965 & 1.04 & 1.28 & 2.91 & 2.50 & 2.21 & 1.25 & 1.40 & 3.24 & 2.74 \\
\hline 1966 & 0.72 & 0.93 & 2.43 & 2.01 & 1.71 & 0.79 & 0.88 & 2.48 & 1.95 \\
\hline 1967 & 0.39 & 0.56 & 1.94 & 1.52 & 1.21 & 0.32 & 0.37 & 1.77 & 1.22 \\
\hline 1968 & 0.28 & 0.43 & 1.72 & 1.31 & 1.01 & 0.17 & 0.20 & 1.47 & 0.95 \\
\hline 1969 & -0.19 & -0.07 & 1.11 & 0.70 & 0.37 & -0.44 & -0.46 & 0.65 & 0.11 \\
\hline 1970 & 0.58 & 0.74 & 1.90 & 1.55 & 1.30 & 0.58 & 0.64 & 1.76 & 1.34 \\
\hline 1971 & 1.07 & 1.25 & 2.39 & 2.08 & 1.87 & 1.23 & 1.32 & 2.41 & 2.07 \\
\hline 1972 & 1.04 & 1.21 & 2.29 & 1.99 & 1.79 & 1.18 & 1.26 & 2.28 & 1.95 \\
\hline 1973 & 0.73 & 0.87 & 1.89 & 1.59 & 1.37 & 0.77 & 0.83 & 1.76 & 1.42 \\
\hline 1974 & 0.06 & 0.17 & 1.10 & 0.78 & 0.54 & -0.06 & -0.05 & 0.77 & 0.39 \\
\hline 1975 & -0.03 & 0.07 & 0.96 & 0.65 & 0.41 & -0.17 & -0.17 & 0.61 & 0.25 \\
\hline 1976 & 0.59 & 0.71 & 1.60 & 1.32 & 1.12 & 0.60 & 0.63 & 1.42 & 1.11 \\
\hline 1977 & 0.54 & 0.65 & 1.50 & 1.23 & 1.04 & 0.53 & 0.56 & 1.31 & 1.01 \\
\hline 1978 & 0.41 & 0.52 & 1.33 & 1.06 & 0.87 & 0.38 & 0.40 & 1.10 & 0.81 \\
\hline 1979 & 0.01 & 0.10 & 0.86 & 0.59 & 0.39 & -0.10 & -0.10 & 0.55 & 0.25 \\
\hline 1980 & -0.28 & -0.21 & 0.52 & 0.24 & 0.04 & -0.44 & -0.45 & 0.15 & -0.16 \\
\hline 1981 & -0.61 & -0.55 & 0.13 & -0.14 & -0.35 & -0.83 & -0.85 & -0.30 & -0.60 \\
\hline 1982 & 0.27 & 0.35 & 1.05 & 0.82 & 0.64 & 0.21 & 0.23 & 0.81 & 0.56 \\
\hline 1983 & 0.43 & 0.52 & 1.21 & 0.98 & 0.82 & 0.41 & 0.43 & 1.00 & 0.76 \\
\hline 1984 & 0.81 & 0.91 & 1.59 & 1.38 & 1.24 & 0.85 & 0.89 & 1.46 & 1.25 \\
\hline 1985 & 1.28 & 1.39 & 2.07 & 1.88 & 1.75 & 1.40 & 1.45 & 2.02 & 1.84 \\
\hline 1986 & 1.55 & 1.67 & 2.33 & 2.16 & 2.05 & 1.71 & 1.77 & 2.34 & 2.17 \\
\hline 1987 & 1.46 & 1.57 & 2.22 & 2.05 & 1.93 & 1.60 & 1.66 & 2.20 & 2.03 \\
\hline
\end{tabular}


TABLE 5-12 (Continued)

\begin{tabular}{|c|c|c|c|c|c|c|c|c|c|c|}
\hline \multirow{2}{*}{$\begin{array}{l}\text { TO THE } \\
\text { END OF }\end{array}$} & \multicolumn{10}{|c|}{ FROM THE BEGINNING OF } \\
\hline & 1959 & 1960 & 1961 & 1962 & 1963 & 1964 & 1965 & 1966 & 1967 & 1968 \\
\hline 1959 & -7.92 & & & & & & & & & \\
\hline 1960 & 1.46 & 11.79 & & & & & & & & \\
\hline 1961 & 4.44 & 11.23 & 10.67 & & & & & & & \\
\hline 1962 & 4.19 & 8.57 & 7.00 & 3.45 & & & & & & \\
\hline 1963 & 3.93 & 7.12 & 5.60 & 3.16 & 2.87 & & & & & \\
\hline 1964 & 4.11 & 6.70 & 5.46 & 3.78 & 3.94 & 5.03 & & & & \\
\hline 1965 & 3.20 & 5.18 & 3.90 & 2.28 & 1.89 & 1.40 & -2.11 & & & \\
\hline 1966 & 2.25 & 3.79 & 2.52 & 0.96 & 0.34 & -0.48 & -3.13 & -4.14 & & \\
\hline 1967 & 1.41 & 2.64 & 1.39 & -0.08 & -0.77 & -1.66 & -3.79 & -4.62 & -5.10 & \\
\hline 1968 & 1.09 & 2.14 & 0.99 & -0.32 & -0.93 & -1.68 & -3.29 & -3.68 & -3.44 & -1.75 \\
\hline 1969 & 0.16 & 1.00 & -0.13 & -1.40 & -2.08 & -2.88 & -4.39 & -4.95 & -5.22 & -5.27 \\
\hline 1970 & 1.48 & 2.38 & 1.49 & 0.52 & 0.16 & -0.23 & -1.08 & -0.87 & -0.03 & 1.72 \\
\hline 1971 & 2.26 & 3.16 & 2.41 & 1.62 & 1.41 & 1.23 & 0.70 & 1.18 & 2.28 & 4.21 \\
\hline 1972 & 2.12 & 2.94 & 2.23 & 1.50 & 1.31 & 1.13 & 0.66 & 1.06 & 1.95 & 3.42 \\
\hline 1973 & 1.54 & 2.26 & 1.56 & 0.83 & 0.60 & 0.37 & -0.13 & 0.12 & 0.74 & 1.75 \\
\hline 1974 & 0.45 & 1.03 & 0.30 & -0.45 & -0.77 & -1.10 & -1.69 & -1.64 & -1.33 & -0.78 \\
\hline 1975 & 0.29 & 0.82 & 0.13 & -0.58 & -0.89 & -1.19 & -1.74 & -1.70 & -1.43 & -0.96 \\
\hline 1976 & 1.20 & 1.76 & 1.17 & 0.56 & 0.36 & 0.17 & -0.23 & -0.05 & 0.36 & 0.99 \\
\hline 1977 & 1.09 & 1.61 & 1.04 & 0.47 & 0.27 & 0.09 & -0.28 & -0.12 & 0.25 & 0.80 \\
\hline 1978 & 0.87 & 1.36 & 0.81 & 0.26 & 0.06 & -0.12 & -0.48 & -0.35 & -0.03 & 0.44 \\
\hline 1979 & 0.28 & 0.71 & 0.15 & -0.40 & -0.62 & -0.84 & -1.22 & -1.15 & -0.92 & -0.56 \\
\hline 1980 & -0.15 & 0.24 & -0.31 & -0.85 & -1.09 & -1.31 & -1.70 & -1.67 & -1.49 & -1.21 \\
\hline 1981 & -0.61 & -0.27 & -0.81 & -1.35 & -1.60 & -1.84 & -2.23 & -2.24 & -2.11 & -1.89 \\
\hline 1982 & 0.60 & 0.99 & 0.52 & 0.06 & -0.11 & -0.26 & -0.55 & -0.45 & -0.22 & 0.12 \\
\hline 1983 & 0.81 & 1.19 & 0.76 & 0.33 & 0.18 & 0.05 & -0.21 & -0.10 & 0.14 & 0.48 \\
\hline 1984 & 1.31 & 1.70 & 1.30 & 0.91 & 0.80 & 0.70 & 0.49 & 0.63 & 0.90 & 1.26 \\
\hline 1985 & 1.92 & 2.32 & 1.96 & 1.61 & 1.53 & 1.47 & 1.31 & 1.48 & 1.78 & 2.18 \\
\hline 1986 & 2.26 & 2.66 & 2.32 & 2.00 & 1.94 & 1.90 & 1.76 & 1.95 & 2.26 & 2.67 \\
\hline 1987 & 2.12 & 2.50 & 2.17 & 1.85 & 1.79 & 1.75 & 1.61 & 1.78 & 2.07 & 2.44 \\
\hline
\end{tabular}


TABLE 5-12 (Continued)

\begin{tabular}{|c|c|c|c|c|c|c|c|c|c|}
\hline $\begin{array}{l}\text { TO THE } \\
\text { END OF }\end{array}$ & $\begin{array}{l}\text { FROM } \\
1969\end{array}$ & $\begin{array}{c}\text { HE BEC } \\
1970\end{array}$ & $\begin{array}{l}1971 \\
\text { ING OF }\end{array}$ & 1972 & 1973 & 1974 & 1975 & 1976 & 1977 \\
\hline 1969 & -8.67 & & & & & & & & \\
\hline 1970 & 3.50 & 17.29 & & & & & & & \\
\hline 1971 & 6.28 & 14.65 & 12.07 & & & & & & \\
\hline 1972 & 4.76 & 9.66 & 6.04 & 0.33 & & & & & \\
\hline 1973 & 2.47 & 5.46 & 1.79 & -2.99 & -6.20 & & & & \\
\hline 1974 & -0.61 & 1.08 & -2.61 & -7.06 & -10.54 & -14.68 & & & \\
\hline 1975 & -0.85 & 0.52 & -2.53 & -5.88 & -7.86 & -8.68 & -2.25 & & \\
\hline 1976 & 1.34 & 2.86 & 0.63 & -1.51 & -1.97 & -0.52 & 7.43 & 18.06 & \\
\hline 1977 & 1.09 & 2.38 & 0.41 & -1.41 & -1.76 & -0.61 & 4.58 & 8.17 & -0.89 \\
\hline 1978 & 0.66 & 1.76 & -0.03 & -1.65 & -1.98 & -1.11 & 2.61 & 4.28 & -1.99 \\
\hline 1979 & -0.45 & 0.41 & -1.31 & -2.86 & -3.31 & -2.82 & -0.26 & 0.25 & -5.07 \\
\hline 1980 & -1.16 & -0.45 & -2.07 & -3.52 & $\begin{array}{l}-3.99 \\
\end{array}$ & -3.67 & -1.71 & -1.60 & -5.98 \\
\hline 1981 & -1.90 & -1.31 & -2.85 & -4.23 & -4.72 & -4.53 & -2.99 & -3.11 & -6.87 \\
\hline 1982 & 0.25 & 0.97 & -0.28 & -1.33 & -1.50 & -0.96 & 0.91 & 1.36 & -1.18 \\
\hline 1983 & 0.63 & 1.33 & 0.19 & -0.74 & -0.83 & -0.28 & 1.47 & 1.94 & -0.18 \\
\hline 1984 & 1.45 & 2.17 & 1.17 & 0.37 & 0.38 & 1.00 & 2.71 & 3.28 & 1.57 \\
\hline 1985 & 2.42 & 3.15 & 2.27 & 1.61 & 1.71 & 2.40 & 4.11 & 4.77 & 3.39 \\
\hline 1986 & 2.92 & 3.65 & 2.85 & 2.26 & 2.40 & 3.09 & 4.73 & 5.39 & 4.20 \\
\hline 1987 & 2.67 & 3.34 & 2.57 & 2.00 & 2.12 & 2.74 & 4.22 & 4.77 & 3.64 \\
\hline
\end{tabular}

TO THE FROM THE BEGINNING OF

$\begin{array}{lllllllllll}\text { END OF } & 1978 & 1979 & 1980 & 1981 & 1982 & 1983 & 1984 & 1985 & 1986 & 1987\end{array}$

$\begin{array}{rrrrrrrrrrr}1978 & -3.08 & & & & & & & & & \\ 1979 & -7.09 & -10.94 & & & & & & & \\ 1980 & -7.61 & -9.80 & -8.64 & & & & & & \\ 1981 & -8.30 & -9.98 & -9.50 & -10.34 & & & & & \\ 1982 & -1.24 & -0.77 & 2.87 & 9.17 & 32.92 & & & & \\ 1983 & -0.06 & 0.56 & 3.66 & 8.12 & 18.73 & 6.05 & & & \\ 1984 & 1.93 & 2.79 & 5.78 & 9.72 & 17.36 & 10.28 & 14.68 & & \\ 1985 & 3.93 & 4.98 & 7.89 & 11.54 & 17.80 & 13.16 & 16.88 & 19.13 & \\ 1986 & 4.78 & 5.81 & 8.45 & 11.59 & 16.59 & 12.83 & 15.18 & 15.43 & 11.84 & \\ 1987 & 4.11 & 4.94 & 7.11 & 9.58 & 13.30 & 9.74 & 10.68 & 9.38 & 4.81 & -1.77\end{array}$


TABLE 5-13

INDUSTRIAL BONDS: TOTAL RETURNS RATES OF RETURN FOR VARIOUS HOLDING PERIODS FROM 1950 TO 1987

\begin{tabular}{|c|c|c|c|c|c|c|c|c|c|}
\hline $\begin{array}{l}\text { TO THE } \\
\text { END OF }\end{array}$ & $\begin{array}{l}\text { FROM } \\
1950\end{array}$ & $\underset{1951}{\text { HE BEGI }}$ & $\begin{array}{l}\text { NING OF } \\
1952\end{array}$ & 1953 & 1954 & 1955 & 1956 & 1957 & 1958 \\
\hline 1950 & 2.67 & & & & & & & & \\
\hline $\begin{array}{l}1951 \\
1952\end{array}$ & $\begin{array}{r}-1.98 \\
0.11\end{array}$ & $\begin{array}{l}-6.43 \\
-1.15\end{array}$ & 4.43 & & & & & & \\
\hline 1953 & 1.07 & $\begin{array}{r}-1.15 \\
0.54\end{array}$ & $\begin{array}{l}4.43 \\
4.21\end{array}$ & 4.00 & & & & & \\
\hline 1954 & 2.86 & 2.90 & 6.21 & 7.12 & 10.33 & & & & \\
\hline 1955 & 2.74 & 2.76 & 5.19 & 5.44 & 6.17 & 2.18 & & & \\
\hline 1956 & 1.20 & 0.95 & 2.50 & 2.02 & 1.37 & -2.83 & -7.60 & & \\
\hline 1957 & 1.98 & 1.88 & 3.33 & 3.11 & 2.89 & 0.53 & -0.28 & 7.61 & \\
\hline 1958 & 2.09 & 2.02 & 3.28 & 3.09 & 2.91 & 1.14 & 0.80 & 5.28 & 3.00 \\
\hline 1959 & 1.43 & 1.30 & 2.30 & 2.00 & 1.68 & 0.03 & -0.50 & 1.98 & -0.72 \\
\hline 1960 & 2.35 & 2.31 & 3.33 & 3.20 & 3.08 & 1.92 & 1.87 & 4.39 & 3.34 \\
\hline 1961 & 2.88 & 2.90 & 3.88 & 3.82 & 3.80 & 2.90 & 3.02 & 5.28 & 4.71 \\
\hline 1962 & 3.04 & 3.07 & 3.98 & 3.93 & 3.92 & 3.15 & 3.29 & 5.22 & 4.75 \\
\hline 1963 & 3.20 & 3.24 & 4.09 & 4.06 & 4.07 & 3.39 & 3.55 & 5.25 & 4.86 \\
\hline 1964 & 3.30 & 3.35 & 4.14 & 4.12 & 4.13 & 3.53 & 3.68 & 5.18 & 4.84 \\
\hline 1965 & 3.05 & 3.08 & 3.79 & 3.74 & 3.72 & 3.14 & 3.24 & 4.52 & 4.14 \\
\hline 1966 & 2.78 & 2.79 & 3.43 & 3.36 & 3.31 & 2.75 & 2.80 & 3.90 & 3.50 \\
\hline 1967 & 2.60 & 2.60 & 3.19 & 3.11 & 3.05 & 2.51 & 2.53 & 3.51 & 3.11 \\
\hline 1968 & 2.59 & 2.59 & 3.15 & 3.07 & 3.00 & 2.50 & 2.52 & 3.42 & 3.04 \\
\hline 1969 & 2.41 & 2.39 & 2.91 & 2.82 & 2.75 & 2.26 & 2.27 & 3.07 & 2.70 \\
\hline 1970 & 2.93 & 2.95 & 3.47 & 3.41 & 3.38 & 2.96 & 3.01 & 3.81 & 3.53 \\
\hline 1971 & 3.43 & 3.47 & 3.99 & 3.96 & 3.96 & 3.60 & 3.69 & 4.49 & 4.27 \\
\hline 1972 & 3.69 & 3.74 & 4.25 & 4.24 & 4.25 & 3.92 & 4.02 & 4.80 & 4.61 \\
\hline 1973 & 3.63 & 3.68 & 4.16 & 4.15 & 4.16 & 3.84 & 3.93 & 4.66 & 4.47 \\
\hline 1974 & 3.24 & 3.26 & 3.70 & 3.67 & 3.66 & 3.33 & 3.39 & 4.04 & 3.84 \\
\hline 1975 & 3.43 & 3.46 & 3.89 & 3.87 & 3.86 & 3.57 & 3.64 & 4.26 & 4.08 \\
\hline 1976 & 4.10 & 4.16 & 4.61 & 4.62 & 4.64 & 4.39 & 4.50 & 5.14 & 5.01 \\
\hline 1977 & 4.33 & 4.39 & 4.83 & 4.85 & 4.88 & 4.65 & 4.77 & 5.39 & 5.29 \\
\hline 1978 & 4.36 & 4.42 & 4.84 & 4.86 & 4.89 & 4.67 & 4.78 & 5.38 & 5.28 \\
\hline 1979 & 4.16 & 4.21 & 4.61 & 4.61 & 4.64 & 4.42 & 4.51 & 5.07 & 4.96 \\
\hline 1980 & 4.12 & 4.16 & 4.55 & 4.55 & 4.58 & 4.36 & 4.45 & 4.98 & 4.87 \\
\hline 1981 & 3.96 & 4.00 & 4.37 & 4.37 & 4.38 & 4.16 & 4.24 & 4.75 & 4.63 \\
\hline 1982 & 4.98 & 5.05 & 5.44 & 5.48 & 5.53 & 5.36 & 5.48 & 6.02 & 5.95 \\
\hline 1983 & 5.23 & 5.31 & 5.70 & 5.74 & 5.80 & 5.64 & 5.77 & 6.30 & 6.25 \\
\hline 1984 & 5.60 & 5.68 & 6.07 & 6.12 & 6.19 & 6.06 & 6.20 & 6.72 & 6.69 \\
\hline 1985 & 6.07 & 6.17 & 6.57 & 6.63 & 6.72 & 6.60 & 6.75 & 7.29 & 7.27 \\
\hline 1986 & 6.22 & 6.32 & 6.71 & 6.78 & 6.86 & 6.75 & 6.91 & 7.43 & 7.42 \\
\hline 1987 & 6.22 & 6.32 & 6.69 & 6.76 & 6.84 & 6.74 & 6.88 & 7.39 & 7.38 \\
\hline
\end{tabular}


TABLE 5-13 (Continued)

\begin{tabular}{|c|c|c|c|c|c|c|c|c|c|c|}
\hline TO THE & FROM & THE B & INNII & & & & & & & \\
\hline END OF & & 1960 & 1961 & 1962 & 1963 & 1964 & 1965 & 1966 & 1967 & 1968 \\
\hline 1959 & -4.30 & & & & & & & & & \\
\hline 1960 & 3.51 & 11.96 & & & & & & & & \\
\hline 1961 & 5.29 & 10.43 & 8.93 & & & & & & & \\
\hline 1962 & 5.20 & 8.57 & 6.91 & 4.93 & & & & & & \\
\hline 1963 & 5.23 & 7.76 & 6.40 & 5.15 & 5.38 & & & & & \\
\hline 1964 & 5.15 & 7.15 & 5.98 & 5.01 & 5.05 & 4.73 & & & & \\
\hline 1965 & 4.31 & 5.81 & 4.63 & 3.58 & 3.13 & 2.02 & -0.62 & & & \\
\hline 1966 & 3.56 & 4.74 & 3.58 & 2.54 & 1.95 & 0.83 & -1.06 & -1.50 & & \\
\hline 1967 & 3.12 & 4.08 & 3.01 & 2.05 & 1.48 & 0.53 & -0.83 & -0.93 & -0.37 & \\
\hline 1968 & 3.05 & 3.90 & 2.93 & 2.10 & 1.64 & 0.91 & -0.03 & 0.17 & 1.02 & 2.42 \\
\hline 1969 & 2.67 & 3.39 & 2.48 & 1.71 & 1.25 & 0.58 & -0.23 & -0.13 & 0.33 & 0.68 \\
\hline 1970 & 3.57 & 4.32 & 3.58 & 3.01 & 2.77 & 2.40 & 2.02 & 2.55 & 3.59 & 4.94 \\
\hline 1971 & 4.37 & 5.12 & 4.52 & 4.09 & 4.00 & 3.83 & 3.70 & 4.44 & 5.67 & 7.24 \\
\hline 1972 & 4.73 & 5.46 & 4.93 & 4.58 & 4.54 & 4.45 & 4.42 & 5.16 & 6.31 & 7.69 \\
\hline 1973 & 4.57 & 5.24 & 4.74 & 4.39 & 4.35 & 4.24 & 4.19 & 4.81 & 5.74 & 6.79 \\
\hline 1974 & 3.89 & 4.46 & 3.94 & 3.57 & 3.46 & 3.28 & 3.14 & 3.57 & 4.22 & 4.89 \\
\hline 1975 & 4.14 & 4.70 & 4.23 & 3.90 & 3.82 & 3.69 & 3.60 & 4.03 & 4.66 & 5.31 \\
\hline 1976 & 5.13 & 5.71 & 5.33 & 5.10 & 5.11 & 5.09 & 5.12 & 5.65 & 6.40 & 7.18 \\
\hline 1977 & 5.41 & 5.97 & 5.63 & 5.43 & 5.46 & 5.47 & 5.53 & 6.05 & 6.77 & 7.51 \\
\hline 1978 & 5.39 & 5.93 & 5.61 & 5.41 & 5.44 & 5.45 & 5.50 & 5.98 & 6.63 & 7.29 \\
\hline 1979 & 5.05 & 5.54 & 5.22 & 5.01 & 5.02 & 5.00 & 5.02 & 5.43 & 5.98 & 6.53 \\
\hline 1980 & 4.96 & 5.42 & 5.10 & 4.90 & 4.90 & 4.87 & 4.88 & 5.26 & 5.76 & 6.25 \\
\hline 1981 & 4.70 & 5.13 & 4.81 & 4.61 & 4.59 & 4.55 & 4.54 & 4.87 & 5.31 & 5.73 \\
\hline 1982 & 6.08 & 6.56 & 6.32 & 6.19 & 6.26 & 6.30 & 6.39 & 6.82 & 7.36 & 7.90 \\
\hline 1983 & 6.38 & 6.85 & 6.63 & 6.53 & 6.61 & 6.67 & 6.77 & 7.20 & 7.73 & 8.26 \\
\hline 1984 & 6.84 & 7.31 & 7.12 & 7.04 & 7.14 & 7.22 & 7.35 & 7.78 & 8.32 & 8.86 \\
\hline 1985 & 7.44 & 7.91 & 7.76 & 7.71 & 7.83 & 7.94 & 8.10 & 8.55 & 9.11 & 9.66 \\
\hline 1986 & 7.58 & 8.05 & 7.90 & 7.86 & 7.98 & 8.10 & 8.25 & 8.70 & 9.23 & 9.76 \\
\hline 1987 & 7.53 & 7.98 & 7.84 & 7.80 & 7.91 & 8.02 & 8.16 & 8.58 & 9.09 & 9.58 \\
\hline
\end{tabular}




\section{TABLE 5-13 (Continued)}

\begin{tabular}{|c|c|c|c|c|c|c|c|c|c|}
\hline $\begin{array}{l}\text { TO THE } \\
\text { END OF }\end{array}$ & $\begin{array}{l}\text { FROM } \\
1969\end{array}$ & $\underset{1970}{\text { HE BEG }}$ & $\begin{array}{l}\text { JNING OF } \\
1971\end{array}$ & 1972 & 1973 & 1974 & 1975 & 1976 & 1977 \\
\hline 1969 & -1.03 & & & & & & & & \\
\hline 1970 & 6.23 & 14.01 & & & & & & & \\
\hline 1971 & 8.89 & 14.22 & 14.43 & & & & & & \\
\hline 1972 & 9.06 & 12.64 & 11.96 & 9.55 & & & & & \\
\hline 1973 & 7.69 & 9.99 & 8.68 & 5.91 & 2.40 & & & & \\
\hline 1974 & 5.30 & 6.62 & 4.85 & 1.84 & -1.81 & -5.85 & & & \\
\hline 1975 & 5.73 & 6.90 & 5.53 & 3.42 & 1.45 & 0.99 & 8.32 & & \\
\hline 1976 & 7.79 & 9.11 & 8.31 & 7.13 & 6.53 & 7.94 & 15.58 & 23.33 & \\
\hline 1977 & 8.09 & 9.29 & 8.63 & 7.69 & 7.33 & 8.60 & 13.89 & 16.78 & 10.57 \\
\hline 1978 & 7.79 & 8.82 & 8.19 & 7.33 & 6.96 & 7.90 & 11.64 & 12.76 & 7.83 \\
\hline 1979 & 6.91 & 7.74 & 7.06 & 6.18 & 5.70 & 6.27 & 8.87 & 9.01 & 4.61 \\
\hline 1980 & 6.57 & 7.29 & 6.64 & 5.81 & 5.35 & 5.78 & 7.86 & 7.76 & 4.19 \\
\hline 1981 & 5.99 & 6.59 & 5.94 & 5.13 & 4.65 & 4.94 & 6.58 & 6.29 & 3.17 \\
\hline 1982 & 8.30 & 9.05 & 8.65 & 8.14 & 8.00 & 8.64 & 10.60 & 10.93 & 8.99 \\
\hline 1983 & 8.66 & 9.39 & 9.04 & 8.61 & 8.52 & 9.15 & 10.96 & 11.30 & 9.68 \\
\hline 1984 & 9.27 & 10.00 & 9.72 & 9.36 & 9.35 & 10.00 & 11.73 & 12.11 & 10.78 \\
\hline 1985 & 10.10 & 10.84 & 10.63 & 10.36 & 10.43 & 11.12 & 12.81 & 13.27 & 12.21 \\
\hline 1986 & 10.19 & 10.88 & 10.69 & 10.45 & 10.51 & 11.16 & 12.71 & 13.12 & 12.14 \\
\hline 1987 & 9.97 & 10.62 & 10.42 & 10.17 & 10.22 & 10.80 & 12.19 & 12.52 & 11.59 \\
\hline
\end{tabular}

\begin{tabular}{lcrrrrrrrrr} 
TO THE & \multicolumn{2}{c}{ FROM THE BEGINNING OF } & & & & & & \\
END OF & $\mathbf{1 9 7 8}$ & $\mathbf{1 9 7 9}$ & $\mathbf{1 9 8 0}$ & $\mathbf{1 9 8 1}$ & $\mathbf{1 9 8 2}$ & $\mathbf{1 9 8 3}$ & $\mathbf{1 9 8 4}$ & $\mathbf{1 9 8 5}$ & $\mathbf{1 9 8 6}$ & $\mathbf{1 9 8 7}$ \\
1978 & 5.15 & & & & & & & & & \\
1979 & 1.76 & -1.53 & & & & & & & & \\
1980 & 2.15 & 0.68 & 2.93 & & & & & & & \\
1981 & 1.40 & 0.19 & 1.05 & -0.79 & & & & & & \\
1982 & 8.67 & 9.57 & 13.55 & 19.26 & 43.36 & & & & & \\
1983 & 9.53 & 10.42 & 13.63 & 17.44 & 27.78 & 13.89 & & & & \\
1984 & 10.81 & 11.79 & 14.66 & 17.79 & 24.73 & 16.35 & 18.86 & & & \\
1985 & 12.41 & 13.49 & 16.21 & 19.06 & 24.61 & 18.93 & 21.53 & 24.25 & & \\
1986 & 12.32 & 13.25 & 15.53 & 17.78 & 21.89 & 17.05 & 18.12 & 17.75 & 11.59 & \\
1987 & 11.69 & 12.44 & 14.32 & 16.05 & 19.12 & 14.79 & 15.02 & 13.76 & 8.86 & 6.19
\end{tabular}


TABLE 5-14

INDUSTRIAL BONDS: REAL RETURNS

RATES OF RETURN FOR VARIOUS HOLDING PERIODS FROM 1950 TO 1987

\begin{tabular}{|c|c|c|c|c|c|c|c|c|c|}
\hline $\begin{array}{l}\text { TO THE } \\
\text { END OF }\end{array}$ & $\begin{array}{l}\text { FROM } \\
1950\end{array}$ & $\underset{1951}{\text { THE BEG }}$ & ${ }_{1952}^{\text {NING OF }}$ & 1953 & 1954 & 1955 & 1956 & 1957 & 1958 \\
\hline 1950 & -3.23 & & & & & & & & \\
\hline 1951 & -9.57 & -15.49 & & & & & & & \\
\hline 1952 & -4.57 & -5.23 & 6.27 & & & & & & \\
\hline 1953 & -2.50 & -2.25 & 5.13 & 4.00 & & & & & \\
\hline 1954 & -0.13 & 0.66 & 6.71 & 6.93 & 9.94 & & & & \\
\hline 1955 & 0.20 & 0.89 & 5.47 & 5.20 & 5.80 & 1.82 & & & \\
\hline 1956 & -1.39 & -1.09 & 2.08 & 1.05 & 0.09 & -4.50 & -10.42 & & \\
\hline 1957 & -0.56 & -0.18 & 2.63 & 1.92 & 1.41 & -1.28 & -2.80 & 5.46 & \\
\hline 1958 & -0.46 & -0.11 & 2.30 & 1.66 & 1.19 & -0.88 & -1.77 & 2.87 & 0.33 \\
\hline 1959 & -0.98 & -0.73 & 1.29 & 0.60 & 0.04 & -1.83 & -2.72 & -0.01 & -2.64 \\
\hline 1960 & 0.01 & 0.35 & 2.28 & 1.79 & 1.48 & 0.13 & -0.20 & 2.53 & 1.57 \\
\hline 1961 & 0.70 & 1.07 & 2.89 & 2.52 & 2.34 & 1.30 & 1.21 & 3.71 & 3.28 \\
\hline 1962 & 0.90 & 1.25 & 2.93 & 2.60 & 2.45 & 1.55 & 1.51 & 3.65 & 3.29 \\
\hline 1963 & 1.08 & 1.42 & 2.97 & 2.68 & 2.55 & 1.76 & 1.75 & 3.62 & 3.32 \\
\hline 1964 & 1.20 & 1.52 & 2.97 & 2.69 & 2.58 & 1.87 & 1.87 & 3.52 & 3.25 \\
\hline 1965 & 0.90 & 1.18 & 2.49 & 2.20 & 2.06 & 1.37 & 1.32 & 2.72 & 2.38 \\
\hline 1966 & 0.55 & 0.79 & 1.99 & 1.69 & 1.51 & 0.84 & 0.75 & 1.94 & 1.56 \\
\hline 1967 & 0.27 & 0.48 & 1.58 & 1.27 & 1.08 & 0.43 & 0.31 & 1.35 & 0.95 \\
\hline 1968 & 0.18 & 0.37 & 1.39 & 1.09 & 0.90 & 0.28 & 0.17 & 1.10 & 0.72 \\
\hline 1969 & -0.11 & 0.05 & 1.00 & 0.70 & 0.49 & -0.11 & -0.24 & 0.59 & 0.19 \\
\hline 1970 & 0.45 & 0.64 & 1.57 & 1.31 & 1.15 & 0.63 & 0.55 & 1.38 & 1.08 \\
\hline 1971 & 0.83 & 1.02 & 1.93 & 1.71 & 1.58 & 1.11 & 1.07 & 1.88 & 1.63 \\
\hline 1972 & 0.97 & 1.17 & 2.04 & 1.83 & 1.72 & 1.28 & 1.25 & 2.03 & 1.80 \\
\hline 1973 & 0.66 & 0.83 & 1.64 & 1.43 & 1.30 & 0.87 & 0.81 & 1.52 & 1.28 \\
\hline 1974 & -0.08 & 0.06 & 0.80 & 0.55 & 0.39 & -0.06 & -0.16 & 0.44 & 0.15 \\
\hline 1975 & -0.11 & 0.01 & 0.72 & 0.48 & 0.32 & -0.11 & -0.21 & 0.36 & 0.08 \\
\hline 1976 & 0.45 & 0.60 & 1.30 & 1.10 & 0.98 & 0.59 & 0.53 & 1.11 & 0.89 \\
\hline 1977 & 0.47 & 0.61 & 1.29 & 1.10 & 0.98 & 0.61 & 0.55 & 1.11 & 0.89 \\
\hline 1978 & 0.35 & 0.48 & 1.13 & 0.94 & 0.82 & 0.45 & 0.40 & 0.92 & 0.71 \\
\hline 1979 & -0.02 & 0.09 & 0.70 & 0.50 & 0.36 & 0.00 & -0.08 & 0.40 & 0.18 \\
\hline 1980 & -0.27 & -0.17 & 0.41 & 0.20 & 0.06 & -0.30 & -0.38 & 0.06 & -0.17 \\
\hline 1981 & -0.64 & -0.56 & -0.02 & -0.23 & -0.37 & -0.74 & -0.83 & -0.43 & -0.67 \\
\hline 1982 & 0.20 & 0.31 & 0.86 & 0.69 & 0.58 & 0.26 & 0.20 & 0.63 & 0.44 \\
\hline 1983 & 0.45 & 0.56 & 1.11 & 0.95 & 0.85 & 0.55 & 0.50 & 0.93 & 0.76 \\
\hline 1984 & 0.82 & 0.95 & 1.49 & 1.35 & 1.26 & 0.98 & 0.95 & 1.39 & 1.24 \\
\hline 1985 & 1.29 & 1.42 & 1.97 & 1.84 & 1.77 & 1.52 & 1.51 & 1.95 & 1.83 \\
\hline 1986 & 1.44 & 1.58 & 2.11 & 1.99 & 1.93 & 1.69 & 1.69 & 2.12 & 2.01 \\
\hline 1987 & 1.46 & 1.59 & 2.11 & 1.99 & 1.93 & 1.70 & 1.70 & 2.11 & 2.00 \\
\hline
\end{tabular}




\section{TABLE 5-14 (Continued)}

\begin{tabular}{|c|c|c|c|c|c|c|c|c|c|c|}
\hline TO THE & FROM & THE B & IINNIN & OF & & & & & & \\
\hline END OF & 1959 & 1960 & 1961 & 1962 & 1963 & 1964 & 1965 & 1966 & 1967 & 1968 \\
\hline 1959 & -5.52 & & & & & & & & & \\
\hline 1960 & 2.20 & 10.54 & & & & & & & & \\
\hline 1961 & 4.28 & 9.56 & 8.59 & & & & & & & \\
\hline 1962 & 4.04 & 7.44 & 5.92 & 3.31 & & & & & & \\
\hline 1963 & 3.92 & 6.43 & 5.09 & 3.38 & 3.46 & & & & & \\
\hline 1964 & 3.74 & 5.70 & 4.53 & 3.21 & 3.15 & 2.85 & & & & \\
\hline 1965 & 2.68 & 4.11 & 2.87 & 1.49 & 0.89 & -0.37 & -3.50 & & & \\
\hline 1966 & 1.71 & 2.79 & 1.55 & 0.20 & -0.57 & -1.87 & -4.15 & -4.81 & & \\
\hline 1967 & 1.01 & 1.86 & 0.68 & -0.58 & -1.34 & -2.51 & -4.23 & -4.60 & -4.38 & \\
\hline 1968 & 0.75 & 1.48 & 0.40 & -0.72 & -1.38 & -2.32 & -3.57 & -3.59 & -2.98 & -1.55 \\
\hline 1969 & 0.18 & 0.76 & -0.27 & -1.32 & -1.97 & -2.84 & -3.94 & -4.05 & -3.80 & -3.51 \\
\hline 1970 & 1.14 & 1.77 & 0.93 & 0.11 & -0.28 & -0.80 & -1.40 & -0.98 & 0.00 & 1.51 \\
\hline 1971 & 1.73 & 2.36 & 1.65 & 0.98 & 0.72 & 0.38 & 0.04 & 0.64 & 1.76 & 3.36 \\
\hline 1972 & 1.91 & 2.50 & 1.86 & 1.27 & 1.07 & 0.80 & 0.55 & 1.14 & 2.17 & 3.53 \\
\hline 1973 & 1.34 & 1.85 & 1.21 & 0.62 & 0.37 & 0.07 & -0.23 & 0.18 & 0.92 & 1.83 \\
\hline 1974 & 0.14 & 0.53 & -0.15 & -0.79 & -1.12 & -1.53 & -1.96 & -1.78 & -1.40 & -0.96 \\
\hline 1975 & 0.07 & 0.43 & -0.21 & -0.81 & -1.12 & -1.49 & -1.88 & -1.72 & -1.37 & -0.98 \\
\hline 1976 & 0.92 & 1.31 & 0.76 & 0.26 & 0.04 & -0.22 & -0.47 & -0.19 & 0.29 & 0.82 \\
\hline 1977 & 0.92 & 1.29 & 0.77 & 0.30 & 0.11 & -0.13 & -0.35 & -0.09 & 0.35 & 0.84 \\
\hline 1978 & 0.72 & 1.06 & 0.56 & 0.11 & -0.09 & -0.32 & -0.54 & -0.31 & 0.07 & 0.49 \\
\hline 1979 & 0.17 & 0.46 & -0.04 & -0.50 & -0.72 & -0.98 & -1.23 & -1.06 & -0.77 & -0.46 \\
\hline 1980 & -0.19 & 0.07 & -0.43 & -0.88 & -1.11 & -1.37 & -1.63 & -1.50 & -1.26 & -1.02 \\
\hline 1981 & -0.71 & -0.49 & -0.98 & -1.44 & -1.68 & -1.96 & -2.24 & -2.16 & -1.98 & -1.80 \\
\hline 1982 & 0.45 & 0.72 & 0.29 & -0.09 & -0.25 & -0.45 & -0.63 & -0.45 & -0.18 & 0.11 \\
\hline 1983 & 0.78 & 1.05 & 0.65 & 0.31 & 0.17 & 0.00 & -0.14 & 0.05 & 0.34 & 0.64 \\
\hline 1984 & 1.27 & 1.56 & 1.20 & 0.89 & 0.78 & 0.65 & 0.54 & 0.76 & 1.08 & 1.41 \\
\hline 1985 & 1.88 & 2.18 & 1.86 & 1.59 & 1.51 & 1.42 & 1.36 & 1.61 & 1.96 & 2.32 \\
\hline 1986 & 2.07 & 2.36 & 2.06 & 1.80 & 1.74 & 1.67 & 1.61 & 1.86 & 2.21 & 2.57 \\
\hline 1987 & 2.06 & 2.34 & 2.05 & 1.81 & 1.75 & 1.68 & 1.63 & 1.87 & 2.20 & 2.54 \\
\hline
\end{tabular}




\section{TABLE 5-14 (Continued)}

\begin{tabular}{|c|c|c|c|c|c|c|c|c|c|}
\hline $\begin{array}{l}\text { TO THE } \\
\text { END OF }\end{array}$ & $\begin{array}{l}\text { FROM } \\
1969\end{array}$ & $\begin{array}{c}\text { HE BEC } \\
1970\end{array}$ & $\underset{1971}{\text { NNING OF }}$ & 1972 & 1973 & 1974 & 1975 & 1976 & 1977 \\
\hline 1969 & -5.43 & & & & & & & & \\
\hline 1970 & 3.08 & 12.35 & & & & & & & \\
\hline 1971 & 5.05 & 10.72 & 9.12 & & & & & & \\
\hline 1972 & 4.85 & 8.51 & 6.64 & 4.23 & & & & & \\
\hline 1973 & 2.52 & 4.61 & 2.15 & -1.17 & -6.29 & & & & \\
\hline 1974 & -0.87 & 0.07 & -2.78 & -6.45 & -11.37 & -16.18 & & & \\
\hline 1975 & -0.90 & -0.12 & -2.45 & -5.14 & -8.07 & -8.95 & -1.10 & & \\
\hline 1976 & 1.12 & 2.09 & 0.47 & -1.17 & -2.48 & -1.17 & 7.31 & 16.45 & \\
\hline 1977 & 1.11 & 1.96 & 0.55 & -0.81 & -1.79 & -0.63 & 5.17 & 8.46 & 1.02 \\
\hline 1978 & 0.69 & 1.40 & 0.11 & -1.12 & -1.98 & -1.10 & 3.08 & 4.51 & -0.99 \\
\hline 1979 & -0.36 & 0.16 & -1.11 & -2.32 & -3.22 & -2.70 & 0.25 & 0.59 & -4.20 \\
\hline 1980 & -0.97 & -0.56 & -1.76 & -2.90 & -3.76 & -3.39 & -1.07 & -1.07 & -5.02 \\
\hline 1981 & -1.82 & -1.52 & -2.69 & -3.80 & -4.65 & -4.44 & -2.64 & -2.89 & -6.35 \\
\hline 1982 & 0.23 & 0.68 & -0.24 & -1.04 & -1.56 & -1.02 & 1.06 & 1.38 & -0.94 \\
\hline 1983 & 0.79 & 1.25 & 0.44 & -0.25 & -0.65 & -0.06 & 1.91 & 2.29 & 0.42 \\
\hline 1984 & 1.60 & 2.09 & 1.39 & 0.82 & 0.54 & 1.18 & 3.11 & 3.59 & 2.08 \\
\hline 1985 & 2.55 & 3.07 & 2.48 & 2.02 & 1.86 & 2.57 & 4.47 & 5.04 & 3.84 \\
\hline 1986 & 2.80 & 3.31 & 2.77 & 2.36 & 2.22 & 2.91 & 4.69 & 5.23 & 4.17 \\
\hline 1987 & 2.76 & 3.23 & 2.72 & 2.33 & 2.21 & 2.84 & 4.47 & 4.95 & 3.96 \\
\hline
\end{tabular}

TO THE FROM THE BEGINNING OF

$\begin{array}{lllllllllll}\text { END OF } & 1978 & 1979 & 1980 & 1981 & 1982 & 1983 & 1984 & 1985 & 1986 & 1987\end{array}$

\begin{tabular}{|c|c|c|c|c|c|c|c|c|c|}
\hline 1978 & -2.96 & & & & & & & & \\
\hline 1979 & -6.71 & -10.32 & & & & & & & \\
\hline 1980 & -6.95 & -8.89 & -7.43 & & & & & & \\
\hline 1981 & -8.11 & -9.76 & -9.49 & -11.50 & & & & & \\
\hline 1982 & -1.33 & -0.91 & 2.44 & 7.76 & 31.20 & & & & \\
\hline 1983 & 0.32 & 0.98 & 4.03 & 8.15 & 19.55 & 8.94 & & & \\
\hline 1984 & 2.24 & 3.13 & 6.05 & 9.72 & 17.86 & 11.71 & 14.55 & & \\
\hline 1985 & 4.20 & 5.27 & 8.12 & 11.53 & 18.16 & 14.11 & 16.79 & 19.07 & \\
\hline 1986 & 4.52 & 5.50 & 7.97 & 10.78 & 15.87 & 12.32 & 13.47 & 12.94 & 7.12 \\
\hline 1987 & 4.26 & 5.10 & 7.20 & 9.48 & 13.43 & 10.17 & 10.48 & 9.15 & 4.51 \\
\hline
\end{tabular}


TABLE 5-15

CANADIAN EQUITIES: TOTAL RETURNS RATES OF RETURN FOR VARIOUS HOLDING PERIODS FROM 1950 TO 1987

\begin{tabular}{|c|c|c|c|c|c|c|c|c|c|}
\hline $\begin{array}{l}\text { TO THE } \\
\text { END OF }\end{array}$ & $\begin{array}{l}\text { FROM }{ }^{\prime} \\
1950\end{array}$ & $\underset{1951}{\text { HE BEGI }}$ & $\begin{array}{l}\text { NNING OF } \\
1952\end{array}$ & 1953 & 1954 & 1955 & 1956 & 1957 & 1958 \\
\hline 1950 & 27.91 & & & & & & & & \\
\hline 1951 & 26.70 & 25.50 & & & & & & & \\
\hline 1952 & 17.54 & 12.68 & 1.17 & & & & & & \\
\hline 1953 & 10.48 & 5.21 & -3.67 & -8.28 & & & & & \\
\hline 1954 & 16.43 & 13.72 & 10.04 & 14.77 & 43.61 & & & & \\
\hline 1955 & 17.67 & 15.73 & 13.41 & 17.80 & 33.51 & 24.11 & & & \\
\hline 1956 & 16.36 & 14.54 & 12.47 & 15.49 & 24.71 & 16.21 & 8.81 & & \\
\hline 1957 & 10.93 & 8.69 & 6.12 & 7.14 & 11.38 & 2.34 & -7.07 & -20.64 & \\
\hline 1958 & 12.97 & 11.23 & 9.32 & 10.75 & 15.00 & 8.79 & 4.11 & 1.84 & 30.67 \\
\hline 1959 & 11.85 & 10.19 & 8.42 & 9.49 & 12.77 & 7.45 & 3.65 & 1.98 & 15.61 \\
\hline 1960 & 10.87 & 9.29 & 7.62 & 8.46 & 11.09 & 6.43 & 3.21 & 1.86 & 10.69 \\
\hline 1961 & 12.64 & 11.34 & 10.02 & 11.05 & 13.73 & 10.00 & 7.81 & 7.62 & 16.13 \\
\hline 1962 & 10.94 & 9.63 & 8.29 & 9.03 & 11.14 & 7.64 & 5.47 & 4.92 & 10.95 \\
\hline 1963 & 11.17 & 9.97 & 8.77 & 9.49 & 11.44 & 8.35 & 6.52 & 6.20 & 11.48 \\
\hline 1964 & 12.02 & 10.96 & 9.92 & 10.68 & 12.59 & 9.88 & 8.40 & 8.35 & 13.28 \\
\hline 1965 & 11.62 & 10.61 & 9.61 & 10.29 & 12.00 & 9.50 & 8.13 & 8.06 & 12.31 \\
\hline 1966 & 10.55 & 9.54 & 8.56 & 9.10 & 10.57 & 8.19 & 6.84 & 6.65 & 10.21 \\
\hline 1967 & 11.07 & 10.15 & 9.25 & 9.82 & 11.24 & 9.07 & 7.90 & 7.82 & 11.18 \\
\hline 1968 & 11.69 & 10.85 & 10.05 & 10.63 & 12.02 & 10.05 & 9.03 & 9.05 & 12.25 \\
\hline 1969 & 11.00 & 10.18 & 9.38 & 9.89 & 11.13 & 9.25 & 8.26 & 8.22 & 11.05 \\
\hline 1970 & 10.31 & 9.50 & 8.71 & 9.15 & 10.27 & 8.47 & 7.50 & 7.40 & 9.93 \\
\hline 1971 & 10.35 & 9.58 & 8.84 & 9.26 & 10.33 & 8.63 & 7.73 & 7.66 & 10.03 \\
\hline 1972 & 11.15 & 10.44 & 9.77 & 10.22 & 11.29 & 9.73 & 8.93 & 8.94 & 11.27 \\
\hline 1973 & 10.49 & 9.78 & 9.12 & 9.51 & 10.49 & 8.97 & 8.19 & 8.15 & 10.26 \\
\hline 1974 & 8.67 & 7.93 & 7.23 & 7.51 & 8.33 & 6.81 & 5.97 & 5.81 & 7.62 \\
\hline 1975 & 9.16 & 8.47 & 7.81 & 8.11 & 8.92 & 7.50 & 6.73 & 6.62 & 8.38 \\
\hline 1976 & 9.25 & 8.59 & 7.97 & 8.26 & 9.04 & 7.69 & 6.96 & 6.87 & 8.56 \\
\hline 1977 & 9.47 & 8.84 & 8.24 & 8.54 & 9.30 & 8.01 & 7.33 & 7.26 & 8.89 \\
\hline 1978 & 10.10 & 9.51 & 8.96 & 9.27 & 10.04 & 8.83 & 8.21 & 8.18 & 9.79 \\
\hline 1979 & 11.26 & 10.72 & 10.23 & 10.58 & 11.38 & 10.25 & 9.71 & 9.75 & 11.37 \\
\hline 1980 & 11.76 & 11.26 & 10.80 & 11.16 & 11.95 & 10.89 & 10.39 & 10.45 & 12.05 \\
\hline 1981 & 10.97 & 10.47 & 10.00 & 10.31 & 11.04 & 9.99 & 9.48 & 9.51 & 10.99 \\
\hline 1982 & 10.76 & 10.26 & 9.80 & 10.10 & 10.80 & 9.77 & 9.28 & 9.29 & 10.70 \\
\hline 1983 & 11.43 & 10.96 & 10.54 & 10.85 & 11.56 & 10.59 & 10.13 & 10.18 & 11.58 \\
\hline 1984 & 11.10 & 10.64 & 10.21 & 10.51 & 11.18 & 10.23 & 9.78 & 9.82 & 11.15 \\
\hline 1985 & 11.46 & 11.02 & 10.62 & 10.92 & 11.58 & 10.67 & 10.25 & 10.30 & 11.61 \\
\hline 1986 & 11.48 & 11.05 & 10.66 & 10.95 & 11.60 & 10.72 & 10.31 & 10.36 & 11.63 \\
\hline 1987 & 11.15 & 10.73 & 10.34 & 10.62 & 11.23 & 10.37 & 9.97 & 10.00 & 11.21 \\
\hline
\end{tabular}


TABLE 5-15 (Continued)

\begin{tabular}{|c|c|c|c|c|c|c|c|c|c|c|}
\hline $\begin{array}{l}\text { TO THE } \\
\text { END OF }\end{array}$ & $\begin{array}{l}\text { FROM } \\
1959\end{array}$ & $\begin{array}{c}\text { THE B } \\
1960\end{array}$ & $\begin{array}{l}\text { IINNIN } \\
1961\end{array}$ & $\begin{array}{l}\text { OF } \\
1962\end{array}$ & 1963 & 1964 & 1965 & 1966 & 1967 & 1968 \\
\hline 1959 & 2.28 & & & & & & & & & \\
\hline 1960 & 1.88 & 1.49 & & & & & & & & \\
\hline 1961 & 11.65 & 16.65 & 34.09 & & & & & & & \\
\hline 1962 & 6.50 & 7.95 & 11.33 & -7.56 & & & & & & \\
\hline 1963 & 7.99 & 9.47 & 12.27 & 2.73 & 14.18 & & & & & \\
\hline 1964 & 10.61 & 12.36 & 15.26 & 9.58 & 19.32 & 24.69 & & & & \\
\hline 1965 & 9.90 & 11.23 & 13.29 & 8.61 & 14.61 & 14.83 & 5.75 & & & \\
\hline 1966 & 7.89 & 8.71 & 9.97 & 5.69 & 9.29 & 7.71 & 0.11 & -5.24 & & \\
\hline 1967 & 9.20 & 10.10 & 11.39 & 7.99 & 11.41 & 10.73 & 6.43 & 6.77 & 20.29 & \\
\hline 1968 & 10.56 & 11.52 & 12.84 & 10.09 & 13.35 & 13.18 & 10.47 & 12.09 & 21.91 & 23.55 \\
\hline 1969 & 9.42 & 10.16 & 11.17 & 8.60 & 11.12 & 10.62 & 8.01 & 8.58 & 13.62 & 10.42 \\
\hline 1970 & 8.36 & 8.93 & 9.70 & 7.29 & 9.30 & 8.62 & 6.15 & 6.23 & 9.31 & 5.88 \\
\hline 1971 & 8.58 & 9.12 & 9.85 & 7.68 & 9.52 & 8.95 & 6.87 & 7.06 & 9.70 & 7.20 \\
\hline 1972 & 10.00 & 10.61 & 11.41 & 9.55 & 11.43 & 11.12 & 9.54 & 10.09 & 12.87 & 11.44 \\
\hline 1973 & 9.02 & 9.52 & 10.17 & 8.38 & 9.96 & 9.54 & 7.98 & 8.26 & 10.34 & 8.76 \\
\hline 1974 & 6.32 & 6.60 & 6.97 & 5.13 & 6.26 & 5.57 & 3.83 & 3.62 & 4.78 & 2.74 \\
\hline 1975 & 7.20 & 7.51 & 7.93 & 6.26 & 7.41 & 6.87 & 5.38 & 5.34 & 6.59 & 4.99 \\
\hline 1976 & 7.44 & 7.75 & 8.16 & 6.62 & 7.71 & 7.23 & 5.89 & 5.90 & 7.09 & 5.71 \\
\hline 1977 & 7.85 & 8.17 & 8.57 & 7.15 & 8.21 & 7.80 & 6.60 & 6.67 & 7.82 & 6.65 \\
\hline 1978 & 8.83 & 9.19 & 9.64 & 8.34 & 9.43 & 9.12 & 8.08 & 8.26 & 9.47 & 8.54 \\
\hline 1979 & 10.53 & 10.96 & 11.48 & 10.34 & 11.50 & 11.33 & 10.50 & 10.84 & 12.19 & 11.54 \\
\hline 1980 & 11.27 & 11.72 & 12.26 & 11.21 & 12.36 & 12.25 & 11.52 & 11.91 & 13.25 & 12.73 \\
\hline 1981 & 10.20 & 10.58 & 11.03 & 9.99 & 11.00 & 10.82 & 10.06 & 10.33 & 11.46 & 10.85 \\
\hline 1982 & 9.94 & 10.28 & 10.70 & 9.70 & 10.64 & 10.46 & 9.72 & 9.95 & 10.98 & 10.39 \\
\hline 1983 & 10.88 & 11.25 & 11.70 & 10.78 & 11.73 & 11.61 & 10.96 & 11.26 & 12.32 & 11.84 \\
\hline 1984 & 10.46 & 10.80 & 11.20 & 10.30 & 11.19 & 11.05 & 10.41 & 10.66 & 11.62 & 11.13 \\
\hline 1985 & 10.96 & 11.30 & 11.72 & 10.87 & 11.75 & 11.64 & 11.05 & 11.33 & 12.27 & 11.85 \\
\hline 1986 & 11.00 & 11.34 & 11.73 & 10.92 & 11.77 & 11.66 & 11.11 & 11.37 & 12.27 & 11.86 \\
\hline 1987 & 10.59 & 10.90 & 11.26 & 10.47 & 11.26 & 11.14 & 10.58 & 10.81 & 11.64 & 11.22 \\
\hline
\end{tabular}


TABLE 5-15 (Continued)

\begin{tabular}{|c|c|c|c|c|c|c|c|c|c|}
\hline $\begin{array}{l}\text { TO THE } \\
\text { END OF }\end{array}$ & $\begin{array}{l}\text { FROM } \\
1969\end{array}$ & $\underset{1970}{\text { HE BEG }}$ & $\begin{array}{l}1971 \\
\text { JNING OF }\end{array}$ & 1972 & 1973 & 1974 & 1975 & 1976 & 1977 \\
\hline 1969 & -1.32 & & & & & & & & \\
\hline 1970 & -1.98 & -2.65 & & & & & & & \\
\hline 1971 & 2.25 & 4.08 & 11.27 & & & & & & \\
\hline 1972 & 8.61 & 12.13 & 20.34 & 30.16 & & & & & \\
\hline 1973 & 6.02 & 7.94 & 11.72 & 11.94 & -3.72 & & & & \\
\hline 1974 & -0.38 & -0.19 & 0.44 & -2.93 & -16.18 & -27.02 & & & \\
\hline 1975 & 2.57 & 3.23 & 4.45 & 2.81 & -4.96 & -5.57 & 22.18 & & \\
\hline 1976 & 3.67 & 4.41 & 5.63 & 4.54 & -1.04 & -0.12 & 16.84 & 11.72 & \\
\hline 1977 & 4.92 & 5.73 & 6.98 & 6.28 & 2.06 & 3.56 & 16.37 & 13.56 & 15.44 \\
\hline 1978 & 7.14 & 8.12 & 9.55 & 9.31 & 6.17 & 8.27 & 19.49 & 18.60 & 22.20 \\
\hline 1979 & 10.51 & 11.76 & 13.49 & 13.77 & 11.60 & 14.39 & 25.14 & 25.89 & 31.01 \\
\hline 1980 & 11.87 & 13.15 & 14.87 & 15.27 & 13.54 & 16.24 & 25.62 & 26.32 & 30.26 \\
\hline 1981 & 9.93 & 10.92 & 12.25 & 12.34 & 10.52 & 12.45 & 19.61 & 19.18 & 20.74 \\
\hline 1982 & 9.50 & 10.38 & 11.54 & 11.57 & 9.86 & 11.48 & 17.55 & 16.90 & 17.78 \\
\hline 1983 & 11.10 & 12.04 & 13.26 & 13.42 & 12.01 & 13.72 & 19.47 & 19.13 & 20.23 \\
\hline 1984 & 10.39 & 11.22 & 12.28 & 12.36 & 10.99 & 12.44 & 17.41 & 16.89 & 17.55 \\
\hline 1985 & 11.19 & 12.02 & 13.08 & 13.21 & 12.00 & 13.42 & 18.06 & 17.65 & 18.33 \\
\hline 1986 & 11.25 & 12.03 & 13.02 & 13.14 & 12.01 & 13.33 & 17.56 & 17.15 & 17.70 \\
\hline 1987 & 10.61 & 11.31 & 12.19 & 12.25 & 11.15 & 12.29 & 16.08 & 15.58 & 15.94 \\
\hline
\end{tabular}

\begin{tabular}{|c|c|c|c|c|c|c|c|c|c|c|}
\hline \multirow{2}{*}{$\begin{array}{l}\text { TO THE } \\
\text { END OF }\end{array}$} & \multicolumn{4}{|c|}{ FROM THE BEGINNING OF } & \multirow[b]{2}{*}{1982} & \multirow[b]{2}{*}{1983} & \multirow[b]{2}{*}{1984} & \multirow[b]{2}{*}{1985} & \multirow[b]{2}{*}{1986} & \multirow[b]{2}{*}{1987} \\
\hline & 1978 & 1979 & 1980 & 1981 & & & & & & \\
\hline 1978 & 29.36 & & & & & & & & & \\
\hline 1979 & 39.56 & 50.56 & & & & & & & & \\
\hline 1980 & 35.61 & 38.85 & 28.05 & & & & & & & \\
\hline 1981 & 22.10 & 19.77 & 6.82 & -10.89 & & & & & & \\
\hline 1982 & 18.26 & 15.63 & 5.89 & -3.70 & 4.07 & & & & & \\
\hline 1983 & 21.05 & 19.45 & 12.74 & 8.05 & 18.98 & 36.04 & & & & \\
\hline 1984 & 17.85 & 16.04 & 10.15 & 6.08 & 12.42 & 16.85 & 0.37 & & & \\
\hline 1985 & 18.70 & 17.25 & 12.46 & 9.58 & 15.39 & 19.44 & 11.91 & 24.79 & & \\
\hline 1986 & 17.96 & 16.60 & 12.42 & 10.01 & 14.75 & 17.58 & 12.01 & 18.32 & 12.19 & \\
\hline 1987 & 15.99 & 14.60 & 10.75 & 8.48 & 12.09 & 13.77 & 8.80 & 11.77 & 5.77 & -0.28 \\
\hline
\end{tabular}


TABLE 5-16

CANADIAN EQUITIES: REAL RETURNS

RATES OF RETURN FOR VARIOUS HOLDING PERIODS

FROM 1950 TO 1987

\begin{tabular}{|c|c|c|c|c|c|c|c|c|c|}
\hline $\begin{array}{l}\text { TO THE } \\
\text { END OF }\end{array}$ & $\begin{array}{l}\text { FROM } \\
1950\end{array}$ & $\begin{array}{c}\text { HE BEG } \\
1951\end{array}$ & $\begin{array}{l}1952 \\
\text { INING OF }\end{array}$ & 1953 & 1954 & 1955 & 1956 & 1957 & 1958 \\
\hline 1950 & 20.56 & & & & & & & & \\
\hline 1951 & 16.90 & 13.34 & & & & & & & \\
\hline 1952 & 12.05 & 8.02 & 2.95 & & & & & & \\
\hline 1953 & 6.58 & 2.29 & -2.82 & -8.28 & & & & & \\
\hline 1954 & 13.05 & 11.25 & 10.56 & 14.57 & 43.10 & & & & \\
\hline 1955 & 14.76 & 13.63 & 13.70 & 17.53 & 33.04 & 23.68 & & & \\
\hline 1956 & 13.38 & 12.23 & 12.01 & 14.40 & 23.14 & 14.22 & 5.49 & & \\
\hline 1957 & 8.17 & 6.50 & 5.40 & 5.90 & 9.78 & 0.49 & -9.42 & -22.22 & \\
\hline 1958 & 10.14 & 8.90 & 8.28 & 9.20 & 13.08 & 6.61 & 1.46 & -0.50 & 27.29 \\
\hline 1959 & 9.19 & 7.99 & 7.34 & 7.98 & 10.96 & 5.46 & 1.34 & -0.01 & 13.37 \\
\hline 1960 & 8.34 & 7.19 & 6.52 & 6.98 & 9.36 & 4.56 & 1.11 & 0.04 & 8.80 \\
\hline 1961 & 10.25 & 9.36 & 8.97 & 9.66 & 12.14 & 8.30 & 5.93 & 6.01 & 14.55 \\
\hline 1962 & 8.64 & 7.70 & 7.20 & 7.63 & 9.56 & 5.97 & 3.65 & 3.35 & 9.39 \\
\hline 1963 & 8.88 & 8.03 & 7.60 & 8.03 & 9.82 & 6.63 & 4.67 & 4.56 & 9.84 \\
\hline 1964 & 9.74 & 9.00 & 8.68 & 9.17 & 10.91 & 8.12 & 6.51 & 6.64 & 11.56 \\
\hline 1965 & 9.28 & 8.57 & 8.24 & 8.65 & 10.20 & 7.61 & 6.12 & 6.20 & 10.41 \\
\hline 1966 & 8.15 & 7.42 & 7.04 & 7.34 & 8.64 & 6.17 & 4.71 & 4.63 & 8.14 \\
\hline 1967 & 8.55 & 7.88 & 7.54 & 7.86 & 9.11 & 6.86 & 5.57 & 5.57 & 8.85 \\
\hline 1968 & 9.06 & 8.45 & 8.17 & 8.51 & 9.73 & 7.67 & 6.53 & 6.61 & 9.71 \\
\hline 1969 & 8.27 & 7.66 & 7.35 & 7.62 & 8.70 & 6.72 & 5.60 & 5.61 & 8.34 \\
\hline 1970 & 7.65 & 7.04 & 6.72 & 6.93 & 7.90 & 6.01 & 4.93 & 4.89 & 7.33 \\
\hline 1971 & 7.58 & 7.00 & 6.69 & 6.89 & 7.80 & 6.02 & 5.00 & 4.97 & 7.24 \\
\hline 1972 & 8.24 & 7.71 & 7.45 & 7.68 & 8.59 & 6.94 & 6.03 & 6.06 & 8.28 \\
\hline 1973 & 7.31 & 6.77 & 6.48 & 6.65 & 7.46 & 5.85 & 4.94 & 4.91 & 6.89 \\
\hline 1974 & 5.18 & 4.59 & 4.22 & 4.28 & 4.92 & 3.30 & 2.33 & 2.15 & 3.81 \\
\hline 1975 & 5.42 & 4.86 & 4.52 & 4.58 & 5.21 & 3.68 & 2.77 & 2.63 & 4.22 \\
\hline 1976 & 5.42 & 4.88 & 4.55 & 4.62 & 5.22 & 3.76 & 2.90 & 2.77 & 4.29 \\
\hline 1977 & 5.42 & 4.90 & 4.59 & 4.66 & 5.23 & 3.84 & 3.01 & 2.90 & 4.35 \\
\hline 1978 & 5.88 & 5.39 & 5.10 & 5.19 & 5.76 & 4.44 & 3.68 & 3.59 & 5.02 \\
\hline 1979 & 6.79 & 6.35 & 6.11 & 6.22 & 6.83 & 5.58 & 4.89 & 4.86 & 6.30 \\
\hline 1980 & 7.05 & 6.63 & 6.41 & 6.53 & 7.12 & 5.94 & 5.28 & 5.27 & 6.67 \\
\hline 1981 & 6.06 & 5.63 & 5.38 & 5.46 & 5.99 & 4.82 & 4.15 & 4.10 & 5.37 \\
\hline 1982 & 5.72 & 5.28 & 5.03 & 5.10 & 5.60 & 4.46 & 3.81 & 3.74 & 4.95 \\
\hline 1983 & 6.37 & 5.96 & 5.74 & 5.83 & 6.34 & 5.25 & 4.65 & 4.62 & 5.82 \\
\hline 1984 & 6.08 & 5.68 & 5.45 & 5.53 & 6.01 & 4.96 & 4.36 & 4.32 & 5.47 \\
\hline 1985 & 6.43 & 6.05 & 5.85 & 5.93 & 6.41 & 5.40 & 4.84 & 4.82 & 5.94 \\
\hline 1986 & 6.46 & 6.10 & 5.90 & 5.99 & 6.45 & 5.47 & 4.93 & 4.91 & 6.00 \\
\hline 1987 & 6.17 & 5.80 & 5.60 & 5.68 & 6.12 & 5.16 & 4.63 & 4.60 & 5.64 \\
\hline
\end{tabular}




\section{TABLE 5-16 (Continued)}

\begin{tabular}{|c|c|c|c|c|c|c|c|c|c|}
\hline FROM & THE B & SINNI & & & & & & & \\
\hline 1959 & 1960 & 1961 & 1962 & 1963 & 1964 & 1965 & 1966 & 1967 & 1968 \\
\hline 0.97 & & & & & & & & & \\
\hline 0.59 & 0.21 & & & & & & & & \\
\hline 10.59 & 15.73 & 33.67 & & & & & & & \\
\hline 5.33 & 6.82 & 10.29 & -8.99 & & & & & & \\
\hline 6.65 & 8.12 & 10.89 & 1.00 & 12.10 & & & & & \\
\hline 9.13 & 10.84 & 13.68 & 7.70 & 17.16 & 22.46 & & & & \\
\hline 8.19 & 9.44 & 11.39 & 6.42 & 12.12 & 12.14 & 2.68 & & & \\
\hline 5.96 & 6.69 & 7.81 & 3.27 & 6.59 & 4.82 & -3.03 & -8.42 & & \\
\hline 6.97 & 7.75 & 8.87 & 5.21 & 8.30 & 7.38 & 2.77 & 2.82 & 15.44 & \\
\hline 8.10 & 8.92 & 10.06 & 7.05 & 9.98 & 9.56 & 6.56 & 7.88 & 17.09 & 18.77 \\
\hline 6.76 & 7.36 & 8.19 & 5.36 & 7.59 & 6.86 & 3.99 & 4.31 & 8.94 & 5.83 \\
\hline 5.82 & 6.27 & 6.89 & 4.27 & 6.06 & 5.22 & 2.60 & 2.58 & 5.53 & 2.42 \\
\hline 5.84 & 6.25 & 6.82 & 4.45 & 6.06 & 5.33 & 3.09 & 3.16 & 5.65 & 3.33 \\
\hline 7.03 & 7.51 & 8.15 & 6.08 & 7.72 & 7.25 & 5.48 & 5.89 & 8.48 & 7.14 \\
\hline 5.65 & 6.00 & 6.45 & 4.45 & 5.77 & 5.16 & 3.39 & 3.48 & 5.30 & 3.70 \\
\hline 2.49 & 2.59 & 2.77 & 0.71 & 1.56 & 0.65 & -1.30 & -1.73 & -0.86 & -3.00 \\
\hline 3.00 & 3.13 & 3.33 & 1.45 & 2.30 & 1.52 & -0.20 & -0.48 & 0.44 & -1.29 \\
\hline 3.14 & 3.27 & 3.46 & 1.71 & 2.52 & 1.82 & 0.27 & 0.05 & 0.94 & -0.56 \\
\hline 3.26 & 3.39 & 3.58 & 1.94 & 2.72 & 2.08 & 0.66 & 0.49 & 1.34 & 0.03 \\
\hline 4.01 & 4.17 & 4.40 & 2.89 & 3.69 & 3.15 & 1.89 & 1.83 & 2.73 & $\begin{array}{l}0.05 \\
1.65\end{array}$ \\
\hline 5.39 & 5.62 & 5.91 & 4.55 & 5.40 & 5.00 & 3.93 & 4.02 & 5.04 & $\begin{array}{l}1.00 \\
4.22\end{array}$ \\
\hline 5.82 & 6.05 & 6.35 & 5.08 & 5.92 & 5.57 & 4.60 & 4.73 & 5.73 & 5.02 \\
\hline 4.51 & 4.67 & 4.89 & 3.63 & 4.34 & 3.92 & 2.92 & 2.94 & 3.74 & 2.95 \\
\hline 4.10 & 4.24 & 4.43 & 3.21 & 3.86 & 3.44 & 2.48 & 2.47 & 3.19 & 2.42 \\
\hline 5.04 & 5.21 & 5.43 & 4.30 & 4.98 & 4.64 & 3.78 & 3.84 & 4.61 & 3.96 \\
\hline 4.71 & 4.86 & 5.06 & 3.96 & 4.59 & 4.25 & 3.41 & 3.45 & 4.15 & 3.52 \\
\hline 5.22 & 5.39 & 5.60 & 4.57 & 5.20 & 4.90 & 4.13 & 4.20 & 4.91 & 4.36 \\
\hline 5.31 & 5.47 & 5.68 & 4.69 & 5.31 & 5.02 & 4.29 & 4.37 & 5.05 & 4.53 \\
\hline 4.96 & 5.11 & 5.30 & 4.33 & 4.91 & 4.62 & 3.90 & 3.96 & 4.59 & 4.07 \\
\hline
\end{tabular}




\section{TABLE 5-16 (Continued)}

\begin{tabular}{|c|c|c|c|c|c|c|c|c|c|}
\hline $\begin{array}{l}\text { TO THE } \\
\text { END OF }\end{array}$ & $\begin{array}{l}\text { FROM } \\
1969\end{array}$ & $\underset{1970}{\text { HE BEG }}$ & $\begin{array}{l}1971 \\
\text { NING OF }\end{array}$ & 1972 & 1973 & 1974 & 1975 & 1976 & 1977 \\
\hline 1969 & -5.70 & & & & & & & & \\
\hline 1970 & -4.89 & -4.07 & & & & & & & \\
\hline 1971 & -1.36 & 0.89 & 6.11 & & & & & & \\
\hline 1972 & 4.42 & 8.02 & 14.63 & 23.84 & & & & & \\
\hline 1973 & 0.93 & 2.66 & 5.00 & 4.46 & -11.89 & & & & \\
\hline 1974 & -6.21 & -6.32 & -6.87 & -10.83 & -24.34 & -35.02 & & & \\
\hline 1975 & -3.86 & -3.55 & -3.45 & -5.70 & -13.89 & -14.86 & 11.55 & & \\
\hline 1976 & -2.74 & -2.31 & -2.01 & -3.56 & -9.40 & -8.56 & 8.48 & 5.49 & \\
\hline 1977 & -1.86 & -1.37 & -0.98 & -2.11 & -6.61 & -5.24 & 7.46 & 5.48 & 5.46 \\
\hline 1978 & 0.08 & 0.75 & 1.36 & 0.70 & -2.71 & -0.76 & 10.33 & 9.92 & 12.21 \\
\hline 1979 & 2.99 & 3.90 & 4.83 & 4.67 & 2.18 & 4.74 & 15.23 & 16.17 & 19.96 \\
\hline 1980 & 3.95 & 4.88 & 5.82 & 5.78 & 3.72 & 6.17 & 15.22 & 15.97 & 18.75 \\
\hline 1981 & 1.83 & 2.48 & 3.10 & 2.80 & 0.70 & 2.39 & 9.27 & 8.89 & 9.59 \\
\hline 1982 & 1.34 & 1.91 & 2.42 & 2.09 & 0.14 & 1.57 & 7.41 & 6.83 & 7.05 \\
\hline 1983 & 3.05 & 3.70 & 4.32 & 4.18 & 2.55 & 4.12 & 9.72 & 9.50 & 10.08 \\
\hline 1984 & 2.64 & 3.22 & 3.76 & 3.58 & 2.05 & 3.43 & 8.35 & 8.00 & 8.32 \\
\hline 1985 & 3.57 & 4.18 & 4.75 & 4.65 & 3.31 & 4.69 & 9.32 & 9.10 & 9.51 \\
\hline 1986 & 3.79 & 4.38 & 4.93 & 4.85 & 3.61 & 4.91 & 9.19 & 8.98 & 9.33 \\
\hline 1987 & 3.35 & 3.88 & 4.37 & 4.26 & 3.07 & 4.23 & 8.09 & 7.81 & 8.02 \\
\hline
\end{tabular}

TO THE FROM THE BEGINNING OF

$\begin{array}{lllllllllll}\text { END OF } & 1978 & 1979 & 1980 & 1981 & 1982 & 1983 & 1984 & 1985 & 1986 & 1987\end{array}$

\begin{tabular}{|c|c|c|c|c|c|c|c|c|c|}
\hline 1978 & 19.39 & & & & & & & & \\
\hline 1979 & 27.95 & 37.12 & & & & & & & \\
\hline 1980 & 23.54 & 25.66 & 15.16 & & & & & & \\
\hline 1981 & 10.64 & 7.87 & -4.32 & -20.51 & & & & & \\
\hline 1982 & 7.38 & 4.57 & -4.47 & -12.99 & -4.76 & & & & \\
\hline 1983 & 10.87 & 9.24 & 3.21 & -0.50 & 11.32 & 30.12 & & & \\
\hline 1984 & 8.73 & 7.05 & 1.88 & -1.20 & 6.23 & 12.19 & -3.27 & & \\
\hline 1985 & 10.03 & 8.76 & 4.64 & 2.65 & 9.42 & 14.60 & 7.55 & 19.59 & \\
\hline 1986 & 9.77 & 8.62 & 5.07 & 3.47 & 9.08 & 12.84 & 7.60 & 13.49 & 7.70 \\
\hline 1987 & 8.28 & 7.11 & 3.85 & 2.33 & 6.73 & 9.19 & 4.51 & 7.24 & 1.55 \\
\hline
\end{tabular}


TABLE 5-17

CONSUMER PRICE INDEX: TOTAL RETURNS

RATES OF RETURN FOR VARIOUS HOLDING PERIODS

FROM 1950 TO 1987

\begin{tabular}{|c|c|c|c|c|c|c|c|c|c|}
\hline $\begin{array}{l}\text { TO THE } \\
\text { END OF }\end{array}$ & $\begin{array}{l}\text { FROM } \\
1950\end{array}$ & $\underset{1951}{\text { HE BEG }}$ & $\begin{array}{l}\text { INING OF } \\
1952\end{array}$ & 1953 & 1954 & 1955 & 1956 & 1957 & 1958 \\
\hline $\begin{array}{l}1950 \\
1951\end{array}$ & $\begin{array}{l}6.10 \\
8.39\end{array}$ & 10.73 & & & & & & & \\
\hline 1952 & 4.90 & 4.31 & -1.73 & & & & & & \\
\hline 1953 & 3.66 & 2.85 & -0.87 & 0.00 & & & & & \\
\hline 1954 & 2.99 & 2.22 & -0.46 & 0.18 & 0.35 & & & & \\
\hline 1955 & 2.54 & 1.85 & -0.26 & 0.23 & 0.35 & 0.35 & & & \\
\hline 1956 & 2.63 & 2.06 & 0.41 & 0.95 & 1.27 & 1.74 & 3.15 & & \\
\hline 1957 & 2.55 & 2.06 & 0.68 & 1.17 & 1.46 & 1.84 & 2.59 & 2.03 & \\
\hline 1958 & 2.57 & 2.13 & 0.96 & 1.42 & 1.70 & 2.04 & 2.61 & 2.34 & 2.66 \\
\hline 1959 & 2.44 & 2.04 & 1.00 & 1.40 & 1.63 & 1.89 & 2.28 & 1.99 & 1.97 \\
\hline 1960 & 2.33 & 1.96 & 1.03 & 1.38 & 1.58 & 1.79 & 2.08 & 1.81 & 1.74 \\
\hline 1961 & 2.16 & 1.81 & 0.96 & 1.26 & 1.42 & 1.58 & 1.78 & 1.51 & 1.38 \\
\hline 1962 & 2.12 & 1.79 & 1.02 & 1.29 & 1.44 & 1.58 & 1.75 & 1.52 & 1.42 \\
\hline 1963 & 2.10 & 1.80 & 1.09 & 1.35 & 1.48 & 1.61 & 1.77 & 1.57 & 1.49 \\
\hline 1964 & 2.08 & 1.80 & 1.14 & 1.39 & 1.51 & 1.63 & 1.77 & 1.60 & 1.54 \\
\hline 1965 & 2.14 & 1.88 & 1.27 & 1.51 & 1.63 & 1.75 & 1.89 & 1.75 & 1.72 \\
\hline 1966 & 2.21 & 1.98 & 1.42 & 1.65 & 1.78 & 1.89 & 2.04 & 1.93 & 1.91 \\
\hline 1967 & 2.32 & 2.11 & 1.59 & 1.82 & 1.95 & 2.07 & 2.21 & 2.13 & 2.14 \\
\hline 1968 & 2.41 & 2.21 & 1.73 & 1.95 & 2.08 & 2.21 & 2.35 & 2.29 & 2.31 \\
\hline 1969 & 2.52 & 2.34 & 1.89 & 2.11 & 2.24 & 2.37 & 2.52 & 2.47 & 2.50 \\
\hline 1970 & 2.47 & 2.30 & 1.87 & 2.07 & 2.20 & 2.31 & 2.45 & 2.40 & 2.42 \\
\hline 1971 & 2.58 & 2.42 & 2.02 & 2.22 & 2.34 & 2.46 & 2.60 & 2.56 & 2.60 \\
\hline 1972 & 2.69 & 2.54 & 2.16 & 2.36 & 2.49 & 2.61 & 2.74 & 2.72 & 2.76 \\
\hline 1973 & 2.96 & 2.82 & 2.48 & 2.68 & 2.82 & 2.95 & 3.09 & 3.09 & 3.16 \\
\hline 1974 & 3.32 & 3.20 & 2.89 & 3.10 & 3.25 & 3.40 & 3.56 & 3.58 & 3.68 \\
\hline 1975 & 3.55 & 3.45 & 3.15 & 3.37 & 3.53 & 3.68 & 3.85 & 3.89 & 3.99 \\
\hline 1976 & 3.63 & 3.54 & 3.26 & 3.48 & 3.63 & 3.78 & 3.95 & 3.99 & 4.09 \\
\hline 1977 & 3.84 & 3.75 & 3.49 & 3.71 & 3.87 & 4.02 & 4.19 & 4.24 & 4.35 \\
\hline 1978 & 3.99 & 3.91 & 3.67 & 3.88 & 4.04 & 4.20 & 4.37 & 4.43 & 4.54 \\
\hline 1979 & 4.18 & 4.11 & 3.88 & 4.10 & 4.26 & 4.42 & 4.59 & 4.65 & 4.78 \\
\hline 1980 & 4.40 & 4.34 & 4.13 & 4.34 & 4.51 & 4.67 & 4.85 & 4.92 & 5.05 \\
\hline 1981 & 4.63 & 4.58 & 4.38 & 4.60 & 4.77 & 4.94 & 5.12 & 5.20 & 5.33 \\
\hline 1982 & 4.77 & 4.73 & 4.54 & 4.75 & 4.92 & 5.09 & 5.27 & 5.35 & 5.49 \\
\hline 1983 & 4.76 & 4.72 & 4.54 & 4.75 & 4.91 & 5.07 & 5.24 & 5.32 & 5.45 \\
\hline 1984 & 4.73 & 4.69 & 4.51 & 4.72 & 4.87 & 5.03 & 5.19 & 5.26 & 5.39 \\
\hline 1985 & 4.72 & 4.68 & 4.51 & 4.70 & 4.86 & 5.00 & 5.16 & 5.23 & 5.35 \\
\hline 1986 & 4.71 & 4.67 & $4.50^{\prime}$ & 4.69 & 4.83 & 4.98 & 5.13 & 5.20 & 5.31 \\
\hline 1987 & 4.69 & 4.65 & 4.49 & 4.67 & 4.81 & 4.95 & 5.10 & 5.16 & 5.27 \\
\hline
\end{tabular}




\section{TABLE 5-17 (Continued)}

$\begin{array}{lllllllllll}\text { TO THE } & \text { FROM THE BEGINNING OF } & & & & & \\ \text { END OF } & \mathbf{1 9 5 9} & \mathbf{1 9 6 0} & \mathbf{1 9 6 1} & \mathbf{1 9 6 2} & \mathbf{1 9 6 3} & \mathbf{1 9 6 4} & \mathbf{1 9 6 5} & \mathbf{1 9 6 6} & \mathbf{1 9 6 7} & \mathbf{1 9 6 8} \\ & & & & & & & & & & \\ 1959 & 1.29 & & & & & & & & & \\ 1960 & 1.29 & 1.28 & & & & & & & & \\ 1961 & 0.96 & 0.80 & 0.32 & & & & & & & \\ 1962 & 1.11 & 1.05 & 0.94 & 1.57 & & & & & & \\ 1963 & 1.26 & 1.25 & 1.25 & 1.71 & 1.86 & & & & & \\ 1964 & 1.36 & 1.37 & 1.39 & 1.75 & 1.84 & 1.82 & & & & \\ 1965 & 1.59 & 1.64 & 1.71 & 2.06 & 2.22 & 2.40 & 2.98 & & & \\ 1966 & 1.82 & 1.90 & 2.00 & 2.34 & 2.53 & 2.76 & 3.23 & 3.48 & & \\ 1967 & 2.08 & 2.18 & 2.31 & 2.65 & 2.86 & 3.12 & 3.55 & 3.84 & 4.20 & \\ 1968 & 2.28 & 2.39 & 2.53 & 2.84 & 3.06 & 3.30 & 3.67 & 3.90 & 4.12 & 4.03 \\ 1969 & 2.49 & 2.61 & 2.76 & 3.07 & 3.28 & 3.52 & 3.87 & 4.09 & 4.29 & 4.34 \\ 1970 & 2.41 & 2.51 & 2.63 & 2.89 & 3.06 & 3.23 & 3.47 & 3.56 & 3.58 & 3.38 \\ 1971 & 2.59 & 2.70 & 2.83 & 3.09 & 3.26 & 3.43 & 3.66 & 3.78 & 3.84 & 3.75 \\ 1972 & 2.77 & 2.88 & 3.02 & 3.27 & 3.44 & 3.62 & 3.84 & 3.97 & 4.05 & 4.02 \\ 1973 & 3.19 & 3.33 & 3.49 & 3.76 & 3.96 & 4.17 & 4.43 & 4.62 & 4.78 & 4.88 \\ 1974 & 3.74 & 3.90 & 4.09 & 4.39 & 4.63 & 4.89 & 5.20 & 5.44 & 5.69 & 5.91 \\ 1975 & 4.07 & 4.25 & 4.45 & 4.75 & 5.00 & 5.26 & 5.58 & 5.85 & 6.11 & 6.35 \\ 1976 & 4.17 & 4.34 & 4.54 & 4.83 & 5.06 & 5.31 & 5.61 & 5.85 & 6.09 & 6.31 \\ 1977 & 4.44 & 4.62 & 4.82 & 5.11 & 5.35 & 5.60 & 5.90 & 6.15 & 6.39 & 6.62 \\ 1978 & 4.64 & 4.82 & 5.02 & 5.30 & 5.54 & 5.79 & 6.08 & 6.32 & 6.56 & 6.77 \\ 1979 & 4.88 & 5.06 & 5.26 & 5.54 & 5.78 & 6.03 & 6.32 & 6.56 & 6.80 & 7.02 \\ 1980 & 5.16 & 5.34 & 5.55 & 5.83 & 6.08 & 6.33 & 6.62 & 6.86 & 7.11 & 7.34 \\ 1981 & 5.45 & 5.64 & 5.85 & 6.14 & 6.38 & 6.64 & 6.93 & 7.18 & 7.44 & 7.67 \\ 1982 & 5.60 & 5.80 & 6.01 & 6.29 & 6.53 & 6.78 & 7.06 & 7.31 & 7.55 & 7.78 \\ 1983 & 5.56 & 5.74 & 5.94 & 6.21 & 6.43 & 6.67 & 6.93 & 7.15 & 7.37 & 7.57 \\ 1984 & 5.49 & 5.66 & 5.85 & 6.10 & 6.31 & 6.53 & 6.77 & 6.97 & 7.17 & 7.34 \\ 1985 & 5.45 & 5.61 & 5.79 & 6.02 & 6.22 & 6.43 & 6.65 & 6.84 & 7.02 & 7.17 \\ 1986 & 5.40 & 5.56 & 5.73 & 5.95 & 6.14 & 6.33 & 6.54 & 6.71 & 6.87 & 7.01 \\ 1987 & 5.36 & 5.51 & 5.67 & 5.88 & 6.06 & 6.24 & 6.43 & 6.59 & 6.74 & 6.87\end{array}$


TABLE 5-17 (Continued)

\begin{tabular}{llllllllll} 
TO THE & \multicolumn{2}{l}{ FROM THE BEGINNING OF } & & & & & \\
END OF & $\mathbf{1 9 6 9}$ & $\mathbf{1 9 7 0}$ & $\mathbf{1 9 7 1}$ & $\mathbf{1 9 7 2}$ & $\mathbf{1 9 7 3}$ & $\mathbf{1 9 7 4}$ & $\mathbf{1 9 7 5}$ & $\mathbf{1 9 7 6}$ & $\mathbf{1 9 7 7}$ \\
1969 & 4.65 & & & & & & & & \\
1970 & 3.05 & 1.48 & & & & & & & \\
1971 & 3.65 & 3.16 & 4.87 & & & & & & \\
1972 & 4.01 & 3.80 & 4.98 & 5.10 & & & & & \\
1973 & 5.05 & 5.14 & 6.39 & 7.17 & 9.27 & & & & \\
1974 & 6.22 & 6.54 & 7.85 & 8.86 & 10.79 & 12.32 & & & \\
1975 & 6.69 & 7.03 & 8.18 & 9.03 & 10.37 & 10.92 & 9.53 & & \\
1976 & 6.59 & 6.87 & 7.80 & 8.40 & 9.24 & 9.22 & 7.71 & 5.91 & \\
1977 & 6.91 & 7.19 & 8.03 & 8.57 & 9.28 & 9.28 & 8.29 & 7.67 & 9.46 \\
1978 & 7.05 & 7.32 & 8.07 & 8.54 & 9.13 & 9.10 & 8.30 & 7.90 & 8.91 \\
1979 & 7.30 & 7.57 & 8.27 & 8.70 & 9.22 & 9.21 & 8.60 & 8.37 & 9.20 \\
1980 & 7.62 & 7.89 & 8.55 & 8.97 & 9.47 & 9.49 & 9.03 & 8.93 & 9.70 \\
1981 & 7.96 & 8.24 & 8.87 & 9.28 & 9.76 & 9.82 & 9.46 & 9.45 & 10.17 \\
1982 & 8.05 & 8.31 & 8.90 & 9.28 & 9.71 & 9.75 & 9.44 & 9.42 & 10.02 \\
1983 & 7.81 & 8.04 & 8.56 & 8.88 & 9.23 & 9.22 & 8.88 & 8.80 & 9.22 \\
1984 & 7.55 & 7.75 & 8.21 & 8.47 & 8.76 & 8.71 & 8.36 & 8.23 & 8.52 \\
1985 & 7.36 & 7.53 & 7.95 & 8.17 & 8.41 & 8.34 & 7.99 & 7.84 & 8.05 \\
1986 & 7.18 & 7.33 & 7.71 & 7.90 & 8.11 & 8.02 & 7.67 & 7.50 & 7.66 \\
1987 & 7.02 & 7.15 & 7.50 & 7.66 & 7.84 & 7.74 & 7.39 & 7.21 & 7.33
\end{tabular}

\begin{tabular}{lrrrrrrrrrr} 
TO THE & \multicolumn{2}{c}{ FROM THE BEGINNING OF } & & & & & & \\
END OF & $\mathbf{1 9 7 8}$ & $\mathbf{1 9 7 9}$ & $\mathbf{1 9 8 0}$ & $\mathbf{1 9 8 1}$ & $\mathbf{1 9 8 2}$ & $\mathbf{1 9 8 3}$ & $\mathbf{1 9 8 4}$ & $\mathbf{1 9 8 5}$ & $\mathbf{1 9 8 6}$ & $\mathbf{1 9 8 7}$ \\
1978 & 8.36 & & & & & & & & & \\
1979 & 9.08 & 9.80 & & & & & & & & \\
1980 & 9.78 & 10.49 & 11.19 & & & & & & & \\
1981 & 10.35 & 11.03 & 11.64 & 12.10 & & & & & & \\
1982 & 10.13 & 10.58 & 10.84 & 10.67 & 9.26 & & & & & \\
1983 & 9.18 & 9.35 & 9.23 & 8.59 & 6.88 & 4.55 & & & & \\
1984 & 8.39 & 8.40 & 8.12 & 7.36 & 5.83 & 4.15 & 3.76 & & & \\
1985 & 7.88 & 7.81 & 7.48 & 6.75 & 5.46 & 4.22 & 4.06 & 4.35 & & \\
1986 & 7.46 & 7.35 & 7.00 & 6.32 & 5.20 & 4.21 & 4.09 & 4.26 & 4.17 & \\
1987 & 7.12 & 6.99 & 6.64 & 6.01 & 5.02 & 4.20 & 4.11 & 4.22 & 4.16 & 4.15
\end{tabular}


TABLE 5-18

U.S. CRSP EQUITIES (EXCHANGE RATE ADJUSTED): TOTAL RETURNS RATES OF RETURN FOR VARIOUS HOLDING PERIODS FROM 1950 TO 1986

\begin{tabular}{|c|c|c|c|c|c|c|c|c|c|}
\hline $\begin{array}{l}\text { TO THE } \\
\text { END OF }\end{array}$ & $\begin{array}{l}\text { FROM } \\
1950\end{array}$ & $\begin{array}{c}\mathrm{HE} \mathrm{BEC} \\
1951\end{array}$ & $\begin{array}{l}\text { INING OF } \\
1952\end{array}$ & 1953 & 1954 & 1955 & 1956 & 1957 & 1958 \\
\hline 1950 & 24.06 & & & & & & & & \\
\hline 1951 & 20.84 & 17.71 & & & & & & & \\
\hline 1952 & 16.13 & 12.36 & 7.25 & & & & & & \\
\hline 1953 & 12.03 & 8.28 & 3.86 & 0.57 & & & & & \\
\hline 1954 & 18.68 & 17.37 & 17.26 & 22.62 & 49.49 & & & & \\
\hline 1955 & 20.40 & 19.68 & 20.18 & 24.83 & 39.07 & 29.37 & & & \\
\hline 1956 & 17.93 & 16.94 & 16.79 & 19.31 & 26.30 & 16.09 & 4.16 & & \\
\hline 1957 & 14.18 & 12.83 & 12.04 & 13.02 & 16.37 & 7.05 & -2.63 & -8.97 & \\
\hline 1958 & 17.06 & 16.21 & 16.00 & 17.53 & 21.25 & 15.07 & 10.66 & 14.06 & 42.91 \\
\hline 1959 & 16.49 & 15.68 & 15.43 & 16.65 & 19.57 & 14.35 & 10.87 & 13.20 & 26.24 \\
\hline 1960 & 15.32 & 14.48 & 14.12 & 15.01 & 17.24 & 12.58 & 9.50 & 10.87 & 18.41 \\
\hline 1961 & 16.86 & 16.23 & 16.08 & 17.10 & 19.35 & 15.57 & 13.42 & 15.37 & 22.41 \\
\hline 1962 & 14.82 & 14.08 & 13.75 & 14.43 & 16.08 & 12.46 & 10.24 & 11.28 & 15.85 \\
\hline 1963 & 15.30 & 14.65 & 14.40 & 15.08 & 16.64 & 13.46 & 11.62 & 12.73 & 16.82 \\
\hline 1964 & 15.34 & 14.74 & 14.52 & 15.14 & 16.57 & 13.70 & 12.08 & 13.12 & 16.68 \\
\hline 1965 & 15.27 & 14.70 & 14.49 & 15.07 & 16.37 & 13.75 & 12.29 & 13.23 & 16.37 \\
\hline 1966 & 13.73 & 13.12 & 12.82 & 13.22 & 14.26 & 11.73 & 10.25 & 10.88 & 13.34 \\
\hline 1967 & 14.41 & 13.86 & 13.62 & 14.06 & 15.09 & 12.80 & 11.52 & 12.21 & 14.59 \\
\hline 1968 & 14.28 & 13.76 & 13.53 & 13.93 & 14.89 & 12.74 & 11.56 & 12.20 & 14.35 \\
\hline 1969 & 12.94 & 12.38 & 12.09 & 12.39 & 13.17 & 11.09 & 9.88 & 10.34 & 12.12 \\
\hline 1970 & 12.06 & 11.50 & 11.18 & 11.40 & 12.07 & 10.07 & 8.89 & 9.24 & 10.78 \\
\hline 1971 & 12.14 & 11.60 & 11.31 & 11.53 & 12.17 & 10.29 & 9.19 & 9.54 & 11.00 \\
\hline 1972 & 12.36 & 11.86 & 11.59 & 11.81 & 12.43 & 10.67 & 9.66 & 10.01 & 11.41 \\
\hline 1973 & 10.97 & 10.44 & 10.12 & 10.25 & 10.76 & 9.03 & 8.00 & 8.23 & 9.40 \\
\hline 1974 & 9.09 & 8.51 & 8.13 & 8.17 & 8.54 & 6.82 & 5.75 & 5.84 & 6.78 \\
\hline 1975 & 10.18 & 9.66 & 9.34 & 9.43 & 9.85 & 8.25 & 7.29 & 7.46 & 8.45 \\
\hline 1976 & 10.76 & 10.28 & 9.99 & 10.11 & 10.54 & 9.03 & 8.15 & 8.35 & 9.35 \\
\hline 1977 & 10.45 & 9.98 & 9.69 & 9.79 & 10.19 & 8.74 & 7.89 & 8.07 & 9.00 \\
\hline 1978 & 10.62 & 10.17 & 9.90 & 10.00 & 10.40 & 9.01 & 8.20 & 8.39 & 9.29 \\
\hline 1979 & 10.95 & 10.52 & 10.27 & 10.39 & 10.78 & 9.46 & 8.70 & 8.90 & 9.80 \\
\hline 1980 & 11.67 & 11.28 & 11.07 & 11.20 & 11.62 & 10.37 & 9.67 & 9.91 & 10.81 \\
\hline 1981 & 11.10 & 10.71 & 10.48 & 10.60 & 10.97 & 9.76 & 9.06 & 9.26 & 10.10 \\
\hline 1982 & 11.54 & 11.17 & 10.97 & 11.09 & 11.47 & 10.31 & 9.66 & 9.88 & 10.71 \\
\hline 1983 & 11.89 & 11.54 & 11.35 & 11.49 & 11.87 & 10.76 & 10.15 & 10.37 & 11.19 \\
\hline 1984 & 11.89 & 11.55 & 11.37 & 11.50 & 11.88 & 10.80 & 10.21 & 10.43 & 11.22 \\
\hline 1985 & 12.56 & 12.25 & 12.09 & 12.24 & 12.63 & 11.61 & 11.06 & 11.30 & 12.10 \\
\hline 1986 & 12.64 & 12.34 & 12.19 & 12.34 & 12.72 & 11.73 & 11.20 & 11.44 & 12.22 \\
\hline
\end{tabular}




\section{TABLE 5-18 (Continued)}

\begin{tabular}{|c|c|c|c|c|c|c|c|c|c|c|}
\hline TO THE & FROM & THE & GINNIN & OF & & & & & & \\
\hline END OF & 1959 & 1960 & 1961 & 1962 & 1963 & 1964 & 1965 & 1966 & 1967 & 1968 \\
\hline 1959 & 11.51 & & & & & & & & & \\
\hline 1960 & 7.78 & 4.17 & & & & & & & & \\
\hline 1961 & 16.25 & 18.70 & 35.25 & & & & & & & \\
\hline 1962 & 9.92 & 9.40 & 12.10 & -7.08 & & & & & & \\
\hline 1963 & 12.20 & 12.37 & 15.25 & 6.38 & 21.80 & & & & & \\
\hline 1964 & 12.80 & 13.06 & 15.40 & 9.46 & 18.80 & 15.88 & & & & \\
\hline 1965 & 13.00 & 13.25 & 15.16 & 10.62 & 17.24 & 15.03 & 14.19 & & & \\
\hline 1966 & 10.10 & 9.90 & 10.88 & 6.56 & 10.28 & 6.69 & 2.37 & -8.23 & & \\
\hline 1967 & 11.81 & 11.85 & 12.99 & 9.65 & 13.34 & 11.32 & 9.84 & 7.74 & 26.48 & \\
\hline 1968 & 11.83 & 11.86 & 12.87 & 9.99 & 13.12 & 11.46 & 10.38 & 9.14 & 19.03 & 12.01 \\
\hline 1969 & 9.67 & 9.49 & 10.10 & 7.30 & 9.53 & 7.61 & 6.03 & 4.09 & 8.55 & 0.56 \\
\hline 1970 & 8.46 & 8.18 & 8.59 & 5.98 & 7.73 & 5.86 & 4.28 & 2.40 & 5.25 & -1.01 \\
\hline 1971 & 8.86 & 8.64 & 9.06 & 6.73 & 8.39 & 6.82 & 5.59 & 4.22 & 6.90 & 2.50 \\
\hline 1972 & 9.44 & 9.29 & 9.72 & 7.66 & 9.25 & 7.94 & 6.99 & 6.00 & 8.58 & 5.31 \\
\hline 1973 & 7.47 & 7.19 & 7.42 & 5.38 & 6.60 & 5.18 & 4.06 & 2.86 & 4.55 & 1.28 \\
\hline 1974 & 4.85 & 4.42 & 4.44 & 2.39 & 3.22 & 1.67 & 0.35 & -1.08 & -0.14 & -3.46 \\
\hline 1975 & 6.71 & 6.41 & 6.56 & 4.77 & 5.74 & 4.50 & 3.52 & 2.51 & 3.78 & 1.24 \\
\hline 1976 & 7.74 & 7.52 & 7.73 & 6.11 & 7.12 & 6.07 & 5.29 & 4.52 & 5.88 & 3.81 \\
\hline 1977 & 7.45 & 7.23 & 7.42 & 5.88 & 6.81 & 5.81 & 5.07 & 4.34 & 5.57 & 3.68 \\
\hline 1978 & 7.84 & 7.65 & 7.84 & 6.42 & 7.32 & 6.42 & 5.78 & 5.16 & 6.36 & 4.69 \\
\hline 1979 & 8.43 & 8.27 & 8.49 & 7.17 & 8.08 & 7.27 & 6.72 & 6.21 & 7.41 & 5.96 \\
\hline 1980 & 9.54 & 9.45 & 9.72 & 8.52 & 9.45 & 8.77 & 8.34 & 7.96 & 9.22 & 7.99 \\
\hline 1981 & 8.86 & 8.74 & 8.96 & 7.79 & 8.63 & 7.95 & 7.50 & 7.09 & 8.20 & 7.00 \\
\hline 1982 & 9.54 & 9.45 & 9.70 & 8.61 & 9.46 & 8.85 & 8.47 & 8.15 & 9.26 & 8.20 \\
\hline 1983 & 10.08 & 10.03 & 10.29 & 9.27 & 10.12 & 9.56 & 9.24 & 8.97 & 10.08 & 9.13 \\
\hline 1984 & 10.16 & 10.10 & 10.36 & 9.39 & 10.20 & 9.68 & 9.38 & 9.13 & 10.18 & $\begin{array}{l}9.10 \\
9.29\end{array}$ \\
\hline 1985 & 11.10 & 11.09 & 11.37 & 10.47 & 11.31 & 10.85 & 10.62 & 10.44 & 11.53 & $\begin{array}{r}7.29 \\
10.75\end{array}$ \\
\hline 1986 & 11.26 & 11.25 & 11.53 & 10.67 & 11.48 & 11.05 & 10.84 & 10.68 & 11.73 & $\begin{array}{l}10.15 \\
11.00\end{array}$ \\
\hline
\end{tabular}


TABLE 5-18 (Continued)

\begin{tabular}{|c|c|c|c|c|c|c|c|c|c|}
\hline $\begin{array}{l}\text { TO THE } \\
\text { END OF }\end{array}$ & $\begin{array}{l}\text { FROM } \\
1969\end{array}$ & $\begin{array}{c}\text { HE BEG } \\
1970\end{array}$ & $\begin{array}{l}\text { INING OF } \\
1971\end{array}$ & 1972 & 1973 & 1974 & 1975 & 1976 & 1977 \\
\hline 1969 & -9.72 & & & & & & & & \\
\hline 1970 & -6.94 & -4.07 & & & & & & & \\
\hline 1971 & -0.49 & 4.48 & 13.79 & & & & & & \\
\hline 1972 & 3.70 & 8.60 & 15.55 & 17.34 & & & & & \\
\hline 1973 & -0.74 & 1.64 & 3.62 & -1.12 & -16.67 & & & & \\
\hline 1974 & -5.82 & -5.02 & -5.26 & -10.87 & -22.32 & -27.58 & & & \\
\hline 1975 & -0.21 & 1.47 & 2.62 & 0.00 & -5.19 & 1.14 & 41.24 & & \\
\hline 1976 & 2.83 & 4.76 & 6.31 & 4.88 & 1.97 & 9.07 & 33.86 & 26.86 & \\
\hline 1977 & 2.79 & 4.47 & 5.75 & 4.47 & 2.07 & 7.39 & 22.45 & 14.02 & 2.48 \\
\hline 1978 & 3.99 & 5.64 & 6.92 & 5.97 & 4.18 & 8.94 & 20.65 & 14.48 & 8.75 \\
\hline 1979 & 5.42 & 7.07 & 8.38 & 7.73 & 6.42 & 10.85 & 20.70 & 16.05 & 12.65 \\
\hline 1980 & 7.67 & 9.40 & 10.85 & 10.53 & 9.71 & 14.10 & 23.09 & 19.74 & 18.03 \\
\hline 1981 & 6.62 & 8.11 & 9.29 & 8.86 & 7.95 & 11.50 & 18.59 & 15.19 & 12.99 \\
\hline 1982 & 7.93 & 9.43 & 10.63 & 10.35 & 9.68 & 13.07 & 19.55 & 16.74 & 15.13 \\
\hline 1983 & 8.94 & 10.41 & 11.61 & 11.43 & 10.91 & 14.12 & 20.04 & 17.62 & 16.36 \\
\hline 1984 & 9.13 & 10.51 & 11.64 & 11.47 & 11.00 & 13.93 & 19.21 & 16.98 & 15.80 \\
\hline 1985 & 10.68 & 12.09 & 13.26 & 13.23 & 12.92 & 15.81 & 20.86 & 18.99 & 18.15 \\
\hline 1986 & 10.94 & 12.30 & 13.41 & 13.38 & 13.10 & 15.79 & 20.41 & 18.68 & 17.89 \\
\hline
\end{tabular}

TO THE FROM THE BEGINNING OF

$\begin{array}{llllllllll}\text { END OF } & 1978 & 1979 & 1980 & 1981 & 1982 & 1983 & 1984 & 1985 & 1986\end{array}$

$\begin{array}{lrrrrrrrrr}1978 & 15.41 & & & & & & & & \\ 1979 & 18.11 & 20.86 & & & & & & & \\ 1980 & 23.72 & 28.10 & 35.76 & & & & & \\ 1981 & 15.78 & 15.90 & 13.49 & -5.12 & & & & \\ 1982 & 17.84 & 18.46 & 17.67 & 9.55 & 26.48 & & & \\ 1983 & 18.85 & 19.54 & 19.22 & 14.16 & 25.23 & 23.99 & & & \\ 1984 & 17.84 & 18.25 & 17.74 & 13.62 & 20.66 & 17.85 & 12.01 & & \\ 1985 & 20.27 & 20.98 & 21.00 & 18.24 & 24.93 & 24.42 & 24.64 & 38.69 & \\ 1986 & 19.74 & 20.29 & 20.21 & 17.80 & 23.00 & 22.15 & 21.54 & 26.61 & 15.58\end{array}$


TABLE 5-19

REAL U.S. CRSP EQUITIES (EXCHANGE RATE ADJUSTED): TOTAL RETURNS: RATES OF RETURN FOR VARIOUS HOLDING PERIODS FROM 1950 TO 1986

\begin{tabular}{|c|c|c|c|c|c|c|c|c|c|}
\hline $\begin{array}{l}\text { TO THE } \\
\text { END OF }\end{array}$ & $\begin{array}{l}\text { FROM } \\
1950\end{array}$ & $\underset{1951}{\text { HE BEG }_{195}}$ & $\begin{array}{l}\text { INING OF } \\
1952\end{array}$ & 1953 & 1954 & 1955 & 1956 & 1957 & 1958 \\
\hline 1950 & 16.93 & & & & & & & & \\
\hline 1951 & 11.49 & 6.30 & & & & & & & \\
\hline 1952 & 10.70 & 7.71 & 9.14 & & & & & & \\
\hline 1953 & 8.08 & 5.28 & 4.77 & 0.58 & & & & & \\
\hline 1954 & 15.24 & 14.82 & 17.81 & 22.40 & 48.96 & & & & \\
\hline 1955 & 17.41 & 17.51 & 20.49 & 24.54 & 38.58 & 28.92 & & & \\
\hline 1956 & 14.91 & 14.58 & 16.31 & 18.18 & 24.71 & 14.10 & 0.99 & & \\
\hline 1957 & 11.33 & 10.56 & 11.28 & 11.72 & 14.69 & 5.12 & -5.08 & -10.79 & \\
\hline 1958 & 14.13 & 13.79 & 14.90 & 15.89 & 19.22 & 12.76 & 7.84 & 11.44 & 39.21 \\
\hline 1959 & 13.72 & 13.37 & 14.29 & 15.04 & 17.65 & 12.22 & 8.40 & 10.99 & 23.80 \\
\hline 1960 & 12.69 & 12.27 & 12.96 & 13.44 & 15.41 & 10.61 & 7.27 & 8.90 & 16.38 \\
\hline 1961 & 14.39 & 14.16 & 14.97 & 15.64 & 17.68 & 13.78 & 11.43 & 13.65 & 20.74 \\
\hline 1962 & 12.44 & 12.07 & 12.61 & 12.96 & 14.43 & 10.72 & 8.34 & 9.61 & 14.22 \\
\hline 1963 & 12.93 & 12.63 & 13.17 & 13.55 & 14.93 & 11.67 & 9.68 & 10.98 & 15.10 \\
\hline 1964 & 12.99 & 12.71 & 13.22 & 13.57 & 14.83 & 11.88 & 10.13 & 11.33 & 14.91 \\
\hline 1965 & 12.86 & 12.59 & 13.05 & 13.36 & 14.50 & 11.79 & 10.21 & 11.28 & 14.40 \\
\hline 1966 & 11.27 & 10.92 & 11.24 & 11.39 & 12.27 & 9.65 & 8.05 & 8.78 & 11.21 \\
\hline 1967 & 11.81 & 11.51 & 11.85 & 12.03 & 12.90 & 10.51 & 9.10 & 9.87 & 12.19 \\
\hline 1968 & 11.58 & 11.30 & 11.60 & 11.75 & 12.54 & 10.31 & 8.99 & 9.69 & 11.77 \\
\hline 1969 & 10.16 & 9.81 & 10.01 & 10.06 & 10.69 & 8.51 & 7.19 & 7.68 & 9.38 \\
\hline 1970 & 9.36 & 8.99 & 9.14 & 9.14 & 9.66 & 7.58 & 6.29 & 6.68 & 8.16 \\
\hline 1971 & 9.32 & 8.97 & 9.11 & 9.10 & 9.60 & 7.64 & 6.43 & 6.80 & 8.19 \\
\hline 1972 & 9.42 & 9.09 & 9.22 & 9.23 & 9.70 & 7.86 & 6.73 & 7.10 & 8.41 \\
\hline 1973 & 7.79 & 7.40 & 7.46 & 7.38 & 7.73 & 5.91 & 4.76 & 4.98 & 6.05 \\
\hline 1974 & 5.59 & 5.15 & 5.10 & 4.92 & 5.13 & 3.31 & 2.11 & 2.18 & 2.99 \\
\hline 1975 & 6.41 & 6.01 & 5.99 & 5.86 & 6.11 & 4.41 & 3.31 & 3.44 & 4.29 \\
\hline 1976 & 6.88 & 6.51 & 6.51 & 6.41 & 6.67 & 5.06 & 4.04 & 4.20 & 5.05 \\
\hline 1977 & 6.37 & 6.00 & 5.99 & 5.86 & 6.09 & 4.54 & 3.54 & 3.67 & 4.45 \\
\hline 1978 & 6.38 & 6.02 & 6.01 & 5.89 & 6.11 & 4.62 & 3.67 & 3.79 & 4.55 \\
\hline 1979 & 6.50 & 6.15 & 6.15 & 6.04 & 6.26 & 4.83 & 3.93 & 4.06 & 4.79 \\
\hline 1980 & 6.97 & 6.65 & 6.66 & 6.58 & 6.80 & 5.45 & 4.60 & 4.76 & 5.49 \\
\hline 1981 & 6.19 & 5.86 & 5.84 & 5.73 & 5.92 & 4.59 & 3.75 & 3.87 & 4.53 \\
\hline 1982 & 6.47 & 6.15 & 6.15 & 6.05 & 6.25 & 4.97 & 4.18 & 4.30 & 4.95 \\
\hline 1983 & 6.80 & 6.51 & 6.52 & 6.43 & 6.64 & 5.41 & 4.66 & 4.80 & 5.45 \\
\hline 1984 & 6.84 & 6.55 & 6.56 & 6.48 & 6.68 & 5.50 & 4.77 & 4.91 & 5.54 \\
\hline 1985 & 7.49 & 7.23 & 7.26 & 7.20 & 7.41 & 6.29 & 5.60 & 5.77 & 6.41 \\
\hline 1986 & 7.58 & 7.33 & 7.36 & 7.31 & 7.52 & 6.43 & 5.77 & 5.94 & 6.57 \\
\hline
\end{tabular}


TABLE 5-19 (Continued)

\begin{tabular}{|c|c|c|c|c|c|c|c|c|c|c|}
\hline \multirow{2}{*}{$\begin{array}{l}\text { TO THE } \\
\text { END OF }\end{array}$} & \multicolumn{4}{|c|}{ FROM THE BEGINNING OF } & \multirow[b]{2}{*}{1963} & \multirow[b]{2}{*}{1964} & \multirow[b]{2}{*}{1965} & \multirow[b]{2}{*}{1966} & \multirow[b]{2}{*}{1967} & \multirow[b]{2}{*}{1968} \\
\hline & 1959 & 1960 & 1961 & 1962 & & & & & & \\
\hline 1959 & 10.09 & & & & & & & & & \\
\hline 1960 & 6.41 & 2.86 & & & & & & & & \\
\hline 1961 & 15.15 & 17.76 & 34.83 & & & & & & & \\
\hline 1962 & 8.71 & 8.26 & 11.06 & -8.52 & & & & & & \\
\hline 1963 & 10.80 & 10.98 & 13.83 & 4.59 & 19.58 & & & & & \\
\hline 1964 & 11.30 & 11.54 & 13.82 & 7.57 & 16.65 & 13.80 & & & & \\
\hline 1965 & 11.24 & 11.43 & 13.23 & 8.39 & 14.70 & 12.33 & 10.88 & & & \\
\hline 1966 & 8.13 & 7.85 & 8.71 & 4.13 & 7.55 & 3.82 & -0.84 & -11.32 & & \\
\hline 1967 & 9.53 & 9.46 & 10.43 & 6.82 & 10.19 & 7.96 & 6.08 & 3.75 & 21.38 & \\
\hline 1968 & 9.34 & 9.26 & 10.09 & 6.94 & 9.76 & 7.90 & 6.47 & 5.04 & 14.32 & 7.67 \\
\hline 1969 & 7.01 & 6.71 & 7.14 & 4.11 & 6.05 & 3.95 & 2.08 & 0.00 & 4.08 & -3.62 \\
\hline 1970 & 5.91 & 5.54 & 5.81 & 3.00 & 4.54 & 2.55 & 0.78 & -1.12 & 1.61 & -4.24 \\
\hline 1971 & 6.11 & 5.78 & 6.05 & 3.54 & 4.97 & 3.28 & 1.85 & 0.42 & 2.95 & -1.20 \\
\hline 1972 & 6.49 & 6.22 & 6.51 & 4.25 & 5.62 & 4.17 & 3.03 & 1.95 & 4.35 & 1.24 \\
\hline 1973 & 4.15 & 3.74 & 3.80 & 1.57 & 2.54 & 0.97 & -0.36 & -1.68 & -0.22 & -3.43 \\
\hline 1974 & 1.07 & 0.50 & 0.33 & -1.92 & -1.35 & -3.06 & -4.60 & -6.18 & -5.52 & -8.84 \\
\hline 1975 & 2.53 & 2.08 & 2.03 & 0.01 & 0.70 & -0.73 & -1.95 & -3.15 & -2.20 & -4.81 \\
\hline 1976 & 3.42 & 3.04 & 3.05 & 1.22 & 1.96 & 0.72 & -0.30 & -1.26 & -0.20 & -2.34 \\
\hline 1977 & 2.88 & 2.49 & 2.47 & 0.73 & 1.38 & 0.19 & -0.78 & -1.70 & -0.78 & -2.76 \\
\hline 1978 & 3.06 & 2.70 & 2.69 & 1.06 & 1.69 & 0.60 & -0.28 & -1.09 & -0.19 & -1.95 \\
\hline 1979 & 3.38 & 3.06 & 3.07 & 1.54 & 2.17 & 1.17 & 0.38 & -0.33 & 0.57 & -1.00 \\
\hline 1980 & 4.17 & 3.89 & 3.95 & 2.53 & 3.18 & 2.29 & 1.61 & 1.03 & 1.97 & 0.61 \\
\hline 1981 & 3.23 & 2.93 & 2.93 & 1.55 & 2.11 & 1.22 & 0.53 & -0.09 & 0.71 & -0.62 \\
\hline 1982 & 3.73 & 3.46 & 3.48 & 2.19 & 2.76 & 1.94 & 1.32 & 0.78 & 1.59 & 0.39 \\
\hline 1983 & 4.28 & 4.05 & 4.10 & 2.88 & 3.46 & 2.71 & 2.16 & 1.70 & 2.52 & 1.44 \\
\hline 1984 & 4.42 & 4.20 & 4.26 & 3.10 & 3.66 & 2.96 & 2.44 & 2.02 & 2.81 & 1.82 \\
\hline 1985 & 5.36 & 5.18 & 5.28 & 4.20 & 4.79 & 4.16 & 3.72 & 3.38 & 4.21 & 3.33 \\
\hline 1986 & 5.55 & 5.39 & 5.49 & 4.46 & 5.04 & 4.45 & 4.04 & 3.72 & 4.54 & 3.72 \\
\hline
\end{tabular}




\section{TABLE 5-19 (Continued)}

\begin{tabular}{|c|c|c|c|c|c|c|c|c|c|}
\hline TO THE & FROM & THE BEC & NNING OF & & & & & & \\
\hline & & 1970 & 1971 & 1972 & 1973 & 1974 & 1975 & 1976 & 1977 \\
\hline 1969 & -13.73 & & & & & & & & \\
\hline 1970 & -9.69 & -5.47 & & & & & & & \\
\hline 1971 & -4.00 & 1.28 & 8.51 & & & & & & \\
\hline 1972 & -0.30 & 4.62 & 10.06 & 11.64 & & & & & \\
\hline 1973 & -5.51 & -3.33 & -2.61 & -7.73 & -23.74 & & & & \\
\hline 1974 & -11.34 & -10.85 & -12.15 & -18.12 & -29.88 & -35.52 & & & \\
\hline 1975 & -6.47 & -5.20 & -5.14 & -8.28 & -14.09 & -8.82 & 28.95 & & \\
\hline 1976 & -3.53 & -1.98 & -1.38 & -3.25 & -6.65 & -0.14 & 24.28 & 19.78 & \\
\hline 1977 & -3.85 & -2.54 & -2.11 & -3.78 & -6.59 & -1.74 & 13.08 & 5.90 & -6.37 \\
\hline 1978 & -2.86 & -1.57 & -1.07 & -2.37 & -4.53 & -0.14 & 11.40 & 6.10 & -0.14 \\
\hline 1979 & -1.75 & -0.46 & 0.11 & -0.90 & -2.57 & 1.49 & 11.14 & 7.08 & 3.15 \\
\hline 1980 & 0.04 & 1.40 & 2.12 & 1.43 & 0.22 & 4.21 & 12.89 & 9.93 & 7.60 \\
\hline 1981 & -1.23 & -0.11 & 0.39 & -0.39 & -1.64 & 1.53 & 8.34 & 5.24 & 2.55 \\
\hline 1982 & -0.11 & 1.03 & 1.59 & 0.98 & -0.03 & 3.02 & 9.24 & 6.68 & 4.64 \\
\hline 1983 & 1.04 & 2.19 & 2.80 & 2.34 & 1.54 & 4.49 & 10.24 & 8.10 & 6.53 \\
\hline 1984 & 1.46 & 2.56 & 3.16 & 2.76 & 2.06 & 4.80 & 10.01 & 8.09 & 6.71 \\
\hline 1985 & 3.08 & 4.24 & 4.92 & 4.67 & 4.15 & 6.89 & 11.92 & 10.34 & 9.34 \\
\hline 1986 & 3.51 & 4.62 & 5.29 & 5.08 & 4.62 & 7.20 & 11.84 & 10.40 & 9.50 \\
\hline
\end{tabular}

\section{TO THE FROM THE BEGINNING OF}

$\begin{array}{lrrrrrrrrr}\text { END OF } & \mathbf{1 9 7 8} & \mathbf{1 9 7 9} & \mathbf{1 9 8 0} & \mathbf{1 9 8 1} & \mathbf{1 9 8 2} & \mathbf{1 9 8 3} & \mathbf{1 9 8 4} & \mathbf{1 9 8 5} & \mathbf{1 9 8 6} \\ 1978 & 6.51 & & & & & & & & \\ 1979 & 8.28 & 10.07 & & & & & & & \\ 1980 & 12.70 & 15.93 & 22.10 & & & & & & \\ 1981 & 4.91 & 4.39 & 1.66 & -15.36 & & & & & \\ 1982 & 7.00 & 7.12 & 6.15 & -1.02 & 15.76 & & & & \\ 1983 & 8.85 & 9.32 & 9.14 & 5.13 & 17.17 & 18.60 & & & \\ 1984 & 8.72 & 9.09 & 8.90 & 5.83 & 14.01 & 13.15 & 7.95 & & \\ 1985 & 11.49 & 12.21 & 12.58 & 10.76 & 18.47 & 19.39 & 19.78 & 32.91 & \\ 1986 & 11.43 & 12.06 & 12.34 & 10.79 & 16.92 & 17.22 & 16.76 & 21.43 & 10.95\end{array}$




\section{TABLE 5-20}

\section{STATISTICAL CHARACTERISTICS OF BASIC MONTHLY RETURN SERIES FOR THE PERIOD 1950 TO 1987}

\begin{tabular}{|c|c|c|c|c|c|c|c|}
\hline & $\underline{\text { Kurtosis }}$ & High & $\underline{\text { Low }}$ & Mean & $\begin{array}{l}\text { Standard } \\
\text { Deviation }\end{array}$ & $\begin{array}{l}\text { Coefficient } \\
\text { of } \\
\text { Variation }\end{array}$ & Skewness \\
\hline $\begin{array}{l}\text { Consumer Price } \\
\text { Index }\end{array}$ & 0.2814 & 0.0196 & -0.0071 & 0.0038 & 0.0044 & 1.1579 & 0.3859 \\
\hline Treasury Bills & 1.8390 & 0.0191 & -0.0008 & 0.0048 & 0.0034 & 0.7083 & 1.1561 \\
\hline Long Canada Bonds & 7.1065 & 0.1617 & -0.0996 & 0.0045 & 0.0239 & 5.3111 & 0.8826 \\
\hline Provincial Bonds & 5.8066 & 0.1303 & -0.1193 & 0.0050 & 0.0243 & 4.8600 & 0.5853 \\
\hline Municipal Bonds & 4.4306 & 0.1196 & -0.0954 & 0.0053 & 0.0225 & 4.2453 & 0.6426 \\
\hline Industrial Bonds & 16.9376 & 0.2016 & -0.1163 & 0.0053 & 0.0229 & 4.3208 & 1.6473 \\
\hline Equities & 2.4091 & 0.1817 & -0.2149 & 0.0098 & 0.0449 & 4.5816 & -0.4793 \\
\hline
\end{tabular}


TABLE 5-21

\section{STATISTICAL CHARACTERISTICS OF CANADIAN AND U.S. MONTHLY RETURN SERIES 1950 TO 1986}

Series

Canadian

Equities

Federal Bonds

Industrial Bonds

Treasury Bills

C.P.I.

U.S. (Ibbotson-Sinquefield)

Equities

Treasury Bonds

Corporate Bonds

Treasury Bills

C.P.I.
Arithmetic Standard

Mean Deviation

High

Low

$\begin{array}{llll}0.0101 & 0.0436 & 0.1807 & -0.1820 \\ 0.0046 & 0.0235 & 0.1617 & -0.0996 \\ 0.0053 & 0.0229 & 0.2016 & -0.1163 \\ 0.0047 & 0.0034 & 0.0191 & -0.0008 \\ 0.0038 & 0.0044 & 0.0196 & -0.0071\end{array}$

0.0109

0.0399

0.1618

$-0.1112$

0.0045

0.0272

0.0257

0.1647

$-0.0787$

0.0050

0.1541

$-0.0812$

0.0047

0.0434

$-0.0434$

0.0040

0.0089

0.0461

$-0.0393$

U.S. (CRSP)

Equities

0.0108

0.0403

0.1644

$-0.1181$ Note: U.S. returns for all series are adjusted to reflect monthly changes in the exchange rate be-
tween Canadian and U.S. currency. 


\section{TABLE 5-22}

\section{U.S. MONTHLY RETURN SERIES (IBBOTSON AND SINQUEFIELD) EXCHANGE RATE ADJUSTED AND NOT EXCHANGE RATE ADJUSTED \\ 1950 TO 1986}

\section{Arithmetic Mean}

$\begin{array}{lllll}\text { Series } & \begin{array}{c}\text { Exchange } \\ \text { Adjusted }\end{array} & \begin{array}{c}\text { Not } \\ \text { Exchange } \\ \text { Adjusted }\end{array} & \begin{array}{c}\text { Exchange } \\ \text { Adjusted }\end{array} & \begin{array}{c}\text { Not } \\ \text { Exchange } \\ \text { Adjusted }\end{array} \\ \text { Equities } & 0.0109 & 0.0104 & 0.0399 & 0.0398 \\ \text { Treasury Bonds } & 0.0045 & 0.0040 & 0.0272 & 0.0262 \\ \text { Corporate Bonds } & 0.0050 & 0.0045 & 0.0257 & 0.0244 \\ \text { Treasury Bills } & 0.0047 & 0.0041 & 0.0087 & 0.0027 \\ \text { CPI } & 0.0040 & 0.0035 & 0.0089 & 0.0036\end{array}$




\section{TABLE 5-23}

\section{CORRELATIONS OF BASIC MONTHLY RETURN SERIES FOR THE PERIOD 1950 TO 1987}

\begin{tabular}{|c|c|c|c|c|c|c|c|}
\hline & $\begin{array}{l}\text { Consumer } \\
\text { Price } \\
\text { Index } \\
\end{array}$ & $\begin{array}{c}\text { Treasury } \\
\text { Bills } \\
\end{array}$ & $\begin{array}{l}\text { Canada } \\
\text { Bonds } \\
\end{array}$ & $\begin{array}{c}\text { Provincial } \\
\text { Bonds }\end{array}$ & $\begin{array}{c}\text { Municipal } \\
\text { Bonds }\end{array}$ & $\begin{array}{c}\text { Industrial } \\
\text { Bonds }\end{array}$ & Equity \\
\hline $\begin{array}{l}\text { Consumer } \\
\text { Price Index }\end{array}$ & 1.000 & & & & & & \\
\hline $\begin{array}{l}\text { Treasury } \\
\text { Bills }\end{array}$ & 0.366 & 1.000 & & & & & \\
\hline $\begin{array}{l}\text { Long Canada } \\
\text { Bonds }\end{array}$ & -0.030 & 0.276 & 1.000 & & & & \\
\hline $\begin{array}{l}\text { Provincial } \\
\text { Bonds }\end{array}$ & -0.061 & 0.262 & 0.914 & 1.000 & & & \\
\hline $\begin{array}{l}\text { Municipal } \\
\text { Bonds }\end{array}$ & -0.069 & 0.275 & 0.890 & 0.948 & 1.000 & & \\
\hline $\begin{array}{l}\text { Industrial } \\
\text { Bonds }\end{array}$ & -0.040 & 0.241 & 0.792 & 0.850 & 0.866 & 1.000 & \\
\hline Equities & -0.042 & 0.030 & 0.265 & 0.263 & 0.269 & 0.270 & 1.000 \\
\hline
\end{tabular}




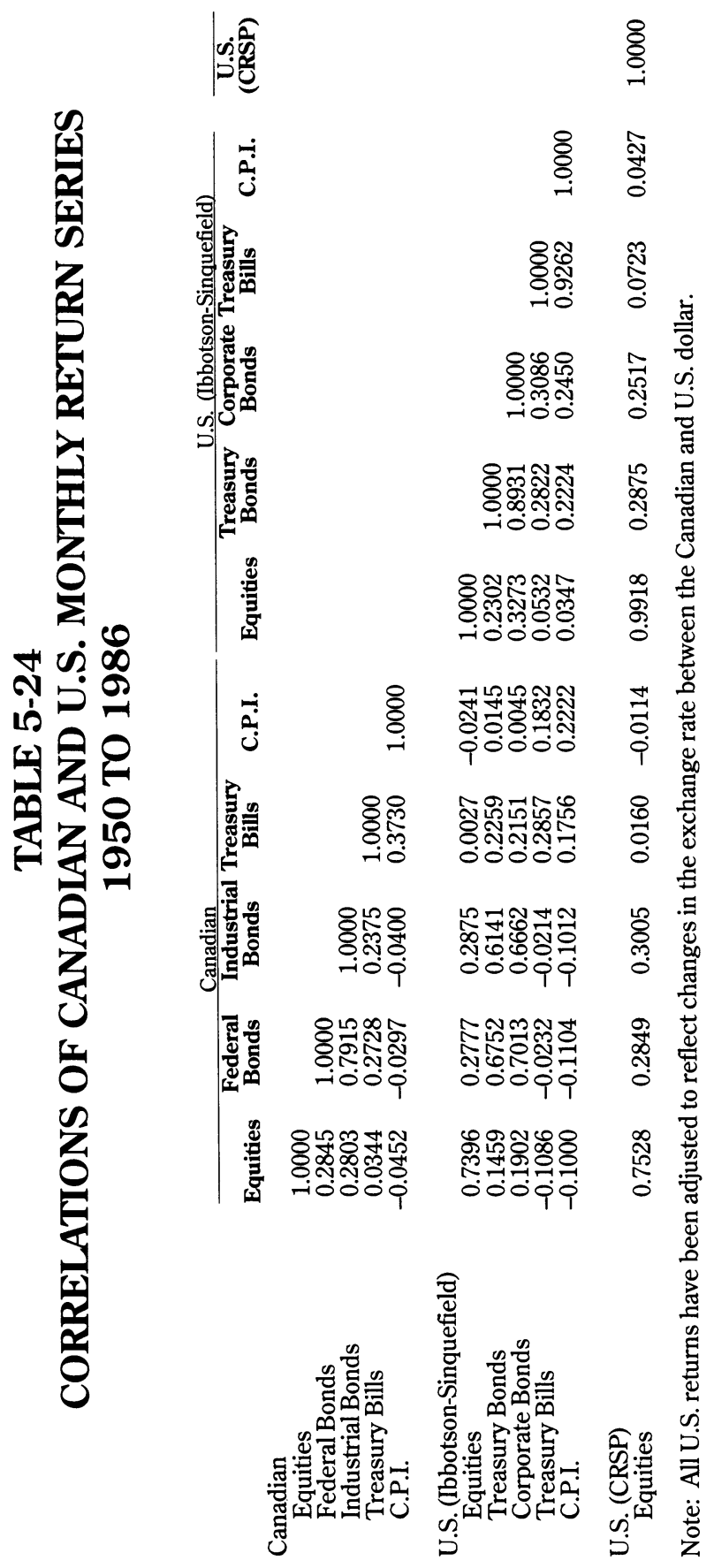




\section{TABLE 5-25}

\section{CORRELATIONS OF CANADIAN RETURNS IN MONTH $\mathrm{t}$ WITH U.S. (IBBOTSON AND SINQUEFIELD) RETURNS IN MONTH $\mathrm{t}+\mathbf{1}$, BASED ON THE PERIOD 1950 TO 1986}

$\begin{array}{lccccc} & \begin{array}{c}\text { Canadian } \\ \text { Equity }\end{array} & \begin{array}{c}\text { Canadian } \\ \text { Government }\end{array} & \begin{array}{c}\text { Canadian } \\ \text { Corporation }\end{array} & \begin{array}{c}\text { Canadian } \\ \text { Bills }\end{array} & \begin{array}{c}\text { Canadian } \\ \text { Inflation }\end{array} \\ \text { U.S. Equity } & -0.0127 & 0.0901 & 0.0616 & -0.0048 & -0.0241 \\ \text { U.S. Government } & -0.2533 & 0.0533 & 0.0072 & 0.1473 & 0.0145 \\ \text { U.S. Corporation } & -0.2094 & 0.1198 & 0.0524 & 0.1536 & 0.0045 \\ \text { U.S. Bills } & -0.0748 & 0.0877 & -0.1082 & 0.3049 & 0.1832 \\ \text { U.S. Inflation } & -0.0438 & -0.1427 & -0.1530 & 0.2008 & 0.2222\end{array}$

Note: All U.S. returns have been adjusted to reflect changes in the exchange rate between the Canadian and U.S. dollar. 


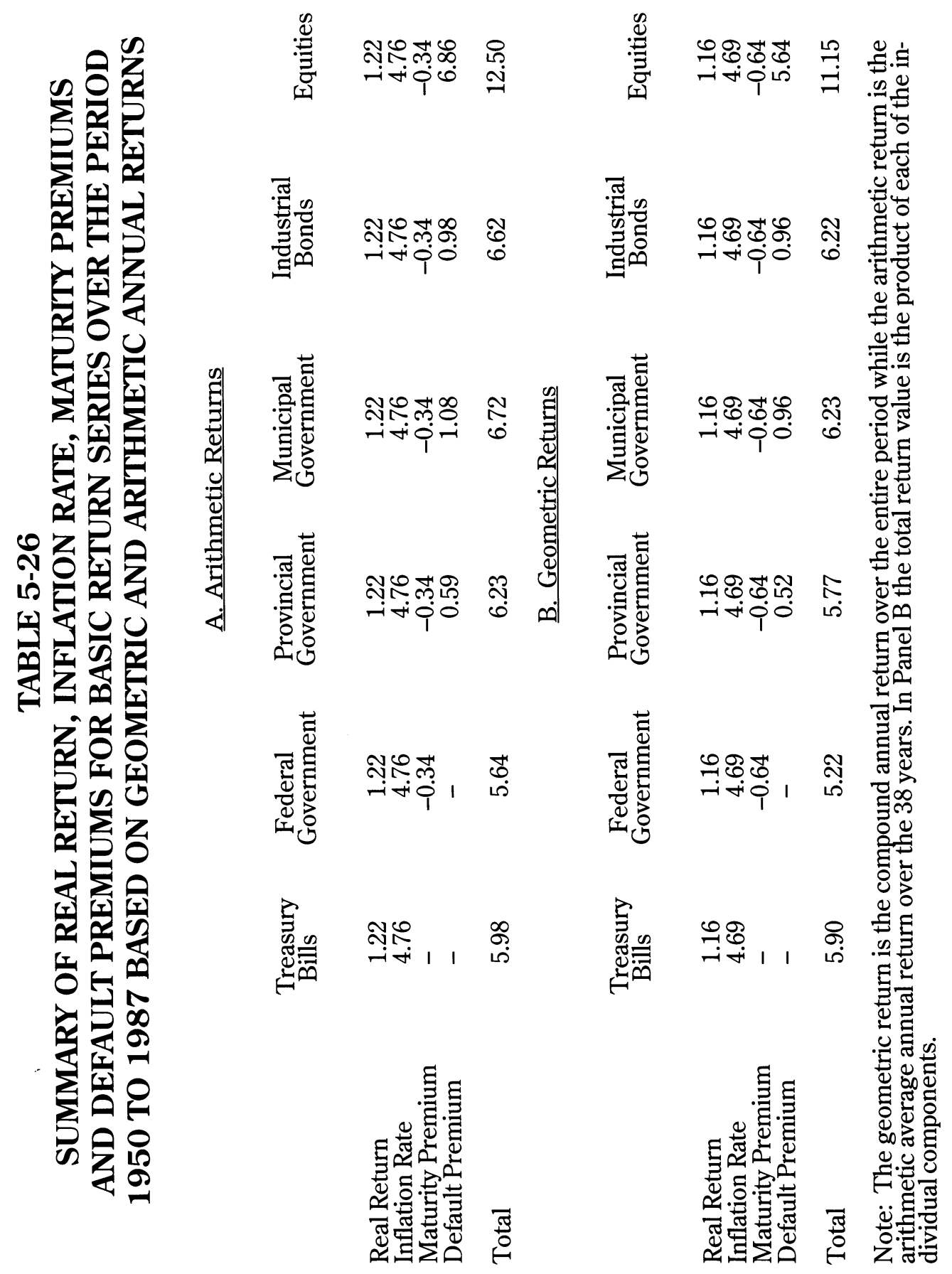




\section{TABLE 5-27}

\section{ARITHMETIC AVERAGE ANNUAL RETURN PREMIUMS 1950 TO 1986}

$\begin{array}{lcc} & \text { Canada } & \underline{\text { U.S. }}^{\mathbf{a}} \\ \text { Real Return } & 1.15 & 0.84 \\ \text { Inflation Rate } & 4.77 & 5.01 \\ \text { Maturity Premium } & -0.14 & -0.11 \\ \text { Industrial/Corporate Risk Premium } & 0.85 & 0.64 \\ \text { Equity Risk Premium } & 7.14 & 8.46\end{array}$

a. All U.S. returns have been adjusted to reflect changes in the value of the Canadian dollar. 
TABLE 5-28

\section{MOVING STANDARD DEVIATION OF EQUITY RETURNS 12-MONTH PERIODS 1950 TO 1987}

\begin{tabular}{c} 
12 Months \\
Ending \\
\hline DECEMBER 1950 \\
DECEMBER 1951 \\
DECEMBER 1952 \\
DECEMBER 1953 \\
DECEMBER 1954 \\
DECEMBER 1955 \\
DECEMBER 1956 \\
DECEMBER 1957 \\
DECEMBER 1958 \\
DECEMBER 1959 \\
DECEMBER 1960 \\
DECEMBER 1961 \\
DECEMBER 1962 \\
DECEMBER 1963 \\
DECEMBER 1964 \\
DECEMBER 1965 \\
DECEMBER 1966 \\
DECEMBER 1967 \\
DECEMBER 1968 \\
DECEMBER 1969 \\
DECEMBER 1970 \\
DECEMBER 1971 \\
DECEMBER 1972 \\
DECEMBER 1973 \\
DECEMBER 1974 \\
DECEMBER 1975 \\
DECEMBER 1976 \\
DECEMBER 1977 \\
DECEMBER 1978 \\
DECEMBER 1979
\end{tabular}

\begin{tabular}{c}
$\begin{array}{c}\text { Canadian } \\
\text { Monthly Standard } \\
\text { Deviation }\end{array}$ \\
\hline 0.038 \\
0.048 \\
0.033 \\
0.027 \\
0.024 \\
0.033 \\
0.049 \\
0.049 \\
0.021 \\
0.029 \\
0.038 \\
0.018 \\
0.039 \\
0.029 \\
0.018 \\
0.028 \\
0.029 \\
0.033 \\
0.040 \\
0.051 \\
0.053 \\
0.040 \\
0.034 \\
0.045 \\
0.061 \\
0.061 \\
0.050 \\
0.032 \\
0.041 \\
0.057 \\
\end{tabular}

U.S. Monthly Standard Deviation

Ibbotson

-Sinquefield $^{\mathbf{a}}$

CRSP $^{a}$

0.037

0.038

0.034

0.034

0.037

0.037

0.027

0.025

0.039

0.035

0.035

0.028

0.043

0.040

0.034

0.033

0.021

0.021

0.024

0.023

0.040

0.028

0.039

0.028

0.054

0.055

0.029

0.012

0.023

0.032

0.035

0.036

0.037

0.060

0.028

0.012

0.024

0.033

0.034

0.038

0.040

0.063

0.039

0.040

0.022

0.046

0.066

0.057

0.055

0.044

0.029

0.051

0.049

0.042 


\section{TABLE 5-28 (Continued)}

12 Months

Ending

DECEMBER 1980

DECEMBER 1981

DECEMBER 1982

DECEMBER 1983

DECEMBER 1984

DECEMBER 1985

DECEMBER 1986

DECEMBER 1987
Canadian

Monthly Standard Deviation

0.080

0.063

0.072

0.041

0.043

0.034

0.031

0.082
U.S. Monthly Standard Deviation

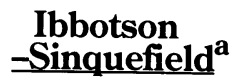

0.052

0.038

0.047

0.029

0.036

0.038

0.053

N/A
CRSP $^{\mathbf{a}}$

0.054

0.040

0.048

0.029

0.036

0.038

0.052

N/A

a. All U.S. data are adjusted for changes in the Canadian exchange rate. 
TABLE 5-29

\section{SUMMARY MONTHLY RETURN STATISTICS FOR THE LARGE FIRM AND SMALL FIRM PORTFOLIOS USING VALUE AND EQUAL WEIGHTING 1950 TO 1987}

\begin{tabular}{|c|c|c|c|c|c|c|}
\hline & \multicolumn{3}{|c|}{ A. Value Weighted } & \multicolumn{3}{|c|}{ B. Equal Weighted } \\
\hline & $\begin{array}{l}\text { All } \\
\text { Equity }\end{array}$ & $\begin{array}{l}\text { Large } \\
\text { Firm }\end{array}$ & $\begin{array}{l}\text { Small } \\
\text { Firm }\end{array}$ & $\begin{array}{c}\text { All } \\
\text { Equity }\end{array}$ & $\begin{array}{l}\text { Large } \\
\text { Firm }\end{array}$ & $\begin{array}{l}\text { Small } \\
\text { Firm } \\
\end{array}$ \\
\hline Minimum Observation & -0.1673 & -0.1852 & -0.1699 & -0.1839 & -0.1606 & -0.1752 \\
\hline Maximum Observation & 0.2755 & 0.1752 & 0.3067 & 0.1814 & 0.2040 & 0.3471 \\
\hline Mean & 0.0138 & 0.0098 & 0.0130 & 0.0098 & 0.0107 & 0.0169 \\
\hline Standard Deviation & 0.0481 & 0.0445 & 0.0505 & 0.0445 & 0.0447 & 0.0540 \\
\hline Coefficient of Variation & 3.4855 & 4.5408 & 3.8846 & 4.5408 & 4.1776 & 3.1953 \\
\hline Coefficient of Skewness & -0.1470 & -0.3863 & -0.0971 & -0.4456 & -0.4344 & 0.4022 \\
\hline Coefficient of Kurtosis & 3.6000 & 1.8628 & 4.6947 & 2.1674 & 2.1501 & 4.9110 \\
\hline
\end{tabular}


TABLE 5-30

SMALL CANADIAN EQUITIES: (VALUE WEIGHTED) TOTAL RETURNS RATES OF RETURN FOR VARIOUS HOLDING PERIODS FROM 1950 TO 1987

\begin{tabular}{|c|c|c|c|c|c|c|c|c|c|}
\hline $\begin{array}{l}\text { TO THE } \\
\text { END OF }\end{array}$ & $\begin{array}{l}\text { FROM } \\
1950\end{array}$ & $\underset{1951}{H E ~ B E G}$ & $\begin{array}{l}\text { NNING OF } \\
1952\end{array}$ & 1953 & 1954 & 1955 & 1956 & 1957 & 1958 \\
\hline 1950 & 13.71 & & & & & & & & \\
\hline 1951 & 22.71 & 32.42 & & & & & & & \\
\hline 1952 & 20.00 & 23.27 & 14.76 & & & & & & \\
\hline 1953 & 13.47 & 13.39 & 4.93 & -4.05 & & & & & \\
\hline 1954 & 18.64 & 19.90 & 16.00 & 16.62 & 41.75 & & & & \\
\hline 1955 & 20.59 & 22.02 & 19.55 & 21.19 & 36.20 & 30.87 & & & \\
\hline 1956 & 17.24 & 17.84 & 15.13 & 15.22 & 22.47 & 13.83 & -0.99 & & \\
\hline 1957 & 11.58 & 11.28 & 8.10 & 6.82 & 9.72 & 0.74 & -11.61 & -21.10 & \\
\hline 1958 & 14.09 & 14.13 & 11.74 & 11.24 & 14.58 & 8.64 & 2.11 & 3.69 & 36.26 \\
\hline 1959 & 11.82 & 11.61 & 9.25 & 8.49 & 10.73 & 5.39 & -0.16 & 0.12 & 12.78 \\
\hline 1960 & 10.42 & 10.10 & 7.87 & 7.03 & 8.72 & 4.01 & -0.65 & -0.57 & 7.39 \\
\hline 1961 & 12.98 & 12.92 & 11.13 & 10.74 & 12.74 & 9.11 & 5.85 & 7.28 & 15.84 \\
\hline 1962 & 11.30 & 11.10 & 9.34 & 8.81 & 10.34 & 6.94 & 3.90 & 4.74 & 10.84 \\
\hline 1963 & 11.60 & 11.44 & 9.84 & 9.41 & 10.85 & 7.87 & 5.29 & 6.22 & 11.62 \\
\hline 1964 & 13.22 & 13.18 & 11.82 & 11.58 & 13.12 & 10.60 & 8.55 & 9.81 & 15.12 \\
\hline 1965 & 13.72 & 13.72 & 12.49 & 12.31 & 13.80 & 11.55 & 9.78 & 11.05 & 15.89 \\
\hline 1966 & 12.80 & 12.74 & 11.54 & 11.32 & 12.59 & 10.45 & 8.76 & 9.79 & 13.90 \\
\hline 1967 & 14.03 & 14.04 & 12.98 & 12.87 & 14.18 & 12.30 & 10.88 & 12.02 & 16.02 \\
\hline 1968 & 16.47 & 16.62 & 15.75 & 15.82 & 17.28 & 15.70 & 14.61 & 16.01 & 20.15 \\
\hline 1969 & 15.34 & 15.42 & 14.54 & 14.53 & 15.81 & 14.25 & 13.15 & 14.32 & 17.91 \\
\hline 1970 & 13.67 & 13.66 & 12.75 & 12.64 & 13.71 & 12.15 & 11.01 & 11.92 & 14.97 \\
\hline 1971 & 14.05 & 14.06 & 13.21 & 13.13 & 14.17 & 12.73 & 11.68 & 12.58 & 15.48 \\
\hline 1972 & 15.53 & 15.61 & 14.87 & 14.87 & 15.97 & 14.68 & 13.79 & 14.79 & 17.69 \\
\hline 1973 & 14.71 & 14.76 & 14.01 & 13.98 & 14.96 & 13.70 & 12.82 & 13.69 & 16.31 \\
\hline 1974 & 12.53 & 12.48 & 11.68 & 11.55 & 12.35 & 11.05 & 10.09 & 10.75 & 12.98 \\
\hline 1975 & 13.63 & 13.62 & 12.90 & 12.82 & 13.65 & 12.46 & 11.61 & 12.32 & 14.55 \\
\hline 1976 & 13.74 & 13.75 & 13.06 & 12.99 & 13.79 & 12.66 & 11.86 & 12.54 & 14.67 \\
\hline 1977 & 14.63 & 14.67 & 14.04 & 14.01 & 14.83 & 13.78 & 13.06 & 13.78 & 15.88 \\
\hline 1978 & 15.57 & 15.64 & 15.06 & 15.07 & 15.91 & 14.95 & 14.30 & 15.05 & 17.13 \\
\hline 1979 & 16.66 & 16.77 & 16.24 & 16.30 & 17.16 & 16.27 & 15.70 & 16.49 & 18.57 \\
\hline 1980 & 17.91 & 18.05 & 17.58 & 17.68 & 18.58 & 17.77 & 17.27 & 18.10 & 20.19 \\
\hline 1981 & 16.15 & 16.23 & 15.72 & 15.76 & 16.53 & 15.69 & 15.14 & 15.84 & 17.71 \\
\hline 1982 & 15.84 & 15.91 & 15.41 & 15.44 & 16.17 & 15.35 & 14.81 & 15.47 & 17.24 \\
\hline 1983 & 16.33 & 16.41 & 15.94 & 15.98 & 16.71 & 15.94 & 15.43 & 16.09 & 17.83 \\
\hline 1984 & 15.51 & 15.57 & 15.09 & 15.10 & 15.78 & 15.00 & 14.49 & 15.08 & 16.70 \\
\hline 1985 & 15.93 & 16.00 & 15.55 & 15.57 & 16.24 & 15.50 & 15.02 & 15.62 & 17.21 \\
\hline 1986 & 15.76 & 15.81 & 15.37 & 15.39 & 16.04 & 15.31 & 14.84 & 15.41 & 16.93 \\
\hline 1987 & 15.08 & 15.11 & 14.67 & 14.66 & 15.27 & 14.55 & 14.07 & 14.59 & 16.03 \\
\hline
\end{tabular}




\section{TABLE 5-30 (Continued)}

\begin{tabular}{|c|c|c|c|c|c|c|c|c|c|c|}
\hline TO THE & & INE & SINNIN & OF & & & & & & \\
\hline END OF & 1959 & 1960 & 1961 & 1962 & 1963 & 1964 & 1965 & 1966 & 1967 & 1968 \\
\hline 1959 & -6.65 & & & & & & & & & \\
\hline 1960 & -4.66 & -2.62 & & & & & & & & \\
\hline 1961 & 9.74 & 18.99 & 45.39 & & & & & & & \\
\hline 1962 & 5.27 & 9.57 & 16.22 & -7.09 & & & & & & \\
\hline 1963 & 7.25 & 11.04 & 16.00 & 3.62 & 15.57 & & & & & \\
\hline 1964 & 11.93 & 16.06 & 21.27 & 14.16 & 26.54 & 38.55 & & & & \\
\hline 1965 & 13.24 & 16.95 & 21.31 & 15.94 & 24.83 & 29.74 & 21.48 & & & \\
\hline 1966 & 11.37 & 14.22 & 17.29 & 12.36 & 17.83 & 18.60 & 9.73 & -0.89 & & \\
\hline 1967 & 13.97 & 16.84 & 19.92 & 16.14 & 21.44 & 22.95 & 18.15 & 16.52 & 37.01 & \\
\hline 1968 & 18.65 & 21.86 & 25.32 & 22.69 & 28.51 & 31.26 & 29.50 & 32.29 & 52.84 & 70.51 \\
\hline 1969 & 16.37 & 18.96 & 21.64 & 18.95 & 23.23 & 24.55 & 21.93 & 22.04 & 30.81 & 27.82 \\
\hline 1970 & 13.35 & 15.37 & 17.34 & 14.58 & 17.62 & 17.92 & 14.79 & 13.50 & 17.41 & 11.53 \\
\hline 1971 & 14.02 & 15.93 & 17.79 & 15.33 & 18.14 & 18.46 & 15.84 & 14.93 & 18.38 & 14.14 \\
\hline 1972 & 16.47 & 18.47 & 20.42 & 18.37 & 21.28 & 21.93 & 20.00 & 19.79 & 23.63 & 21.12 \\
\hline 1973 & 15.09 & 16.82 & 18.47 & 16.47 & 18.88 & 19.22 & 17.25 & 16.73 & 19.49 & 16.80 \\
\hline 1974 & 11.66 & 13.00 & 14.21 & 12.11 & 13.88 & 13.73 & 11.50 & 10.44 & 11.95 & 8.77 \\
\hline 1975 & 13.38 & 14.77 & 16.03 & 14.18 & 16.00 & 16.04 & 14.18 & 13.48 & 15.20 & 12.73 \\
\hline 1976 & 13.57 & 14.89 & 16.08 & 14.36 & 16.06 & 16.10 & 14.41 & 13.78 & 15.37 & 13.18 \\
\hline 1977 & 14.90 & 16.23 & 17.44 & 15.89 & 17.61 & 17.76 & 16.29 & 15.87 & 17.53 & 15.74 \\
\hline 1978 & 16.25 & 17.60 & 18.84 & 17.44 & 19.17 & 19.41 & 18.15 & 17.90 & 19.62 & 18.15 \\
\hline 1979 & 17.79 & 19.16 & 20.44 & 19.18 & 20.94 & 21.28 & 20.21 & 20.12 & 21.91 & 20.73 \\
\hline 1980 & 19.51 & 20.92 & 22.24 & 21.13 & 22.92 & 23.37 & 22.48 & 22.55 & 24.42 & 23.50 \\
\hline 1981 & 16.96 & 18.17 & 19.26 & 18.09 & 19.59 & 19.81 & 18.80 & 18.63 & 20.06 & 18.93 \\
\hline 1982 & 16.51 & 17.64 & 18.65 & 17.51 & 18.90 & 19.08 & 18.08 & 17.88 & 19.17 & 18.06 \\
\hline 1983 & 17.15 & 18.26 & 19.26 & 18.19 & 19.56 & 19.76 & 18.85 & 18.70 & 19.97 & 18.98 \\
\hline 1984 & 16.01 & 17.02 & 17.92 & 16.85 & 18.08 & 18.20 & 17.26 & 17.05 & 18.13 & 17.11 \\
\hline 1985 & 16.56 & 17.56 & 18.44 & 17.44 & 18.64 & 18.78 & 17.91 & 17.74 & 18.81 & 17.87 \\
\hline 1986 & 16.30 & 17.25 & 18.09 & 17.11 & 18.25 & 18.36 & 17.52 & 17.33 & 18.33 & 17.42 \\
\hline 1987 & 15.39 & 16.26 & 17.03 & 16.06 & 17.09 & 17.16 & 16.31 & 16.08 & 16.95 & 16.03 \\
\hline
\end{tabular}




\section{TABLE 5-30 (Continued)}

\begin{tabular}{|c|c|c|c|c|c|c|c|c|c|}
\hline $\begin{array}{l}\text { TO THE } \\
\text { END OF }\end{array}$ & $\begin{array}{l}\text { FROM } \\
1969\end{array}$ & $\underset{1970}{\text { THE BEG }}$ & $\begin{array}{l}\text { JNING OF } \\
1971\end{array}$ & 1972 & 1973 & 1974 & 1975 & 1976 & 1977 \\
\hline 1969 & -4.18 & & & & & & & & \\
\hline 1970 & -9.80 & -15.09 & & & & & & & \\
\hline 1971 & -0.16 & 1.92 & 22.33 & & & & & & \\
\hline 1972 & 11.19 & 16.84 & 37.06 & 53.57 & & & & & \\
\hline 1973 & 8.29 & 11.65 & 22.32 & 22.31 & -2.59 & & & & \\
\hline 1974 & 0.91 & 1.97 & 6.74 & 2.00 & -16.87 & -29.06 & & & \\
\hline 1975 & 6.26 & 8.11 & 13.45 & 11.34 & 0.02 & 1.35 & 44.81 & & \\
\hline 1976 & 7.53 & 9.32 & 14.02 & 12.43 & 3.99 & 6.28 & 30.10 & 16.88 & \\
\hline 1977 & 10.86 & 12.90 & 17.59 & 16.82 & 10.60 & 14.17 & 33.80 & 28.61 & 41.51 \\
\hline 1978 & 13.90 & 16.10 & 20.74 & 20.51 & 15.74 & 19.80 & 36.56 & 33.92 & 43.35 \\
\hline 1979 & 17.00 & 19.36 & 23.97 & 24.17 & 20.46 & 24.80 & 39.73 & 38.49 & 46.55 \\
\hline 1980 & 20.22 & 22.73 & 27.33 & 27.90 & 25.01 & 29.55 & 43.23 & 42.91 & 50.28 \\
\hline 1981 & 15.68 & 17.51 & 21.04 & 20.91 & 17.74 & 20.56 & 30.05 & 27.74 & 30.03 \\
\hline 1982 & 15.00 & 16.63 & 19.75 & 19.52 & 16.56 & 18.91 & 26.84 & 24.47 & 25.78 \\
\hline 1983 & 16.15 & 17.76 & 20.76 & 20.63 & 18.01 & 20.30 & 27.57 & 25.57 & 26.86 \\
\hline 1984 & 14.39 & 15.75 & 18.34 & 18.04 & 15.48 & 17.28 & 23.33 & 21.14 & 21.69 \\
\hline 1985 & 15.34 & 16.69 & 19.18 & 18.96 & 16.65 & 18.41 & 24.06 & 22.16 & 22.76 \\
\hline 1986 & 15.01 & 16.25 & 18.56 & 18.31 & 16.13 & 17.71 & 22.78 & 20.95 & 21.37 \\
\hline 1987 & 13.70 & 14.79 & 16.84 & 16.51 & 14.38 & 15.70 & 20.14 & 18.29 & 18.41 \\
\hline
\end{tabular}

\begin{tabular}{|c|c|c|c|c|c|c|c|c|c|c|}
\hline TO THE & FROM & THE B & SINNII & $\mathrm{OF}$ & & & & & & \\
\hline END OF & 1978 & 1979 & 1980 & 1981 & 1982 & 1983 & 1984 & 1985 & 1986 & 1987 \\
\hline 1978 & 45.22 & & & & & & & & & \\
\hline 1979 & 49.13 & 53.15 & & & & & & & & \\
\hline 1980 & 53.32 & 57.54 & 62.06 & & & & & & & \\
\hline 1981 & 27.31 & 21.84 & 8.68 & -27.12 & & & & & & \\
\hline 1982 & 22.85 & 17.82 & 7.95 & -11.89 & 6.52 & & & & & \\
\hline 1983 & 24.57 & 20.81 & 13.85 & 1.21 & 19.27 & 33.55 & & & & \\
\hline 1984 & 19.09 & 15.22 & 8.85 & -1.46 & 8.96 & 10.20 & -9.07 & & & \\
\hline 1985 & 20.59 & 17.44 & 12.35 & 4.42 & 14.24 & 16.93 & 9.41 & 31.65 & & \\
\hline 1986 & 19.31 & 16.42 & 11.95 & 5.25 & 13.28 & 15.04 & 9.46 & 20.09 & 9.55 & \\
\hline 1987 & 16.32 & 13.49 & 9.32 & 3.34 & 9.53 & 10.14 & 4.96 & 10.11 & 0.69 & -7.45 \\
\hline
\end{tabular}


TABLE 5-31

LARGE CANADIAN EQUITIES (VALUE WEIGHTED): TOTAL RETURNS RATES OF RETURN FOR VARIOUS HOLDING PERIODS FROM 1950 TO 1987

\begin{tabular}{|c|c|c|c|c|c|c|c|c|c|}
\hline $\begin{array}{l}\text { TO THE } \\
\text { END OF }\end{array}$ & $\begin{array}{l}\text { FROM } \\
1950\end{array}$ & $\begin{array}{r}\text { HE BEC } \\
1951\end{array}$ & $\underset{1952}{\text { JNING OF }}$ & 1953 & 1954 & 1955 & 1956 & 1957 & 1958 \\
\hline 1950 & 30.41 & & & & & & & & \\
\hline 1951 & 27.71 & 25.07 & & & & & & & \\
\hline 1952 & 17.74 & 11.88 & 0.08 & & & & & & \\
\hline 1953 & 10.57 & 4.65 & -4.27 & -8.44 & & & & & \\
\hline 1954 & 16.62 & 13.41 & 9.77 & 14.96 & 44.34 & & & & \\
\hline 1955 & 17.79 & 15.41 & 13.12 & 17.83 & 33.67 & 23.79 & & & \\
\hline 1956 & 16.59 & 14.44 & 12.42 & 15.74 & 25.15 & 16.53 & 9.69 & & \\
\hline 1957 & 11.11 & 8.59 & 6.06 & 7.30 & 11.65 & 2.48 & -6.75 & -20.73 & \\
\hline 1958 & 13.11 & 11.11 & 9.25 & 10.86 & 15.18 & 8.86 & 4.30 & 1.70 & 30.48 \\
\hline 1959 & 12.04 & 10.17 & 8.44 & 9.68 & 13.04 & 7.64 & 3.95 & 2.10 & 15.87 \\
\hline 1960 & 11.06 & 9.29 & 7.67 & 8.65 & 11.34 & 6.63 & 3.49 & 2.00 & 10.94 \\
\hline 1961 & 12.79 & 11.31 & 10.02 & 11.18 & 13.92 & 10.13 & 8.00 & 7.67 & 16.23 \\
\hline 1962 & 11.06 & 9.58 & 8.28 & 9.13 & 11.28 & 7.72 & 5.60 & 4.94 & 10.99 \\
\hline 1963 & 11.28 & 9.93 & 8.76 & 9.58 & 11.57 & 8.42 & 6.64 & 6.21 & 11.52 \\
\hline 1964 & 12.10 & 10.90 & 9.87 & 10.73 & 12.66 & 9.91 & 8.46 & 8.31 & 13.25 \\
\hline 1965 & 11.62 & 10.47 & 9.50 & 10.26 & 11.98 & 9.42 & 8.08 & 7.90 & 12.14 \\
\hline 1966 & 10.54 & 9.40 & 8.43 & 9.05 & 10.53 & 8.10 & 6.77 & 6.48 & 10.03 \\
\hline 1967 & 11.01 & 9.96 & 9.08 & 9.70 & 11.13 & 8.92 & 7.76 & 7.59 & 10.92 \\
\hline 1968 & 11.48 & 10.52 & 9.72 & 10.35 & 11.73 & 9.70 & 8.69 & 8.61 & 11.76 \\
\hline 1969 & 10.83 & 9.89 & 9.10 & 9.66 & 10.90 & 8.97 & 7.98 & 7.85 & 10.65 \\
\hline 1970 & 10.20 & 9.28 & 8.50 & 8.99 & 10.11 & 8.27 & 7.30 & 7.14 & 9.65 \\
\hline 1971 & 10.22 & 9.34 & 8.61 & 9.08 & 10.15 & 8.41 & 7.51 & 7.37 & 9.72 \\
\hline 1972 & 10.97 & 10.16 & 9.50 & 9.99 & 11.06 & 9.46 & 8.67 & 8.60 & 10.91 \\
\hline 1973 & 10.32 & 9.52 & 8.86 & 9.30 & 10.27 & 8.72 & 7.94 & 7.84 & 9.93 \\
\hline 1974 & 8.53 & 7.70 & 7.00 & 7.33 & 8.14 & 6.59 & 5.76 & 5.54 & 7.33 \\
\hline 1975 & 8.98 & 8.20 & 7.54 & 7.88 & 8.69 & 7.23 & 6.46 & 6.30 & 8.04 \\
\hline 1976 & 9.07 & 8.32 & 7.70 & 8.03 & 8.81 & 7.42 & 6.70 & 6.55 & 8.22 \\
\hline 1977 & 9.26 & 8.55 & 7.96 & 8.29 & 9.05 & 7.72 & 7.05 & 6.92 & 8.53 \\
\hline 1978 & 9.89 & 9.22 & 8.67 & 9.02 & 9.78 & 8.54 & 7.92 & 7.84 & 9.43 \\
\hline 1979 & 11.07 & 10.46 & 9.97 & 10.35 & 11.15 & 9.99 & 9.45 & 9.44 & 11.06 \\
\hline 1980 & 11.54 & 10.96 & 10.50 & 10.90 & 11.69 & 10.59 & 10.09 & 10.11 & 11.69 \\
\hline 1981 & 10.81 & 10.23 & 9.76 & 10.11 & 10.84 & 9.76 & 9.26 & 9.24 & 10.71 \\
\hline 1982 & 10.59 & 10.02 & 9.57 & 9.90 & 10.59 & 9.54 & 9.05 & 9.02 & 10.42 \\
\hline 1983 & 11.28 & 10.75 & 10.33 & 10.67 & 11.37 & 10.38 & 9.93 & 9.94 & 11.33 \\
\hline 1984 & 10.91 & 10.38 & 9.97 & 10.29 & 10.95 & 9.98 & 9.54 & 9.53 & 10.85 \\
\hline 1985 & 11.28 & 10.77 & 10.38 & 10.71 & 11.36 & 10.44 & 10.02 & 10.03 & 11.32 \\
\hline 1986 & 11.31 & 10.82 & 10.44 & 10.76 & 11.40 & 10.50 & 10.10 & 10.11 & 11.37 \\
\hline 1987 & 11.07 & 10.59 & 10.22 & 10.52 & 11.13 & 10.26 & 9.86 & 9.86 & 11.07 \\
\hline
\end{tabular}




\section{TABLE 5-31 (Continued)}

\begin{tabular}{|c|c|c|c|c|c|c|c|c|c|c|}
\hline TO THE & FROM & THE B & GINNIN & OF & & & & & & \\
\hline END OF & 1959 & 1960 & 1961 & 1962 & 1963 & 1964 & 1965 & 1966 & 1967 & 1968 \\
\hline 1959 & 2.90 & & & & & & & & & \\
\hline 1960 & 2.30 & 1.70 & & & & & & & & \\
\hline 1961 & 11.84 & 16.60 & 33.68 & & & & & & & \\
\hline 1962 & 6.59 & 7.85 & 11.06 & -7.72 & & & & & & \\
\hline 1963 & 8.07 & 9.40 & 12.09 & 2.65 & 14.18 & & & & & \\
\hline 1964 & 10.61 & 12.22 & 15.01 & 9.39 & 19.10 & 24.22 & & & & \\
\hline 1965 & 9.74 & 10.93 & 12.87 & 8.19 & 14.09 & 14.04 & 4.69 & & & \\
\hline 1966 & 7.71 & 8.42 & 9.58 & 5.31 & 8.85 & 7.13 & -0.52 & -5.46 & & \\
\hline 1967 & 8.94 & 9.72 & 10.92 & 7.52 & 10.86 & 10.05 & 5.69 & 6.19 & 19.28 & \\
\hline 1968 & 10.04 & 10.87 & 12.07 & 9.28 & 12.41 & 12.05 & 9.20 & 10.75 & 19.87 & 20.46 \\
\hline 1969 & 9.01 & 9.64 & 10.56 & 7.96 & 10.41 & 9.80 & 7.12 & 7.74 & 12.53 & 9.31 \\
\hline 1970 & 8.07 & 8.55 & 9.26 & 6.84 & 8.82 & 8.07 & 5.59 & 5.77 & 8.78 & 5.49 \\
\hline 1971 & 8.27 & 8.73 & 9.39 & 7.22 & 9.02 & 8.40 & 6.31 & 6.58 & 9.16 & 6.77 \\
\hline 1972 & 9.63 & 10.16 & 10.90 & 9.03 & 10.86 & 10.50 & 8.90 & 9.51 & 12.23 & 10.87 \\
\hline 1973 & 8.68 & 9.11 & 9.70 & 7.91 & 9.45 & 8.99 & 7.42 & 7.77 & 9.80 & 8.30 \\
\hline 1974 & 6.03 & 6.25 & 6.58 & 4.74 & 5.85 & 5.12 & 3.38 & 3.24 & 4.38 & 2.41 \\
\hline 1975 & 6.85 & 7.10 & 7.47 & 5.81 & 6.93 & 6.35 & 4.85 & 4.87 & 6.09 & 4.54 \\
\hline 1976 & 7.11 & 7.36 & 7.72 & 6.18 & 7.25 & 6.74 & 5.40 & 5.46 & 6.62 & 5.30 \\
\hline 1977 & 7.49 & 7.75 & 8.11 & 6.69 & 7.73 & 7.28 & 6.08 & 6.19 & 7.32 & 6.19 \\
\hline 1978 & 8.47 & 8.77 & 9.18 & 7.89 & 8.95 & 8.61 & 7.57 & 7.79 & 8.98 & 8.09 \\
\hline 1979 & 10.21 & 10.59 & 11.08 & 9.94 & 11.08 & 10.88 & 10.05 & 10.44 & 11.77 & 11.17 \\
\hline 1980 & 10.91 & 11.30 & 11.81 & 10.76 & 11.89 & 11.76 & 11.02 & 11.45 & 12.77 & 12.29 \\
\hline 1981 & 9.92 & 10.25 & 10.68 & 9.64 & 10.64 & 10.44 & 9.68 & 10.00 & 11.12 & 10.56 \\
\hline 1982 & 9.66 & 9.96 & 10.35 & 9.35 & 10.28 & 10.08 & 9.34 & 9.62 & 10.64 & 10.09 \\
\hline 1983 & 10.63 & 10.96 & 11.38 & 10.46 & 11.42 & 11.28 & 10.64 & 10.98 & 12.03 & 11.59 \\
\hline 1984 & 10.16 & 10.46 & 10.84 & 9.94 & 10.82 & 10.66 & 10.02 & 10.31 & 11.26 & 10.81 \\
\hline 1985 & 10.67 & 10.98 & 11.37 & 10.53 & 11.40 & 11.27 & 10.69 & 11.00 & 11.94 & 11.55 \\
\hline 1986 & 10.74 & 11.04 & 11.42 & 10.61 & 11.45 & 11.33 & 10.77 & 11.07 & 11.97 & 11.60 \\
\hline 1987 & 10.45 & 10.73 & 11.08 & 10.29 & 11.08 & 10.95 & 10.41 & 10.68 & 11.51 & 11.14 \\
\hline
\end{tabular}




\section{TABLE 5-31 (Continued)}

\begin{tabular}{|c|c|c|c|c|c|c|c|c|c|}
\hline $\begin{array}{l}\text { TO THE } \\
\text { END OF }\end{array}$ & $\begin{array}{l}\text { FROM } \\
\mathbf{1 9 6 9}\end{array}$ & $\begin{array}{r}\text { HE BEC } \\
1970\end{array}$ & $\begin{array}{l}\text { JNING OF } \\
1971\end{array}$ & 1972 & 1973 & 1974 & 1975 & 1976 & 1977 \\
\hline 1969 & -0.82 & & & & & & & & \\
\hline 1970 & -1.28 & -1.74 & & & & & & & \\
\hline 1971 & 2.56 & 4.30 & 10.70 & & & & & & \\
\hline 1972 & 8.59 & 11.92 & 19.44 & 28.88 & & & & & \\
\hline 1973 & 6.01 & 7.79 & 11.17 & 11.41 & -3.69 & & & & \\
\hline 1974 & -0.33 & -0.23 & 0.15 & -3.14 & -16.03 & -26.78 & & & \\
\hline 1975 & 2.45 & 3.00 & 3.98 & 2.36 & -5.20 & -5.95 & 20.80 & & \\
\hline 1976 & 3.54 & 4.18 & 5.20 & 4.14 & -1.26 & -0.44 & 16.09 & 11.57 & \\
\hline 1977 & 4.72 & 5.43 & 6.49 & 5.81 & 1.72 & 3.11 & 15.58 & 13.06 & 14.57 \\
\hline 1978 & 6.92 & 7.82 & 9.08 & 8.85 & 5.83 & 7.84 & 18.80 & 18.14 & 21.58 \\
\hline 1979 & 10.36 & 11.54 & 13.12 & 13.43 & 11.38 & 14.11 & 24.70 & 25.70 & 30.80 \\
\hline 1980 & 11.63 & 12.84 & 14.41 & 14.83 & 13.18 & 15.82 & 25.03 & 25.89 & 29.75 \\
\hline 1981 & 9.83 & 10.77 & 11.98 & 12.11 & 10.38 & 12.28 & 19.35 & 19.11 & 20.69 \\
\hline 1982 & 9.38 & 10.21 & 11.27 & 11.32 & 9.70 & 11.30 & 17.28 & 16.79 & 17.69 \\
\hline 1983 & 11.02 & 11.92 & 13.05 & 13.24 & 11.92 & 13.61 & 19.30 & 19.11 & 20.23 \\
\hline 1984 & 10.23 & 11.01 & 11.98 & 12.08 & 10.78 & 12.20 & 17.10 & 16.69 & 17.35 \\
\hline 1985 & 11.04 & 11.83 & 12.80 & 12.95 & 11.81 & 13.21 & 17.78 & 17.49 & 18.16 \\
\hline 1986 & 11.13 & 11.87 & 12.78 & 12.92 & 11.86 & 13.16 & 17.34 & 17.03 & 17.59 \\
\hline 1987 & 10.67 & 11.34 & 12.16 & 12.25 & 11.23 & 12.38 & 16.14 & 15.76 & 16.15 \\
\hline
\end{tabular}

TO THE FROM THE BEGINNING OF

$\begin{array}{lcrrrrrrrrr}\text { END OF } & \mathbf{1 9 7 8} & \mathbf{1 9 7 9} & \mathbf{1 9 8 0} & \mathbf{1 9 8 1} & \mathbf{1 9 8 2} & \mathbf{1 9 8 3} & \mathbf{1 9 8 4} & \mathbf{1 9 8 5} & \mathbf{1 9 8 6} & \mathbf{1 9 8 7} \\ 1978 & 29.01 & & & & & & & & & \\ 1979 & 39.75 & 51.39 & & & & & & & & \\ 1980 & 35.24 & 38.47 & 26.65 & & & & & & & \\ 1981 & 22.26 & 20.09 & 6.96 & -9.66 & & & & & & \\ 1982 & 18.32 & 15.79 & 5.89 & -3.18 & 3.77 & & & & & \\ 1983 & 21.20 & 19.69 & 12.87 & 8.61 & 19.10 & 36.69 & & & & \\ 1984 & 17.75 & 15.97 & 9.95 & 6.13 & 11.99 & 16.34 & -0.97 & & & \\ 1985 & 18.62 & 17.21 & 12.31 & 9.65 & 15.09 & 19.12 & 11.21 & 24.89 & & \\ 1986 & 17.93 & 16.61 & 12.35 & 10.12 & 14.57 & 17.45 & 11.66 & 18.56 & 12.55 & \\ 1987 & 16.31 & 14.98 & 11.09 & 9.03 & 12.50 & 14.33 & 9.34 & 13.01 & 7.50 & 2.68\end{array}$


TABLE 5-32

SMALL CANADIAN EQUITIES (EQUAL WEIGHTED): TOTAL RETURNS RATES OF RETURN FOR VARIOUS HOLDING PERIODS FROM 1950 TO 1987

\begin{tabular}{|c|c|c|c|c|c|c|c|c|c|}
\hline $\begin{array}{l}\text { TO THE } \\
\text { END OF }\end{array}$ & $\begin{array}{l}\text { FROM } \\
1950\end{array}$ & $\underset{1951}{\text { HE BEG }}$ & $\begin{array}{l}\text { NNING OF } \\
1952\end{array}$ & 1953 & 1954 & 1955 & 1956 & 1957 & 1958 \\
\hline 1950 & 21.51 & & & & & & & & \\
\hline $\begin{array}{l}1951 \\
1952\end{array}$ & $\begin{array}{l}29.78 \\
23.36\end{array}$ & $\begin{array}{l}38.61 \\
24.29\end{array}$ & 11.45 & & & & & & \\
\hline 1953 & 16.31 & 14.63 & 4.25 & -2.49 & & & & & \\
\hline 1954 & 20.62 & 20.39 & 14.87 & 16.62 & 39.47 & & & & \\
\hline 1955 & 23.50 & 23.90 & 20.48 & 23.65 & 39.24 & 39.01 & & & \\
\hline 1956 & 19.87 & 19.60 & 16.13 & 17.32 & 24.79 & 18.04 & 0.23 & & \\
\hline 1957 & 13.92 & 12.88 & 9.08 & 8.61 & 11.58 & 3.58 & -10.59 & -20.24 & \\
\hline 1958 & 17.80 & 17.34 & 14.58 & 15.11 & 19.00 & 14.37 & 7.17 & 10.82 & 53.97 \\
\hline 1959 & 15.66 & 15.03 & 12.38 & 12.51 & 15.23 & 10.91 & 4.83 & 6.40 & 22.90 \\
\hline 1960 & 13.78 & 13.04 & 10.50 & 10.39 & 12.36 & 8.38 & 3.12 & 3.86 & 13.41 \\
\hline 1961 & 16.63 & 16.20 & 14.17 & 14.47 & 16.79 & 13.87 & 10.14 & 12.24 & 22.25 \\
\hline 1962 & 15.31 & 14.81 & 12.86 & 13.01 & 14.87 & 12.12 & 8.73 & 10.21 & 17.58 \\
\hline 1963 & 15.27 & 14.80 & 13.01 & 13.16 & 14.85 & 12.40 & 9.45 & 10.84 & 17.09 \\
\hline 1964 & 16.90 & 16.57 & 15.03 & 15.33 & 17.11 & 15.08 & 12.69 & 14.35 & 20.39 \\
\hline 1965 & 17.75 & 17.50 & 16.12 & 16.49 & 18.23 & 16.47 & 14.42 & 16.12 & 21.70 \\
\hline 1966 & 16.87 & 16.59 & 15.25 & 15.53 & 17.05 & 15.35 & 13.41 & 14.82 & 19.56 \\
\hline 1967 & 18.07 & 17.87 & 16.68 & 17.04 & 18.58 & 17.11 & 15.45 & 16.94 & 21.50 \\
\hline 1968 & 20.39 & 20.33 & 19.33 & 19.85 & 21.51 & 20.31 & 18.98 & 20.70 & 25.33 \\
\hline 1969 & 19.00 & 18.87 & 17.86 & 18.25 & 19.69 & 18.47 & 17.13 & 18.54 & 22.52 \\
\hline 1970 & 17.31 & 17.11 & 16.07 & 16.33 & 17.55 & 16.30 & 14.92 & 16.05 & 19.45 \\
\hline 1971 & 17.53 & 17.34 & 16.37 & 16.63 & 17.80 & 16.64 & 15.36 & 16.45 & 19.64 \\
\hline 1972 & 19.16 & 19.05 & 18.19 & 18.54 & 19.77 & 18.76 & 17.66 & 18.85 & 22.05 \\
\hline 1973 & 18.40 & 18.27 & 17.41 & 17.71 & 18.82 & 17.82 & 16.74 & 17.80 & 20.70 \\
\hline 1974 & 16.09 & 15.87 & 14.97 & 15.13 & 16.04 & 14.98 & 13.84 & 14.65 & 17.12 \\
\hline 1975 & 17.36 & 17.20 & 16.38 & 16.60 & 17.55 & 16.60 & 15.58 & 16.45 & 18.92 \\
\hline 1976 & 17.48 & 17.33 & 16.55 & 16.76 & 17.68 & 16.78 & 15.81 & 16.65 & 19.01 \\
\hline 1977 & 18.92 & 18.83 & 18.13 & 18.40 & 19.36 & 18.56 & 17.70 & 18.61 & 20.99 \\
\hline 1978 & 19.98 & 19.93 & 19.29 & 19.60 & 20.58 & 19.85 & 19.08 & 20.02 & 22.38 \\
\hline 1979 & 21.63 & 21.64 & 21.07 & 21.44 & 22.47 & 21.84 & 21.17 & 22.17 & 24.56 \\
\hline 1980 & 23.08 & 23.13 & 22.63 & 23.05 & 24.11 & 23.56 & 22.98 & 24.03 & 26.43 \\
\hline 1981 & 20.78 & 20.75 & 20.20 & 20.51 & 21.43 & 20.81 & 20.16 & 21.03 & 23.15 \\
\hline 1982 & 20.40 & 20.36 & 19.82 & 20.10 & 20.97 & 20.36 & 19.72 & 20.54 & 22.55 \\
\hline 1983 & 20.92 & 20.90 & 20.38 & 20.68 & 21.54 & 20.97 & 20.37 & 21.19 & 23.16 \\
\hline 1984 & 19.77 & 19.72 & 19.19 & 19.44 & 20.22 & 19.63 & 19.01 & 19.74 & 21.56 \\
\hline 1985 & 20.33 & 20.30 & 19.79 & 20.06 & 20.84 & 20.28 & 19.70 & 20.44 & 22.22 \\
\hline 1986 & 20.30 & 20.27 & 19.78 & 20.04 & 20.79 & 20.25 & 19.69 & 20.40 & 22.12 \\
\hline 1987 & 20.23 & 20.19 & 19.72 & 19.96 & 20.70 & 20.17 & 19.62 & 20.31 & 21.97 \\
\hline
\end{tabular}


TABLE 5-32 (Continued)

\begin{tabular}{|c|c|c|c|c|c|c|c|c|c|c|}
\hline TO THE & FROM & THE B & SINNII & 0 & & & & & & \\
\hline END OF & 1959 & 1960 & 1961 & 1962 & 1963 & 1964 & 1965 & 1966 & 1967 & 1968 \\
\hline 1959 & -1.91 & & & & & & & & & \\
\hline 1960 & -2.67 & -3.42 & & & & & & & & \\
\hline 1961 & 13.20 & 21.60 & 53.11 & & & & & & & \\
\hline 1962 & 9.91 & 14.16 & 24.12 & 0.61 & & & & & & \\
\hline 1963 & 10.85 & 14.29 & 20.89 & 7.41 & 14.67 & & & & & \\
\hline 1964 & 15.55 & 19.40 & 25.90 & 17.96 & 27.72 & 42.25 & & & & \\
\hline 1965 & 17.68 & 21.31 & 26.96 & 21.16 & 28.90 & 36.66 & 31.30 & & & \\
\hline 1966 & 15.84 & 18.63 & 22.76 & 17.46 & 22.09 & 24.67 & 16.72 & 3.76 & & \\
\hline 1967 & 18.34 & 21.15 & 25.14 & 21.00 & 25.55 & 28.43 & 24.13 & 20.70 & 40.40 & \\
\hline 1968 & 22.78 & 25.88 & 30.12 & 27.13 & 32.18 & 35.99 & 34.47 & 35.54 & 54.92 & 70.94 \\
\hline 1969 & 20.00 & 22.44 & 25.71 & 22.65 & 26.17 & 28.20 & 25.56 & 24.17 & 31.82 & 27.73 \\
\hline 1970 & 16.95 & 18.83 & 21.32 & 18.22 & 20.63 & 21.51 & 18.36 & 15.93 & 19.19 & 12.85 \\
\hline 1971 & 17.34 & 19.11 & 21.40 & 18.61 & 20.80 & 21.59 & 18.90 & 16.95 & 19.78 & 15.12 \\
\hline 1972 & 20.04 & 21.92 & 24.31 & 21.98 & 24.35 & 25.47 & 23.52 & 22.45 & 25.88 & 23.16 \\
\hline 1973 & 18.76 & 20.39 & 22.45 & 20.19 & 22.15 & 22.92 & 20.95 & 19.71 & 22.18 & 19.39 \\
\hline 1974 & 15.14 & 16.37 & 17.93 & 15.59 & 16.93 & 17.14 & 14.89 & 13.19 & 14.43 & 11.14 \\
\hline 1975 & 17.13 & 18.43 & 20.05 & 17.99 & 19.44 & 19.85 & 17.99 & 16.74 & 18.28 & 15.77 \\
\hline 1976 & 17.32 & 18.56 & 20.09 & 18.16 & 19.52 & 19.91 & 18.21 & 17.09 & 18.51 & 16.30 \\
\hline 1977 & 19.46 & 20.78 & 22.37 & 20.67 & 22.14 & 22.70 & 21.31 & 20.51 & 22.16 & 20.47 \\
\hline 1978 & 20.98 & 22.32 & 23.94 & 22.41 & 23.91 & 24.56 & 23.38 & 22.79 & 24.53 & 23.18 \\
\hline 1979 & 23.31 & 24.73 & 26.42 & 25.08 & 26.70 & 27.49 & 26.56 & 26.23 & 28.15 & 27.18 \\
\hline 1980 & 25.31 & 26.78 & 28.51 & 27.33 & 29.01 & 29.91 & 29.17 & 29.03 & 31.06 & 30.37 \\
\hline 1981 & 21.96 & 23.18 & 24.61 & 23.34 & 24.67 & 25.25 & 24.31 & 23.89 & 25.36 & 24.35 \\
\hline 1982 & 21.39 & 22.51 & 23.85 & 22.60 & 23.82 & 24.32 & 23.39 & 22.94 & 24.26 & 23.25 \\
\hline 1983 & 22.06 & 23.18 & 24.49 & 23.32 & 24.52 & 25.04 & 24.19 & 23.81 & 25.10 & 24.20 \\
\hline 1984 & 20.46 & 21.45 & 22.61 & 21.44 & 22.48 & 22.86 & 21.97 & 21.50 & 22.57 & 21.59 \\
\hline 1985 & 21.18 & 22.17 & 23.33 & 22.22 & 23.26 & 23.66 & 22.84 & 22.43 & 23.51 & 22.63 \\
\hline 1986 & 21.12 & 22.07 & 23.17 & 22.10 & 23.09 & 23.47 & 22.68 & 22.28 & 23.29 & 22.45 \\
\hline 1987 & 20.99 & 21.90 & 22.96 & 21.92 & 22.86 & 23.22 & 22.45 & 22.06 & 23.01 & 22.20 \\
\hline
\end{tabular}




\section{TABLE 5-32 (Continued)}

\begin{tabular}{|c|c|c|c|c|c|c|c|c|c|}
\hline $\begin{array}{l}\text { TO THE } \\
\text { END OF }\end{array}$ & $\begin{array}{l}\text { FROM } \\
1969\end{array}$ & $\underset{1970}{\text { HE BEG }}$ & $\begin{array}{l}\text { NNING OF } \\
1971\end{array}$ & 1972 & 1973 & 1974 & 1975 & 1976 & 1977 \\
\hline 1969 & -4.55 & & & & & & & & \\
\hline 1970 & -8.30 & -11.91 & & & & & & & \\
\hline 1971 & 0.90 & 3.75 & 22.18 & & & & & & \\
\hline 1972 & 13.46 & 20.19 & 40.40 & 61.33 & & & & & \\
\hline 1973 & 11.12 & 15.42 & 26.30 & 28.40 & 2.20 & & & & \\
\hline 1974 & 3.44 & 5.12 & 9.87 & 6.04 & -14.03 & -27.68 & & & \\
\hline 1975 & 9.50 & 12.04 & 17.56 & 16.43 & 4.43 & 5.57 & 54.10 & & \\
\hline 1976 & 10.83 & 13.23 & 18.06 & 17.26 & 8.27 & 10.37 & 36.34 & 20.63 & \\
\hline 1977 & 15.88 & 18.72 & 23.90 & 24.18 & 17.85 & 22.12 & 45.43 & 41.27 & 65.46 \\
\hline 1978 & 19.21 & 22.19 & 27.29 & 28.03 & 23.20 & 27.89 & 47.47 & 45.33 & 59.51 \\
\hline 1979 & 23.80 & 27.06 & 32.34 & 33.67 & 30.13 & 35.47 & 53.59 & 53.47 & 66.29 \\
\hline 1980 & 27.46 & 30.85 & 36.13 & 37.78 & 35.09 & 40.58 & 57.04 & 57.64 & 68.55 \\
\hline 1981 & 21.34 & 23.79 & 27.68 & 28.25 & 25.02 & 28.21 & 39.13 & 36.79 & 40.27 \\
\hline 1982 & 20.40 & 22.57 & 25.99 & 26.34 & 23.29 & 25.89 & 34.92 & 32.38 & 34.45 \\
\hline 1983 & 21.58 & 23.70 & 26.98 & 27.39 & 24.68 & 27.18 & 35.42 & 33.24 & 35.15 \\
\hline 1984 & 19.03 & 20.79 & 23.55 & 23.65 & 20.94 & 22.81 & 29.49 & 27.01 & 27.83 \\
\hline 1985 & 20.26 & 22.01 & 24.68 & 24.86 & 22.43 & 24.28 & 30.55 & 28.41 & 29.30 \\
\hline 1986 & 20.20 & 21.85 & 24.34 & 24.49 & 22.20 & 23.89 & 29.58 & 27.55 & 28.27 \\
\hline 1987 & 20.06 & 21.60 & 23.93 & 24.04 & 21.89 & 23.43 & 28.61 & 26.69 & 27.25 \\
\hline
\end{tabular}

\section{TO THE FROM THE BEGINNING OF}

\section{$\begin{array}{lllll}\text { END OF } & 1978 & 1979 & 1980 & 1981\end{array}$}

$\begin{array}{lrrrrr}1978 & 53.78 & & & & \\ 1979 & 66.71 & 80.72 & & & \\ 1980 & 69.59 & 78.09 & 75.50 & & \\ 1981 & 34.59 & 28.75 & 8.67 & -32.72 & \\ 1982 & 28.99 & 23.44 & 8.71 & -14.44 & 8.80 \\ 1983 & 30.67 & 26.48 & 15.69 & 0.68 & 23.16 \\ 1984 & 23.20 & 18.73 & 9.16 & -3.06 & 9.50 \\ 1985 & 25.38 & 21.77 & 14.02 & 4.60 & 16.79 \\ 1986 & 24.69 & 21.46 & 14.76 & 6.91 & 17.29 \\ 1987 & 23.95 & 21.02 & 15.10 & 8.37 & 17.33\end{array}$

1982

1983

1984

1985

1986

1987

39.43

$9.85-13.46$

$19.59 \quad 10.75$

$19.52 \quad 13.53$

$19.12 \quad 14.52$
41.73

$30.04 \quad 19.31$

$25.73 \quad 18.42$
17.54 
TABLE 5-33

LARGE CANADIAN EQUITIES (EQUAL WEIGHTED): TOTAL RETURNS RATES OF RETURN FOR VARIOUS HOLDING PERIODS FROM 1950 TO 1987

\begin{tabular}{|c|c|c|c|c|c|c|c|c|c|}
\hline $\begin{array}{l}\text { TO THE } \\
\text { END OF }\end{array}$ & $\begin{array}{l}\text { FROM } \\
1950\end{array}$ & $\begin{array}{l}\text { [E BEC } \\
1951\end{array}$ & $\begin{array}{l}\text { JNING OF } \\
1952\end{array}$ & 1953 & 1954 & 1955 & 1956 & 1957 & 1958 \\
\hline 1950 & 30.01 & & & & & & & & \\
\hline 1951 & 25.26 & 20.69 & & & & & & & \\
\hline 1952 & 18.36 & 12.94 & 5.69 & & & & & & \\
\hline 1953 & 12.73 & 7.50 & 1.45 & -2.61 & & & & & \\
\hline 1954 & 17.62 & 14.71 & 12.79 & 16.51 & 39.39 & & & & \\
\hline 1955 & 18.84 & 16.73 & 15.76 & 19.33 & 32.09 & 25.16 & & & \\
\hline 1956 & 16.38 & 14.25 & 13.00 & 14.91 & 21.42 & 13.33 & 2.61 & & \\
\hline 1957 & 11.60 & 9.20 & 7.39 & 7.73 & 10.49 & 2.25 & -7.58 & -16.76 & \\
\hline 1958 & 14.41 & 12.59 & 11.48 & 12.48 & 15.77 & 10.52 & 6.02 & 7.78 & 39.54 \\
\hline 1959 & 12.97 & 11.22 & 10.09 & 10.74 & 13.13 & 8.51 & 4.70 & 5.41 & 18.62 \\
\hline 1960 & 11.55 & 9.86 & 8.72 & 9.10 & 10.89 & 6.74 & 3.39 & 3.59 & 11.42 \\
\hline 1961 & 13.61 & 12.22 & 11.41 & 12.07 & 14.05 & 10.83 & 8.60 & 9.84 & 17.73 \\
\hline 1962 & 12.22 & 10.85 & 10.00 & 10.44 & 12.00 & 8.97 & 6.84 & 7.56 & 13.22 \\
\hline 1963 & 12.52 & 11.28 & 10.53 & 10.98 & 12.44 & 9.79 & 8.01 & 8.80 & 13.77 \\
\hline 1964 & 13.28 & 12.17 & 11.54 & 12.04 & 13.48 & 11.17 & 9.71 & 10.64 & 15.23 \\
\hline 1965 & 12.92 & 11.87 & 11.26 & 11.70 & 12.99 & 10.85 & 9.51 & 10.31 & 14.26 \\
\hline 1966 & 11.78 & 10.73 & 10.09 & 10.42 & 11.49 & 9.43 & 8.10 & 8.67 & 11.94 \\
\hline 1967 & 12.09 & 11.12 & 10.54 & 10.87 & 11.91 & 10.03 & 8.86 & 9.44 & 12.48 \\
\hline 1968 & 13.02 & 12.15 & 11.66 & 12.05 & 13.10 & 11.42 & 10.43 & 11.11 & 14.07 \\
\hline 1969 & 12.11 & 11.24 & 10.73 & 11.04 & 11.95 & 10.33 & 9.34 & 9.88 & 12.45 \\
\hline 1970 & 11.16 & 10.29 & 9.77 & 10.00 & 10.79 & 9.21 & 8.23 & 8.64 & 10.89 \\
\hline 1971 & 11.19 & 10.36 & 9.87 & 10.09 & 10.85 & 9.36 & 8.44 & 8.84 & 10.95 \\
\hline 1972 & 11.92 & 11.16 & 10.73 & 10.98 & 11.75 & 10.39 & 9.57 & 10.02 & 12.09 \\
\hline 1973 & 11.12 & 10.36 & 9.92 & 10.12 & 10.80 & 9.47 & 8.66 & 9.02 & 10.88 \\
\hline 1974 & 9.22 & 8.43 & 7.92 & 8.02 & 8.56 & 7.21 & 6.34 & 6.55 & 8.11 \\
\hline 1975 & 9.83 & 9.09 & 8.63 & 8.76 & 9.31 & 8.05 & 7.26 & 7.51 & 9.04 \\
\hline 1976 & 10.16 & 9.46 & 9.03 & 9.18 & 9.72 & 8.53 & 7.80 & 8.06 & 9.56 \\
\hline 1977 & 10.80 & 10.15 & 9.76 & 9.93 & 10.48 & 9.37 & 8.71 & 9.00 & 10.48 \\
\hline 1978 & 11.62 & 11.01 & 10.67 & 10.87 & 11.44 & 10.41 & 9.81 & 10.15 & 11.63 \\
\hline 1979 & 12.63 & 12.08 & 11.78 & 12.01 & 12.62 & 11.66 & 11.13 & 11.52 & 13.01 \\
\hline 1980 & 13.52 & 13.00 & 12.75 & 13.01 & 13.63 & 12.74 & 12.27 & 12.69 & 14.19 \\
\hline 1981 & 12.39 & 11.86 & 11.58 & 11.78 & 12.34 & 11.44 & 10.95 & 11.29 & 12.65 \\
\hline 1982 & 12.00 & 11.47 & 11.19 & 11.38 & 11.89 & 11.02 & 10.53 & 10.84 & 12.12 \\
\hline 1983 & 12.71 & 12.23 & 11.97 & 12.18 & 12.71 & 11.89 & 11.44 & 11.78 & 13.06 \\
\hline 1984 & 12.10 & 11.61 & 11.35 & 11.53 & 12.02 & 11.20 & 10.75 & 11.05 & 12.25 \\
\hline 1985 & 12.62 & 12.15 & 11.91 & 12.11 & 12.60 & 11.83 & 11.41 & 11.73 & 12.91 \\
\hline 1986 & 12.71 & 12.26 & 12.03 & 12.22 & 12.71 & 11.96 & 11.56 & 11.87 & 13.02 \\
\hline 1987 & 12.22 & 11.78 & 11.54 & 11.71 & 12.17 & 11.43 & 11.03 & 11.31 & 12.39 \\
\hline
\end{tabular}




\section{TABLE 5-33 (Continued)}

\begin{tabular}{|c|c|c|c|c|c|c|c|c|c|c|}
\hline TO THE & FROM & THE B & IINNIN & OF & & & & & & \\
\hline END OF & 1959 & 1960 & 1961 & 1962 & 1963 & 1964 & 1965 & 1966 & 1967 & 1968 \\
\hline 1959 & 0.84 & & & & & & & & & \\
\hline 1960 & -0.44 & -1.69 & & & & & & & & \\
\hline 1961 & 11.24 & 16.84 & 38.86 & & & & & & & \\
\hline 1962 & 7.46 & 9.76 & 15.97 & -3.15 & & & & & & \\
\hline 1963 & 9.21 & 11.41 & 16.16 & 6.24 & 16.53 & & & & & \\
\hline 1964 & 11.61 & 13.89 & 18.16 & 11.97 & 20.40 & 24.39 & & & & \\
\hline 1965 & 11.04 & 12.84 & 16.00 & 10.89 & 16.01 & 15.75 & 7.72 & & & \\
\hline 1966 & 8.89 & 10.10 & 12.19 & 7.51 & 10.35 & 8.36 & 1.14 & -5.03 & & \\
\hline 1967 & 9.82 & 10.99 & 12.94 & 9.11 & 11.74 & 10.58 & 6.32 & 5.63 & 17.50 & \\
\hline 1968 & 11.79 & 13.08 & 15.07 & 12.02 & 14.77 & 14.43 & 12.06 & 13.55 & 24.16 & 31.21 \\
\hline 1969 & 10.26 & 11.25 & 12.79 & 9.90 & 11.90 & 11.14 & 8.67 & 8.91 & 14.00 & 12.28 \\
\hline 1970 & 8.78 & 9.54 & 10.73 & 7.98 & 9.45 & 8.48 & 6.03 & 5.70 & 8.56 & 5.74 \\
\hline 1971 & 9.01 & 9.72 & 10.82 & 8.35 & 9.71 & 8.88 & 6.83 & 6.69 & 9.20 & 7.22 \\
\hline 1972 & 10.35 & 11.12 & 12.26 & 10.11 & 11.53 & 10.99 & 9.42 & 9.66 & 12.32 & 11.32 \\
\hline 1973 & 9.19 & 9.81 & 10.75 & 8.68 & 9.83 & 9.18 & 7.61 & 7.60 & 9.53 & 8.26 \\
\hline 1974 & 6.40 & 6.78 & 7.41 & 5.31 & 6.05 & 5.14 & 3.39 & 2.92 & 3.96 & 2.16 \\
\hline 1975 & 7.47 & 7.90 & 8.57 & 6.68 & 7.48 & 6.76 & 5.28 & 5.04 & 6.23 & 4.90 \\
\hline 1976 & 8.10 & 8.54 & 9.21 & 7.48 & 8.28 & 7.67 & 6.38 & 6.26 & 7.46 & 6.40 \\
\hline 1977 & 9.13 & 9.62 & 10.32 & 8.74 & 9.59 & 9.11 & 8.01 & 8.04 & 9.31 & 8.52 \\
\hline 1978 & 10.39 & 10.92 & 11.66 & 10.24 & 11.13 & 10.78 & 9.87 & 10.04 & 11.40 & 10.86 \\
\hline 1979 & 11.88 & 12.47 & 13.26 & 11.99 & 12.95 & 12.73 & 11.99 & 12.30 & 13.76 & 13.46 \\
\hline 1980 & 13.15 & 13.78 & 14.61 & 13.46 & 14.46 & 14.34 & 13.74 & 14.15 & 15.66 & 15.52 \\
\hline 1981 & 11.60 & 12.12 & 12.82 & 11.66 & 12.50 & 12.28 & 11.60 & 11.85 & 13.08 & 12.77 \\
\hline 1982 & 11.10 & 11.57 & 12.22 & 11.08 & 11.85 & 11.61 & 10.94 & 11.13 & 12.23 & 11.88 \\
\hline 1983 & 12.11 & 12.61 & 13.27 & 12.23 & 13.02 & 12.85 & 12.27 & 12.53 & 13.66 & 13.42 \\
\hline 1984 & 11.31 & 11.75 & 12.35 & 11.32 & 12.03 & 11.82 & 11.22 & 11.41 & 12.40 & 12.11 \\
\hline 1985 & 12.02 & 12.48 & 13.09 & 12.12 & 12.84 & 12.67 & 12.14 & 12.37 & 13.37 & 13.14 \\
\hline 1986 & 12.17 & 12.61 & 13.20 & 12.28 & 12.97 & 12.82 & 12.32 & 12.55 & 13.50 & 13.30 \\
\hline 1987 & 11.56 & 11.96 & 12.50 & 11.59 & 12.23 & 12.05 & 11.54 & 11.72 & 12.59 & 12.35 \\
\hline
\end{tabular}




\section{TABLE 5-33 (Continued)}

\begin{tabular}{|c|c|c|c|c|c|c|c|c|c|}
\hline $\begin{array}{l}\text { TO THE } \\
\text { END OF }\end{array}$ & $\begin{array}{l}\text { FROM } \\
1969\end{array}$ & $\begin{array}{c}\text { HE BEG } \\
1970\end{array}$ & $\begin{array}{l}\text { INING OF } \\
1971\end{array}$ & 1972 & 1973 & 1974 & 1975 & 1976 & 1977 \\
\hline 1969 & -3.91 & & & & & & & & \\
\hline 1970 & -5.08 & -6.23 & & & & & & & \\
\hline 1971 & 0.24 & 2.38 & 11.77 & & & & & & \\
\hline 1972 & 6.83 & 10.68 & 20.24 & 29.34 & & & & & \\
\hline 1973 & 4.18 & 6.30 & 10.84 & 10.37 & -5.81 & & & & \\
\hline 1974 & -2.01 & -1.63 & -0.44 & -4.21 & -17.57 & -27.85 & & & \\
\hline 1975 & 1.60 & 2.55 & 4.40 & 2.63 & -4.99 & -4.57 & 26.22 & & \\
\hline 1976 & 3.65 & 4.78 & 6.73 & 5.75 & 0.56 & 2.78 & 22.68 & 19.24 & \\
\hline 1977 & 6.26 & 7.60 & 9.74 & 9.40 & 5.80 & 8.92 & 24.96 & 24.33 & 29.63 \\
\hline 1978 & 9.00 & 10.54 & 12.84 & 12.99 & 10.48 & 14.06 & 27.90 & 28.46 & 33.33 \\
\hline 1979 & 11.97 & 13.69 & 16.15 & 16.71 & 15.01 & 18.91 & 31.40 & 32.73 & 37.56 \\
\hline 1980 & 14.30 & 16.12 & 18.63 & 19.42 & 18.23 & 22.13 & 33.33 & 34.80 & 39.00 \\
\hline 1981 & 11.46 & 12.85 & 14.76 & 15.07 & 13.58 & 16.27 & 24.48 & 24.19 & 25.20 \\
\hline 1982 & 10.62 & 11.82 & 13.47 & 13.63 & 12.17 & 14.37 & 21.15 & 20.44 & 20.64 \\
\hline 1983 & 12.32 & 13.58 & 15.27 & 15.57 & 14.39 & 16.63 & 23.03 & 22.64 & 23.13 \\
\hline 1984 & 11.01 & 12.09 & 13.52 & 13.66 & 12.44 & 14.27 & 19.65 & 18.94 & 18.90 \\
\hline 1985 & 12.16 & 13.25 & 14.69 & 14.90 & 13.85 & 15.67 & 20.74 & 20.21 & 20.31 \\
\hline 1986 & 12.38 & 13.42 & 14.77 & 14.98 & 14.01 & 15.70 & 20.35 & 19.83 & 19.89 \\
\hline 1987 & 11.43 & 12.35 & 13.56 & 13.67 & 12.69 & 14.15 & 18.25 & 17.61 & 17.46 \\
\hline
\end{tabular}

\begin{tabular}{lllrrrrrrrr} 
TO THE & \multicolumn{2}{c}{ FROM THE BEGINNING OF } & & & & & \\
END OF & $\mathbf{1 9 7 8}$ & $\mathbf{1 9 7 9}$ & $\mathbf{1 9 8 0}$ & $\mathbf{1 9 8 1}$ & $\mathbf{1 9 8 2}$ & $\mathbf{1 9 8 3}$ & $\mathbf{1 9 8 4}$ & $\mathbf{1 9 8 5}$ & $\mathbf{1 9 8 6}$ & $\mathbf{1 9 8 7}$ \\
1978 & 37.14 & & & & & & & & & \\
1979 & 41.70 & 46.41 & & & & & & & & \\
1980 & 42.27 & 44.91 & 43.42 & & & & & & & \\
1981 & 24.12 & 20.06 & 8.72 & -17.59 & & & & & \\
1982 & 18.92 & 14.75 & 5.80 & -9.13 & 0.20 & & & & & \\
1983 & 22.08 & 19.27 & 13.31 & 4.75 & 18.10 & 39.19 & & & & \\
1984 & 17.44 & 14.44 & 8.94 & 1.70 & 9.09 & 13.83 & -6.91 & & & \\
1985 & 19.20 & 16.83 & 12.52 & 7.19 & 14.47 & 19.66 & 10.95 & 32.25 & & \\
1986 & 18.85 & 16.74 & 13.03 & 8.63 & 14.80 & 18.77 & 12.65 & 23.92 & 16.12 & \\
1987 & 16.30 & 14.20 & 10.70 & 6.68 & 11.37 & 13.75 & 8.15 & 13.70 & 5.43 & -4.28
\end{tabular}




\section{TABLE 5-34}

\section{MARKET SENSITIVITIES REGRESSION OUTPUT BASED ON LOG OF MONTHLY EXCESS RETURNS 1982 TO 1987}

\begin{tabular}{|c|c|c|c|c|c|c|}
\hline TICKER & NAME & $\begin{array}{l}\text { AVEKAGE } \\
\text { TOTAL } \\
\text { RETURN } \\
\end{array}$ & BETA & $\begin{array}{l}\text { SE } \\
\text { BETA }\end{array}$ & $\begin{array}{c}\text { R- } \\
\text { SQUARED }\end{array}$ & $\begin{array}{c}\text { TOTAL } \\
\text { VARIANCE } \\
\text { (ER) } \\
\end{array}$ \\
\hline A & ABITIBI-PRICE INC. & 0.039 & 0.698 & 0.329 & 0.073 & 0.00903 \\
\hline $\mathrm{ACK}$ & ACKLANDS LTD. & 0.009 & 0.280 & 0.119 & 0.086 & 0.00218 \\
\hline ACM.B & ASTRAL BELLEVUE PATHE IN & 0.016 & 0.937 & 0.324 & 0.126 & 0.01683 \\
\hline ACO.X & ATCO LTD. CL 'I' NV & 0.006 & 1.166 & 0.220 & 0.323 & 0.01012 \\
\hline ADW.A & ANDRES WINES LTD. CL 'A' & 0.008 & 0.884 & 0.207 & 0.237 & 0.00792 \\
\hline ADW.B & ANDRES WINES LTD. CL 'B' & 0.009 & 0.850 & 0.234 & 0.182 & 0.00950 \\
\hline AEC & ALBERTA ENERGY COMPANY L & 0.007 & 1.297 & 0.198 & 0.422 & 0.00956 \\
\hline AEO & AMERICAN EAGLE PETROLEUM & -0.003 & 1.485 & 0.222 & 0.430 & 0.01230 \\
\hline AGE & AGNICO-EAGLE MINES LTD. & 0.014 & 1.497 & 0.275 & 0.334 & 0.01608 \\
\hline AGR.A & AGRA INDUSTRIES LTD. CL & 0.022 & 1.009 & 0.254 & 0.214 & 0.01163 \\
\hline AGZ & AGASSIZ RESOURCES LTD. & 0.015 & 0.620 & 0.241 & 0.101 & 0.00913 \\
\hline AIL & AMCA INTERNATIONAL LTD. & -0.005 & 1.132 & 0.214 & 0.323 & 0.00953 \\
\hline AIN & ATLANTIS INTERNATIONAL L & 0.040 & 0.736 & 0.562 & 0.028 & 0.04596 \\
\hline $\mathrm{AL}$ & ALCAN ALUMINIUM LTD. & 0.020 & 0.924 & 0.246 & 0.204 & 0.00581 \\
\hline ALG & ALGOMA STEEL CORP. LTD. & -0.002 & 1.106 & 0.238 & 0.268 & 0.01095 \\
\hline AM & ALGONQUIN MERCANTILE COR & 0.034 & 0.508 & 0.284 & 0.080 & 0.01044 \\
\hline ANG & ALBERTA NATURAL GAS CO. & 0.015 & 0.695 & 0.158 & 0.246 & 0.00471 \\
\hline ARL & AMERICAN LEDUC PETROLEUM & 0.003 & 0.814 & 0.267 & 0.136 & 0.01170 \\
\hline ASM & ASAMERA INC. & 0.016 & 1.743 & 0.274 & 0.407 & 0.01789 \\
\hline $\mathrm{AU}$ & AUGMITTO EXPLORATIONS LT & 0.022 & 2.113 & 0.510 & 0.225 & 0.04753 \\
\hline AY & ATLAS YELLOWKNIFE RESOUR & -0.002 & 1.469 & 0.365 & 0.215 & 0.02406 \\
\hline AYE.A & ARGYLL ENERGY CORPORATIO & -0.013 & 1.936 & 0.325 & 0.379 & 0.02412 \\
\hline AYO & ALBANY OIL \& GAS LTD. J & 0.033 & 1.210 & 0.732 & 0.044 & 0.07942 \\
\hline B & BELL CANADA ENTERPRISES & 0.013 & 0.318 & 0.113 & 0.118 & 0.00205 \\
\hline $\mathrm{BBC}$ & BANK OF BRITISH COLUMBIA & -0.033 & 0.868 & 0.624 & 0.032 & 0.05694 \\
\hline BBD.A & BOMBARDIER INC. CL 'A' & 0.029 & 0.902 & 0.248 & 0.183 & 0.01067 \\
\hline BBD.B & BOMBARDIER INC. CL 'B' S & 0.032 & 0.994 & 0.251 & 0.209 & 0.01131 \\
\hline $\mathrm{BCF}$ & BRITISH COLUMBIA FOREST & 0.019 & 1.172 & 0.197 & 0.375 & 0.00879 \\
\hline $\mathrm{BCI}$ & BRITISH COLUMBIA RESOURC & -0.017 & 0.782 & 0.173 & 0.257 & 0.00570 \\
\hline BCS.A & B.C. SUGAR REFINERY LTD. & 0.015 & 0.707 & 0.157 & 0.256 & 0.00468 \\
\hline $\mathrm{BD}$ & BCE DEVELOPMENT CORP. & 0.014 & 1.020 & 0.366 & 0.116 & 0.02150 \\
\hline BL.A & BRASCAN LTD. CL'A' & 0.025 & 1.508 & 0.142 & 0.661 & 0.00820 \\
\hline BLG & BACHELOR LAKE GOLD MINES & -0.007 & 1.389 & 0.395 & 0.173 & 0.02670 \\
\hline $\mathrm{BMO}$ & BANK OF MONTREAL & 0.008 & 0.697 & 0.139 & 0.298 & 0.00391 \\
\hline
\end{tabular}




\section{TABLE 5-34 (Continued)}

\begin{tabular}{|c|c|c|c|c|c|c|}
\hline TICKER & $\underline{\text { NAME }}$ & $\begin{array}{c}\text { AVEKAGE } \\
\text { TOTAL } \\
\text { RETURN }\end{array}$ & $\underline{\text { BETA }}$ & $\begin{array}{l}\text { SE } \\
\text { BETA }\end{array}$ & $\begin{array}{c}\text { R- } \\
\text { SQUARED }\end{array}$ & $\begin{array}{c}\text { TUTAL } \\
\text { VARIANCE } \\
\text { (ER) }\end{array}$ \\
\hline BMS & BRUNSWICK MINING \& SMELT & 0.005 & 1.239 & 0.216 & 0.358 & 0.01028 \\
\hline BND & BRENDA MINES LTD. & 0.012 & 0.905 & 0.304 & 0.130 & 0.01509 \\
\hline BNR & BROULAN RESOURCES INC. & 0.011 & 1.525 & 0.324 & 0.277 & 0.01959 \\
\hline BNS & BANK OF NOVA SCOTIA (THE) & 0.008 & 0.784 & 0.142 & 0.341 & 0.00431 \\
\hline BOW & BOW VALLEY RESOURCE SERV & -0.017 & 1.631 & 0.400 & 0.220 & 0.02901 \\
\hline $\mathrm{BPC}$ & BP CANADA INC. & 0.014 & 0.939 & 0.221 & 0.237 & 0.00902 \\
\hline $\mathrm{BRR}$ & BRUNCOR INC. & 0.010 & 0.268 & 0.100 & 0.110 & 0.00159 \\
\hline BRT.A & BRIGHT T.G. \& CO. LTD. C & 0.007 & 0.594 & 0.202 & 0.128 & 0.00661 \\
\hline BUD & BUDD CANADA INC. & 0.030 & 0.733 & 0.249 & 0.128 & 0.01005 \\
\hline $\mathrm{C}$ & CHRYSLER CORP. & 0.030 & 0.939 & 0.389 & 0.093 & 0.01292 \\
\hline $\mathrm{CAH}$ & CANARCHON HOLDINGS LTD. & 0.016 & 1.365 & 0.459 & 0.132 & 0.03440 \\
\hline CAO.A & CARA OPERATIONS LTD. CL & 0.028 & 0.879 & 0.232 & 0.195 & 0.00951 \\
\hline CB.A & CONSOLIDATED-BATHURST IN & 0.032 & 0.962 & 0.184 & 0.316 & 0.00702 \\
\hline $\mathrm{CCH}$ & CAMPBELL RESOURCES INC. & -0.022 & 1.720 & 0.344 & 0.305 & 0.02406 \\
\hline CCL & CELANESE CANADA INC. & 0.028 & 1.300 & 0.234 & 0.343 & 0.01181 \\
\hline CCQ.A & CCL INDUSTRIES INC. CL' & 0.019 & 0.794 & 0.251 & 0.147 & 0.01045 \\
\hline $\mathrm{CDC}$ & CANADA DEVELOPMENT CORP. & 0.019 & 1.541 & 0.360 & 0.237 & 0.02404 \\
\hline CDL.B & CORBY DISTILLERIES LTD. & 0.012 & 0.108 & 0.180 & 0.006 & 0.00461 \\
\hline CEF.A & CENTRAL FUND OF CANADA L & 0.001 & 0.871 & 0.233 & 0.194 & 0.00947 \\
\hline CEX.A & CONWEST EXPLORATION CO. & 0.019 & 1.576 & 0.230 & 0.443 & 0.01344 \\
\hline CEX.B & CONWEST EXPLORATION CO. & 0.017 & 1.263 & 0.243 & 0.314 & 0.01218 \\
\hline CFI & CRESTBROOK FOREST INDUST & 0.010 & 1.403 & 0.290 & 0.284 & 0.01662 \\
\hline $\mathrm{CFJ}$ & COBI FOODS INC. & 0.012 & 0.862 & 0.341 & 0.098 & 0.01825 \\
\hline $\mathrm{CFL}$ & CORPORATE FOODS LTD. & 0.022 & 0.490 & 0.696 & 0.009 & 0.04292 \\
\hline CGC & CONSUMERS PACKAGING INC. & 0.023 & 1.056 & 0.150 & 0.455 & 0.00587 \\
\hline GEZ & CANADIAN GENERAL ELECTRI & 0.020 & 0.691 & 0.213 & 0.151 & 0.00759 \\
\hline $\mathrm{CGH}$ & COMPUTALOG GEARHART LTD. & 0.016 & 1.683 & 0.331 & 0.305 & 0.02231 \\
\hline CGI & CANADIAN GENERAL INVESTM & 0.014 & 0.363 & 0.143 & 0.099 & 0.00319 \\
\hline CGR & CANADIAN ARROW MINES LTD & 0.015 & 1.262 & 0.526 & 0.101 & 0.03873 \\
\hline $\mathrm{CHC}$ & CHANCELLOR ENERGY RESOUR & -0.015 & 0.748 & 0.391 & 0.059 & 0.02295 \\
\hline $\mathrm{CHM}$ & CHUM LTD. & 0.020 & 0.189 & 0.243 & 0.010 & 0.00840 \\
\hline CHM.B & CHUM LTD. CL 'B' NV & 0.021 & 0.315 & 0.176 & 0.052 & 0.00461 \\
\hline CID & CHIEFTAIN DEVELOPMENT CO & -0.002 & 1.526 & 0.274 & 0.345 & 0.01618 \\
\hline CIL & C-I-L INC. & 0.007 & 0.858 & 0.138 & 0.395 & 0.00448 \\
\hline
\end{tabular}




\section{TABLE 5-34 (Continued)}

\begin{tabular}{|c|c|c|c|c|c|c|}
\hline TICKER & $\underline{\text { NAME }}$ & $\begin{array}{l}\text { TOTAL } \\
\text { RETURN } \\
\end{array}$ & BETA & $\begin{array}{l}\text { SE } \\
\text { BETA }\end{array}$ & $\begin{array}{c}\text { R- } \\
\text { SQUARED }\end{array}$ & $\begin{array}{c}\text { TUTAL } \\
\text { VARIANCE } \\
\text { (ER) }\end{array}$ \\
\hline $\mathrm{CJC}$ & CANCAPITAL CORP. & 0.001 & 0.959 & 0.360 & 0.111 & 0.01957 \\
\hline CJX & CANADIAN JOREX LTD. & 0.002 & 1.014 & 0.360 & 0.120 & 0.01926 \\
\hline $\mathrm{CK}$ & CANADA PACKERS INC. & 0.020 & 0.430 & 0.141 & 0.136 & 0.00326 \\
\hline CKS & COSEKA RESOURCES LTD. & -0.023 & 1.539 & 0.329 & 0.271 & 0.02098 \\
\hline CLA & CROWN LIFE INSURANCE CO. & 0.024 & 0.370 & 0.230 & 0.047 & 0.00747 \\
\hline CME.A & CME CAPITAL INC. CL 'A' & 0.029 & 0.778 & 0.651 & 0.024 & 0.06143 \\
\hline CMP & CAMPEAU CORP. SV & 0.029 & 1.775 & 0.211 & 0.544 & 0.01389 \\
\hline $\mathrm{MQ}$ & CANADIAN MANOIR INDUSTRI & 0.018 & 0.510 & 0.299 & 0.047 & 0.01326 \\
\hline CMR & CAMRECO INC. J & -0.006 & 0.301 & 0.517 & 0.006 & 0.03803 \\
\hline CMW & CANADIAN MARCONI CO. & 0.010 & 1.206 & 0.198 & 0.391 & 0.00908 \\
\hline $\mathrm{CNC}$ & CANUC RESOURCES INC. J & 0.009 & 0.597 & 0.523 & 0.022 & 0.03960 \\
\hline CNQ & CANADIAN NATURAL RESOURC & -0.047 & 1.441 & 0.524 & 0.127 & 0.04108 \\
\hline CNR & CANADIAN ROXY PETROLEUM & 0.005 & 0.795 & 0.264 & 0.137 & 0.01137 \\
\hline CNW & CANADA NORTHWEST ENERGY & 0.004 & 1.094 & 0.264 & 0.225 & 0.01276 \\
\hline $\mathrm{CO}$ & CONIAGAS MINES LTD. (THE) & 0.008 & 1.290 & 0.446 & 0.124 & 0.03215 \\
\hline COI & COIN LAKE GOLD MINES LTD & 0.058 & 0.944 & 0.605 & 0.040 & 0.05392 \\
\hline $\mathrm{COO}$ & COLONIAL OIL \& GAS LTD. & -0.004 & 0.312 & 0.494 & 0.007 & 0.03480 \\
\hline COT & COSCAN DEVELOPMENT CORP. & 0.009 & 1.013 & 0.182 & 0.344 & 0.00716 \\
\hline $\mathrm{CP}$ & CANADIAN PACIFIC LTD. & 0.021 & 1.376 & 0.197 & 0.462 & 0.00556 \\
\hline $\mathrm{CPF}$ & CONSOLIDATED PROFESSOR M & 0.008 & 1.835 & 0.395 & 0.268 & 0.03018 \\
\hline CPX & CINEPLEX ODEON CORP. & 0.025 & 0.803 & 0.325 & 0.094 & 0.01653 \\
\hline CRL & CRAIN INC. R.L. SV & 0.017 & 0.671 & 0.188 & 0.177 & 0.00609 \\
\hline CRX & CROWNX INC. & 0.004 & 1.484 & 0.209 & 0.462 & 0.01144 \\
\hline CRX.A & CROWNX INC. CL 'A' NV & 0.002 & 1.203 & 0.203 & 0.373 & 0.00931 \\
\hline CSF & CANADIAN SPOONER RESOURC & -0.006 & 0.861 & 0.386 & 0.079 & 0.02275 \\
\hline CSH.A & CABLESHARE INC. CL'A' S & 0.054 & 2.133 & 0.735 & 0.127 & 0.08540 \\
\hline CSW & CANADA SOUTHERN PETROLEU & -0.001 & 1.498 & 0.340 & 0.251 & 0.02174 \\
\hline CFS & CANADA TRUSTCO MORTGAGE & 0.042 & -1.038 & 0.522 & 0.063 & 0.04113 \\
\hline CTL & CONTINENTAL BANK OF CANA & 0.002 & 0.613 & 0.598 & 0.017 & 0.05154 \\
\hline CTM & CANADA TUNGSTEN MINING C & -0.010 & 0.725 & 0.297 & 0.092 & 0.01375 \\
\hline CTR.A & CANADIAN TIRE CORP. LTD. & 0.009 & 0.823 & 0.192 & 0.237 & 0.00685 \\
\hline CTT.A & CHALLENGER INTERNATIONAL & 0.004 & 0.864 & 0.523 & 0.044 & 0.04056 \\
\hline $\mathrm{CU}$ & CANADIAN UTILITIES LTD. & 0.009 & 0.197 & 0.134 & 0.035 & 0.00262 \\
\hline CU.X & CANADIAN UTILITIES LTD. & 0.011 & 0.206 & 0.129 & 0.041 & 0.00246 \\
\hline
\end{tabular}




\section{TABLE 5-34 (Continued)}

\begin{tabular}{|c|c|c|c|c|c|c|}
\hline TICKER & $\underline{\text { NAME }}$ & $\begin{array}{l}\text { TOTAL } \\
\text { RETURN } \\
\end{array}$ & $\underline{\text { BETA }}$ & $\begin{array}{l}\text { SE } \\
\text { BETA }\end{array}$ & $\begin{array}{c}\text { R- } \\
\text { SQUARED }\end{array}$ & $\begin{array}{c}\text { VARIANCE } \\
\text { (ER) }\end{array}$ \\
\hline CUV & CUVIER MINES INC. J & 0.034 & 1.923 & 0.567 & 0.163 & 0.05438 \\
\hline CXA.A & CONSOLIDATED HCI HOLDING & 0.021 & 1.206 & 0.466 & 0.102 & 0.03429 \\
\hline $\mathrm{CXY}$ & CANADIAN OCCIDENTAL PETR & 0.024 & 1.354 & 0.367 & 0.188 & 0.02344 \\
\hline $\mathrm{CZR}$ & CZAR RESOURCES LTD. & 0.003 & 1.673 & 0.327 & 0.307 & 0.02185 \\
\hline $\mathrm{CZZ}$ & CONSOLIDATED TALCORP LTD & -0.020 & 0.748 & 0.288 & 0.106 & 0.01295 \\
\hline DEN.A & DENISON MINES LTD. CL'A & -0.006 & 1.519 & 0.256 & 0.377 & 0.01488 \\
\hline DFS & DOFASCO INC. & 0.019 & 1.255 & 0.151 & 0.544 & 0.00704 \\
\hline $\mathrm{DHC}$ & DONOHUE INC. & 0.021 & 0.574 & 0.218 & 0.126 & 0.00658 \\
\hline DLX & DYLEX LTD. & 0.054 & 1.222 & 0.460 & 0.107 & 0.03349 \\
\hline DLX.A & DYLEX LTD. 'A' PR & 0.044 & 1.271 & 0.407 & 0.142 & 0.02735 \\
\hline DML.A & DICKENSON MINES LTD. CL & 0.022 & 1.907 & 0.344 & 0.343 & 0.02544 \\
\hline DML.B & DICKENSON MINES LTD. CL & 0.022 & 1.167 & 0.333 & 0.172 & 0.01894 \\
\hline DMN & DOMINION EXPLORERS INC. & -0.008 & 1.975 & 0.420 & 0.276 & 0.03444 \\
\hline DMP & DOME PETROLEUM LTD. & -0.010 & 1.522 & 0.344 & 0.249 & 0.02232 \\
\hline DNA & DYNAMAR ENERGY LTD. & -0.020 & 2.041 & 0.548 & 0.191 & 0.05245 \\
\hline DOM.A & DOMAN INDUSTRIES LTD. CL & 0.030 & 1.369 & 0.336 & 0.226 & 0.02057 \\
\hline DPL.A & DYNEX PETROLEUM LTD. CL & 0.000 & 1.321 & 0.641 & 0.067 & 0.06226 \\
\hline DPR & DUNDEE-PALLISER RESOURCE & 0.046 & 1.118 & 0.500 & 0.078 & 0.03841 \\
\hline DSW & DISCOVERY WEST CORP. & -0.004 & 1.722 & 0.329 & 0.317 & 0.02244 \\
\hline DTC & DOMTAR INC. & 0.022 & 1.393 & 0.167 & 0.541 & 0.00860 \\
\hline DTX & DOMINION TEXTILE INC. & 0.009 & 0.806 & 0.198 & 0.219 & 0.00712 \\
\hline DUP.A & DUPONT CANADA INC. CL'A & 0.036 & 0.997 & 0.181 & 0.340 & 0.00701 \\
\hline $\mathrm{DXH}$ & DEXLEIGH CORP. J & 0.037 & 1.325 & 0.493 & 0.111 & 0.03778 \\
\hline EAV.A & VINER HOLDINGS LTD. E.A. & 0.003 & 1.881 & 0.414 & 0.259 & 0.03279 \\
\hline $\mathrm{EC}$ & ECO CORPORATION & 0.086 & 0.530 & 1.066 & 0.005 & 0.15467 \\
\hline $\mathrm{ECI}$ & ENCOR ENERGY CORP. INC. & 0.018 & 1.241 & 0.256 & 0.286 & 0.01294 \\
\hline EEI & EXCEL ENERGY INC. J & 0.004 & 2.128 & 0.512 & 0.227 & 0.04795 \\
\hline EGO & EGO RESOURCES LTD. J & 0.054 & 2.274 & 0.687 & 0.157 & 0.07917 \\
\hline EKS & ELKS INC. & 0.012 & 0.140 & 0.259 & 0.006 & 0.00819 \\
\hline EL.X & ELECTROHOME LTD. CL 'X' & 0.011 & 0.573 & 0.390 & 0.035 & 0.02236 \\
\hline EL.Y & ELECTROHOME LTD. CL 'Y' & 0.009 & 0.496 & 0.397 & 0.026 & 0.02293 \\
\hline ELF & E-L FINANCIAL CORP. LTD. & 0.032 & 0.638 & 0.219 & 0.125 & 0.00779 \\
\hline EML & EMCO LTD. & 0.015 & 0.617 & 0.137 & 0.257 & 0.00355 \\
\hline EMP.A & EMPIRE COMPANY LTD. CL & 0.038 & 0.851 & 0.227 & 0.192 & 0.00903 \\
\hline
\end{tabular}


TABLE 5-34 (Continued)

\begin{tabular}{|c|c|c|c|c|c|c|}
\hline TICKER & $\underline{\text { NAME }}$ & $\begin{array}{l}\text { TOTAL } \\
\text { RETURN } \\
\end{array}$ & $\underline{\text { BETA }}$ & $\begin{array}{l}\text { SE } \\
\text { BETA }\end{array}$ & $\begin{array}{c}\text { R- } \\
\text { SQUARED }\end{array}$ & $\begin{array}{c}\text { TUIAL } \\
\text { VARIANCE } \\
\text { (ER) } \\
\end{array}$ \\
\hline ERG & ERG RESOURCES INC. J & 0.045 & 1.751 & 0.494 & 0.175 & 0.04196 \\
\hline EXL & EXALL RESOURCES LTD. J & 0.009 & 1.294 & 0.440 & 0.130 & 0.03147 \\
\hline $\mathrm{FC}$ & FCA INTERNATIONAL LTD. & 0.014 & 1.043 & 0.193 & 0.330 & 0.00790 \\
\hline FCY & FIRST CITY FINANCIAL COR & 0.020 & 0.716 & 0.185 & 0.202 & 0.00608 \\
\hline FIL.A & FEDERAL INDUSTRIES LTD. & 0.024 & 0.530 & 0.190 & 0.121 & 0.00317 \\
\hline FMC & FORD MOTOR CO. OF CANADA & 0.024 & 0.680 & 0.205 & 0.156 & 0.00708 \\
\hline FMR & FLANAGAN MCADAM RESOURCE & 0.059 & 1.118 & 0.625 & 0.052 & 0.05828 \\
\hline FNG & FIRAN CORP. & 0.014 & 1.547 & 0.338 & 0.261 & 0.02195 \\
\hline FTT & FINNING LTD. & 0.021 & 1.018 & 0.239 & 0.239 & 0.01060 \\
\hline GAN & GANDALF TECHNOLOGIES INC & -0.011 & 0.899 & 0.266 & 0.162 & 0.01197 \\
\hline GB & G \& B AUTOMATED EQUIPMEN & 0.004 & 0.921 & 0.389 & 0.087 & 0.02340 \\
\hline GBM & GIBRALTAR MINES LTD. & 0.008 & 1.477 & 0.269 & 0.338 & 0.01547 \\
\hline GDS.A & GENDIS INC. CL'A' & 0.018 & 0.648 & 0.202 & 0.148 & 0.00680 \\
\hline GFG & GRAFTON GROUP LTD. & 0.018 & 1.061 & 0.209 & 0.303 & 0.00890 \\
\hline GFG.A & GRAFTON GROUP LTD. CL'A & 0.016 & 1.219 & 0.190 & 0.410 & 0.00869 \\
\hline GFI & GREYHOUND COMPUTER OF CA & 0.032 & 1.213 & 0.239 & 0.304 & 0.01161 \\
\hline GHL & GREYHOUND LINES OF CANAD & 0.003 & 0.625 & 0.143 & 0.245 & 0.00382 \\
\hline GL & GREAT LAKES FOREST PRODU & 0.025 & 1.066 & 0.190 & 0.348 & 0.00782 \\
\hline GLI & GRANDMA LEE'S INC. & -0.030 & 0.544 & 0.486 & 0.022 & 0.03378 \\
\hline GM & GENERAL MOTORS CORP. & 0.012 & 0.838 & 0.167 & 0.306 & 0.00528 \\
\hline GMQ & GEOMAQUE EXPLORATIONS LT & 0.062 & 1.688 & 0.753 & 0.080 & 0.08669 \\
\hline GSW.A & GSW INC. CL'A' & 0.032 & 0.603 & 0.274 & 0.078 & 0.01129 \\
\hline GSW.B & GSW INC. CL 'B' SV & 0.030 & 0.586 & 0.230 & 0.099 & 0.00828 \\
\hline GT & GOODYEAR CANADA INC. & 0.018 & 0.485 & 0.212 & 0.081 & 0.00694 \\
\hline GTL & GREAT LAKES NICKEL LTD. & 0.014 & 0.356 & 0.432 & 0.011 & 0.02672 \\
\hline GUR & GULFSTREAM RESOURCES CAN & -0.003 & 1.802 & 0.444 & 0.219 & 0.03563 \\
\hline GWS.A & GREAT WEST STEEL INDUSTR & 0.021 & 0.869 & 0.437 & 0.063 & 0.02884 \\
\hline HAY & HAYES-DANA INC. & 0.015 & 0.473 & 0.223 & 0.071 & 0.00757 \\
\hline $\mathrm{HBC}$ & HUDSON'S BAY CO. & 0.006 & 0.738 & 0.166 & 0.251 & 0.00520 \\
\hline HBM.S & HUDSON BAY MINING \& SMEL & -0.003 & 1.698 & 0.265 & 0.414 & 0.01698 \\
\hline HCG.B & HOME CAPITAL GROUP CLASS & 0.049 & 1.208 & 0.658 & 0.055 & 0.06486 \\
\hline $\mathrm{HFD}$ & HALIFAX DEVELOPMENTS LTD & 0.041 & 0.182 & 0.236 & 0.010 & 0.00795 \\
\hline HIL & HEES INTERNATIONAL CORP. & 0.016 & 0.783 & 0.210 & 0.191 & 0.00771 \\
\hline HLE & HALE RESOURCES LTD. J & 0.022 & 0.813 & 0.847 & 0.016 & 0.10018 \\
\hline
\end{tabular}


TABLE 5-34 (Continued)

\begin{tabular}{|c|c|c|c|c|c|c|}
\hline TICKER & NAME & $\begin{array}{l}\text { TOTAL } \\
\text { RETURN } \\
\end{array}$ & BETA & $\begin{array}{l}\text { SE } \\
\text { BETA }\end{array}$ & $\begin{array}{c}\text { R- } \\
\text { SQUARED } \\
\end{array}$ & $\begin{array}{c}\text { VARIANCE } \\
\text { (ER) }\end{array}$ \\
\hline HLY & HALEY INDUSTRIES LTD. & 0.021 & 0.835 & 0.264 & 0.145 & 0.01153 \\
\hline HSC & HAWKER SIDDELEY CANADA I & 0.012 & 0.975 & 0.151 & 0.415 & 0.00549 \\
\hline HSG.A & HARRIS STEEL GROUP INC. & 0.029 & 0.907 & 0.258 & 0.174 & 0.01138 \\
\hline HSG.B & HARRIS STEEL GROUP INC. & 0.029 & 0.307 & 0.304 & 0.017 & 0.01330 \\
\hline HSM & HORSHAM CORP. SV & 0.011 & 1.432 & 0.474 & 0.134 & 0.03668 \\
\hline HWD & HIGHWOOD RESOURCES LTD. & 0.018 & 1.595 & 0.346 & 0.264 & 0.02309 \\
\hline ICG & INTER-CITY GAS CORP. & 0.009 & 0.897 & 0.168 & 0.326 & 0.00592 \\
\hline ICL & INDAL LTD. & 0.023 & 0.827 & 0.211 & 0.206 & 0.00796 \\
\hline IES & INVERNESS PETROLEUM LTD. & 0.008 & 1.497 & 0.265 & 0.351 & 0.01534 \\
\hline ILL & INTERNATIONAL LARDER MIN & 0.019 & 1.075 & 0.534 & 0.064 & 0.04312 \\
\hline IMO.A & IMPERIAL OIL LTD. CL 'A' & 0.018 & 1.315 & 0.156 & 0.556 & 0.00769 \\
\hline IMS & IMASCO LTD. & 0.015 & 0.765 & 0.165 & 0.273 & 0.00529 \\
\hline ING & INGLIS LTD. & 0.033 & 0.743 & 0.232 & 0.148 & 0.00897 \\
\hline INL & INLAND NATURAL GAS CO. L & 0.014 & 0.364 & 0.132 & 0.114 & 0.00278 \\
\hline IPL & INTERPROVINCIAL PIPE LIN & 0.016 & 0.737 & 0.129 & 0.357 & 0.00366 \\
\hline IPN & INTERNATIONAL PLATINUM C & 0.065 & 2.108 & 0.685 & 0.138 & 0.07703 \\
\hline IRI & INCA RESOURCES INC. J & 0.004 & 1.784 & 0.486 & 0.186 & 0.04111 \\
\hline ISE & INTERNATIONAL SEMI-TECH & 0.002 & 0.082 & 0.565 & 0.000 & 0.04386 \\
\hline ISP & IPSCO INC. & 0.015 & 0.901 & 0.252 & 0.178 & 0.01095 \\
\hline ITL & I.T.L. INDUSTRIES LTD. & 0.053 & 1.775 & 0.630 & 0.118 & 0.06377 \\
\hline ITO & INTERNATIONAL THOMSON OR & 0.020 & 1.139 & 0.152 & 0.493 & 0.00641 \\
\hline IVA.A & IVACO INC. CL'A' SV & 0.010 & 1.261 & 0.236 & 0.326 & 0.01168 \\
\hline IWT & IRWIN TOY LTD. VT & 0.000 & 0.740 & 0.300 & 0.093 & 0.01409 \\
\hline IWT.A & IRWIN TOY LTD. NV & -0.002 & 0.630 & 0.300 & 0.070 & 0.01367 \\
\hline JFR & JAMIE FRONTIER RESOURCES & -0.020 & 1.143 & 0.475 & 0.089 & 0.03506 \\
\hline $\mathrm{JN}$ & JANNOCK LTD. & 0.040 & 1.427 & 0.278 & 0.316 & 0.00875 \\
\hline IPJ & J-Q RESOURCES INC. J & 0.072 & 2.989 & 0.841 & 0.177 & 0.12144 \\
\hline JTL & JOUTEL RESOURCES LTD. SV & 0.004 & 1.242 & 0.541 & 0.082 & 0.04514 \\
\hline KER & KERR ADDISON MINES LTD. & 0.013 & 1.069 & 0.253 & 0.233 & 0.01178 \\
\hline KEY & KEY ANACON MINES LTD. J & 0.008 & 1.368 & 0.381 & 0.179 & 0.02503 \\
\hline $\mathrm{KKL}$ & KAM-KOTIA MINES LTD. & 0.008 & 1.668 & 0.315 & 0.323 & 0.02070 \\
\hline $\mathrm{L}$ & LOBLAW COMPANIES LTD. & 0.017 & 0.739 & 0.139 & 0.323 & 0.00405 \\
\hline LAC & LAC MINERALS LTD. & 0.047 & 1.697 & 1.041 & 0.045 & 0.08784 \\
\hline LBT & LABATT, JOHN LTD. & 0.020 & 0.650 & 0.154 & 0.236 & 0.00438 \\
\hline
\end{tabular}




\section{TABLE 5-34 (Continued)}

\begin{tabular}{|c|c|c|c|c|c|c|}
\hline TICKER & $\underline{\text { NAME }}$ & $\begin{array}{l}\text { TOTAL } \\
\text { RETURN } \\
\end{array}$ & $\underline{\text { BETA }}$ & $\underset{\text { BETA }}{\text { SE }}$ & $\begin{array}{c}\text { R- } \\
\text { SQUARED }\end{array}$ & $\begin{array}{c}\text { VARIANCE } \\
\text { (ER) }\end{array}$ \\
\hline LDM.A & LAIDLAW TRANSPORTATION L & 0.044 & 0.905 & 0.198 & 0.262 & 0.00751 \\
\hline LDM.B & LAIDLAW TRANSPORTATION L & 0.044 & 0.989 & 0.167 & 0.373 & 0.00629 \\
\hline LHI & LEIGH INSTRUMENTS LTD. & 0.011 & 0.876 & 0.257 & 0.164 & 0.01122 \\
\hline $\mathrm{CMC}$ & LAMBDA MERCANTILE CORP. & 0.068 & 0.774 & 0.649 & 0.025 & 0.05620 \\
\hline LMK & LANDMARK CORP. SV & -0.015 & 1.439 & 0.396 & 0.188 & 0.02524 \\
\hline LTL & LYTTON MINERALS LTD. J & 0.029 & 0.664 & 0.692 & 0.015 & 0.06882 \\
\hline LUM & LUMONICS INC. & -0.005 & 1.003 & 0.221 & 0.259 & 0.00932 \\
\hline LUR & LAURASIA RESOURCES LTD. & 0.020 & 1.288 & 0.570 & 0.080 & 0.04999 \\
\hline LVA & LAVA CAPITAL CORP. J & -0.008 & 1.070 & 0.572 & 0.056 & 0.04901 \\
\hline LYX & LYNX-CANADA EXPLORATIONS & 0.003 & 0.639 & 0.548 & 0.022 & 0.04356 \\
\hline $\mathrm{MB}$ & MACMILLAN BLOEDEL LTD. & 0.025 & 1.332 & 0.207 & 0.411 & 0.01034 \\
\hline $\mathrm{MCL}$ & MOORE CORP. LTD. & 0.015 & 0.570 & 0.184 & 0.144 & 0.00306 \\
\hline MCS & MCCHIP RESOURCES INC. & 0.010 & 0.815 & 0.343 & 0.087 & 0.01825 \\
\hline ME & MONETA PORCUPINE MINES I & 0.011 & 1.394 & 0.550 & 0.112 & 0.04620 \\
\hline MEC & MARITIME ELECTRIC COMPAN & 0.041 & 0.371 & 0.576 & 0.007 & 0.04734 \\
\hline MET & METALORE RESOURCES LTD. & 0.060 & 1.811 & 0.445 & 0.219 & 0.03596 \\
\hline MG.A & MAGNA INTERNATIONAL INC. & 0.027 & 0.738 & 0.350 & 0.072 & 0.01022 \\
\hline MGI & MAGNETICS INTERNATIONAL & 0.043 & 0.866 & 0.520 & 0.045 & 0.04008 \\
\hline MHG.A & MDS HEALTH GROUP LTD. CL & 0.023 & 0.660 & 0.192 & 0.166 & 0.00629 \\
\hline MHG.B & MDS HEALTH GROUP LTD. CL & 0.021 & 0.669 & 0.212 & 0.145 & 0.00742 \\
\hline MHP.X & MACLEAN HUNTER LTD. CL' & 0.024 & 0.886 & 0.121 & 0.475 & 0.00396 \\
\hline MHP.Y & MACLEAN HUNTER LTD. CL' & 0.033 & 0.788 & 0.330 & 0.088 & 0.01690 \\
\hline MIV & MICC INVESTMENTS LTD. & 0.022 & 1.156 & 0.459 & 0.097 & 0.03305 \\
\hline $\mathrm{MKC}$ & MARK RESOURCES INC. & 0.004 & 1.132 & 0.267 & 0.237 & 0.01321 \\
\hline $\mathrm{MKF}$ & MACKENZIE FINANCIAL CORP & 0.066 & 2.417 & 0.550 & 0.247 & 0.05677 \\
\hline MKI & M-CORP INC. & 0.059 & 0.982 & 0.336 & 0.127 & 0.01828 \\
\hline ML & MAPLE LEAF GARDENS LTD. & 0.035 & 0.213 & 0.222 & 0.015 & 0.00709 \\
\hline MLT & MITEL CORP. & -0.031 & 1.586 & 0.301 & 0.321 & 0.01882 \\
\hline $\mathrm{MN}$ & MADELEINE MINES LTD. J & 0.070 & 0.970 & 0.567 & 0.047 & 0.04770 \\
\hline MOF & MOFFAT COMMUNICATIONS LT & 0.008 & 0.419 & 0.185 & 0.081 & 0.00528 \\
\hline MOL.A & MOLSON COMPANIES LTD. & 0.009 & 0.735 & 0.158 & 0.267 & 0.00485 \\
\hline MOL.B & MOLSON COMPANIES LTD. & 0.011 & 0.519 & 0.175 & 0.130 & 0.00498 \\
\hline MPG & MPG INVESTMENT CORP. LTD & 0.021 & 0.268 & 0.333 & 0.012 & 0.01537 \\
\hline MRI & MINERAL RESOURCES INTERN & 0.017 & 1.357 & 0.250 & 0.333 & 0.01326 \\
\hline
\end{tabular}




\section{TABLE 5-34 (Continued)}

\begin{tabular}{|c|c|c|c|c|c|c|}
\hline TICKER & $\underline{\text { NAME }}$ & $\begin{array}{l}\text { TOTAL } \\
\text { RETURN }\end{array}$ & $\underline{\text { BETA }}$ & $\begin{array}{l}\text { SE } \\
\text { BETA }\end{array}$ & $\begin{array}{l}\text { R- } \\
\text { SQUARED }\end{array}$ & $\begin{array}{c}\text { VARIANCE } \\
\text { (ER) }\end{array}$ \\
\hline MRP & MORRISON PETROLEUMS LTD. & 0.042 & 1.758 & 0.378 & 0.268 & 0.02767 \\
\hline MTT & MARITIME TELEGRAPH \& TEL & 0.015 & 0.476 & 0.110 & 0.240 & 0.00226 \\
\hline MTU & MONTREAL TRUSTCO INC. & 0.028 & 1.067 & 0.230 & 0.271 & 0.01021 \\
\hline MV & MENTOR EXPLORATION \& DEV & 0.016 & 0.652 & 0.319 & 0.066 & 0.01543 \\
\hline MVA & MINNOVA INC. & 0.010 & 1.639 & 0.209 & 0.512 & 0.01260 \\
\hline NA & NATIONAL BANK OF CANADA & 0.021 & 1.011 & 0.138 & 0.477 & 0.00514 \\
\hline NAG & NOR-ACME GOLD MINES LTD. & 0.014 & 0.378 & 0.466 & 0.011 & 0.03114 \\
\hline NBC & N.B. COOK CORP. LTD. & 0.000 & 0.464 & 0.391 & 0.023 & 0.02213 \\
\hline NBE & NOVA BEAUCAGE MINES LTD. & 0.064 & 1.855 & 0.601 & 0.139 & 0.05934 \\
\hline NCC.A & NEWFOUNDLAND CAPITAL COR & 0.007 & 0.746 & 0.289 & 0.102 & 0.01315 \\
\hline NCN & NORCEN ENERGY RESOURCES & 0.014 & 1.076 & 0.223 & 0.294 & 0.00880 \\
\hline NEL & NEWTEL ENTERPRISES LTD. & 0.013 & 0.333 & 0.113 & 0.131 & 0.00208 \\
\hline NEN & NORTHSTAR ENERGY CORP. & 0.015 & 1.336 & 0.448 & 0.133 & 0.03199 \\
\hline NGX & NORTHGATE EXPLORATION LT & 0.009 & 1.967 & 0.254 & 0.505 & 0.01838 \\
\hline NHA & NAHANNI MINES LTD. J & 0.058 & -0.256 & 0.655 & 0.003 & 0.06059 \\
\hline NHD.A & NEW HARDING GROUP INC. & 0.032 & 1.221 & 0.390 & 0.144 & 0.02421 \\
\hline NHD.B & NEW HARDING GROUP INC. & 0.031 & 0.690 & 0.365 & 0.058 & 0.01923 \\
\hline NIK & NICKEL RIM MINES LTD. J & 0.028 & 1.134 & 0.636 & 0.051 & 0.06033 \\
\hline NKL & NEW KELORE MINES LTD. J & 0.021 & 0.703 & 0.546 & 0.027 & 0.04344 \\
\hline NLX & NORLEX MINES LTD. J & 0.042 & 1.646 & 0.646 & 0.099 & 0.06548 \\
\hline NMA.A & NOMA INDUSTRIES LTD. CL & 0.054 & 1.499 & 0.251 & 0.377 & 0.01430 \\
\hline NMC & NUMAC OIL \& GAS LTD. & 0.010 & 1.338 & 0.224 & 0.376 & 0.01142 \\
\hline NOL & NORTHLAND OILS LTD. J & 0.001 & 1.233 & 0.331 & 0.190 & 0.01914 \\
\hline NOM & NORBEAU MINES INC. J & 0.024 & 1.345 & 0.699 & 0.059 & 0.07355 \\
\hline NOR & NORANDA INC. & 0.014 & 1.783 & 0.196 & 0.592 & 0.01325 \\
\hline NPD & NEW PROVIDENCE DEVELOPME & 0.022 & 0.609 & 0.412 & 0.036 & 0.02495 \\
\hline NPT & NATIONAL PETROLEUM CORP. & 0.028 & 1.525 & 0.673 & 0.080 & 0.06975 \\
\hline NQR & NEW QUEBEC RAGLAN MINES & 0.009 & 1.148 & 0.312 & 0.186 & 0.01698 \\
\hline NR & NUFORT RESOURCES INC. J & 0.017 & 0.012 & 0.537 & 0.000 & 0.04089 \\
\hline NSP & NATIONAL SEA PRODUCTS LT & 0.022 & 0.584 & 0.315 & 0.057 & 0.01475 \\
\hline NSP.A & NATIONAL SEA PRODUCTS LT & 0.009 & 0.745 & 0.310 & 0.112 & 0.01370 \\
\hline NSR & NSR RESOURCES INC. J & 0.025 & 1.183 & 0.514 & 0.082 & 0.04068 \\
\hline NTL & NORTHERN TELECOM LTD. & 0.011 & 1.146 & 0.201 & 0.354 & 0.00889 \\
\hline NUB & NORTHUMBERLAND MINES LTD & 0.044 & 1.533 & 0.634 & 0.093 & 0.05810 \\
\hline
\end{tabular}




\section{TABLE 5-34 (Continued)}

\begin{tabular}{|c|c|c|c|c|c|c|}
\hline TICKER & $\underline{\text { NAME }}$ & $\begin{array}{l}\text { AVERAGE } \\
\text { TOTAL } \\
\text { RETURN }\end{array}$ & BETA & $\begin{array}{l}\text { SE } \\
\text { BETA }\end{array}$ & $\begin{array}{c}\text { R- } \\
\text { SQUARED }\end{array}$ & $\begin{array}{c}\text { TOTAL } \\
\text { VARIANCE } \\
\text { (ER) } \\
\end{array}$ \\
\hline NUW & NU-WEST GROUP LTD. & -0.034 & 1.388 & 0.678 & 0.066 & 0.06978 \\
\hline NUW.A & NU-WEST GROUP LTD. CL 'A & -0.023 & 1.643 & 0.420 & 0.206 & 0.03142 \\
\hline NVA & NOVA, AN ALBERTA CORPORA & 0.011 & 0.940 & 0.216 & 0.244 & 0.00869 \\
\hline NWS & NOWSCO WELL SERVICE LTD. & 0.003 & 1.227 & 0.284 & 0.241 & 0.01500 \\
\hline OAK & OAKWOOD PETROLEUMS LTD. & 0.011 & 1.072 & 0.530 & 0.066 & 0.04072 \\
\hline OIL.B & OCELOT INDUSTRIES LTD. C & 0.006 & 1.057 & 0.474 & 0.078 & 0.03449 \\
\hline $\mathrm{OMH}$ & OMEGA HYDROCARBONS LTD. & -0.001 & 1.369 & 0.252 & 0.334 & 0.01346 \\
\hline OSH.A & OSHAWA GROUP LTD. (THE) & 0.023 & 0.399 & 0.151 & 0.106 & 0.00360 \\
\hline OSS & OSISKO LAKE MINES LTD. J & 0.034 & 0.506 & 0.646 & 0.011 & 0.03263 \\
\hline OTX & OILTEX INTERNATIONAL LTD & 0.005 & 0.411 & 0.510 & 0.011 & 0.03729 \\
\hline PAM & PAMOUR INC. & 0.009 & 1.457 & 0.445 & 0.158 & 0.01821 \\
\hline PCI & PCL INDUSTRIES LTD. & 0.019 & 1.419 & 0.295 & 0.282 & 0.01713 \\
\hline PCP & PANCANADIAN PETROLEUM LT & 0.009 & 1.142 & 0.198 & 0.361 & 0.00865 \\
\hline PDG & PLACER DEVELOPMENT LTD. & 0.017 & 1.755 & 0.200 & 0.570 & 0.01317 \\
\hline PGC.A & PAGURIAN CORP. LTD. (THE & 0.028 & 1.392 & 0.206 & 0.437 & 0.01064 \\
\hline PGE & PAGE PETROLEUM LTD. & -0.037 & 1.694 & 0.543 & 0.142 & 0.04863 \\
\hline PGI & PROVIGO INC. & 0.021 & 0.865 & 0.174 & 0.295 & 0.00608 \\
\hline PLG.A & PLACE RESOURCES CORP. CL & -0.004 & 0.923 & 0.305 & 0.137 & 0.01520 \\
\hline EAT.A & PENNANT RESOURCES LTD. J & 0.003 & -0.148 & 0.663 & 0.001 & 0.03863 \\
\hline POC & POCO PETROLEUMS LTD. & 0.030 & 0.914 & 0.268 & 0.164 & 0.01220 \\
\hline POW & POWER CORP. OF CANADA SV & 0.029 & 1.094 & 0.147 & 0.483 & 0.00595 \\
\hline POY & PRAIRIE OIL ROYALTIES CO & 0.008 & 0.682 & 0.288 & 0.104 & 0.01257 \\
\hline PPL & PEMBINA RESOURCES LTD. & 0.018 & 0.445 & 0.240 & 0.055 & 0.00862 \\
\hline PPT & PINE POINT MINES LTD. & -0.002 & 0.644 & 0.348 & 0.055 & 0.01810 \\
\hline PRG & PEERLESS CARPET CORP. & 0.030 & 0.537 & 0.305 & 0.050 & 0.01389 \\
\hline PTX & PACIFIC TRANS-OCEAN RESO & 0.040 & 1.564 & 0.447 & 0.177 & 0.03406 \\
\hline PWT & PENN WEST PETROLEUM LTD. & 0.015 & 0.578 & 0.586 & 0.017 & 0.02699 \\
\hline QT & QUEBEC-TELEPHONE & 0.018 & 0.341 & 0.116 & 0.127 & 0.00220 \\
\hline QTR & QUEENSTAKE RESOURCES LTD & -0.008 & 0.912 & 0.369 & 0.094 & 0.02132 \\
\hline RAX & RIO ALTO EXPLORATION LTD & 0.008 & 1.780 & 0.532 & 0.159 & 0.04770 \\
\hline RAY & RAYROCK YELLOW KNIFE RESO & 0.003 & 1.190 & 0.285 & 0.228 & 0.01489 \\
\hline RCI.A & ROGERS COMMUNICATIONS IN & 0.023 & 1.398 & 0.292 & 0.279 & 0.01678 \\
\hline RCI.B & ROGERS COMMUNICATIONS IN & 0.023 & 1.327 & 0.326 & 0.220 & 0.01922 \\
\hline RET.A & REITMAN'S (CANADA) LTD. & 0.025 & 0.534 & 0.282 & 0.058 & 0.01190 \\
\hline
\end{tabular}


TABLE 5-34 (Continued)

\begin{tabular}{|c|c|c|c|c|c|c|}
\hline TICKER & $\underline{\text { NAME }}$ & $\begin{array}{l}\text { TOTAL } \\
\text { RETURN }\end{array}$ & BETA & $\begin{array}{l}\text { SE } \\
\text { BETA }\end{array}$ & $\begin{array}{c}\text { R- } \\
\text { SQUARED }\end{array}$ & $\begin{array}{c}\text { VARIANCE } \\
\text { (ER) }\end{array}$ \\
\hline RGM & ROYEX GOLD MINING CORP. & 0.020 & 1.165 & 0.406 & 0.122 & 0.02658 \\
\hline RGO & RANGER OIL LTD. & 0.006 & 1.257 & 0.275 & 0.261 & 0.01451 \\
\hline RIN & REDPATH INDUSTRIES LTD. & 0.039 & 0.859 & 0.223 & 0.201 & 0.00880 \\
\hline RL.A & ROLLAND INC. CL'A' NV & 0.031 & 0.773 & 0.214 & 0.181 & 0.00792 \\
\hline $\mathrm{RMN}$ & ROMAN CORP. LTD. & 0.008 & 1.696 & 0.269 & 0.402 & 0.01715 \\
\hline $\mathrm{ROC}$ & ROTHMANS INC. & 0.027 & 0.601 & 0.245 & 0.093 & 0.00934 \\
\hline ROM & RIO ALGOM LTD. & 0.012 & 0.992 & 0.202 & 0.290 & 0.00814 \\
\hline RPC.A & REVENUE PROPERTIES LTD. & 0.020 & 0.686 & 0.258 & 0.107 & 0.01057 \\
\hline RPC.B & REVENUE PROPERTIES LTD. & 0.029 & 0.931 & 0.364 & 0.100 & 0.02080 \\
\hline RPL & RAM PETROLEUMS LTD. & -0.002 & 0.743 & 0.326 & 0.081 & 0.01635 \\
\hline RR & REDSTONE RESOURCES INC. & 0.009 & 1.655 & 0.502 & 0.155 & 0.04225 \\
\hline RSS.S & REED STENHOUSE COMPANIES & 0.025 & 0.884 & 0.342 & 0.103 & 0.01782 \\
\hline RY & ROYAL BANK OF CANADA (TH & 0.007 & 0.620 & 0.133 & 0.269 & 0.00343 \\
\hline RYL.A & ROYAL TRUSTCO LTD. CL 'A & 0.013 & 0.740 & 0.281 & 0.105 & 0.01250 \\
\hline SBG.A & STEINBERG INC. CL 'A' NV & 0.016 & 0.794 & 0.182 & 0.243 & 0.00622 \\
\hline SCC & SEARS CANADA INC. & 0.014 & 1.001 & 0.192 & 0.320 & 0.00755 \\
\hline SCD & SCHNEIDER CORP. & 0.017 & 0.133 & 0.179 & 0.010 & 0.00414 \\
\hline SCD.A & SCHNEIDER CORP. CL 'A' N & 0.018 & 0.225 & 0.225 & 0.017 & 0.00732 \\
\hline SCR & SCURRY-RAINBOW OIL LTD. & 0.010 & 0.830 & 0.254 & 0.153 & 0.01080 \\
\hline SCT & SCINTREX LTD. & 0.007 & 0.750 & 0.348 & 0.073 & 0.01845 \\
\hline SE & SHERRITT GORDON MINES LT & 0.001 & 1.439 & 0.241 & 0.377 & 0.01318 \\
\hline SEV & SIMCOE ERIE INVESTORS LT & 0.021 & 0.640 & 0.248 & 0.101 & 0.00970 \\
\hline SHK & SHL SYSTEMHOUSE INC. & 0.041 & 0.613 & 0.614 & 0.018 & 0.02838 \\
\hline SIA & SHELTER OIL \& GAS LTD. J & -0.008 & 1.460 & 0.483 & 0.134 & 0.03814 \\
\hline SKH.A & SELKIRK COMMUNICATIONS L & 0.019 & 0.842 & 0.188 & 0.253 & 0.00672 \\
\hline SLP & SCINTILORE EXPLORATIONS & 0.094 & 1.309 & 0.828 & 0.041 & 0.10126 \\
\hline SMO & SANTA MARIA RESOURCES LT & 0.028 & 1.236 & 0.753 & 0.044 & 0.08388 \\
\hline SPL & SCOTT PAPER LTD. & 0.030 & 0.613 & 0.140 & 0.246 & 0.00366 \\
\hline SPZ & SPAR AEROSPACE LTD. SV & 0.005 & 1.200 & 0.198 & 0.383 & 0.00903 \\
\hline SR & STEEP ROCK RESOURCES INC & 0.007 & 0.764 & 0.365 & 0.069 & 0.02029 \\
\hline SRC & SCOTT'S HOSPITALITY INC. & 0.026 & 0.992 & 0.166 & 0.378 & 0.00624 \\
\hline SRC.C & SCOTT'S HOSPITALITY INC. & 0.028 & 1.012 & 0.152 & 0.428 & 0.00574 \\
\hline SRH & STRATHCONA RESOURCES IND & 0.015 & 0.879 & 0.419 & 0.069 & 0.02675 \\
\hline SRL & SCEPTRE RESOURCES LTD. & -0.003 & 1.155 & 0.274 & 0.232 & 0.01380 \\
\hline
\end{tabular}




\section{TABLE 5-34 (Continued)}

\begin{tabular}{|c|c|c|c|c|c|c|}
\hline TICKER & NAME & $\begin{array}{l}\text { TOTAL } \\
\text { RETURN } \\
\end{array}$ & BETA & $\begin{array}{l}\text { SE } \\
\text { BETA }\end{array}$ & $\begin{array}{c}\text { R- } \\
\text { SQUARED }\end{array}$ & $\begin{array}{c}\text { TUTAL } \\
\text { VARIANCE } \\
\text { (ER) }\end{array}$ \\
\hline SRN.A & STRATHEARN HOUSE GROUP L & 0.032 & 1.194 & 0.615 & 0.060 & 0.05697 \\
\hline HRT & SCARBORO RESOURCES LTD. & -0.018 & 0.224 & 0.750 & 0.002 & 0.04357 \\
\hline SSD & SDC SYDNEY DEVELOPMENT C & -0.034 & 1.398 & 0.691 & 0.066 & 0.07183 \\
\hline SSI.A & SLATER INDUSTRIES INC. C & 0.008 & 0.784 & 0.219 & 0.184 & 0.00823 \\
\hline STE.A & STELCO INC. SERIES 'A' & 0.008 & 0.959 & 0.177 & 0.333 & 0.00663 \\
\hline STM & SOUTHAM INC. & 0.025 & 0.660 & 0.285 & 0.086 & 0.00689 \\
\hline STU & STUART D.A. LTD. & 0.039 & -0.302 & 0.229 & 0.032 & 0.00702 \\
\hline SUD & SUDBURY CONTACT MINES LT & 0.032 & 0.994 & 0.533 & 0.056 & 0.04259 \\
\hline SYH & SCOTTISH \& YORK HOLDINGS & 0.013 & 0.906 & 0.459 & 0.062 & 0.03179 \\
\hline TAU.A & TRANSALTA UTILITIES CORP & 0.012 & 0.138 & 0.115 & 0.024 & 0.00191 \\
\hline TBR & TURBO RESOURCES LTD. & 0.016 & 1.184 & 0.432 & 0.115 & 0.02983 \\
\hline TD & TORONTO-DOMINION BANK (T & 0.018 & 0.771 & 0.133 & 0.364 & 0.00392 \\
\hline TDE & TRANS-DOMINION ENERGY CO & 0.002 & 1.073 & 0.463 & 0.085 & 0.03190 \\
\hline TEK.B & TECK CORP. CL 'B' SV & 0.031 & 1.628 & 0.275 & 0.373 & 0.01706 \\
\hline THM.A & THOMSON NEWSPAPERS LTD. & 0.022 & 0.705 & 0.144 & 0.290 & 0.00411 \\
\hline $\mathrm{TIH}$ & TOROMONT INDUSTRIES LTD. & 0.010 & 0.451 & 0.183 & 0.093 & 0.00525 \\
\hline TIV & TIVERTON PETROLEUMS LTD. & 0.003 & 0.005 & 0.384 & 0.000 & 0.02090 \\
\hline TLG & CONS. THOMPSON-LUNDMARK & 0.006 & 0.923 & 0.522 & 0.051 & 0.04049 \\
\hline TMP & TRANS MOUNTAIN PIPE LINE & 0.015 & 0.421 & 0.219 & 0.059 & 0.00722 \\
\hline $\mathrm{TN}$ & TARRAGON OIL AND GAS LTD & 0.029 & 1.222 & 0.706 & 0.048 & 0.07410 \\
\hline TPN & TOTAL PETROLEUM NORTH AM & 0.015 & 1.253 & 0.253 & 0.293 & 0.01283 \\
\hline TRE & TERRATECH RESOURCES INC. & 0.005 & 1.425 & 0.452 & 0.144 & 0.03381 \\
\hline TRI & TRANSPACIFIC RESOURCES I & -0.019 & 0.417 & 0.465 & 0.013 & 0.03101 \\
\hline TRP & TRANSCANADA PIPELINES LT & 0.008 & 0.762 & 0.157 & 0.286 & 0.00487 \\
\hline TS.B & TORSTAR CORP. CL 'B' NV & 0.030 & 1.077 & 0.217 & 0.295 & 0.00943 \\
\hline TSP & TORONTO SUN PUBLISHING C & 0.026 & 0.364 & 0.228 & 0.041 & 0.00765 \\
\hline TXC & TEXACO CANADA INC. & 0.005 & 1.089 & 0.138 & 0.514 & 0.00554 \\
\hline UEL & UNION ENTERPRISES LTD. & 0.004 & 0.412 & 0.122 & 0.161 & 0.00253 \\
\hline UKH & UNITED KENO HILL MINES L & -0.001 & 1.756 & 0.378 & 0.268 & 0.02763 \\
\hline ULP & ULSTER PETROLEUMS LTD. J & 0.007 & 1.564 & 0.255 & 0.390 & 0.01504 \\
\hline UNC & UNITED CORPORATIONS LTD. & 0.033 & 0.786 & 0.209 & 0.193 & 0.00767 \\
\hline UNI.A & UNICORP CANADA CORP. CL & 0.010 & 1.156 & 0.238 & 0.286 & 0.01121 \\
\hline UNI.B & UNICORP CANADA CORP. CL & 0.008 & 1.275 & 0.282 & 0.257 & 0.01515 \\
\hline URP & UNITED REEF PETROLEUMS L & 0.037 & 2.086 & 0.717 & 0.191 & 6 \\
\hline
\end{tabular}


TABLE 5-34 (Continued)

\begin{tabular}{|c|c|c|c|c|c|c|}
\hline TICKER & $\underline{\text { NAME }}$ & $\begin{array}{c}\text { AVERAGE } \\
\text { TOTAL } \\
\text { RETURN }\end{array}$ & $\underline{\text { BETA }}$ & $\begin{array}{l}\text { SE } \\
\underline{\text { BETA }}\end{array}$ & $\begin{array}{c}\text { R- } \\
\text { SQUARED }\end{array}$ & $\begin{array}{c}\text { TOTAL } \\
\text { VARIANCE } \\
\text { (ER) } \\
\end{array}$ \\
\hline VAT & VARITY CORPORATION & 0.007 & 0.979 & 0.368 & 0.107 & 0.02148 \\
\hline VGT & NATIONAL VICTORIA \& GREY & 0.018 & 0.702 & 0.213 & 0.155 & 0.00762 \\
\hline VIP & VULCAN PACKAGING INC. & -0.009 & 0.801 & 0.526 & 0.039 & 0.02231 \\
\hline VSL & VS SERVICES LTD. & 0.018 & 0.174 & 0.196 & 0.013 & 0.00549 \\
\hline WAD & WADDY LAKE RESOURCES INC & -0.003 & 2.126 & 0.413 & 0.310 & 0.03503 \\
\hline WCC & WHIM CREEK CONSOLIDATED & 0.048 & 1.913 & 0.468 & 0.220 & 0.03982 \\
\hline WDS.A & WOODWARD'S LTD. CL 'A' & 0.010 & 0.572 & 0.264 & 0.074 & 0.01064 \\
\hline WEL & WARREN EXPLORATIONS LTD. & 0.024 & 2.182 & 0.482 & 0.258 & 0.04436 \\
\hline WET & WESTFORT PETROLEUMS LTD. & 0.036 & 0.885 & 0.846 & 0.018 & 0.10316 \\
\hline WFB & WAFERBOARD CORP. LTD. SV & 0.038 & 1.267 & 0.390 & 0.154 & 0.02445 \\
\hline WFD & WESTFIELD MINERALS LTD. & 0.018 & 1.941 & 0.277 & 0.455 & 0.01987 \\
\hline WFR & WHARF RESOURCES LTD. & 0.013 & 0.800 & 0.350 & 0.081 & 0.01891 \\
\hline WHN.A & WHONNOCK INDUSTRIES LTD. & 0.010 & 1.759 & 0.357 & 0.291 & 0.02551 \\
\hline WIL & WILCO MINING CO. LTD. J & 0.035 & 1.380 & 0.581 & 0.087 & 0.05234 \\
\hline WLR & WILANOUR RESOURCES LTD. & 0.040 & 2.142 & 0.673 & 0.146 & 0.07519 \\
\hline WLW & WELDWOOD OF CANADA LTD. & 0.021 & 0.757 & 0.214 & 0.175 & 0.00783 \\
\hline WMI & WESTMIN RESOURCES LTD. & 0.000 & 1.184 & 0.207 & 0.358 & 0.00941 \\
\hline WRR & WARRINGTON INC. & 0.008 & 0.884 & 0.311 & 0.121 & 0.01554 \\
\hline WTC & WESTCOAST TRANSMISSION C & 0.008 & 0.539 & 0.135 & 0.213 & 0.00327 \\
\hline
\end{tabular}




\section{TABLE 5-35}

\section{STATISTICAL CHARACTERISTICS OF THE TSE 300 SUBINDEXES FOR THE PERIOD FEBRUARY 1956 TO DECEMBER 1987 EMPLOYING MONTHLY DATA}

\begin{tabular}{|c|c|c|c|c|c|}
\hline Subindex & $\begin{array}{r}\text { Relative } \\
\text { Weight in } \\
\text { TSE 300 } \\
(\%)\end{array}$ & $\begin{array}{c}\text { Mean } \\
\text { Return }\end{array}$ & Minimum & Maximum & $\begin{array}{l}\text { Standard } \\
\text { Deviation }\end{array}$ \\
\hline Metals \& Minerals & 9.92 & 0.0056 & -0.3062 & 0.2374 & 0.0661 \\
\hline Gold \& Silver & 8.49 & 0.0135 & -0.3504 & 0.3968 & 0.0975 \\
\hline Oil \& Gas & 8.82 & 0.0077 & -0.2536 & 0.2906 & 0.0730 \\
\hline Paper \& Forest Products & 3.69 & 0.0059 & -0.2934 & 0.2259 & 0.0653 \\
\hline Consumer Products & 7.88 & 0.0070 & -0.2225 & 0.1748 & 0.0459 \\
\hline Industrial Products & 9.30 & 0.0056 & -0.2240 & 0.1563 & 0.0521 \\
\hline Real Estate \& Construction ${ }^{2}$ & 1.21 & 0.0129 & -0.2120 & 0.5685 & 0.0829 \\
\hline Transportation & 2.21 & 0.0094 & -0.2289 & 0.2062 & 0.0629 \\
\hline Pipelines & 3.03 & 0.0063 & -0.1699 & 0.1859 & 0.0550 \\
\hline Utilities & 11.44 & 0.0033 & -0.1101 & 0.1011 & 0.0326 \\
\hline Communications \& Media & 5.08 & 0.0111 & -0.2188 & 0.1935 & 0.0516 \\
\hline Merchandising & 4.55 & 0.0081 & -0.2103 & 0.2196 & 0.0514 \\
\hline Financial Services & 16.50 & 0.0056 & -0.1881 & 0.1772 & 0.0479 \\
\hline Management Co.'s & 7.87 & 0.0066 & -0.2202 & 0.2463 & 0.0613 \\
\hline TSE 300 & 100.00 & 0.0058 & -0.2263 & 0.1600 & 0.0460 \\
\hline
\end{tabular}

1. Subindex weights are market determined and therefore change monthly. These weights are for January 1988.

2. This index covers the period August 1961 to December 1987.

Source: The Toronto Stock Exchange 
TABLE 5-36

\section{BETAS AND RELATED CHARACTERISTICS OF THE TSE PRICE SUBINDEXES BASED ON THE 60 MONTHS ENDING DECEMBER 31, 1987}

\begin{tabular}{|c|c|c|c|c|c|}
\hline Subindex & $\begin{array}{c}\text { Mean } \\
\text { Return }\end{array}$ & Beta & $\begin{array}{c}\text { Standard } \\
\text { Error of } \\
\text { Beta } \\
\end{array}$ & $\underline{\mathbf{R}^{2}}$ & $\begin{array}{c}\text { Total } \\
\text { Variance }\end{array}$ \\
\hline Metals \& Minerals & 0.012 & 1.44 & 0.125 & 0.69 & 0.0079 \\
\hline Gold \& Silver & 0.018 & 1.45 & 0.253 & 0.36 & 0.0155 \\
\hline Oil \& Gas & 0.008 & 1.14 & 0.127 & 0.58 & 0.0060 \\
\hline Paper \& Forest Products & 0.023 & 1.27 & 0.109 & 0.69 & 0.0061 \\
\hline Consumer Products & 0.014 & 0.88 & 0.066 & 0.75 & 0.0027 \\
\hline Industrial Products & 0.008 & 1.07 & 0.071 & 0.79 & 0.0038 \\
\hline Real Estate \& Construction & 0.022 & 0.87 & 0.117 & 0.48 & 0.0041 \\
\hline Transportation & 0.023 & 1.08 & 0.122 & 0.57 & 0.0054 \\
\hline Pipelines & 0.010 & 0.72 & 0.091 & 0.52 & 0.0027 \\
\hline Utilities & 0.012 & 0.39 & 0.084 & 0.26 & 0.0015 \\
\hline Communications \& Media & 0.020 & 0.89 & 0.081 & 0.68 & 0.0031 \\
\hline Merchandising & 0.013 & 0.84 & 0.077 & 0.67 & 0.0028 \\
\hline Financial Services & 0.010 & 0.80 & 0.084 & 0.60 & 0.0028 \\
\hline Management Co's. & 0.022 & 1.15 & 0.077 & 0.79 & 0.0044 \\
\hline TSE 300 & 0.012 & 1.00 & 0.000 & 1.00 & 0.0026 \\
\hline
\end{tabular}

Source: The Toronto Stock Exchange 


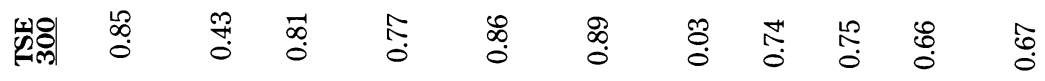

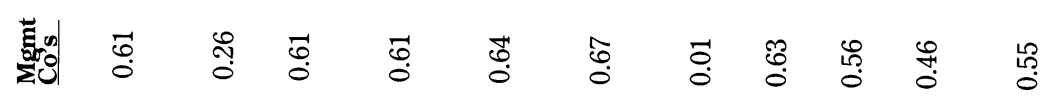

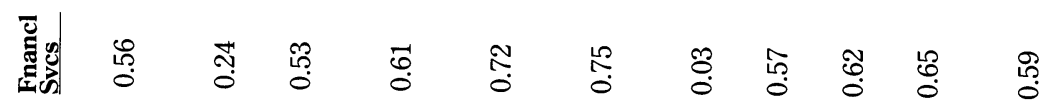

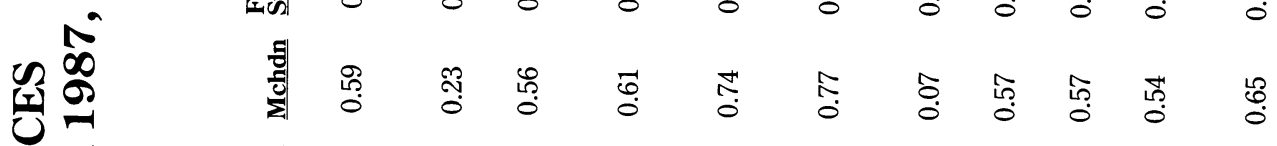

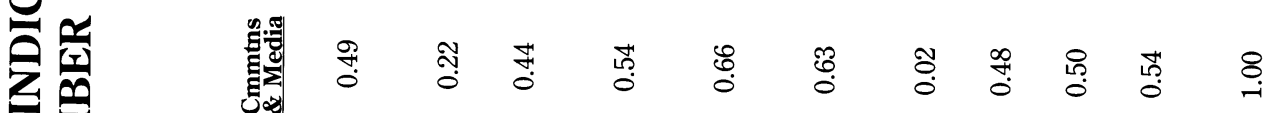

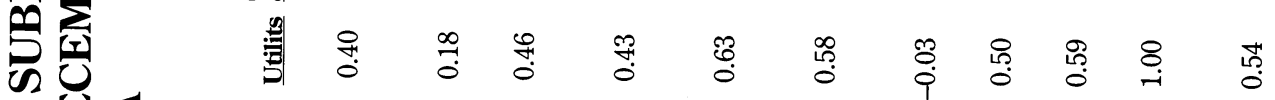

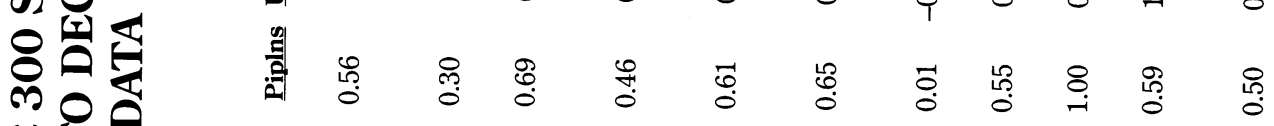

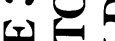

究这

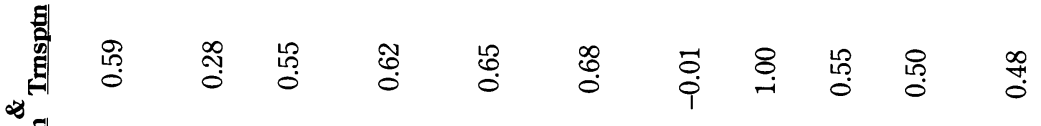

की

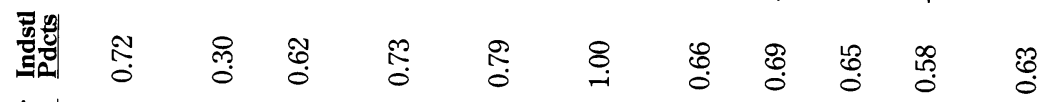

)

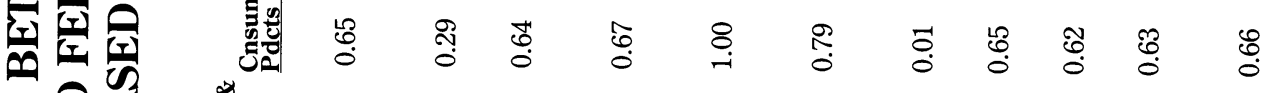

थै ิิ

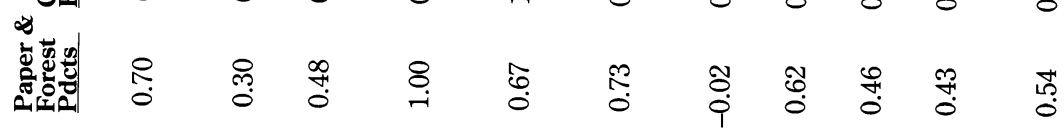

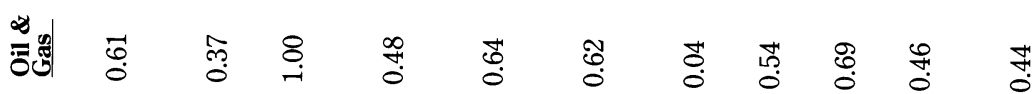

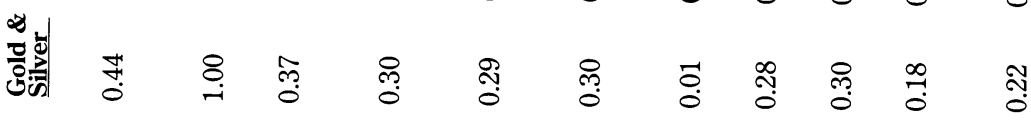

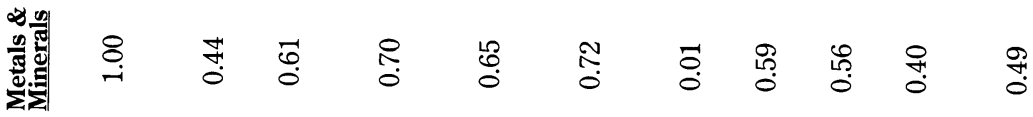

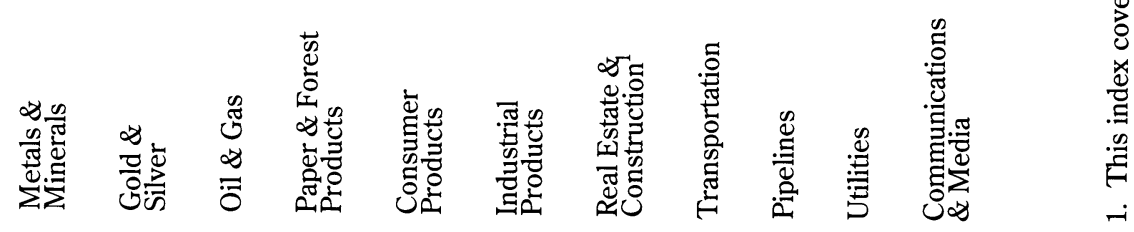




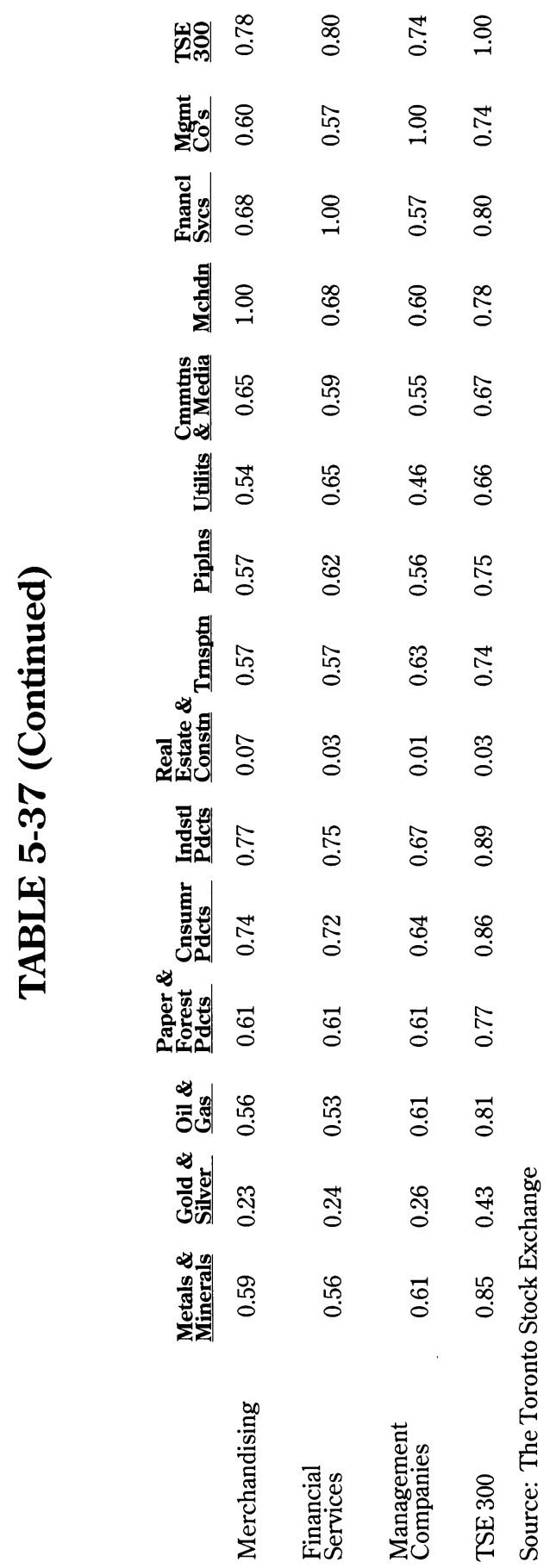


TABLE 5-38

\section{DAILY CLOSING BEHAVIOR OF THE TSE 300 PRICE INDEX AND THE TSE 300 TOTAL VALUE INDEX DURING OCTOBER 1987}

\begin{tabular}{rrrr} 
Day & $\begin{array}{c}\text { TSE 300 } \\
\text { Price Index }\end{array}$ & $\begin{array}{c}\text { TSE 300 } \\
\text { Total Value Index }\end{array}$ & $\begin{array}{r}\text { Percent } \\
\text { Change }\end{array}$ \\
\cline { 2 - 3 } 1 & 3898.03 & 5980.70 & -0.11 \\
2 & 3893.47 & 5973.70 & -0.12 \\
5 & 3918.08 & 6011.67 & 0.63 \\
6 & 3861.84 & 5925.69 & -1.44 \\
7 & 3838.36 & 5889.66 & -0.61 \\
8 & 3806.27 & 5840.70 & -0.84 \\
9 & 3781.22 & 5802.31 & -0.65 \\
13 & 3759.81 & 5769.46 & -0.57 \\
14 & 3719.47 & 5707.56 & -1.07 \\
15 & 3674.85 & 5639.09 & -1.20 \\
16 & 3598.58 & 5522.05 & -2.08 \\
19 & 3191.38 & 4899.36 & -11.32 \\
20 & 2977.31 & 4570.72 & -6.71 \\
21 & 3246.18 & 4983.49 & 9.03 \\
22 & 3107.59 & 4770.73 & -4.27 \\
23 & 3079.39 & 4727.44 & -0.91 \\
26 & 2846.49 & 4371.63 & -7.56 \\
27 & 2876.10 & 4417.35 & 1.04 \\
28 & 2837.79 & 4359.60 & -1.33 \\
29 & 2872.33 & 4412.71 & 1.22 \\
30 & 3019.27 & 4638.82 & 5.12
\end{tabular}

Source: The Toronto Stock Exchange 
TABLE 5-39

MONTHLY CLOSING BEHAVIOR OF THE TSE 300 PRICE INDEX AND THE TSE 300 TOTAL VALUE INDEX DURING 1987 AND THE FIRST TWO MONTHS OF 1988

$\begin{array}{lc}\text { Month } & \begin{array}{c}\text { TSE } \mathbf{3 0 0} \\ \text { Price Index }\end{array} \\ \text { Jan. } & 3348.85 \\ \text { Feb. } & 3498.93 \\ \text { Mar. } & 3739.47 \\ \text { Apr. } & 3716.74 \\ \text { May } & 3685.24 \\ \text { June } & 3740.19 \\ \text { July } & 4030.35 \\ \text { Aug. } & 3993.60 \\ \text { Sept. } & 3902.37 \\ \text { Oct. } & 3019.27 \\ \text { Nov. } & 2978.34 \\ \text { Dec. } & 3160.05 \\ \text { Jan.(1988) } & 3057.22 \\ \text { Feb.(1988) } & 3204.83\end{array}$

\begin{tabular}{c}
$\begin{array}{c}\text { TSE } \mathbf{3 0 0} \\
\text { Total Value Index }\end{array}$ \\
\hline 5049.63 \\
5283.82 \\
5666.89 \\
5638.25 \\
5602.05 \\
3705.34 \\
6156.23 \\
6109.49 \\
5987.36 \\
4638.82 \\
4589.86 \\
4889.82 \\
4737.55 \\
4976.47
\end{tabular}

Percent Change

9.22

4.48

6.87

$-0.61$

$-0.85$

1.49

7.75

$-0.91$

$-2.28$

$-22.63$

$-1.36$

6.11

$-3.25$

4.83

Source: The Toronto Stock Exchange 


\section{TABLE 5-40}

\section{PERCENT CHANGE OF THE TSE 300 SUBINDEXES DURING SELECTED DAYS OF OCTOBER 1987}

\section{Subindex}

Metals \& Minerals

Gold \& Silver

Oil \& Gas

Paper \& Forest Products

Consumer Products

Industrial Products

Real Estate \& Construction

Transportation

Pipelines

Utilities

Communications \& Media

Merchandising

Financial Services

Management Companies

TSE 300
Oct 14 Oct 15 Oct 16 Oct 19 Oct 20 Oct 21 Month

$\begin{array}{rrrrrrr}-0.09 & -2.12 & -2.91 & -14.83 & -14.34 & 7.87 & -30.62 \\ -1.74 & -0.21 & -1.35 & -8.82 & -19.97 & 14.76 & -35.04 \\ -0.54 & -2.14 & -1.68 & -12.58 & -6.73 & 11.62 & -21.70 \\ -1.79 & -1.77 & -2.89 & -14.47 & -4.85 & 4.23 & -29.34 \\ -1.97 & -1.84 & -2.54 & -10.61 & -5.10 & 7.22 & -22.25 \\ -2.35 & -1.23 & -3.67 & -11.08 & -3.67 & 8.74 & -22.40 \\ -0.13 & -1.80 & -1.17 & -9.16 & -9.51 & 12.03 & -20.15 \\ -0.20 & -4.24 & -4.44 & -17.17 & 4.76 & 11.60 & -22.89 \\ -1.67 & -1.80 & -3.45 & -9.42 & -5.93 & 9.55 & -16.90 \\ -0.58 & -0.21 & -0.14 & -7.15 & 2.80 & 6.29 & -7.21 \\ -2.83 & -0.12 & -2.76 & -12.79 & -6.13 & 13.03 & -21.88 \\ -2.26 & -1.77 & 0.65 & -10.72 & -5.31 & 9.39 & -21.03 \\ -0.27 & -0.12 & -1.79 & -8.25 & -4.74 & 7.26 & -18.81 \\ -1.10 & -1.52 & -2.59 & -17.20 & -2.76 & 8.69 & -22.02 \\ -1.07 & -1.20 & -2.08 & -11.32 & -6.71 & 9.03 & -22.63\end{array}$

Source: The Toronto Stock Exchange 


\section{APPENDIXES}

The purpose of these appendixes is to outline and give examples of all the major computations used in creating the results seen in the body of the paper.

\section{Appendix A - Calculation of Treasury Bill Returns}

The monthly rate of return on Treasury bills was computed as follows:

$$
\mathrm{R}_{\mathrm{t}}=\frac{\mathrm{P}_{\mathrm{t}}-\mathrm{P}_{\mathrm{t}-1}}{\mathrm{P}_{\mathrm{t}-1}}
$$

where

$\mathrm{P}_{\mathrm{t}} \quad=$ price at the end of the period $\mathrm{t}$, and

$\mathrm{P}_{\mathrm{t}-1}=$ price at the end of period $\mathrm{t}-1$.

The equation for the price of a 91-day Treasury bill as used by money market dealers is

$$
\mathrm{P}=\frac{100}{100+\frac{(\mathrm{r})(91)}{365}}
$$

where

$\mathrm{r} \quad=$ the yield to maturity on an annual basis (the data series supplied by Statistics Canada: Cansim B14007).

This equation allowed us to compute the price of a 91-day Treasury bill at time $t-1$ and of a 61-day Treasury bill 30 days later at a time t: 


$$
\mathrm{P}_{\mathrm{t}-1}=\frac{100}{100+\frac{\mathrm{t}-1(91)}{365}}
$$

and

$$
P_{t}=\frac{100}{100+\frac{r_{t-1}(91)}{365}}
$$

Employing (A1), (A3), and (A4) we were able to compute a time series of monthly ex post returns which assumed the purchase of a 91-day Treasury bill and its resale 30 days later, when it had 61 remaining days to maturity.

\section{Appendix B - Calculation of Long-Term \\ Government of Canada Bond Returns}

The monthly bond return for period $t$ for long-term Government of Canada bonds only was computed as follows:

$$
R_{t}=\frac{P_{t}-P_{t-1}+I_{t}}{P_{t-1}}
$$

where

$\mathrm{R}_{\mathrm{t}} \quad=$ bond return for month $\mathrm{t}$,

$\mathrm{P}_{\mathrm{t}} \quad=$ price of bond at end of period $\mathrm{t}$, 
$\mathrm{P}_{\mathrm{t}-1}=$ price of bond at the end of period $\mathrm{t}-1$ (always assumed to be 100), and

It $\quad=$ interest received during period $\mathrm{t}$.

The raw data from which returns were computed are a series of yields to maturity $\left(\mathrm{Y}_{\mathrm{t}}\right)$ for each month t expressed, for example, as 9.05. Assuming that the bonds are compounded semiannually and that they are repurchased at the beginning of each month at 100 , the price at the end of a given month $t$ is computed as follows:

$$
\begin{aligned}
\mathrm{P}_{\mathrm{t}}= & \frac{\mathrm{Y}_{\mathrm{t}-1 / 2}}{\left(1+\frac{\mathrm{Y}_{\mathrm{t}} / 100}{2}\right)^{1}}+\frac{\mathrm{Y}_{\mathrm{t}-1 / 2}}{\left(1+\frac{\mathrm{Y}_{\mathrm{t}} / 100}{2}\right)^{2}}+\ldots+\frac{\mathrm{Y}_{\mathrm{t}-1 / 2}}{\left(1+\frac{\mathrm{Y}_{\mathrm{t}} / 100}{2}\right)^{2 \mathrm{M}}} \\
& +\frac{100}{\left(1+\frac{\mathrm{Y}_{\mathrm{t}} / 100}{2}\right)^{2 \mathrm{M}}}
\end{aligned}
$$

where

$\mathrm{Y}_{\mathrm{t}} \quad=$ yield obtained from the Government of Canada bond yield series for period t (e.g., 9.05)

$\mathrm{Y}_{\mathrm{t}-1}=$ yield obtained from the Government of Canada bond yield series for period $t-1$

$\mathrm{M} \quad$ = assumed average term to maturity. Calculated long-term Government of Canada bond returns in this study assume seventeen years.

The interest earned ( $\mathrm{I}_{\mathrm{t}}$ ) on the bond for period $\mathrm{t}$ is calculated by assuming that bonds are purchased at the beginning of the period at par and that, therefore, the coupon is equal to the stated yield to maturity for the period. 
Thus,

$$
I_{t}=\frac{Y_{t-1}}{12}
$$

\section{Appendix C - Calculation of Individual Stock Returns}

In this section the method for computing returns on individual securities is discussed. The simplest case occurs where there are no dividends and no changes in the number of shares outstanding. Complications arise due to such events as stock splits, cash dividends and rights issues. Our method of handling these types of events is discussed and illustrated.

The Simplest Case. In the simplest possible case where a stock pays no dividends and where no share capital related events such as stock splits have occurred, the return for a month is:

$$
R_{t}=\frac{P_{t}-P_{t-1}}{P_{t-1}}
$$

where

$\mathrm{R}_{\mathrm{t}}=$ return for period $\mathrm{t}$,

$\mathrm{P}_{\mathrm{t}}=$ price per share at the end of period $t$, and

$\mathrm{P}_{\mathrm{t}-1}=$ price per share at the end of period $\mathrm{t}-1$.

Example. Suppose $\mathrm{ABC}$ Co. had a stock price at the end of January of $\$ 12$ and at the end of February of $\$ 14$. There were no changes in shares outstanding during the month. The rate of return for the month is computed using equation $\mathrm{C} 1$ as follows: 


$$
\begin{aligned}
R_{t} & =\frac{14-12}{12} \\
& =0.1667
\end{aligned}
$$

Stock Splits. If there is a stock split during a period, a split factor is recorded indicating the ratio of shares outstanding after the split to shares outstanding before the split. The rate of return for the stock during the split period is computed by adjusting the post split price by the split factor as follows:

$$
R_{t}=\frac{\left(P_{t}\right)\left(S_{t}\right)-P_{t-1}}{P_{t-1}}
$$

where

$\mathrm{S}_{\mathrm{t}} \quad=$ split factor for month $\mathrm{t}$

$\mathrm{R}_{\mathrm{t}}, \mathrm{P}_{\mathrm{t}}, \mathrm{P}_{\mathrm{t}-1}=$ as previously defined.

Example. BCD Co. shares were priced at $\$ 15$ at the end of January and $\$ 10$ at the end of February. There was a two-for-one split during February. The firm paid no dividends during the period. Using equation $\mathrm{C} 2$ the rate of return was

$$
\begin{aligned}
\mathrm{R}_{\mathrm{t}}=\frac{(10)(2)-15}{15} \\
=0.3333
\end{aligned}
$$

Cash Dividends. Dividends are normally declared on one date (the "declaration date") to investors of record on a second date (the "record date") payable on a third date (the "payment date"). The stock exchange also names a particular date during and after which the purchaser of the 
share is not entitled to the dividend. By tradition in Canada, this date (called the "ex-dividend date" is four business days before the dividend record date. The days preceding the ex-dividend date are called "cum-dividend dates" meaning the purchaser is entitled to the dividend.

The timing of these various dates has implications for the computation of rates of return since the market price of the stock typically falls by the amount of the dividend on the ex-dividend date. In order to take this phenomenon into account, it is appropriate to treat dividends as if they are paid on the ex-dividend date rather than on the payment date. Thus the return for a given month is computed as follows:

$$
R_{t}=\frac{P_{t}-P_{t-1}+D_{t}}{P_{t-1}}
$$

where $D_{t}=$ the dollar amount of the dividend to be paid if the ex-dividend date occurs during period $t$, and all other variables as previously defined.

Example. CDE Co. shares traded in the market at $\$ 20$ on December 31 and at $\$ 24$ on January 31 . On January 15 the company declared a $\$ 1$ dividend to shareholders of record January 25 and payable February 5. The ex-dividend date was January 21. Before that date, the shares were trading cum-dividend.

The return for the month of January employing C3 is

$$
\begin{aligned}
R_{t} & =\frac{24-20+1}{20} \\
& =0.25
\end{aligned}
$$

Simultaneous Splits and Cash Dividends. Sometimes a company pays a cash dividend and also splits the 
stock in the same month. As usual, the key computational task which arises under these conditions is to identify the change in wealth over the month attributable to the owner of a share at the beginning of the month. This means that the dividend paid and the end of period stock price must be matched with the beginning of period shares outstanding.

The stock split is accommodated through a split factor as discussed earlier. The cash dividend is accommodated by adjusting the dividend (when appropriate) by a split factor as well. In general, if the split occurs before the ex-dividend date, the dividend is adjusted for the split factor, because all split shares receive the declared dividend. If the split occurs on or after the ex-dividend date, no adjustment is made to the declared dividend.

Symbolically: if the effective split date occurs before the ex-dividend date:

$$
R_{t}=\frac{\left(P_{t}\right)\left(S_{t}\right)-P_{t-1}+\left(D_{t}\right)\left(S_{t}\right)}{P_{t-1}}
$$

if the effective split date occurs on or after the ex-dividend date:

$$
R_{t}=\frac{\left(P_{t}\right)\left(S_{t}\right)-P_{t-1}+\left(D_{t}\right)}{P_{t-1}}
$$

Example. DEF Co. shares were trading in the market on December 31 at $\$ 20$. On January 15, the company declared a $\$ 1$ dividend to shareholders of record January 25 and payable February 5. The ex-dividend date was January 21. The stock price was $\$ 11$ on January 31. If a 2 -for-1 split was announced effective any time during the period January 21-31 inclusive, the rate of return would be: 


$$
\begin{aligned}
R_{t} & =\frac{(11)(2)-20+1}{20} \\
& =0.15
\end{aligned}
$$

If a 2-for-1 split was announced effective any time during the period January 1-20 inclusive, the rate of return would be:

$$
\begin{aligned}
\mathrm{R}_{\mathrm{t}} & =\frac{(11)(2)-20+(1)(2)}{20} \\
& =0.20
\end{aligned}
$$

Stock Dividends. Stock dividends may be paid either in the same security that the dividend was issued for, or in a different security, which may be a different issue or the stock belonging to another company. Stock dividends are most frequently declared in the form of a cash equivalent such as 10 cents per share, but they are sometimes expressed as a percent such as 4 percent. When the cash equivalent was provided it was simply recorded in the same fashion as a cash dividend. When the stock dividend was stated as a percent of the shares outstanding and was paid in the same security for which it was issued, a "quasi split factor" is used to calculate the return.

$$
\mathrm{R}_{\mathrm{t}}=\frac{\left(\mathrm{P}_{\mathrm{t}}\right)\left(\mathrm{QS}_{\mathrm{t}}\right)-\mathrm{P}_{\mathrm{t}-1}}{\mathrm{P}_{\mathrm{t}-1}}
$$

where

$\mathrm{QS}_{\mathrm{t}} \quad=$ quasi-split factor for month $\mathrm{t}$

$\mathrm{R}_{\mathrm{t}}, \mathrm{P}_{\mathrm{t}}, \mathrm{P}_{\mathrm{t}-1}=$ as previously defined

Example. EFG Co. common shares were trading in the market at $\$ 80$ on December 31 and $\$ 79$ on January 31. On 
January 15 , the company declared a 2 percent stock dividend on its common shares, payable on February 15. The ex-dividend date is January 21 . The rate of return employing equation $\mathrm{C} 6$ is:

$$
\begin{aligned}
R_{t} & =\frac{(79)(1.02)-80}{80} \\
& =0.00725
\end{aligned}
$$

If a stock dividend is paid in another security, or class of security, an equivalent cash value of the dividend is obtained, and the dividend is then treated as an ordinary cash dividend. The equivalent cash value is defined as the opening market value of the security on the ex-dividend date.

Example. FGH Co. common shares were trading at $\$ 25$ on December 31 and $\$ 28$ on January 31. On January 15, FGH announced a dividend of one Class A Preferred share for each 20 common shares held, payable on February 10. The ex-dividend date was January 21 . On that date the Class A Preferred shares opened at $\$ 10$.

The equivalent cash value of the stock dividend is:

$(10)(1 / 20)=\$ 0.50$ per common share

$$
\begin{aligned}
R_{t} & =\frac{28-25+.50}{25} \\
& =0.14
\end{aligned}
$$

Rights Offerings. Rather than offering a cash or stock dividend, some companies give their shareholders stock 
rights, which may or may not be exercised. These rights are treated just like cash dividends and the cash equivalent is the price at which the rights are trading on the ex-dividend date.

\section{Appendix D - Calculation of Value-Weighted Total Return}

Once individual security returns are determined they must be combined in some way to determine the overall market rate of return for each period. The most widely accepted method of achieving this result is to compute a value-weighted rate of return. A value-weighted return of all available stocks was chosen for most purposes in this study because it most accurately reflects the change in total wealth realized by all market investors as a group.

The Simplest Case. The simplest possible case occurs where the stocks involved pay no dividends and where there are no share capital related events such as stock splits. In this case the total return for a period is:

$$
\mathrm{RT}_{\mathrm{t}, \mathrm{t}}=\sum_{\mathrm{i}=1}^{\mathrm{N}}\left[\frac{\mathrm{V}_{\mathrm{i}, \mathrm{t}-1}}{\underset{\mathrm{i}=1}{\mathrm{~N}} \mathrm{~V}_{\mathrm{i}, \mathrm{t}-1}} \mathrm{R}_{\mathrm{i}, \mathrm{t}}\right]
$$

where

$\mathrm{RT}_{\mathrm{T}, \mathrm{t}}=$ total return for all shares during period $\mathrm{t}$,

$\mathrm{V}_{\mathrm{i}, \mathrm{t}-1}=$ total value of all shares outstanding for security $i$ at the end of period $t-1$, 


$$
\begin{aligned}
& \mathrm{R}_{\mathrm{i}, \mathrm{t}}=\text { rate of return for security } \mathrm{i} \text { for period } \mathrm{t} \text {, and } \\
& \mathrm{V}_{\mathrm{i}, \mathrm{t}-1}=\mathrm{O}_{\mathrm{i}, \mathrm{t}-\mathrm{1}} \mathrm{P}_{\mathrm{i}, \mathrm{t}-\mathrm{t}}
\end{aligned}
$$

and where

$\mathrm{O}_{\mathrm{i}, \mathrm{t}-1}=$ number of shares of security $\mathrm{i}$ outstanding at the end of period $t-1$,

$\mathrm{P}_{\mathrm{i}, \mathrm{t}-1}=$ price per share at the end of period $\mathrm{t}-1$,

$\mathrm{N}=$ number of securities with no missing data for $\mathrm{t}$ and $\mathrm{t}-1$.

Example. Suppose the following information is available on two firms which pay no dividends: HIJ Co. and IJK Co.

HIJ Co.

shares outstanding

stock price

total value

IK Co.

shares outstanding

stock price

total value
January $31 \quad$ February 28

6

$\$ 15$

90

6

$\$ 20$

120

$\begin{array}{rr}5 & 5 \\ \$ 12 & \$ 14 \\ 60 & 70\end{array}$

$$
\begin{aligned}
& \mathrm{R}_{\mathrm{HIJ}}=\frac{20-15}{15}=0.33 \\
& \mathrm{R}_{\mathrm{JJ}}=\frac{14-12}{12}=0.167
\end{aligned}
$$




$$
\begin{aligned}
\text { RTotal } & =\frac{(90)(.333)+(60)(.167)}{150} \\
& =0.267
\end{aligned}
$$

Notice that this method of calculating total returns is the equivalent of determining the percentage increase in total wealth over the period for an investor who owned all of the shares in all of the companies.

$$
\begin{array}{ll}
\text { wealth at } t-1 & 190+60=150 \\
\text { wealth at } t & 120+70=190
\end{array}
$$

percent increase in wealth $\frac{190-150}{150}=0.267$

StockSplits. Stock splits are taken into account through the use of split factors in computing individual stock returns. This computation was expressed earlier as equation $\mathrm{C} 2$.

Example. Suppose the following information is available on two firms which pay no dividends: JKL Co. and KLM Co. JKL Co. has split two-for one.

$\begin{array}{lcc}\text { JKL Co. } & \text { January 31 } & \text { February 28 } \\ \text { shares outstanding } & 6 & 12 \\ \text { stock price } & \$ 15 & \$ 10 \\ \text { total value } & 90 & 120 \\ & & \\ \text { KLM Co. } & 5 & 5 \\ \text { shares outstanding } & \$ 12 & \$ 14 \\ \text { stock price } & 60 & 70 \\ \text { total value } & & \end{array}$




$$
\begin{aligned}
\mathrm{RJKL} & =\frac{(10)(2)-15}{15}=0.333 \\
\mathrm{RKLM} & =\frac{(14)-(12)}{12}=0.167 \\
\mathrm{R}_{\text {Total }} & =\frac{(90)(.333)+(60)(.167)}{150} \\
& =0.267
\end{aligned}
$$

Cash Dividends. Cash dividends are taken into account in the calculation of individual security returns, as was demonstrated earlier in equation C3. However, an issue arises regarding the reinvestment of cash dividends. Our calculations of market rates of return assume that all cash dividends are received during the period in which the ex-dividend date falls and are reinvested in the stock market at the beginning of the next period. Dividends are allocated to outstanding shares in proportion to the total value of the shares outstanding at the end of the previous period. An example will clarify these assumptions.

Example. Let us assume the following information on two companies LMN and MNO.

\section{$\underline{\mathrm{LMN}}$ \\ shares outstanding \\ price/share \\ dividend/share \\ total value of shares \\ return (using C3)}

\begin{tabular}{rrr}
\multicolumn{3}{c}{ period ending } \\
$\mathrm{t}-1$ & $\frac{\mathrm{t}}{\mathrm{n}}$ & $\underline{\mathrm{t}+1}$ \\
8 & 8 & 8 \\
16 & 20 & 22 \\
- & 2 & - \\
128 & 160 & 176 \\
& 0.375 & 0.10
\end{tabular}


MNO

shares outstanding

price/share

dividend/share

total value of shares

return

Total Wealth (not

$\begin{array}{rrr}10 & 10 & 10 \\ 8 & 12 & 13 \\ - & - & - \\ 80 & 120 & 130 \\ & 0.5000 & 0.083\end{array}$

including dividends)

208

period ending

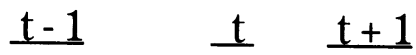

Total Return (using C6)

$280 \quad 306$

$0.423 \quad 0.093$

Notice that if one computes the total wealth at the end of $\mathrm{t}+1$ by multiplying the initial wealth at $\mathrm{t}-1$ by the returns for each of the next two periods, the result is

$$
(208)(1.423)(1.093)=\$ 323.50
$$

which is greater than the total value of all shares outstanding at the end of $\mathrm{t}-$ namely $\$ 306$. The difference of $\$ 17.50$ is the result of receiving $\$ 16$ in dividends on company LMN shares and reinvesting those funds for period $t+1$ at an average return of 0.093 . This graphically illustrates the point that the method of return calculation employed in this study assumes that all dividends are to be reinvested proportionately in the shares in existence at the end of the dividend period.

New Classes of Shares. In a number of cases, a given class of shares was subdivided into two new classes of shares or two classes of shares were exchanged for one new class of shares. All of these occurrences were identified within the database, and wherever possible the common 
voting shares were kept as a continuous series with the most recent ticker symbol.

Commonly a given class of shares was replaced by two interchangeable classes of shares. In this case the rate of return series was based on the price of the regular common share (usually identified by the TSE) and the shares outstanding was the sum of the shares of both issues.

When a given class of shares was replaced by two non-interchangeable classes of shares, price data in the month of the switch was treated as missing and two new series were created. The class that was judged closest in nature to the common was considered part of the original return series for purposes of generating a long series of return data for a given firm.

\section{Appendix E - Calculation of the Moving Standard} Deviation

A moving 12-month standard deviation of returns was computed as follows:

$$
\overline{\mathrm{R}}_{\mathrm{M}}=\frac{1}{12} \sum_{\mathrm{t}=\mathrm{M}-11}^{\mathrm{t}=\mathrm{M}} \mathrm{R}_{\mathrm{t}}
$$

where

$\mathrm{RM}_{\mathrm{M}+11}=$ arithmetic average of monthly returns over the twelve-month period beginning in period M-11 and ending in period $\mathrm{M}$,

$\mathrm{R}_{\mathrm{t}} \quad=$ return for month $\mathrm{t}$

$$
\operatorname{Std} \operatorname{Dev}(R)=\frac{\sum_{t=M-11}^{t=M}\left(R_{t}-\bar{R}_{M}\right)^{2}}{11} ; \quad M=12, \ldots, 408
$$


where Std Dev $\left(\mathrm{R}_{\mathrm{M}}\right)=$ moving average twelve-month standard deviation.

As $\mathrm{M}$ is incremented by one month, a more recent observation is added and the oldest observation is dropped.

\section{Appendix F - Calculation of Real Returns}

Monthly real return data were derived from monthly nominal return data as follows:

$$
\begin{aligned}
& \text { Let } \mathrm{NR}_{\mathrm{t}}=\text { nominal return in month } \mathrm{t} \text {, } \\
& \text { It }=\text { inflation rate in month } \mathrm{t} \text { based on the } \\
& \text { Consumer Price Index, and } \\
& \mathrm{RR}_{\mathrm{t}} \quad=\text { real return for month } \mathrm{t} \text {. } \\
& \mathrm{RR}_{\mathrm{t}}=\frac{1+\mathrm{NR}_{\mathrm{t}}}{1+\mathrm{I}_{\mathrm{t}}}-1
\end{aligned}
$$

Then

\section{Appendix G - Data Sources}

Data employed in this study were obtained from:

The Bank of Canada, Review, various issues.

The Center for Research on Security Prices, Data

Tape, 1987 version

The Financial Post Corporation Service

Financial Post Cards

Dividend Record

Ibbotson Associates, Stocks, Bonds, Bills and Inflation:

Yearbook. Chicago, IL.: Ibbotson Associates, various issues. 
Ibbotson, Roger G. and Rex A. Sinquefield, Stocks, Bonds, Bills and Inflation: The Past and The Future.

Charlottesville, Va.: The Research Foundation of the Institute of Chartered Financial Analysts, 1982 .

McLeod, Young, Weir Limited, Yield Price and Value

Indices, Toronto, February 15, 1987.

Montreal Exchange, Monthly Review, selected issues.

Statistics Canada - Cansim Data Base

Consumer Price Index

Exchange Rates

(D130000)

Government of Canada

Bonds Yields

(B3400)

Treasury Bill Yields

(B14013)

(B14007)

Toronto Stock Exchange, Review, selected issues.

TSE/Western Data Base, March 1987 version. 


\section{REFERENCES}

[1] Amoako-Adu, Bem. "The Canadian Tax Reform and Its Effect on Stock Prices: A Note." The Journal of Finance (December 1983): 1969-1975.

[2] Berger, Angel, John J. McConnell, and Gary G. Schlarbaum. "The Turn of the Year in Canada." The Journal of Finance (March 1984): 185-192.

[3] Booth, L.D. and D.J. Johnston. "The Ex-Dividend Day Behavior of Canadian Stock Prices: Tax Changes and Clientele Effects." The Journal of Finance (June 1984):0457-476.

[4] Canadian Shareholders: Their Profile and Attitudes. Toronto, Ontario: The Toronto Stock Exchange, 1986.

[5] Fama, Eugene F. Foundations of Finance. New York, N.Y.: Basic Books, 1976.

[6] Fama, Eugene F. "Stock Returns, Real Activity, Inflation and Money." American Economic Review (September 1981): 545-565.

[7] Fowler, David J., C. Harvey Rorke, and Vijay Jog. "Thin Trading and Beta Estimation Problems on The Toronto Stock Exchange." Journal of Business Administration (Fall 1980): 77-90.

[8] Fullerton, Douglas H. The Bond Market in Canada. Toronto, Ontario: The Carswell Company Ltd., 1962.

[9] Gilson, Stuart C. The Inflation-Adjusted Rates of Returns of Corporate Debt and Equity: 1966-1980. Ottawa, Ontario: Bank of Canada, 1984.

[10] "Government of Canada Treasury Bills." Bank of Canada Review (May 1972): 3-13. 
[11] Hatch, James E. and Michael Robinson. Investment Management in Canada, 2nd Ed. Toronto, Ontario: Prentice-Hall Canada, Inc., 1988.

[12] Hatch, James E. and Robert W. White. Canadian Stocks, Bonds, Bills, and Inflation: 1950-1983. Charlottesville, Virginia: Financial Analysts Research Foundation, 1985.

[13] Ibbotson, Roger G., Richard C. Carr, and Anthony W. Robinson. "International Equity and Bond Returns," Financial Analysts Journal, (July/August 1982): 61-83.

[14] Ibbotson, Roger G. and Rex A. Sinquefield. Stocks, Bonds, Bills and Inflation: The Past and The Future. Charlottesville, Virginia: The Financial Analysts Research Foundation, 1982.

[15] Khoury, Nabil T. "Historical Return Distribution of Investments in Canadian Bonds." Journal of Business Administration (Fall 1980): 119-135.

[16] Lakonishok, Joseff and Theo Vermaelen. "Tax Reform and Ex-Dividend Day Behavior.” The Journal of Finance (September 1983): 1157-1179.

[17] Lorie, James H. and Mary T. Hamilton. The Stock Market: Theories and Evidence. Homewood, Illinois: Richard D. Irwin, 1973.

[18] McCallum, John S. "The Canadian Conversion Loan: A Remembrance," Journal of Bank Research (Spring 1980): 54-56.

[19] Mishkin, Frederic S. "The Real Interest Rate: A Multi-Country Empirical Study." Canadian Journal of Economics (May 1984): 283-311.

[20] Morgan, I.G. "Dividends and Stock Price Behavior in Canada." Journal of Business Administration (Fall 1980): 91-106. 
[21] Morin, Roger A. "Market Line Theory and The Canadian Equity Market." Journal of Business Administration (Fall 1980): 57-76.

[22] Officer, R. R. "The Variability of The Market Factor of The New York Stock Exchange." Journal of Business (July 1973): 434-453.

[23] "Overnight Financing in Canada: Special Call Loans." Bank of Canada Review (May 1982): 3-11.

[24] Sarpkaya, S. The Money Market in Canada, 3rd ed. Toronto, Ontario: $\mathrm{CCH}$ Canadian Ltd. 1984.

[25] R.G. Ibbotson Associates. Stocks, Bonds, Bills and Inflation: 1986 Yearbook. Chicago, Illinois: R. G. Ibbotson Associates, 1986.

[26] The Center For Research on Security Prices. The CRSP Stock File User's Guide, Chicago, Illinois: University of Chicago.

[27] The Canadian Securities Course 1985-86. Toronto, Ontario: The Canadian Securities Institute, 1986.

[28] “The Corporate Short-Term Paper Market." Bank of Canada Review (September 1976): 3-16.

[29] "The Financing of Provincial and Municipal Governments and Their Enterprises." Bank of Canada Review (October 1972): 3-20.

[30] "The Financing of Provincial Governments and Their Enterprises." Bank of Canada Review (January 1981): 3-11.

[31] Tinic, Seha M. and Richard R. West. "Marketability of Common Stocks in Canada and the U.S.A.: A Comparison of Agent Versus Dealer Dominated Markets." The Journal of Finance (June 1974): 729-746. 
[32] Todd, John D. Price Competitions in the Canadian Securities Industry: A Test Case of Deregulation. Discussion Paper Series. Toronto, Ontario: Ontario Economic Council, 1983.

[33] White Paper on Tax Reform 1987. Ottawa, Ontario: Department of Finance, June 18, 1987. 